\title{
Mineral chemistry of magnetite from magnetite- apatite mineralization and their host rocks: \\ Examples from Kiruna, Sweden \\ and El Laco, Chile
}

\author{
Shannon G. Broughm
}

A thesis submitted to the Department of Earth Sciences in partial fulfillment of the requirements for the degree of Master of Science.

Memorial University of Newfoundland 
Magnetite-apatite deposits, sometimes referred to as Kiruna-type deposits, are major producers of iron ore that dominantly consist of the mineral magnetite (nominally $\left.\left[\mathrm{Fe}^{2+} \mathrm{Fe}^{3+}{ }_{2}\right] \mathrm{O}_{4}\right)$. It remains unclear whether magnetite-apatite deposits are of hydrothermal or magmatic origin, or a combination of those two processes, and this has been a subject of debate for over a century. Magnetite is sensitive to the physicochemical conditions in which it crystallizes (such as element availability, temperature, $\mathrm{pH}, f \mathrm{O}_{2}$, and $f \mathrm{~S}_{2}$ ) and may contain distinct trace element concentrations depending on the growing environment. These properties make magnetite potentially a useful geochemical indicator for understanding the genesis of magnetite-apatite mineralization.

The samples used in this study are from precisely known geographic locations and geologic environments in the world class districts of Kiruna and the Atacama Desert and their associated, sometimes hydrothermally altered, host rocks. Trace element analyses results of magnetite from the Kiruna area in the Norrbotten region of northern Sweden, and the E1 Laco and Láscar volcanoes in the Atacama Desert of northeastern Chile, were evaluated using mineral deposit-type and magmatic vs. hydrothermally derived magnetite discrimination diagrams.

The objectives of this study are to critically evaluate the practical use and limitations of these discrimination diagrams with the goal of determining if the trace element chemistry of magnetite can be used to resolve if magnetite-apatite deposits form in a hydrothermal or magmatic environment, or a combination of those two processes.

The results of this study reveal that the magnetite from Kiruna have relatively low trace element concentrations and are homogeneous. There is little chemical variation 
between the ore, the hydrothermally altered host rocks, and related igneous intrusives from Kiruna, which may be a result of pervasive post-formation alteration due to extensive metasomatism and later greenschist facies metamorphism that has affected the region. Distinct chemical variations do exist, however, in the magnetite at El Laco between magnetite from the Laco Sur magnetite-apatite ore and host andesite, and a dacite sample from the nearby Láscar volcano. Accessory magnetite from the host andesite and Láscar dacite volcanic rocks have relatively high trace element concentrations, typical of magnetite crystallizing from a melt and; with overall trace element concentrations higher than the magnetite-apatite ore, or the Kiruna magnetites. The Laco Sur ore magnetite has low overall low trace element concentrations and displays growth zoning defined by incompatible elements $(\mathrm{Si}, \mathrm{Ca})$, compatible elements ( $\mathrm{Mg}, \mathrm{Al}$, and $\mathrm{Mn}$ ), LILE ( $\mathrm{Sr}$ ) and HFSE (Y, Nb, Ce and Th) with each element displaying similar geochemical trends. While the trace element concentrations of the ore magnetite at Laco Sur has cores that are enriched in incompatible element; similar to magnetite that is known to have formed from hydrothermal fluids (such as magnetite from iron-rich skarns), the trace element zoning patterns suggests that the magnetite crystallized from a volatile-rich iron-oxide melt. 


\section{Acknowledgments}

I would like to thank those who funded this research, the Natural Sciences and Engineering Research Council of Canada (NSERC) discovery grant to John M. Hanchar. The contribution of Fernando Tornos has been funded by the project SEIDI 2014 CGL2014-55949-R.

Thanks to Luossavaara-Kiirunavaara Aktiebolag (LKAB) and Compañía Minera del Pacífico (CMP) for help in logistics, and permission to sample and granting access to the mine sites.

I want to express my gratitude to my supervisor John M. Hanchar for giving me the opportunity to pursue this research and for providing valued feedback throughout.

A special thanks goes to Fernando Tornos and Anne Westhues who both provided me with critical feedback throughout my research, especially during the compilation of my manuscript. Thank you to Steve Piercey for being on my committee during this project, allowing me to use the petrographic microscope in his research lab, and for having good taste in music.

Thanks to Samuel Attersley for his magnetite data from El Laco, which made this study vastly more interesting.

Many thanks to all my friends in Newfoundland (especially my office mate and best friend Sarah Turner) who provided me with emotional support, and food, during trying times while pursuing my M.Sc. degree.

Thank you to my family for believing in my success and financial contributions when ends could not be met. 
Table of Contents

\begin{tabular}{lr}
\hline Abstract & ii \\
Acknowledgments & iv \\
\hline Chapter 1: Introduction to the Research & 6 \\
\hline Introduction & 6 \\
Research Statement & 7 \\
Research Questions & 9 \\
Project Overview & 9 \\
Co-authorship Statement & 10
\end{tabular}

Chapter 2:

Mineral chemistry of magnetite from magnetite-apatite mineralization and their host rocks: Examples from Kiruna, Sweden and El Laco, Chile 13

$\begin{array}{ll}\text { Abstract } & 14\end{array}$

Introduction 15

Geologic background $\quad 21$

Kiruna geology and magnetite-apatite ores 21

El Laco geology and magnetite-apatite ores 24

Láscar volcano 25

Analytical methods $\quad 25$

Sample selection and preparation $\quad 25$

$\begin{array}{ll}\text { EPMA analyses } & 27\end{array}$

X-ray maps 28

LA-ICPMS analyses 28

$\begin{array}{ll}\text { Results } & 30\end{array}$

El Laco magnetite textures and associated minerals 34

Kiruna magnetite X-ray maps 38

El Laco magnetite X-ray maps $\quad 38$

Trace element chemistry of Kiruna magnetite 39 
Trace element chemistry of the El Laco magnetite 40

Mineral deposit-type discrimination diagrams $\quad 42$

$\begin{array}{ll}\text { Magmatic vs. hydrothermal magnetite discrimination diagrams } & 47\end{array}$

Discussion $\quad 52$

The use of mineral deposit-type discrimination diagrams 53

The use of magmatic vs. hydrothermal magnetite discrimination diagrams $\quad 54$

Magnetite chemistry at Kiruna $\quad 55$

Magnetite chemistry at El Laco $\quad 57$

Chapter 3: Summary $\quad 66$ 


\section{List of Figures}

Fig. 1: Simplified geological maps of the study areas. 22

Fig. 2: LA-ICPMS BCR-2G average concentrations for this study. 30

Fig. 3: Mag BSE images and chemical X-ray maps; Kiirunavaara ore. 31

Fig. 4: Mag BSE images and chemical X-ray maps; smaller magnetite-apatite ores in Kiruna.

Fig. 5: Mag BSE images and chemical X-ray maps Laco Sur ore. 35

Fig. 6: Mag BSE images and chemical X-ray maps; El Laco andesite, Láscar volcano dacite.

Fig. 7: Trace element zoning in a Laco Sur ore Mag 41

Fig. 8: Loberg and Horndahl (1983) deposit-type Mag discrimination plots. 43

Fig. 9: Dupuis and Beaudoin (2011) deposit-type Mag discrimination plots. 45

Fig. 10. Knipping et al. (2015) Cr vs. V deposit-type Mag discrimination plot 46

Fig. 11. Nadoll et al. (2015) hydrothermal vs. magmatic (Ti vs V) Mag discrimination plots.

Fig. 12: Dare at al. (2014) hydrothermal vs. magmatic (Ti vs Ni/Cr) Mag discrimination plot

Fig. 13: Dare et al. (2014) hydrothermal vs. magmatic multi-element Mag discrimination plots. 


\section{List of Appendices}

\section{Appendix I-}

Sample list with GPS location, underground level (Kiruna samples) or Elevation (El Laco and Láscar samples), rock type, mineralogy and magnetite textures.

\section{Appendix II-}

Summarized methods for EPMA Fe analysis and LA-ICPMS trace element analyses of magnetite.

\section{Appendix III-}

Average (mean) LA-ICP-MS (ppm) and EPMA (Fe wt \%) results for trace elements used in plots from Kiruna and El Laco/Láscar magnetite samples. Minimum level of detection (LOD) calculated by Iolite reported for each analysis session.

\section{Appendix IV-}

EPMA Fe results. Spot locations are shown on BSE images of magnetite grains in Appendix VI.

\section{Appendix V-}

LA-ICPMS spot analysis results. Fe (wt. \%) is the mean concentrations of three or less EPMA analyses in the vicinity of LA-ICPMS spots. Spot locations are shown on BSE images of magnetite grains in Appendix VI.

\section{Appendix VI-}

LA-ICPMS and EPMA spot analysis locations on BSE images for Kiruna and El Laco magnetite.

\section{Appendix VII-}

LA-ICPMS spot analysis results for Mud Tank, Balmat and Bushveld magnetite. $\mathrm{Fe}(\mathrm{wt} \%)$ is the mean concentrations of three or less EPMA analyses in the vicinity of LA-ICPMS spots. Spot locations are shown on BSE images of magnetite grains in Appendix VI.

\section{Appendix VIII-}

LA-ICPMS spot analysis results (ppm) for BCR-2G glass during the Kiruna and E1 Laco analyses. 


\section{List of Abbreviations}

$\begin{array}{ll}\text { Mag } & \text { Magnetite } \\ f \mathrm{O}_{2} & \text { Oxygen fugacity } \\ f \mathrm{~S}_{2} & \text { Sulfur fugacity } \\ \mathrm{CVZ} & \text { Central Volcanic Zone } \\ \text { EPMA } & \text { Electron probe microanalyzer } \\ \text { LA-ICPMS } & \text { Laser ablation-inductively coupled plasma mass spectrometer } \\ \text { LOD } & \text { Level of detection } \\ \text { SEM } & \text { Scanning electron microscope } \\ \text { BSE } & \text { Back-scattered electron imaging } \\ \text { EDS } & \text { Energy dispersive spectroscopy }\end{array}$


Chapter 1: Introduction to the Research

\section{Introduction}

Genetic models for the formation of Kiruna-type magnetite-apatite deposits have been debated for over a century (e.g., Geijer, 1910; Geijer, 1919; Parák, 1975; Frietsch, 1978; Nyström and Henríquez, 1994; Bergman et al., 2001). The relationship between the host rock emplacement to their subsequent hydrothermal alteration and mineralization to form magnetite-apatite deposits remains controversial (Hitzman et al., 1992; Williams et al., 2005; Groves et al., 2010). Additional research is necessary in order to obtain a better understanding of the processes involved in forming magnetite-apatite deposits (Groves et al., 2010).

In a broad sense, there are two genetic models to describe how magnetite-apatite deposits formed in favor today, with a third model that involves a combination of the first two models: 1) Originating from immiscible iron-rich melts that separated from a silicate melt and were emplaced at subvolcanic levels or erupted and cooled at the surface (e.g., Henríquez and Martin, 1978; Nyström and Henríquez, 1994; Naslund et al., 2002; Nyström et al., 2008; Martinsson, 2016); 2) Metasomatic replacement of the host rocks by hydrothermal fluids (e.g., Hitzman et al., 1992; Rhodes and Oreskes, 1999; Sillitoe and Burrows, 2002; Edfelt et al., 2005; Groves et al., 2010; Valley et al., 2011; Dare et al., 2015; Westhues et al., in press); and 3) a magmatic-hydrothermal combination of these two models (e.g., Knipping et al., 2015; Tornos et al., 2016). A sedimentaryexhalative origin was suggested by Parák (1975) but was not widely accepted (Frietsch, 1978; Nyström et al., 2008). 
In this study, the trace element chemistry of magnetite was examined in situ from world-class magnetite-apatite localities of Kiruna in Sweden and El Laco of the Atacama Desert in Chile. The samples used in this study are from precisely known geographic locations and geologic environments. In Kiruna, magnetite grains were analyzed from the magnetite-apatite mineralization, footwall, hanging wall and spatially related felsic intrusive rocks. At El Laco, magnetite grains from the magnetite-apatite mineralization and host andesite rocks were analyzed. Magnetite from the volcanic rocks of the Láscar volcano nearby to El Laco, which does not have any known occurrences of magnetiteapatite mineralization, was also analyzed to compare with the andesite magnetite at El Laco. The magnetite trace element analyses results were evaluated using mineral deposittype and magmatic vs. hydrothermally derived magnetite discrimination diagrams.

\section{Research Statement}

The present study was undertaken to bring insight into the controversial origin of magnetite-apatite deposits through interpretation of the geochemical signatures of magnetite. For this type of study, magnetite (nominally $\left[\mathrm{Fe}^{2+} \mathrm{Fe}^{3+}{ }_{2}\right] \mathrm{O}_{4}$ ) was investigated because it has the following characteristics: 1) widespread occurrence in relevant deposit types and host rock assemblages; 2) can accommodate a broad range of minor and trace elements in its structure; and 3) is relatively resistant to weathering (i.e., mechanical and chemical surface processes), which potentially makes it an ideal provenance indicator for mineral exploration and useful for genetic studies of ore deposits (Lindsley, 1991; Grigsby, 1990; Dupuis and Beaudoin, 2011; Dare et al., 2014; Nadoll et al., 2014). 
Magnetite is a member of the spinel group of minerals, which have a cubic closepacking structure with tetrahedral (A) and octahedral (B) sites in coordination with oxygen anions. The magnetite crystal has the stoichiometry $\mathrm{AB}_{2} \mathrm{O}_{4}$, where $\mathrm{A}=\mathrm{Fe}^{2+}$ and $\mathrm{B}=\mathrm{Fe}^{3+}$ (Buddington and Lindsley, 1964; Lindsley, 1976). A variety of lithophile and siderophile elements with similar ionic radii to $\mathrm{Fe}^{2+}$ and $\mathrm{Fe}^{3+}$ substitute into magnetite, though in certain favorable physicochemical conditions chalcophile and other elements can also be incorporated (Nadoll et al., 2014).

Empirical discrimination plots have been proposed illustrating that magnetite from magnetite-apatite deposits contain distinct trace element chemical compositions compared to magnetite from other deposit types, such as banded iron formations (BIF), IOCG, porphyry $\mathrm{Cu}$ and Fe-Ti-V deposits (e.g., Loberg \& Horndahl, 1983; Dupuis and Beaudoin, 2011; Dare et al., 2014), as well as magnetite from unaltered volcanic rocks at El Laco (e.g., Dare et al., 2015). Dare et al. (2015) proposed that the distinct trace elements signatures of the magnetite from the magnetite-apatite ores at El Laco are explained by replacement of the andesite host rocks through precipitation of magnetite from Fe-rich fluids. The present study uses newly obtained data for magnetite trace element geochemistry to assess the general practical use and limitations of the proposed empirical magnetite discrimination diagrams; and whether they can be utilized in interpreting the mineralization style and ore genesis of magnetite-apatite deposits.

The magnetite trace element chemistry was determined through in situ spot analysis using a laser ablation inductively coupled mass spectrometer (LA-ICPMS). The LA-ICPMS data were reduced with Iolite software (Paton et al., 2011) using Fe (wt\%) 
concentrations that were determined by an electron probe micro-analyzer (EPMA) from the same areas of the grains.

\section{Research Questions}

Questions we address in this study include: 1) how useful are empirical magnetite discrimination diagrams in determining the type of mineral deposit of the magnetite?; 2) how useful are empirical magnetite discrimination diagrams in determining whether magnetite has formed magmatically or hydrothermally?; and 3) Can the trace element chemistry and textures of magnetite help shed light on the long-debated subject of how magnetite-apatite deposits form?

\section{Project Overview}

The findings from this research have been presented as a manuscript found in Chapter 2 of this thesis. The manuscript has been submitted to the journal Mineralium Deposita.

Appendix I contains the complete sample list with details regarding GPS coordinates, underground level (Kiirunavaara mine), Elevation (El Laco volcano), rock type, mineralogy and textures of the magnetite. The location of these samples are shown in Figure 1 of Chapter 2.

Appendix II contains summarized methods for EPMA and LA-ICPMS analysis of the magnetite.

Appendix III contains the average (mean) results for EPMA and LA-ICPMS analysis.

Appendix VI contains individual EPMA analysis for iron concentrations for each sample. EPMA spot locations can be found in Appendix VI. 
Appendix V contains LA-ICPMS data for each individual analysis. The Fe concentrations are presented here as the average of three or less EPMA analysis points in the vicinity of the corresponding LA-ICPMS spots; these values are also presented in Appendix IV. LA-ICPMS spot locations can be found in Appendix VI.

Appendix VI shows BSE images of the magnetite grains that were analyzed with the LA-ICPMS and EPMA spot locations for each sample.

Appendix VII contains LA-ICPMS and EPMA data for the Mudtank, Balmat, and Bushveld magnetite that were analyzed as secondary standards. Exact spot locations are not provided, as these magnetite grains were not analyzed in situ.

Appendix VIII contains LA-ICPMS spot analysis results for the primary standard reference material BCR-2G glass during the Kiruna and El Laco analysis runs and the Memorial University of Newfoundland long-term average for comparison. See Figure 2 in Chapter 2 for visual results of this data.

\section{Co-authorship Statement}

Each step of this thesis (i.e., the research proposal, practical aspects of the research, data analysis, and initial preparation of the manuscript) was primarily done by the author of this thesis, Shannon G. Broughm. The manuscript preparation, in Chapter 2, into its submitted form was a collaborative effort with the co-authors of the manuscript, however, the author of this thesis wrote the original draft of the manuscript.

\section{References}

Bergman S, Kubler L and Martinsson O (2001) Description of regional geological and geophysical maps of northern Norrbotten County (east of the Caledonian Orogen). Sveriges Geologiska Undersokning $56: 110$

Buddington AF and Lindsley DG (1964) Iron-titanium oxide minerals and synthetic equivalents. J Petrol $5(2): 310-357$ 
Dare SAS, Barnes S-J, Beaudoin G, Méric J, Boutroy E and Potvin-Doucet C (2014) Trace elements in magnetite as petrogenetic indicators. Miner Deposita 49:785-796

Dare SAS, Barnes S-J and Beaudoin G (2015) Did the massive magnetite "lava flows" of El Laco (Chile) form by magmatic or hydrothermal processes? New contraints from magnetite composition by LA-ICPMS. Miner Deposita 50:607-617

Dupuis C and Beaudoin G (2011) Discriminant diagrams for iron oxide trace element fingerprinting of mineral deposit types. Miner Deposita 46:319-335.

Edfelt A, Armstrong RN, Smith M and Martinsson O (2005) Alteration paragenesis and mineral chemistry of the Tjarrojakka apatite-rion and $\mathrm{Cu}(-\mathrm{Au})$ occurrences, Kiruna area, northern Sweden. Miner Deposita 40:409-434

Frietsch R (1978) On the magmatic origin of iron ores of the Kiruna type. Econ Geol 73:478-485

Geijer P (1910) Igneous rocks and iron ores of Kiirunavaara, Luossavaara and Tuollavaara. Scientific and practical researches in Lapland arranged by the Luossavaara-Kiirunavaara Aktiebolag - Geology of the Kiruna district, 2: Stockholm, p. 278

Geijer P (1919) Recent developments at Kiruna, SGU, C 288, p. 23

Grigsby JD (1990) Detrital magnetite as a provenance indicator. Journal of Sedimentary Petrology 60(6):940-951

Groves DI, Bierlein FP, Meinert LD and Hitzman MW (2010) Iron oxide copper-gold (IOCG) through earths history: implications for origin, lithospheric setting, and distinction from other epigenic iron oxide deposits. Econ Geol 105:641-654

Henríquez F and Martin RF (1978) Crystal growth textures in magnetite flows and feeder dykes, El Laco, Chile, Can Miner 16:581-589

Hitzman MW, Oreskes N and Einaudi MT (1992) Geological Characteristics and Tectonic Setting of Proterozoic Iron-Oxide (Cu-U-Au-Ree) Deposits. Precambrian Research 58:241-287

Knipping JL, Bilenker LD, Simon AC, Reich M, Barra F, Deditius AP, Wälle M, Heinrich CA, Holtz F and Munizaga R (2015) Trace elements in magnetite from massive iron oxide-apatite deposits indicate a combined formation by igneous and magmatic-hydrothermal processes. Geochim Cosmochim Acta 171:15-38

Lindsley DH (1976) The crystal chemistry and structure of oxide minerals as exemplified by the Fe-Ti oxides. In Oxide minerals. Mineralogical Society of America, Short Course Notes 3:L-1 to L-60

Lindsley DH (1991) Oxide minerals: petrologic and magnetic significance. Reviews in Mineralogy, Volume 25, Stony Brook, New York, USA

Martinsson O, Billström K, Broman C, Weihed P and Wanhainen C (2016) Metallogeny of the northern Norrbotten ore province, northern fennoscandian shield with emphasis on IOCG and apatite-iron ore deposits. Ore Geology Reviews. doi: 10.1016/j.oregeorev.2016.02.011

Nadoll P, Angerer T, Mauk JL, French D and Walshe J (2014) The chemistry of hydrothermal magnetite: a review. Ore Geology Reviews 61:1-32

Naslund HR, Henríquez FJ, Nyström JO, Vivallo W and Dobbs F (2002) Magmatic iron ores and associated mineralization: examples from the Chilean High Andes and Coastal Cordillera; in 
Porter, T.M. (Ed.), Hydrothermal Iron Oxide Copper-Gold \& Related Deposits: A Global Perspective, PGC Publishing, Adelaide, 2:207-226

Nyström JO and Henríquez F (1994) Magmatic features of iron ores of the Kiruna type in Chile and Sweden; ore textures and magnetite geochemistry. Econ Geol 89:820-839

Nyström JO, Billström K, Henríquez F, Fallick AE and Naslund H R (2008) Oxygen isotope composition of magnetite in iron ores of the Kiruna type in Chile and Sweden. Gff 130:177-188

Paton C, Hellstrom J, Paul B, Woodhead J and Hergt J (2011) Iolite: Freeware for the visualisation and processing of mass spectrometric data. Journal of Analytical Atomic Spectrometry 26:2508-2518. doi: $10.1039 / \mathrm{c} 1 \mathrm{ja} 10172 \mathrm{~b}$

Parák T (1975) Kiruna iron ores are not 'intrusive-magmatic ores of the Kiruna type'. Econ Geol 70:12421258

Rhodes AL and Oreskes N (1999) Oxygen isotope composition of magnetite deposits at El Laco, Chile: evidence of formation from isotopically heavy fluids. Soc of Econ Geol, Spec Pub 7:333-351

Sillitoe RH and Burrows DR (2002) New field evidence bearing on the origin of the el laco magnetite deposit, northern Chile. Econ Geol 97:1101-1109

Tornos F, Velasco F and Hanchar JM (2016) Iron oxide melts, magmatic magnetite and superheated magmatic-hydrothermal systems: the El Laco deposit, Chile. Geology 44:427-430; doi: $10.1130 / \mathrm{G} 37705.1$

Valley PM, Hanchar JM, Whitehouse MJ (2011) New insights on the evolution of the Lyon mountain granite and associated Kiruna-type magnetite-apatite deposits, Adirondack Mountains, New York State. Geosphere 7:357-389

Westhues A, Hanchar JM, Whitehouse MJ, Martinsson O (2016) New constraints on the timing of host rock emplacement, hydrothermal alteration and iron oxide apatite mineralization in and around Kiruna, Norrbotten region, northern Sweden. In press in Econ Geol

Williams PJ, Hedenquist JW, Barton MD, Johnson DA, Fontbote L, de Haller A, Mark G, Oliver NHS, Marschik R, Thompson JFH, Goldfarb RJ, Richards JP (2005) Iron oxide copper-gold deposits; geology, space-time distribution, and possible modes of origin. Econ Geol 100:371-405 


\section{Chapter 2:}

Mineral chemistry of magnetite from magnetite-apatite mineralization and their host rocks: Examples from Kiruna, Sweden and El Laco, Chile

Shannon G. Broughm ${ }^{1}$, John M. Hanchar ${ }^{1 *}$, Fernando Tornos ${ }^{2}$,

Anne Westhues ${ }^{1}$, Samuel Attersley ${ }^{1}$

${ }^{1}$ Department of Earth Sciences, Memorial University of Newfoundland

St. John's, NL A1B 3X5 Canada

${ }^{2}$ Centro de Astrobiología (CSIC-INTA), Ctra. Ajalvir, km 4.5

28850 Torrejón de Ardoz, Madrid, Spain

Revised manuscript submitted to Mineralium Deposita on December $27^{\text {th }}, 2016$ 


\begin{abstract}
Interpretation of the mineralizing environment of magnetite-apatite deposits remains controversial with theories that include a hydrothermal or magmatic origin, or a combination of those two processes. To address this controversy, we have analyzed the trace element content of magnetite from precisely known geographic locations and geologic environments from the Precambrian magnetite-apatite ore and host rocks in Kiruna, Sweden, and the Pliocene-Holocene El Laco volcano in the Atacama Desert of Chile. Magnetite samples from Kiruna have low trace element concentrations with little chemical variation between the ore, host, and related intrusive rocks. Magnetite from andesite at El Laco, and dacite from the nearby Láscar volcano, has high trace element concentrations typical of magmatic magnetite. El Laco ore magnetite have low trace element concentrations and displays growth zoning in incompatible elements ( $\mathrm{Si}, \mathrm{Ca}$, and Ce), compatible elements (Mg, Al, and Mn), LILE (Sr) and HFSE (Y, Nb, and Th). The El Laco ore magnetite are similar in composition to magnetite that has been previously interpreted to have crystallized from hydrothermal fluids; however, there is a significant difference in the internal zoning patterns. At El Laco each zoned element is either enriched or depleted in the same layers, suggesting the magnetite crystallized from a volatile-rich iron-oxide melt. In general, the composition of magnetite from these two deposits plot in very wide fields that are not restricted to the proposed fields in published discriminant diagrams. This suggests that the use of these diagrams and genetic models based on them should be used with caution.
\end{abstract}

Keywords Magnetite, magnetite-apatite deposits, Kiruna-type deposits, El Laco, magmatic-hydrothermal 


\section{Introduction}

Genetic models for the formation of Kiruna-type magnetite-apatite deposits have been discussed and debated for over a century (e.g., Geijer, 1910, 1919; Parák, 1975; Frietsch, 1978; Nyström and Henríquez, 1994; Bergman et al., 2001). How these deposits relate to their adjacent host rocks and the relationship of the ore mineralization with hydrothermal alteration remains controversial (Hitzman et al., 1992; Williams et al., 2005; Groves et al., 2010). Additional research is necessary in order to obtain a better understanding of the processes involved in forming these deposits and how they relate, if at all, to other types of ore deposits (e.g., Fe-Ti oxide, iron oxide copper gold [IOCG], porphyry copper, skarn, volcanogenic massive sulfide [VMS]) (Williams et al., 2005; Dupuis and Beaudoin, 2011; Nadoll et al., 2014). In the present study, the trace element chemistry of magnetite from perhaps the two most representative, and well known, magnetite-apatite deposits, and their respective host rocks, was determined. The first is from Kiruna in the Norrbotten region of northern Sweden, and the second is from El Laco in the Atacama Desert region of northern Chile. In the case of the Kiirunavaara deposit in Kiruna, magnetite from two related intrusive rocks were also analyzed. For El Laco, magnetite was also analyzed from the nearby Làscar volcano. The aim is to determine whether the trace element chemistry of magnetite can be used to aid in settling the dispute on the processes involved in magnetite-apatite mineralization, e.g., hydrothermal, or magmatic, or a combination of these two processes. All of the samples used in this study are from precisely known geographic locations and geologic environments allowing a spatial analysis of the magnetite textures and associated minerals together with their trace element compositions. 
Magnetite-apatite deposits can have high ore grades (up to $65 \% \mathrm{Fe}$ ) and large sizes (e.g., $\sim 2500$ million tons [Mt] of iron has been mined in Kiruna with $644 \mathrm{Mt}$ proven and probable reserves [Bergman et al., 2001; LKAB, 2015] and $~ 730 \mathrm{Mt}$ of iron ore at El Laco [Mario Rojo, Compañia Minera del Pacifico, 2015 pers. comm.]) making them attractive targets for mining. Magnetite-apatite deposits are the most important ore deposits in the Norrbotten region of northern Sweden (Bergman et al., 2001). The earliest studies on magnetite-apatite ores were focused on Kiruna (e.g., Geijer, 1910, 1935; Parák, 1975; Frietsch, 1978) where the expression "Kiruna-type" deposit was adopted for this class of low-Ti magnetite, apatite-rich iron ore (e.g., Hildebrand, 1986; Mücke and Younessi, 1994). Some later studies focused on the magnetite-apatite ores at El Laco in the Atacama Desert region of northern Chile, a much younger deposit, which is often considered a modern and shallow (i.e., Pliocene-Holocene) equivalent of the magnetiteapatite deposits found at Kiruna (e.g., Park, 1961; Nyström and Henríquez, 1994; Nyström et al., 2008).

Magnetite-apatite deposits are sometimes included as an end-member in the IOCG class of deposits (e.g., Hitzman et al., 1992; Barton and Johnson, 1996; Hitzman, 2000; Sillitoe, 2003). Both magnetite-apatite and IOCG deposits contain large volumes of distinctly low-Ti iron oxides within rocks that have undergone extensive alkali-calcic metasomatism by hydrothermal fluids. Magnetite-apatite deposits do not contain economic concentrations of $\mathrm{Cu}$ or $\mathrm{Au}$ and almost exclusively contain massive magnetite or both magnetite and hematite, while IOCG deposits may also contain iron-rich silicate phases (Parák, 1975; William et al., 2005; Groves et al., 2010). In some locations, magnetite-apatite deposits and IOCG deposits occur spatially, but usually not temporally, 
associated with each other; though, whether there is a genetic relationship between the formation of magnetite-apatite and IOCG deposits remains unresolved (e.g., Groves et al., 2010).

There are two genetic models, and a third that is a combination of the first two, for the formation of magnetite-apatite deposits today: 1) Crystallization from iron-rich melts that were immiscible from a parental silicate melt and were emplaced at different depths or erupted and crystallized at the surface (e.g., Henríquez and Martin, 1978; Nyström and Henríquez, 1994; Naslund et al., 2002; Alva-Valdivia et al., 2003; Nyström et al., 2008; Martinsson, 2016); crystallization was accompanied by the exsolution of large amounts of magmatic-hydrothermal fluids (Tornos et al., 2016); 2) Replacement of the host rocks by iron-rich hydrothermal fluids (e.g., Hitzman et al., 1992; Rhodes and Oreskes, 1999; Hitzman, 2000; Sillitoe and Burrows, 2002; Edfelt et al., 2005; Groves et al., 2010; Valley et al., 2011; Dare et al., 2015); and 3) a magmatic-hydrothermal genesis with an early generation of phenocrysts of magnetite that separated and floated from a crystallizing andesite melt and later were overgrown by hydrothermal magnetite (e.g., Knipping et al., 2015). A sedimentary-exhalative origin was suggested by Parák (1975) but was not widely accepted (Frietsch, 1978; Nyström et al., 2008) and will not be discussed further.

Field observations and geochemical data for magnetite-apatite deposits are arguably compatible with both magmatic and hydrothermal origins (Hitzman et al., 1992; Nyström and Henríquez, 1994; Naslund et al., 2002). Field evidence at the El Laco ore bodies that strongly supports an ultimate magmatic origin for the mineralization, i.e., direct crystallization from an iron-rich melt, includes distinct magnetite volcanic flow 
structures, vesicles in the magnetite ore veins with chilled margins that crosscut the host andesite, as well as the presence of degassing tubes similar to textures observed in basaltic flows (Henríquez and Martin, 1978; Nyström and Henríquez, 1994; Naslund et al., 2002; Henríquez 2003; Tornos et al., 2016).

Arguments that support a hydrothermal (metasomatic) origin at El Laco include the presence of, sometimes jigsaw-like, breccias in which the magnetite supports fragments of altered host andesite blocks; a feature that is explained by open-space filling of ascending hydrothermal fluids (Sillitoe and Burrows, 2002). Brecciated contacts between the ore and hydrothermally altered host rocks are fairly common at other magnetite-apatite deposits (e.g., Kiruna, the Adirondacks/New York State, and Bafq/Iran; Geijer, 1910; Bergman et al., 2001; Valley et al., 2011; Sabet-Mobarhan-Talab et al., 2015; Westhues et al., 2016). Metasomatism of the host rocks surrounding these deposits is strong evidence that hydrothermal fluids were present. In Kiruna the host rocks are pervasively hydrothermally altered (Westhues et al., 2016); however, at El Laco there is not always direct contact between the altered host rock and ore suggesting the hydrothermal alteration here may not be directly related to ore emplacement (Tornos et al., 2016).

The magmatic model for magnetite-apatite ores involves the existence of immiscible iron rich-melts that crystallized to produce the large volumes of massive magnetite. This type of melt is considered to be similar to nelsonite deposits, which have a 2:1 oxide:apatite ratio and contain abundant $\mathrm{Ti}$ in the form of mostly rutile $+/$ - ilmenite +/- titanomagnetite). (Philpotts, 1967; Frietsch, 1978; Kolker, 1982; Dymek and Owens, 2001). Kamenetsky et al. (2013) tracked the existence of a large immiscibility gap 
between silica-rich felsic melts and silica-poor mafic melts. The mechanism(s) through which the iron-rich melts efficiently segregate into the ore and a presumed residual parent silicate-rich melt at the scale of massive deposits like those in Kiruna or El Laco, has not yet been determined or observed in the field (i.e. the magnetite-apatite ore and residual silicate-melt in contact with each other). However, immiscible iron-rich and silicate melts have been observed within melt inclusions in the host andesite rocks at El Laco (Tornos et al., 2016; Velasco et al., 2016).

Hydrothermal models for magnetite-apatite deposits are extrapolated from hydrothermal models for IOCG deposits, with the assumption that these two types of deposits are genetically similar (Barton and Johnson, 2004). Two main fluid sources have been proposed: 1) hydrothermal fluids exsolved from a magmatic source (e.g., Sillitoe and Burrows, 2002; Groves et al., 2010); or, 2) derived from an external source (e.g., basinal brines) where igneous intrusions are a heat source for circulating fluids in the crust (e.g., Barton and Johnson, 1996; Rhodes and Oreskes, 1999). Each system would require the generation of saline, sulfur-poor, and oxidized fluids (Barton and Johnson, 2004). It is possible that there are multiple sources for the fluids and they may vary between different localities (Williams et al., 2005; Valley et al., 2011).

Magnetite is an abundant and widespread oxide mineral and occurs in igneous, sedimentary, hydrothermal, and metamorphic rock assemblages and different types of ore deposits (Lindsley, 1991). Magnetite is a member of the spinel group of minerals, which have a cubic close-packing structure with tetrahedral $\left(\mathrm{Fe}^{2+}\right)$ and octahedral $\left(\mathrm{Fe}^{3+}\right)$ sites in coordination with oxygen anions and the general stoichiometry $\mathrm{Fe}^{2+} \mathrm{Fe}^{3+}{ }_{2} \mathrm{O}_{4}$ (Buddington and Lindsley, 1964; Lindsley, 1976). A variety of lithophile and siderophile elements 
with similar ionic radii to $\mathrm{Fe}^{2+}$ and $\mathrm{Fe}^{3+}$ substitute in the magnetite structure (e.g., $\mathrm{Mg}, \mathrm{Al}$, $\mathrm{Si}, \mathrm{P}, \mathrm{Ca}, \mathrm{Ti}, \mathrm{V}, \mathrm{Cr}, \mathrm{Mn}, \mathrm{Co}, \mathrm{Ni})$, though in certain favorable physicochemical conditions chalcophile and other elements can also be incorporated (e.g., $\mathrm{Cu}, \mathrm{Zn}, \mathrm{Ga}, \mathrm{Sn}, \mathrm{Ce}$ ) (Nadoll et al., 2014). Of special interest is the behavior of Ti; the solubility of Ti in magnetite is controlled by the redox state and temperature of the system (Lindsley, 1976). Magnetite is known to be resistant to surface weathering making it an ideal provenance indicator for mineral exploration and perhaps useful for genetic studies of ore deposits (Grigsby, 1990; Dupuis and Beaudoin, 2011; Dare et al., 2012; Nadoll et al., 2014). Several previous studies have discussed magnetite trace-element chemistry from Kiruna, El Laco, and other magnetite-apatite deposits (e.g., Loberg and Horndahl 1983; Frietsch 1995; Muller et al., 2003; Dupuis and Beaudoin 2011; Dare et al., 2015); however, most of the magnetite samples used in these studies were not from precisely known locations within the ore and surrounding host rocks. Some of these studies have proposed empirical plots in which the magnetite of different types of mineralization have a characteristic trace element signature. In these diagrams, magnetite from magnetiteapatite deposits have distinct trace element chemical compositions compared to magnetite from other deposit types, such as banded iron formations (BIF), IOCG, nelsonite, porphyry $\mathrm{Cu}$ and Fe-Ti-V deposits (e.g., Loberg and Horndahl, 1983; Dupuis and Beaudoin, 2011; Dare et al., 2014). Dare et al. (2015) proposed that the composition of the magnetite from the El Laco ore, which is different to that of the accessory magnetite in the unaltered host andesite, is consistent with a hydrothermal origin for the magnetiteapatite ore (e.g., Dare et al., 2015). 
The present study uses newly obtained data on the magnetite trace element geochemistry to assess the practical use and limitations of the proposed empirical magnetite discrimination diagrams and whether they can be utilized in interpreting the mineralization style and ore genesis of magnetite-apatite deposits.

\section{Geologic background}

\section{Kiruna geology and magnetite-apatite ores}

There are over 40 known magnetite-apatite deposits located in the Norrbotten region, with Kiirunavaara being the largest estimated at nearly 2 Ga before extraction of high-grade iron ore averaging 30-70\% Fe (e.g., Cliff et al., 1990; Hallberg et al., 2012; Martinsson, 2016; Westhues et al., 2016). The Kiirunavaara magnetite-apatite deposit is a tabular-shaped ore body approximately $5 \mathrm{~km}$ long, $100 \mathrm{~m}$ thick and at least $1500 \mathrm{~m}$ deep that lies concordant within steeply dipping volcanic host rocks (e.g., Parák, 1975; Blake, 1992; Bergman et al., 2001; Harlov et al., 2002; Nyström et al., 2008).

The oldest unit in the Kiruna area are the Karelian (2.4-1.96 Ga) maficintermediate metavolcanic flows (Kiruna Greenstone Group), overlain by metasedimentary and intermediate-felsic metavolcanic rocks of the Svecofennian Porphyry group (1.96-1.75 Ga) (Fig. 1a) (e.g., Bergman et al., 2001). The magnetiteapatite deposits in the Kiruna area are hosted by the metavolcanic rocks of the Porphyry Group (Parák, 1975; Martinsson, 2004). The Kiirunavaara-Luossavaara ore bodies follow the contact between thick trachyandesitic lava flows (footwall) and pyroclastic rhyodacites (hanging wall). The entire Norrbotten region has been subjected to greenschist facies metamorphism (Bergman et al., 2001) and is overprinted by regional 


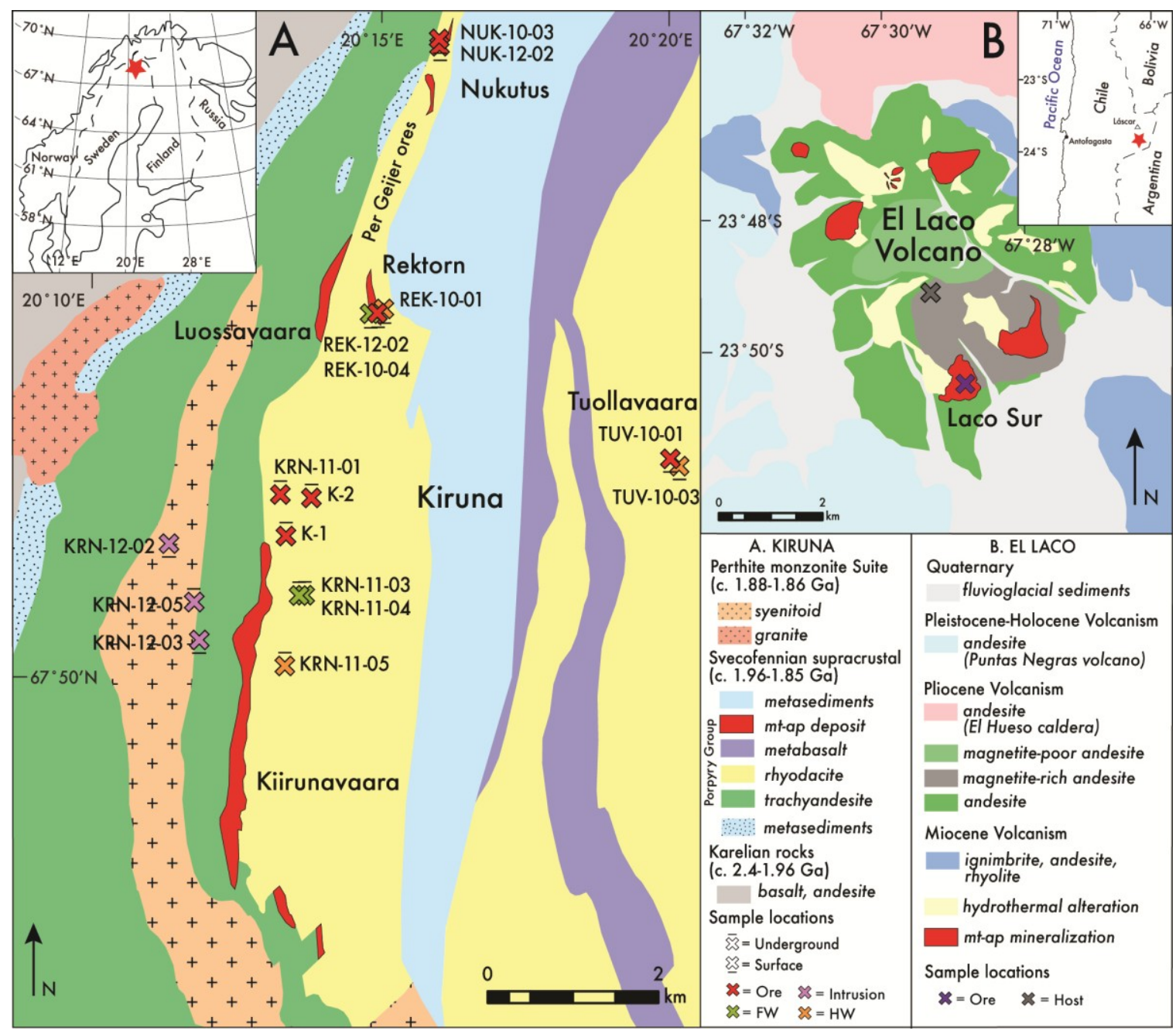

Fig. 1. Simplified geological maps of the study areas. a) Kiruna district, Norrbotten region, northern Sweden, with sample locations for this study. The Kiirunavaara magnetite-apatite deposit dips eastward between the footwall and hanging wall rock units. Samples collected underground within the mine are projected to the map surface and therefore appear to the east of ore body (map modified after SGU data and Westhues et al., 2016). b) El Laco volcano, ore samples from this study are from the Laco Sur deposit with one dacite sample from the Láscar volcano shown in the inset map (map modified after Tornos et al., 2016)

scale $\mathrm{Na}$ and $\mathrm{Cl}$ metasomatism in the form of albite and Cl-rich scapolite $\left(\mathrm{Na}_{4} \mathrm{Al}_{3} \mathrm{Si}_{9} \mathrm{O}_{24} \mathrm{Cl}-\mathrm{Ca}_{4} \mathrm{Al}_{6} \mathrm{Si}_{6} \mathrm{O}_{24} \mathrm{CO}_{3}\right)$ (Frietsch et al., 1997).

There is a syenite intrusion approximately $1 \mathrm{~km}$ stratigraphically below the Kiirunavaara ore body (Blake, 1992; Bergman et al., 2001). Granophyric to granitic 
dykes intrude the Kiirunavaara ore, and a larger body of potassic granite can be found within the footwall of the Kiirunavaara mine. New constraints on the ages of these intrusions show that the syenite (1880 \pm 7 and $1881 \pm 4 \mathrm{Ma})$ is of a similar age to the metavolcanic host rocks (1884 \pm 4 and $1880 \pm 3 \mathrm{Ma})$ and older than the ore $(1877 \pm 4$ and $1874 \pm 7 \mathrm{Ma})$, while zircon from the granite $(1874 \pm 7 \mathrm{Ma})$ and two ore samples have overlapping ages (Westhues et al., 2016).

Two types of ore can be identified at Kiirunavaara based on their phosphorous content, primarily residing in apatite: the B-ore $(<0.05 \% \mathrm{P})$ and D-ore $(>1 \% \mathrm{P})$ (e.g., Bergman et al., 2001). The ore is rich in rare earth elements (REE); dominantly as light rare earth elements contained within the apatite or in inclusions of monazite in apatite, which is currently not mined (Hallberg et al., 2012). The contact with the host rocks is bounded by a magnetite-actinolite filled breccia with veins that can be found extending tens of meters into the hanging wall (Bergman et al., 2001). The footwall at Kiirunavaara is strongly albitized, especially near the syenite intrusion, and here widespread amygdales are found to contain secondary magnetite, actinolite and titanite (Geijer, 1910; Romer et al., 1994; Bergman et al., 2001).

The Tuollavaara and Per Geijer (e.g., Nukutusvaara and Rektorn) ore bodies are smaller than Kiirunavaara and are hosted within rhyodacites in the upper parts of the Porphyry Group (Martinsson, 1994; Bergman et al., 2001). Hematite is more common in these smaller deposits than at Kiirunavaara. Contacts between the ore and host rocks are often brecciated (i.e., altered host rock fragments are surrounded by veins of iron oxides + apatite) and veining of iron ore commonly extends into both footwall and hanging wall up to tens of meters (Bergman et al., 2001). 


\section{El Laco geology and magnetite-apatite ores}

The El Laco andesite stratovolcano is located in the current active volcanic arc, the Central Volcanic Zone (CVZ), of the Andes in the Atacama Desert of northern Chile (Fig. 1b). The volcano is made up of calc-alkaline andesite flows and pyroclastic rocks, with K-Ar dates from 5.3 +/- 1.9 Ma to 1.6 +/- 0.5 Ma (Naranjo et al., 2010). There are seven high-grade iron ore bodies at El Laco that reach up to $1 \mathrm{~km}^{2}$ at the surface and exceeding $100 \mathrm{~m}$ thickness. (Naslund et al., 2002). The dominant magnetite mineralization occurs as large stratabound lenses that are texturally massive, brecciated, vesicular or friable and are interpreted as lava flows or pyroclastic rocks. They are rooted in subvertical veins of massive and coarse grained magnetite (Henríquez and Martin, 1978; Nyström and Henríquez, 1994; Naslund et al., 2002; Nyström et al., 2016; Tornos et al., 2016). The magnetite ore is associated with minor amounts of diopside, scapolite and anhydrite (Tornos et al., 2016) while apatite is fairly uncommon in the stratabound ores but is abundant in the feeder dykes.

The magnetite-apatite ore bodies and some of the andesite host rocks have been pervasively overprinted by hydrothermal alteration that is thought to be broadly synchronous with the emplacement of the magnetite ore (see Fig. 1b). The andesite has been locally replaced by alkali-calcic hydrothermal assemblages, including diopside, Kfeldspar, magnetite, anhydrite and scapolite that are related to widespread brecciation of the altered andesite (Tornos et al., 2016). The andesite host and the alkali-calcic altered rocks are overprinted by a later and shallower steam-heated alteration that is observed as stratabound zones of dominantly alunite and gypsum (Sillitoe and Burrows, 2002; Tornos et al., 2016). Late martitization related to the steam-heated alteration overprints large parts of the magnetite ore (Tornos et al., 2016). 


\section{Láscar volcano}

The Láscar volcano is located approximately $57 \mathrm{~km}$ northwest of E1 Laco $\left(67^{\circ} 43^{\prime} \mathrm{W} ; 23^{\circ} 22^{\prime} \mathrm{S}\right)$ and is the most active volcano in the CVZ today with a significant eruption in 1993 and intermittent activity ever since (Tassi et al., 2009). Láscar is considered a typical arc-related volcano with andesitic to dacitic composition. The andesite-dacite at Láscar includes anhydrite phenocrysts as well as droplets of magnetite no significant concentrations of massive magnetite have been described. The reason to compare the geochemistry of magnetite at El Laco and Láscar volcanoes is to determine if a difference exists with the magnetite from a volcano with massive magnetite mineralization, such as El Laco, with a similar volcano located within the same volcanic arc system that does not have visible massive magnetite deposits, such as Láscar.

\section{Analytical methods}

\section{Sample selection and preparation}

The magnetite-bearing rocks of this study have been selected using a systematic sample collection that was carried out from magnetite-apatite ores and their respective host rocks in the Norrbotten region of northern Sweden and the El Laco and Láscar volcanoes (Fig. 1 and Appendix I). The samples have been thoroughly examined using cross-polarized and reflected light microscopy on polished thin sections in order to select the samples with minimal replacement of magnetite by hematite. Magnetite grains were chosen in situ from the samples of ore, hanging wall, and footwall as well as from any spatially associated intrusive rocks. Some samples from the host rocks did not contain magnetite or the grains were not large enough for laser ablation analysis and therefore 
could not be included in this study (e.g., many of the more felsic hanging wall rocks at Kiruna and altered andesite at El Laco).

For Kiruna, samples that contain sufficient magnetite included all the ore samples from the Kiirunavaara high-P (KRN-10-02, K-1 and KRN-11-01) and low-P (K-2) ore and the selected smaller magnetite-apatite ores, Tuolluvaara (TUV-10-01), Nukutusvaara (NUK-12-02 and NUK-10-03) and Rektorn (REK-10-04). The Rektorn ore also contains abundant hematite, described further below. At Kiirunavaara, the footwall andesite rocks were magnetite-rich and there was an altered (KRN-11-04) and a less altered (KRN-1103) sample chosen. One sample from the hanging wall rhyodacite rocks at Kiirunavaara contained a small amount of magnetite (KRN-11-05). Several samples containing magnetite from felsic intrusive bodies spatially associated with the Kiirunavaara ore body were also chosen, these included an aplite vein (KRN-12-02) a syenite pluton (KRN-1203 ) and a granite pluton from underground inside the mine (KRN-12-05). As mentioned above, the smaller magnetite-apatite bodies in Kiruna (i.e., Per Geijer ores: Rektorn, Nukutus, and Tullovaara) are hosted in the rhyodacitic rocks that generally do not contain abundant magnetite. However, sufficiently sized magnetite was present in the host rock at Tuollavaara (TUV-10-03). The Rektorn footwall (REK-12-02) contains abundant magnetite and the Rektorn hanging wall was eliminated from this study because it contains abundant hematite.

At El Laco in the upper levels of the large magnetite-apatite ore body at Laco Sur two massive magnetite ore samples were collected (ELL-14-04 and ELL-14-05). In the lower levels of the Laco Sur ore body (at approximately 4650 m elevation) a magnetite vein from a feeder structure was sampled (ELL-14-06). A sample of andesite from the El 
Laco volcano (ELL-14-02) and a dacite sample from Láscar (LAS-14-07) were also collected.

The magnetite-bearing samples selected ( $\mathrm{n}=17$ from Kiruna; $\mathrm{n}=4$ from El Laco and $n=1$ from Láscar) were first trimmed with a saw to remove any altered or weathered material and then mounted in $25 \mathrm{~mm}$ diameter by $6 \mathrm{~mm}$ tall epoxy pucks. These pucks were then polished and carbon coated and examined with a JEOL 7100F scanning electron microscope (SEM) at Memorial University of Newfoundland equipped with energy dispersive spectroscopy (EDS) at $15 \mathrm{kV}$ and $50 \mathrm{nA}$. Magnetite grains, as well as any associated minerals, were identified using back-scattered electron (BSE) imaging and confirmed with EDS and later with conventional reflected light microscopy to distinguish between magnetite and hematite.

\section{EPMA analyses}

The iron content of the magnetite grains was measured using a JEOL JXA-8230 SuperProbe electron probe microanalyzer (EPMA) at Memorial University of Newfoundland. Details concerning the EPMA analyses are summarized in Appendix II and a complete list of the Fe results in Appendix IV. Quantitative chemical analyses of magnetite were done to obtain Fe concentrations in the same location as the LA-ICPMS analyses to use $\mathrm{Fe}$ as the internal standard for reducing the laser ablation data with Iolite software (Paton et al., 2011). The following conditions were used for the EPMA analyses: accelerating voltage of $15 \mathrm{kV}$, sample current of $100 \mathrm{nA}$, peak and background count times of $10 \mathrm{~s}$ and a beam diameter of $3 \mu \mathrm{m}$. Natural magnetite from the Astimex MINM25-53 mineral standards mount was used as a primary Fe standard. Raw X-ray intensities were corrected using standard ZAF techniques with the JEOL software. 


\section{X-ray maps}

X-ray maps of the Kiruna magnetite grains were made on one representative magnetite grain per sample for $\mathrm{Al}, \mathrm{Si}, \mathrm{Ca}$, Ti and V. Vanadium was mapped instead of $\mathrm{Mg}$ for the Kiruna analyses after variations in $\mathrm{V}$ were detected with energy dispersive spectroscopy (EDS). Aluminum and Ti were also chosen because of their generally immobile nature in hydrothermal fluids. Silica and Ca were chosen for their highly mobile nature in hydrothermal fluids (Dare et al., 2014; Nadoll et al., 2014). For the El Laco samples, EPMA X-ray maps for $\mathrm{Al}, \mathrm{Si}, \mathrm{Ca}, \mathrm{V}$, and $\mathrm{Mg}$ were acquired on one representative magnetite grain per sample. For each map an accelerating voltage of 15 $\mathrm{kV}$, and sample current of $250 \mathrm{nA}$, and a pixel dwell time of $150 \mathrm{~ms}$ was used. The map area, step size and total time to create each map ranged from $150 \mu \mathrm{m}^{2}$ to $2 \mathrm{~mm}^{2}, 0.4$ to $1.0 \mu \mathrm{m}$, and 4 to 10 hours, respectively, depending on the size of the magnetite grain.

\section{LA-ICPMS analyses}

In situ LA-ICPMS analyses were done at the MicroAnalysis Facility - Bruneau Innovation Centre (MAF-IIC) at Memorial University of Newfoundland using a Finnigan Element XR high-resolution double-focusing magnetic-sector inductively coupled plasma mass spectrometer (HR-ICPMS), coupled to a GeoLas 193 nm Excimer laser system. Details for the LA-ICPMS analyses are summarized in the Appendix II. Zipkin et al. (2015) describes the current methodology in the LA-ICPMS facility for trace element analysis using this equipment; these same methods were used in the present study with the modifications noted below.

A laser spot diameter of $30 \mu \mathrm{m}$ was used for all magnetite analyses, a $59 \mu \mathrm{m}$ spot was used for the primary calibration material NIST 610 , and a $49 \mu \mathrm{m}$ spot for the 
secondary standard reference material BCR-2G. A total of 42 elements and 35 elements, respectively, were analyzed for each magnetite analysis during the Kiruna and El Laco LA-ICPMS analyses. Magnetite samples from E1 Laco were analyzed prior to the Kiruna samples and elements that were consistently below the limit of detection (LOD) were not measured during the Kiruna analyses after verifying that those elements were again not detectable. Instead, rare earth elements (REE) were included for the Kiruna analyses in order to make a comparison with the well-constrained trace REE concentrations in the BCR-2G glass (Jochum et al., 2005). The laser energy density used for all laser ablation analyses was $3 \mathrm{~J} / \mathrm{cm}^{2}$ with a pulse frequency of $8 \mathrm{~Hz}$. For each analysis, the background was measured for about $30 \mathrm{~s}$, followed by $90 \mathrm{~s}$ of laser ablation, and wash out was monitored for about $20 \mathrm{~s}$ after each ablation. Isotope signals ${ }^{57} \mathrm{Fe},{ }^{51} \mathrm{~V}$, and ${ }^{9} \mathrm{Co}$ were closely monitored during the day to track instrumental drift. For the El Laco ablation session laser spots were taken across grains that showed zoning in BSE and X-ray maps. A total of 72 analyses were done on magnetite from El Laco and Láscar. Eighty-seven analyses were done on magnetite from the Kiruna area samples. A complete list of the analyses that was done as well as the spot locations is reported in the Appendix V and VI, respectively.

The LA-ICPMS data were reduced using the Iolite software (Paton et al., 2011) with the Fe concentration from the EPMA analysis used as the internal standard. Peaks for $\mathrm{La}, \mathrm{Ce}, \mathrm{Al}, \mathrm{Mg}, \mathrm{Zr}, \mathrm{Si}, \mathrm{P}, \mathrm{Ca}$, and $\mathrm{Ti}$ were monitored during the data reduction to avoid inclusions of other minerals (e.g., monazite, apatite, zircon, titanite) or inclusion of the host material in the case of tiny magnetite grains (e.g., feldspar, amphibole, quartz). The LOD for each of the elements measured was calculated in Iolite (Paton et al., 2011) 
using the method described in Zipkin et al. (2015). The LOD and mean results of each isotope measured are listed in Appendix III. The BCR-2G results from the Kiruna and El Laco analysis sessions show excellent correlation with the long term running averages for BCR-2G collected over a span of 17 years at Memorial University (see Fig. 2 and Appendix VIII).

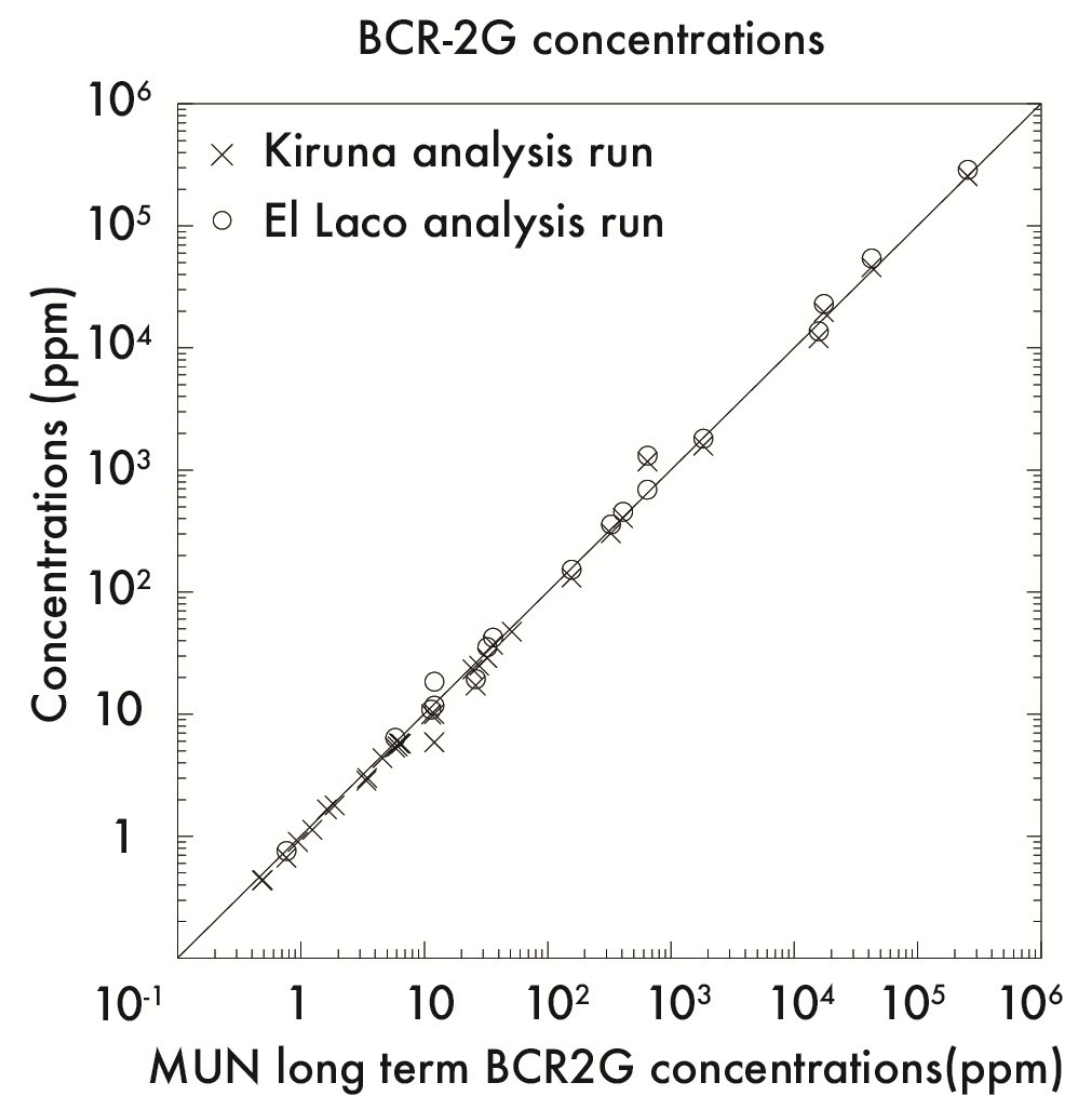

Fig. 2. LA-ICP-MS BCR-2G average concentrations for this study (y-axis) compared with the MUN BCR-2G long term average from 1997-2014 (x-axis).

\section{Results}

Kiruna magnetite textures and associated minerals

From the samples investigated at Kiirunavaara, the D-ore (i.e., high-P ore) contains two types of magnetite: 1) massive magnetite with interstitial apatite, biotite, and 


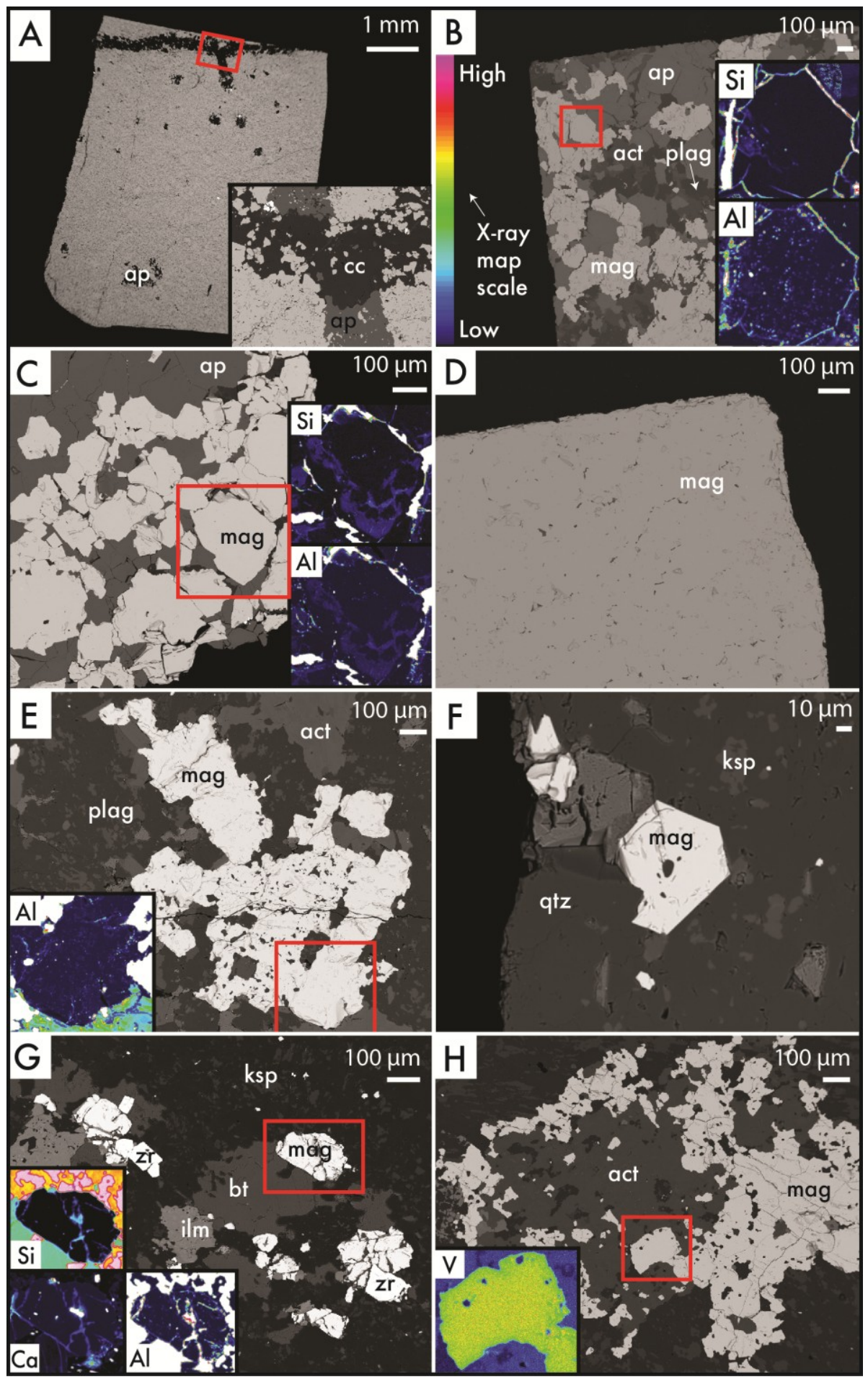

Fig. 3. Back-scattered electron images and chemical X-ray maps of representative magnetite ( $\mathrm{mag}$ ) from the Kiirunavaara ore, host rocks and associated intrusive rocks. Relative chemical variation scale for X-ray maps in b. Red boxes show locations of BSE images or X-ray maps that are shown as insets. a) KRN-10-02 (D-ore), massive magnetite with interstitial apatite $(a p)$ and cross cutting calcium carbonate $(c c)$ vein. $\mathrm{b}$ ) 
K-1 (D-ore), subhedral magnetite grains with zones of slight increases in Si and Al shown in X-ray map. c) KRN-11-01 (D-ore), subhedral magnetite with correlating zones of increased in Si and Al. d) K-2 (B-ore), massive magnetite. e) KRN-11-04 (FW), anhedral magnetite aggregate associated with actinolite (act), X-ray map shows spots of increased Al. f) KRN-11-05 (HW), small euhedral-subhedral magnetite grain. g) KRN12-02 (syenite intrusive), small anhedral magnetite grains associated with zircon $(z r)$, biotite $(b t)$ and ilmenite $(\mathrm{ilm})$, cracks filled with increased $\mathrm{Ca}, \mathrm{Si}$ and $\mathrm{Al}$ concentrations. h) Anhedral magnetite associated with actinolite, rim of magnetite depleted in V relative to the core. Other mineral abbreviations: K-feldspar $(k s p)$, quartz $(q t z)$ and plagioclase (plag).

later calcite (Fig. 3a); and 2) 20-200 $\mu \mathrm{m}$ magnetite grains that are subhedral to anhedral with apatite as the dominant gangue mineral phase $+/$ - actinolite, plagioclase, and quartz (Fig. 3b, c). The B-ore (i.e., low-P ore, Fig. 3d) magnetite is massive with interstitial biotite and calcite and contains much less apatite (and thus phosphorus) than the D-ore. The Kiirunavaara trachyandesitic footwall has large anhedral magnetite grains ranging in size from 100-300 $\mu \mathrm{m}$ that are found in clusters as well as disseminated magnetite. The magnetite clusters are more abundant and larger (approximately $1 \mathrm{~mm}$ in diameter) in the altered footwall (Fig. 3e) compared to the less altered footwall (approximately $500 \mu \mathrm{m}$ in diameter). The hanging wall rocks at Kiirunavaara have a low abundance of magnetite with grains that are euhedral-subhedral and $<60 \mu \mathrm{m}$ (Fig. 3f). The aplite vein sample (KRN-12-02) has a low abundance of magnetite with grains that are $<100 \mu \mathrm{m}$, fractured and associated with biotite, titanite and zircon (Fig. 3g). The syenite sample (KRN-1203) has 50-100 $\mu \mathrm{m}$ sized anhedral magnetite grains that are commonly associated with actinolite (Fig. 3h). The potassic granite intrusion (sample KRN-12-05) found underground within the mine (Westhues et al., 2016) has disseminated euhedral to anhedral magnetite grains that are $<60 \mu \mathrm{m}$ in size. 
The Tuollavaara ore has subhedral to anhedral magnetite grains that range in size from 100-800 $\mu \mathrm{m}$ (Fig. 4a). The host rock at Tuollavaara has disseminated magnetite with typically $1 \mathrm{~mm}$ sized clusters of $<100 \mu \mathrm{m}$ sized grains that are anhedral (Fig. 4b).

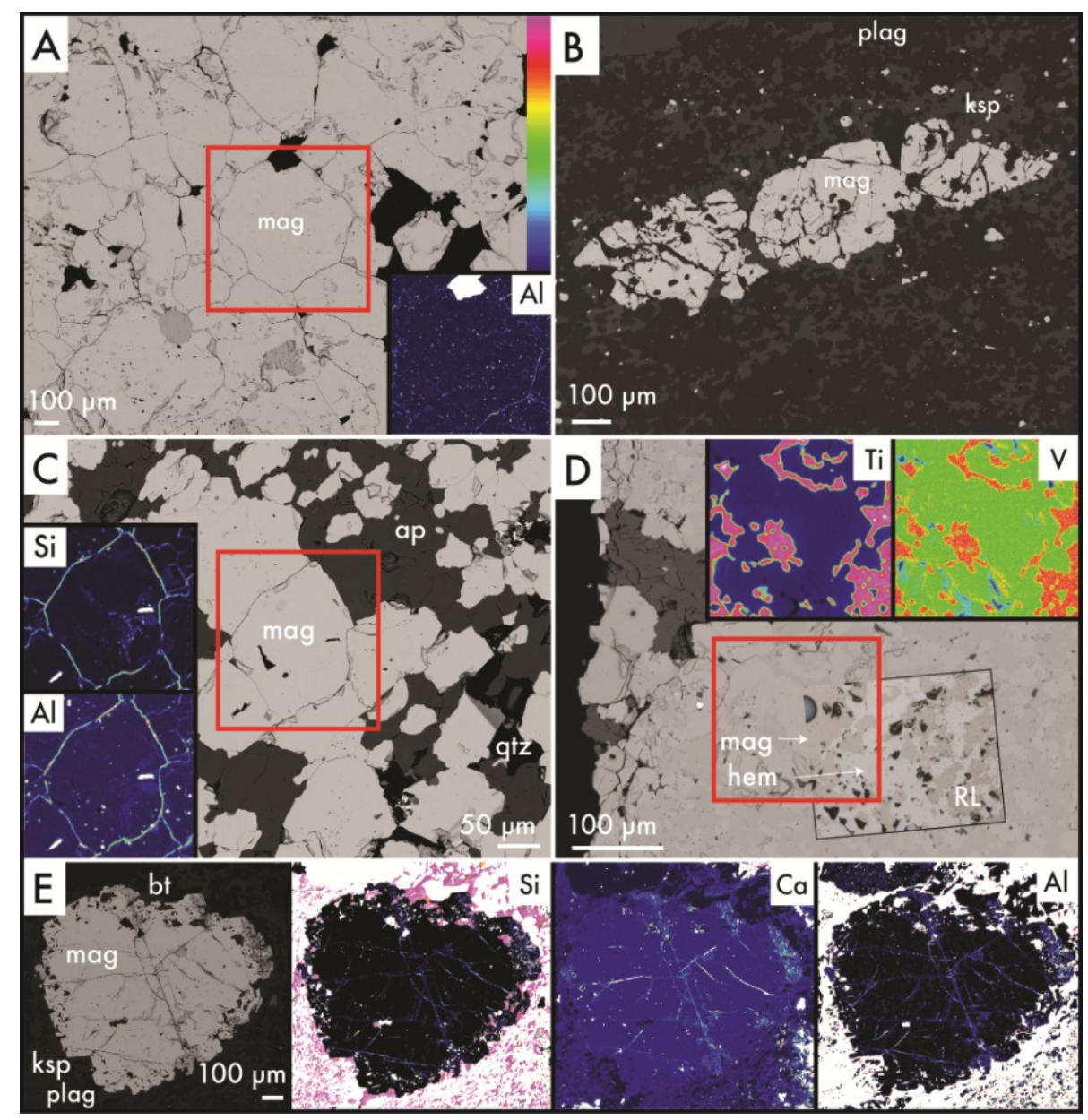

Fig. 4. Back-scattered electron images and chemical X-ray maps of representative magnetite ( $\mathrm{mag}$ ) from the smaller magnetite-apatite ores and their host rocks in Kiruna. Relative chemical variation scale for X-ray maps in a. Red box surrounds area of X-ray maps that are shown as insets. a) TUV-10-01 (ore) equally distributed spots of high aluminum present in X-ray map are visible as darker spots in the BSE image b) TUV-1003 (hanging wall), anhedral magnetite. c) NUK-10-03 (ore), X-ray maps of Si and A1 show a correlation. d) REK-10-04 (ore), massive magnetite with dark hematite (hem) and brighter magnetite areas in BSE correlating to white and pink, respectively, in reflected light (RL). The hematite has high Ti and V compared to the magnetite in the X-ray maps. e) REK-12-02 (FW), correlating increase in $\mathrm{Ca}, \mathrm{Si}$ and $\mathrm{Al}$ are located along fractures in magnetite grain as seen in BSE image (left). 
The Nukutus ore has subhedral to anhedral magnetite grains that range in size from 10$150 \mu \mathrm{m}$ with abundant apatite and interstitial actinolite $+/$ - quartz, calcite and biotite (Fig. 4c). The Rektorn ore is massive with interstitial calcite and quartz; BSE imaging revealed that approximately $60 \%$ of ore is lighter and therefore different in composition; under reflected light it was determined that the lighter BSE iron oxide is magnetite and the darker BSE iron oxide is hematite (Fig. 4d); both iron oxide phases were analyzed and differences in the chemistry are described in more detail below. The Rektorn footwall host rocks contain abundant $1 \mathrm{~mm}$ sized magnetite grains with rims that are rich in inclusions of feldspar, biotite and quartz (Fig. 4e).

\section{El Laco magnetite textures and associated minerals}

The magnetite ore samples studied at the Laco Sur magnetite-apatite deposit are dominated by massive or anhedral magnetite, up to $2 \mathrm{~mm}$ sized euhedral to subhedral grains can be found along the edges of void spaces (Fig. 4). Unlike the magnetite-apatite ore at Kiruna the El Laco magnetite is generally not associated with other mineral phases and shows partial to extensive alteration to martite (i.e., pseudomorphic replacement of magnetite by hematite). One of the samples from the upper levels of the ore body (ELL14-04) consists primarily of massive magnetite or anhedral $\mu \mathrm{m}$-sized grains of magnetite; there are abundant $\mathrm{cm}$-sized elongated voids that are lined by $200-400 \mu \mathrm{m}$ euhedral magnetite crystals.

In BSE images, the magnetite grains have porous inner cores that display chemical growth zoning and outer regions with no detectable chemical zoning (Fig. 4a). Under reflected light the magnetite crystals show extensive alteration to kenomagnetite

(nominally $\mathrm{Fe}^{2+}{ }_{1-\mathrm{y}}\left(\mathrm{Fe}^{3+}{ }_{1-2 / 3 \mathrm{y}}[]_{\mathrm{y} / 3} \mathrm{O}_{4}\right)$ and less extensively hematite along fractures (Fig. 4a) 


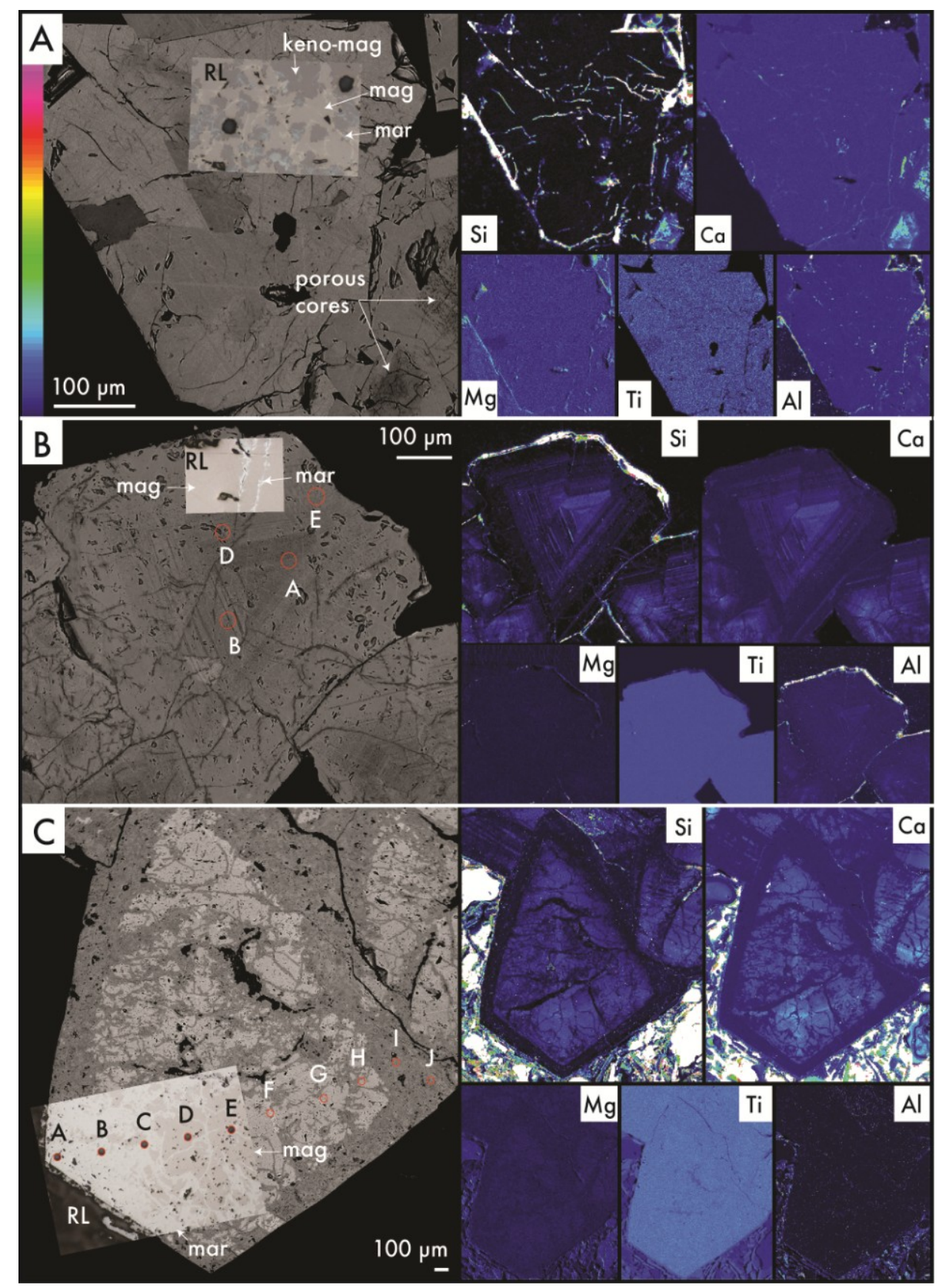

Fig. 5. Back-scattered electron images and chemical X-ray maps of representative Laco Sur ore magnetite. Relative chemical variation scale for X-ray maps in a. Orange circles represent LA-ICPMS spot locations relevant to Fig. 7 and X-ray maps include the whole crystals shown in the BSE image. Direct comparisons in the zoning contrast in BSE cannot be made between each sample because the photographs were taken at different settings to optimize the chemical structure in the magnetite grains. a) ELL-14-04, subhedral-euhedral magnetite grain with clear zoning in BSE imaging and no evident zoning in the X-ray maps for this grain. Adjacent grains with vuggy cores show elevated growth zones of Si, Ca and Al. Reflected light (RL) microscopy shows areas of the grain has been altered to kenomagnetite (keno-mag) and slight martite (mar) replacement along 
fractures. b) ELL-14-05, subhedral-euhedral magnetite grains with clear growth zoning in the BSE image that correlates with the X-ray maps for $\mathrm{Si}, \mathrm{Ca}$ and $\mathrm{Al}$, each element is elevated or depleted in the same layers with increasing concentrations towards the core. RL microscopy shows slight martite replacement along fractures. c) ELL-14-06, euhedral magnetite with clear zoning that correlates with increasing $\mathrm{Si}$ and $\mathrm{Ca}$ towards the core. RL microscopy shows that extensive replacement of the magnetite to martite has occurred, which correlates to very low trace element concentration in the X-ray maps.

(Ramanaidou et al., 2008). Another sample from the upper levels of the ore body (ELL14-05) consists primarily of spongy porous magnetite with $\mathrm{cm}$-sized elongated voids that are lined with 200-600 $\mu \mathrm{m}$ euhedral magnetite crystals. In BSE images, the magnetite crystals have concentric growth zoning with darker central regions. Under reflected light hematite alteration can be seen along fractures in the magnetite and the edges of the magnetite (Fig. 4b). The magnetite from a magnetite vein in the lower level of the ore body (ELL-14-06) has 0.5-2 mm sized magnetite grains that are euhedral along the edge of 0.5-1 cm sized cavities and the magnetite is anhedral elsewhere. In BSE images, the magnetite grains displays a lighter core with darker portions that occurs along fractures and the grain rims (Fig. 4c). Under reflected light the lighter BSE portions of the grain can be identified as magnetite and the darker portions are martite.

The andesite host rock has microphenocrysts of magnetite, $100-200 \mu \mathrm{m}$ in size, that are anhedral and contain trellis texture exsolution lamellae that in BSE images are visibly darker than the magnetite (Fig. 6a). Under reflected light the lamellae were identified as ilmenite. The Láscar dacite has disseminated anhedral magnetite in $<100 \mu \mathrm{m}$ sized grains with local exsolution lamellae, visibly darker in BSE images, but this is not widespread (Fig. 6b). The exsolution lamellae in the Láscar dacite were identified as 
ilmenite with reflected light microscopy, a common texture found in titaniferous magnetite (Mehdilo and Irannajad 2010).

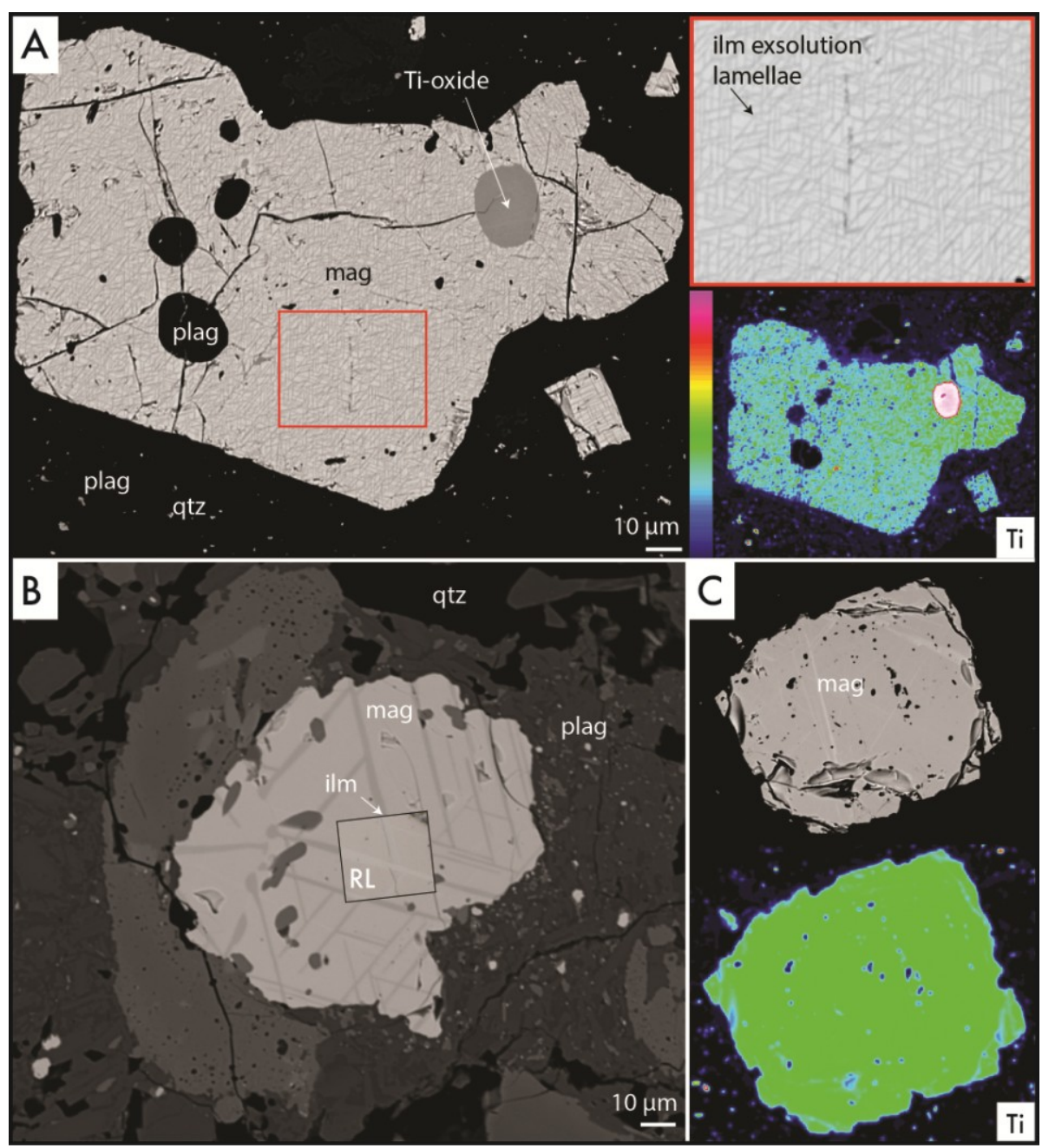

Fig. 6. Back-scattered electron images and chemical X-ray maps of magnetite from the andesite host rock at El Laco volcano and the dacite sample from Láscar volcano. Relative chemical variation scale for X-ray maps in a. a) ELL-14-02 (E1 Laco andesite), andesite with fine trellis textured ilmenite lamellae visible in BSE image and X-ray map for $\mathrm{Ti}$, red box surrounds the magnified view of the exsolution domain. $\mathrm{b}$ and c) LAS-1407 (Láscar dacite), ilmenite exsolution lamellae visible in BSE and RL are found in some grains (b) and are absent in others (c). 


\section{Kiruna magnetite X-ray maps}

Little chemical variation was observed in the X-ray maps for any of the Kiruna magnetite samples. The ore magnetite from the deposits in the Kiruna area display zones of elevated Al and Si that correlate with each other (see Fig. 3b, c and Fig. 4c). Many of the larger $(>100 \mu \mathrm{m})$ ore and host rock magnetite grains display equally distributed spots of elevated $\mathrm{Al}$ throughout the grains that is not observed in the $\mathrm{Si}, \mathrm{V}, \mathrm{Ca}$, or Ti X-ray maps (see Fig. 3b, e and 4a). These elevated Al spots are displayed in BSE images as darker spots (see Fig. 4a). The magnetite from the granite intrusive at Kiirunavaara (Fig. $3 \mathrm{~g}$ ), and the footwall magnetite at Rektorn, display elevated contents of $\mathrm{Si}, \mathrm{Al}, \mathrm{Ca}$, and $\mathrm{Ti}$ can be found along structures that follow the typical shape of spinel exsolution lamellae (Fig. 4e). The syenite sample of the Kiirunavaara mine revealed rims depleted in V (Fig. 3h). The Rektorn ore X-ray map has the most distinct chemical variations due to the presence of hematite that correlates to elevated $\mathrm{Ti}$ and $\mathrm{V}$ found in the zones darker in BSE (see Fig. 4d).

\section{EI Laco magnetite X-ray maps}

The ore magnetite-kenomagnetite crystal from ELL-14-04 that was mapped did not have a porous core that was observed in other grains from that sample and did not show any variation in chemistry. However, the adjacent grains in the X-ray map have porous cores which display elevated $\mathrm{Si}, \mathrm{Ca}$, and $\mathrm{Al}$ with growth zoning (Fig. 5a). The Xray maps of the ELL-14-05 magnetite, with concentric growth zoning visible in BSE imaging, revealed increasing $\mathrm{Si}, \mathrm{Ca}$, and $\mathrm{Al}$ content towards the core of the grain (Fig. 5b). Magnetite grains from a vein in the lower levels of the ore (ELL-14-06) displays growth zoning in $\mathrm{Si}$ and $\mathrm{Ca}$ with highest concentrations in the core. The martite (i.e., 
hematite) replaced portions of the magnetite show lowest concentrations of trace elements (Fig. 5c). The El Laco andesite magnetite grain shows elevated Ti in the ilmenite exsolution lamellae that are visible in BSE imaging and reflected light microscopy (Fig. 6a). The Láscar dacite magnetite grain chosen for the X-ray map shows overall elevated Ti (Fig. 6b) compared to the El Laco magnetite.

\section{Trace element chemistry of Kiruna magnetite}

The iron content of magnetite for the ore, host, and intrusive rocks at Kiruna were slightly lower than the ideal stoichiometric value ( 72.4 wt.\% Fe) with EPMA results ranging from 69.4 and $70.8 \mathrm{wt} . \% \mathrm{Fe}$ (Table 2). The iron content for analyses on samples that were identified as hematite (REK-10-01 and REK-10-04) was distinctly lower than the magnetite and ranged from $63.8-68.5$ wt. $\%$ Fe. All of the magnetite grains from the Kiruna area, including the magnetite-apatite ore, host rocks and related felsic intrusive rocks, are overall chemically homogeneous and contain low trace element concentrations (i.e., $<500 \mathrm{ppm}$ ). The $\mathrm{V}$ concentrations, and locally the Si content, in the magnetite are generally higher than the other trace elements with concentrations around $0.1 \mathrm{wt} \%$ and up to $0.2 \mathrm{wt} \%$. The Ti contents are very low for magnetite with concentrations generally $<50 \mathrm{ppm}$. The Kiirunavaara D-ore magnetite grains have higher Si and V contents than the B-ore magnetite. The degree of alteration seems not to affect the chemical composition of the footwall magnetite at Kiirunavaara; both samples contain similar, and low, trace element concentrations. The hanging wall magnetite at Kiirunavaara has higher Si and lower V compared to the footwall magnetite. The magnetite from the syenite, aplite, and granite intrusive rocks at the Kiirunavaara deposit shows some variation in chemistry; particularly, the syenite magnetite, which has the highest Si content, and the 
aplite magnetite has the highest $\mathrm{V}$ content. The Nukutusvaara ore magnetite grains have higher Ti content than Kiirunavaara, Tuollavaara and Rektorn. The Rektorn ore shows the most chemical variability visible in BSE, X-ray maps and reflected light described earlier; trace element results confirms that the hematite ore contains elevated Ti and V and is depleted in Ni and Ga relative to the magnetite ore (see Fig. 8).

\section{Trace element chemistry of the El Laco magnetite}

The Fe concentrations for the magnetite grains at the Laco Sur ore are 67.25-70.4 wt $\% \mathrm{Fe}$. The magnetite grain that displays concentric growth zoning (ELL-14-05) showed decreasing $\mathrm{Si}, \mathrm{Ca}$ and $\mathrm{Al}$ towards the rim of the grain in the $\mathrm{X}$-ray maps and trace element analysis confirms this (Fig. 7a, see Fig. 5b for analysis locations). In addition, $\mathrm{Mg}$ and $\mathrm{Ce}$ as well as the high field strength elements (HFSE) Y, Nb, and Th and the large ion lithophile elements (LILE) and Sr follow a similar pattern; with a systematic decrease towards the rim. A euhedral magnetite grain from the magnetite vein referred to above (ELL-14-06) was analyzed 10 times across the grain; this produced a chemical cross-section of the grain (Fig. 7b, see Fig. 5c for spot locations). This cross-section shows that the core is enriched in $\mathrm{Si}$ and $\mathrm{Ca}$, already detected in the X-ray maps (see Fig. 5c), as well as $\mathrm{Mn}, \mathrm{Sr}, \mathrm{Y}, \mathrm{Nb}, \mathrm{Ce}$ and Th. Five of the analyses (A, C, F, I and J) were done on magnetite that has been altered to martite and these analyses show lower concentrations of each trace element that defines the zoning patterns in the magnetite. Other trace element concentrations, such as $\mathrm{Ti}, \mathrm{V}, \mathrm{Ni}, \mathrm{Sn}, \mathrm{Ga}$, and $\mathrm{V}$ do not show variations between the pure magnetite and areas replaced by martite (see Fig. 8, 9, 10 and $11)$. 

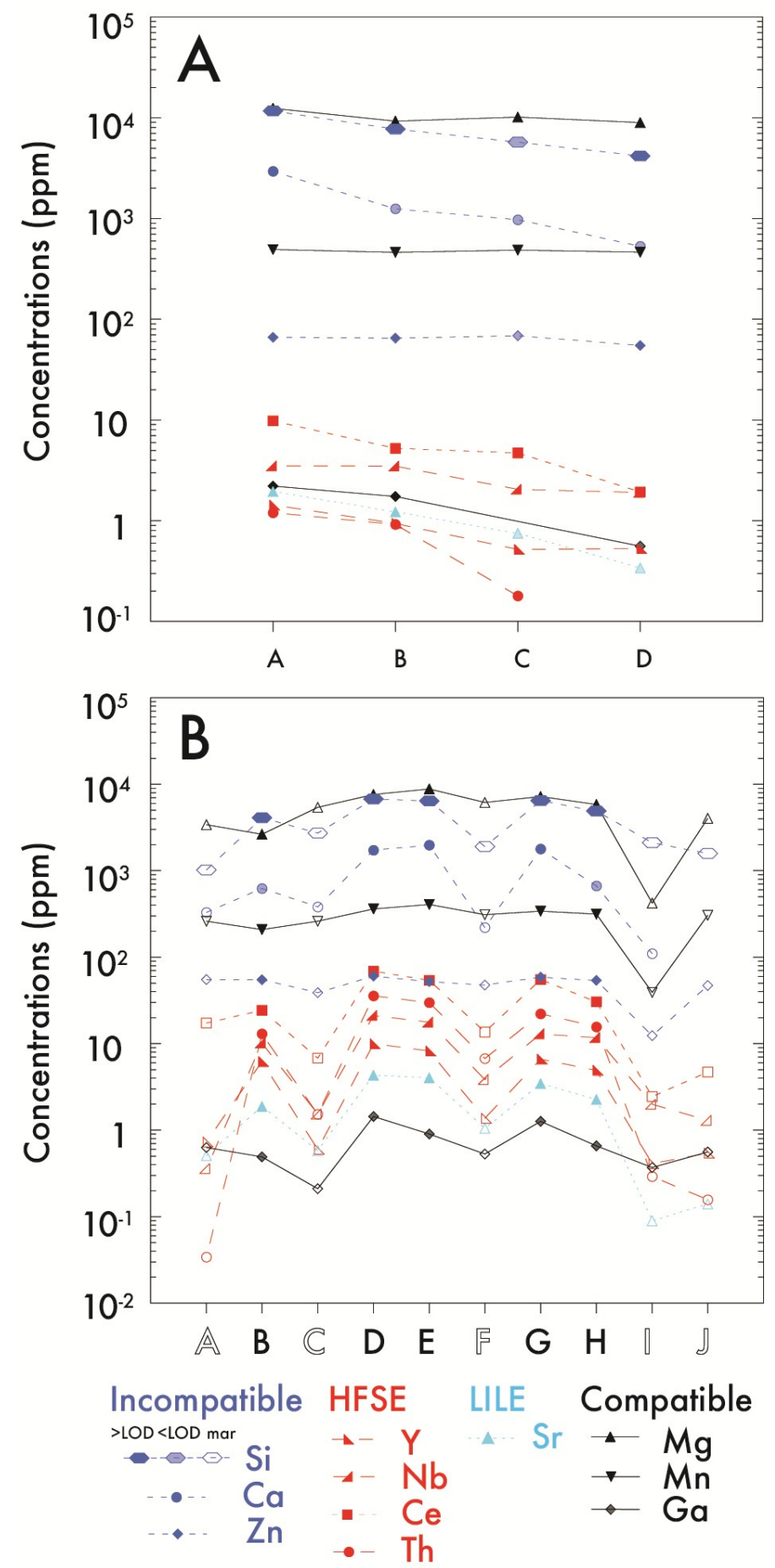

Fig 7. Trace element zoning patterns in magnetite grains from the Laco Sur magnetite ore. a) ELL-14-05 ore sample (see Fig. 5c for laser spot locations) and b) ELL-14-06 ore sample (see figure $5 \mathrm{c}$ for laser spot locations). Faded symbols represent analysis that are $<$ LOD and open symbols are analysis of martite (pseudomorphic replacement of magnetite to hematite). See text for details. 
The host andesite at El Laco and the dacite from the Láscar volcano have lower Fe content with concentrations ranging from 59.4-65.6 wt.\% Fe and 56.8-61.4 wt \% Fe, respectively. This is possibly due to the presence of unavoidable ilmenite exsolution lamellae and overall much higher Ti and other trace element concentrations. The andesite host rock magnetite at El Laco contains elevated concentrations of $\mathrm{Al}, \mathrm{P}, \mathrm{Ti}, \mathrm{V}, \mathrm{Cr}, \mathrm{Mn}$, $\mathrm{Zn}, \mathrm{Nb}$ and $\mathrm{Ba}$ compared to the ore magnetite, a similar pattern to that described by Dare et al. (2015) (see Figure 13). The dacite magnetite from Láscar had the highest trace element content with the addition of elevated $\mathrm{Mg}, \mathrm{Si}, \mathrm{Ca}$ and $\mathrm{Sn}$ compared to the andesite magnetite.

\section{Mineral deposit-type discrimination diagrams}

Loberg and Horndahl (1983) studied the geochemistry of magnetite in different types of iron ores, including magnetite-apatite, titaniferous, and BIF, including samples from the Kiruna and Bergslagen (southeast Sweden) regions and some samples from Iran and Chile. Fe, Ti, V, and Ni, were used to create several discrimination plots. The Ni vs. V diagram (Fig. 8a) show very homogeneous compositions of these two elements for each individual sample, but there are significant variations between samples from each locality and between E1 Laco and Kiruna samples. In contrast, the Ti concentrations are rather heterogeneous and vary considerably even within each sample (Fig. 8b and c). Distinct chemical variations between the Kiirunavaara ore (lowest Ti contents), the Per Geijer ores near Kiruna (highest Ti concentrations), and the El Laco ores are observed. 

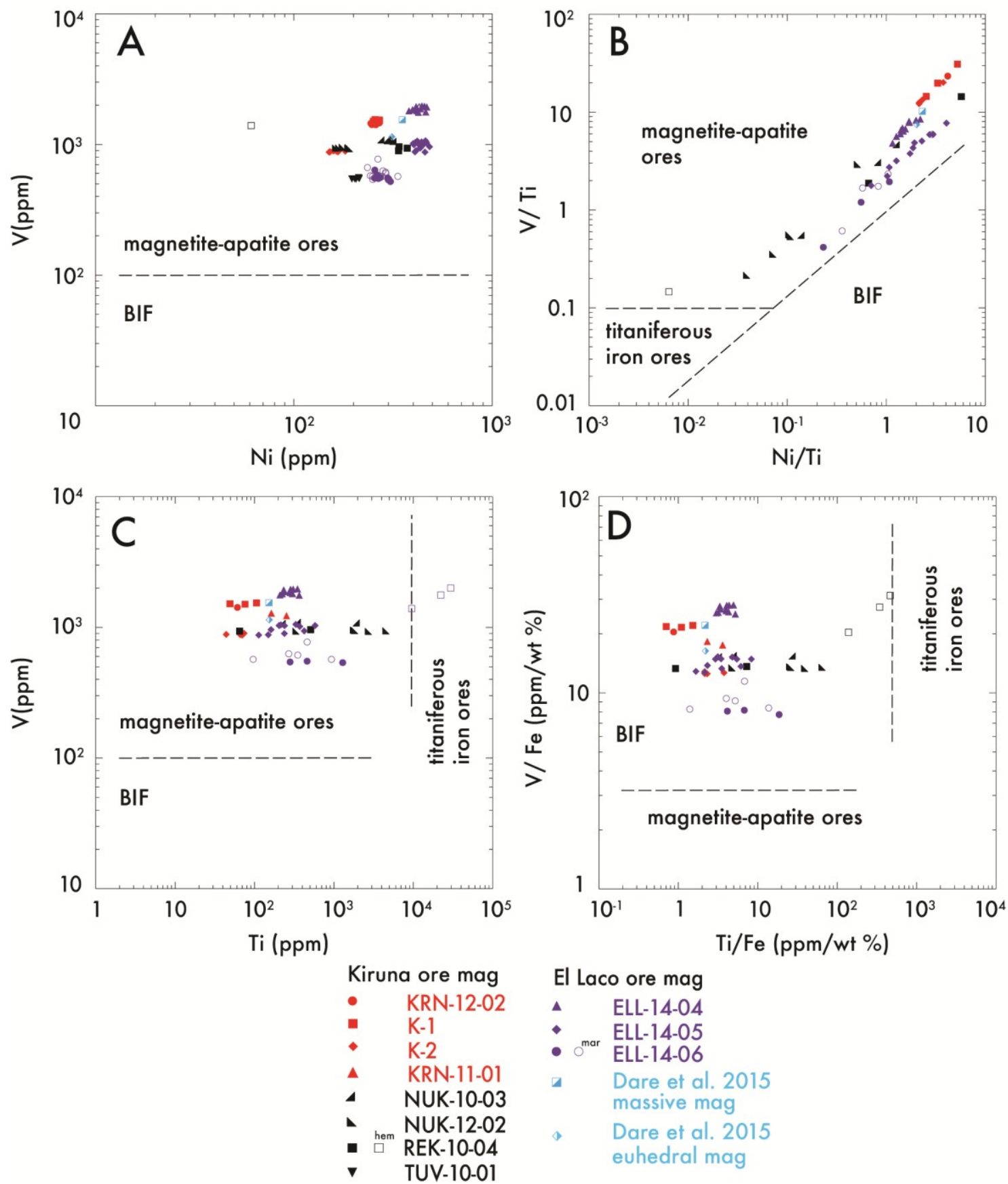

Fig. 8. Magnetite discrimination plots by Loberg and Horndahl (1983) containing fields for magnetite-apatite ores and BIF $(a-d)$ and titaniferous iron ores $(b-d)$ with samples from this study plotted. a) V (ppm) vs. Ni (ppm). b) V/Ti vs. Ni/Ti. c) V (ppm) vs. Ti $(\mathrm{ppm})$ and d) $\mathrm{V} / \mathrm{Fe}(\mathrm{ppm} / \mathrm{wt} \%)$ vs. Ti/Fe (ppm/wt \%). The symbols used here for the ore magnetite are the same for the remaining figures in this paper. The open symbols represent analysis of hematite or martite. See text for details. 
Dupuis and Beaudoin (2011) also proposed several empirical discrimination diagrams for magnetite from various deposit types including BIF, IOCG, magnetiteapatite (Kiruna-type), porphyry-Cu, skarn and Fe-Ti-V layered mafic intrusion deposits (Fig. 9). The two diagrams are based on $\mathrm{Al}+\mathrm{Mn}+\mathrm{Ca}$ (wt \%) (Fig. 9a) and $\mathrm{Ni} /(\mathrm{Cr}+\mathrm{Mn})($ Fig. $9 \mathrm{~b})$ on the $\mathrm{y}$-axis vs. $\mathrm{Ti}+\mathrm{V}(\mathrm{wt} \%)$ on the $\mathrm{x}$-axis. In these plots, the field of the Kiruna-type deposits was based on the analysis of magnetite from seven different magnetite-apatite locations around the world, including Kiruna and El Laco (Dupuis and Beaudoin, 2011). It should be noted that the samples chosen from Kiruna and E1 Laco are different to those used in the present study. These diagrams are suggested for usage during mineral exploration to fingerprint different styles of mineralization using magnetite chemistry. We chose the version of the first diagram (Fig. 9a) modified by Nadoll et al. (2014), who eliminated Ca from the y-axis component, because plotting with or without Ca made little difference in where our data plotted because many of the $\mathrm{Ca}$ contents are low or below the LOD.

In Figure 9a, the majority of the Kiruna and El Laco magnetite analyses from the present study plot below and to the left of the proposed Kiruna field and none of the data plot within that field. Magnetite from the Rektorn ore with elevated Ti plot within the FeTi, V deposit field. Magnetite from the stratabound ore of El Laco, plots non-uniquely in the IOCG and porphyry copper fields, situated above and to the left of the Kiruna-type field.

In Figure 9b, about one third of the magnetite-apatite ore analyses plot within the Kiruna-type field but the majority plots within the IOCG field. The Ti-rich hematite from 
the Rektorn ore plots within the Fe-Ti, V deposit field. The Ti-poor magnetite from the Rektorn ore plots above the IOCG and Kiruna-type fields.
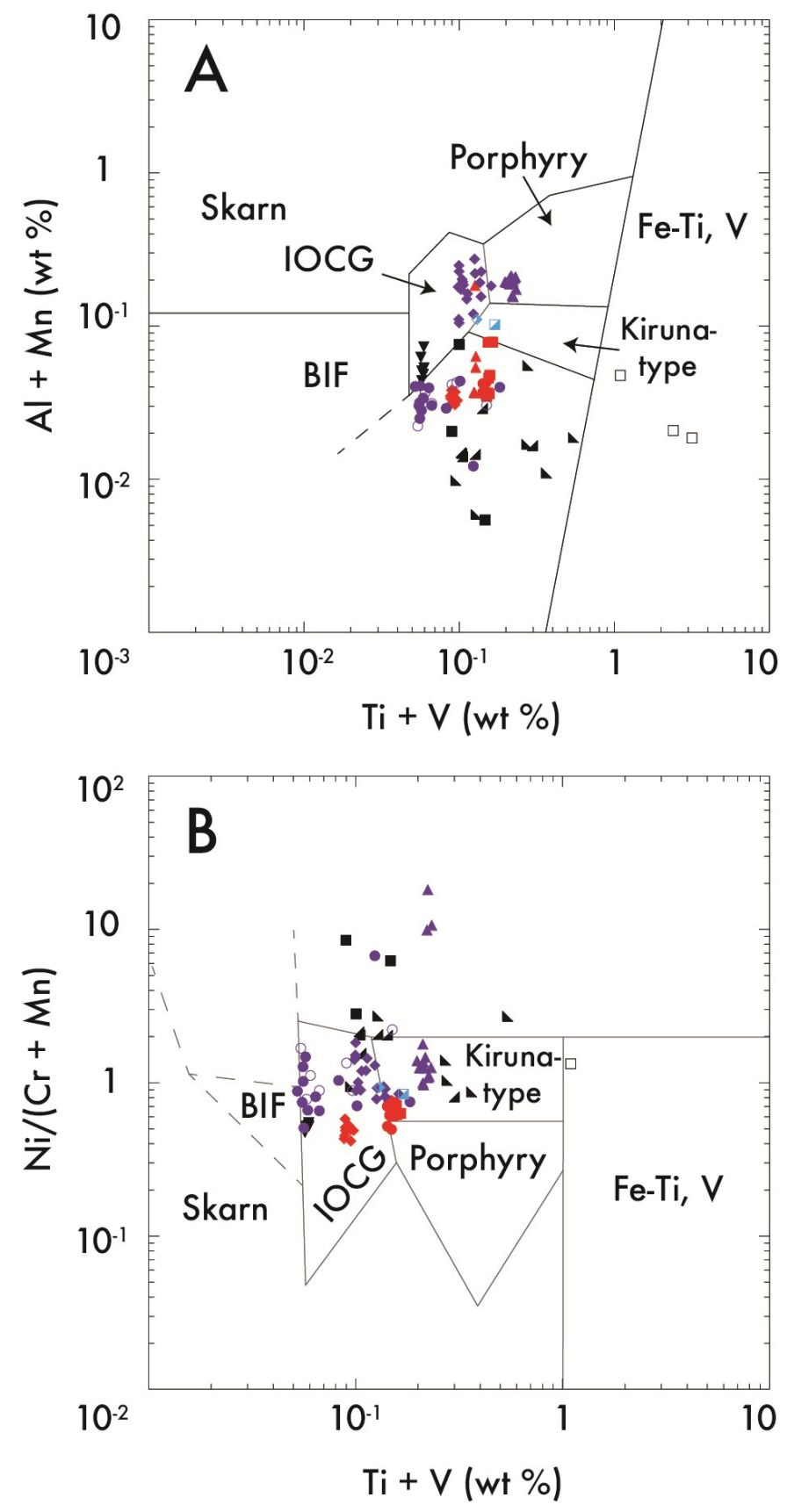

Fig. 9. Magnetite discrimination plots for various ore deposit-types by Dupuis and Beaudoin (2011) and modified by Nadoll et al. (2014) with samples from this study 
plotted. a) $\mathrm{Al}+\mathrm{Mn}($ wt \%) vs. $\mathrm{Ti}+\mathrm{V}($ wt \%). b) Ni/(Cr $+\mathrm{Mn})$ vs. $\mathrm{Ti}+\mathrm{V}$ (wt \%). See text for details.

Knipping et al. (2015) presented a discrimination diagram to distinguish Kirunatype deposits from porphyry, IOCG and Fe-Ti, V deposits based on the $\mathrm{Cr}$ and $\mathrm{V}$ content of the magnetite (Fig. 10). The Kiruna-type deposits were defined as having low $\mathrm{Cr}$ content $(<\sim 100 \mathrm{ppm})$ and high V content $(>\sim 500 \mathrm{ppm})$. Some of the magnetite analyses from the Kiruna and El Laco magnetite-apatite ores in this study have higher Cr content than previously reported (Dare et al., 2015) and plot above the Kiruna-type zone with similar $\mathrm{Cr}$ and $\mathrm{V}$ content as magnetite from IOCG and porphyry deposits.

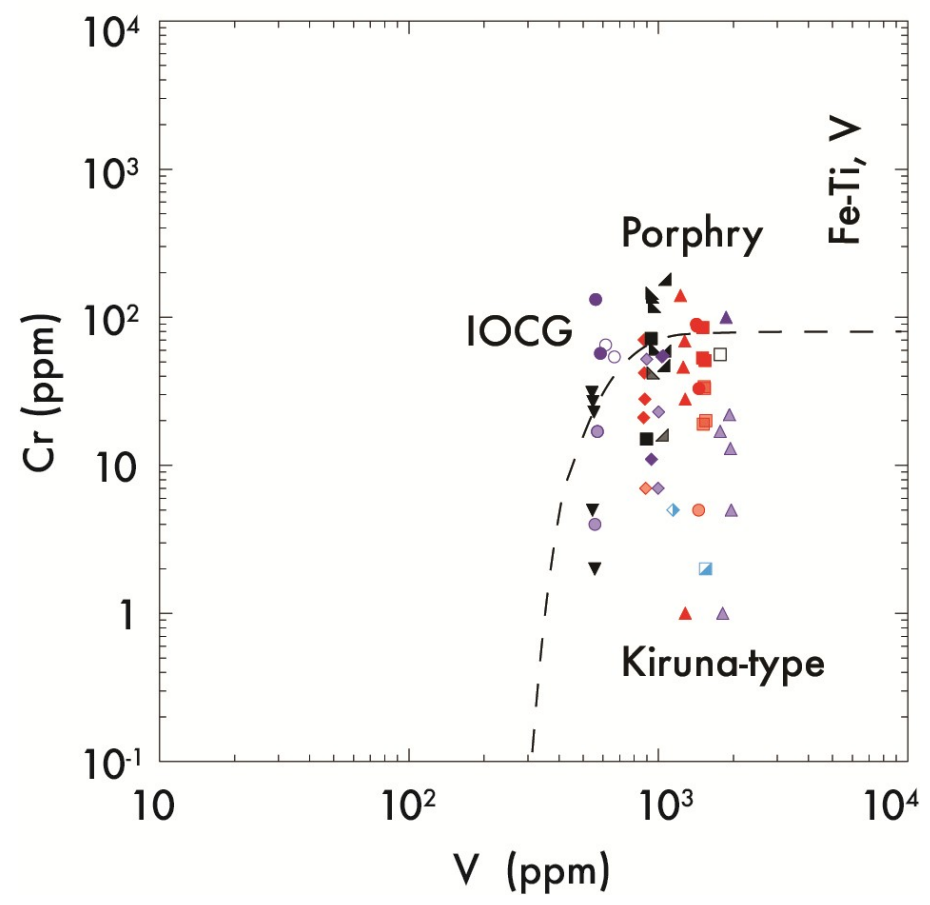

Fig. 10. Cr vs. V plot discriminating Kiruna-type from other ore deposit proposed by Knipping et al. (2015). Many of the magnetite grains from the Kiruna and El Laco magnetite-apatite ores in this study contain higher $\mathrm{Cr}$ concentrations than suggested in this diagram. The faded symbols represent analysis of $\mathrm{Cr}$ that is $<\mathrm{LOD}$. See text for details. 


\section{Magmatic vs. hydrothermal magnetite discrimination diagrams}

Nadoll et al. (2015) proposed using the concentrations of Ti and V in magnetite to distinguish between hydrothermally and magmatically formed magnetite (Fig. 11). The justification for this diagram is that $\mathrm{Ti}$ and $\mathrm{V}$ are often found in high concentrations within magmatic magnetite and low concentrations within hydrothermal magnetite (Nadoll 2015; Knipping et al., 2015). Knipping et al. (2015) used this diagram as well, to support their magmatic-hydrothermal model for the formation of magnetite-apatite deposits, and drew magmatic and hydrothermal fields using magnetite data from Nadoll (2015). This is essentially the same plot used by Loberg and Horndahl (1983), to describe magnetite from magnetite-apatite deposits vs. BIF and titaniferous iron ores (see Fig. 8c), though used here to describe magnetite from different environments.

In Figure 11, magnetite data from the magnetite-apatite ores are plotted with the addition of the host rock magnetite to evaluate the fields drawn by Knipping et al. (2015). Most of the Kiruna magnetite data in the present study do not plot within the magmatic, hydrothermal, or overlapping magmatic-hydrothermal fields. The magnetite from the Kiirunavaara ore and host rocks has very low Ti concentrations that are at or below LOD and plot to the left of the overlapping magnetite-apatite field. The hematite portions of the Rektorn ore, with elevated Ti concentrations, plots in the magmatic magnetite field and the magnetite, with low Ti concentrations, plots in the overlapping field. The footwall magnetite at Rektorn plots within the hydrothermal magnetite field. The stratabound ore magnetite at El Laco plots within the overlapping magnetite-apatite field or to the left of this field. The host andesite magnetite at El Laco and the Láscar dacite magnetite, both with high $\mathrm{Ti}$ and $\mathrm{V}$ concentrations, plot at the far top right of the magmatic field. 


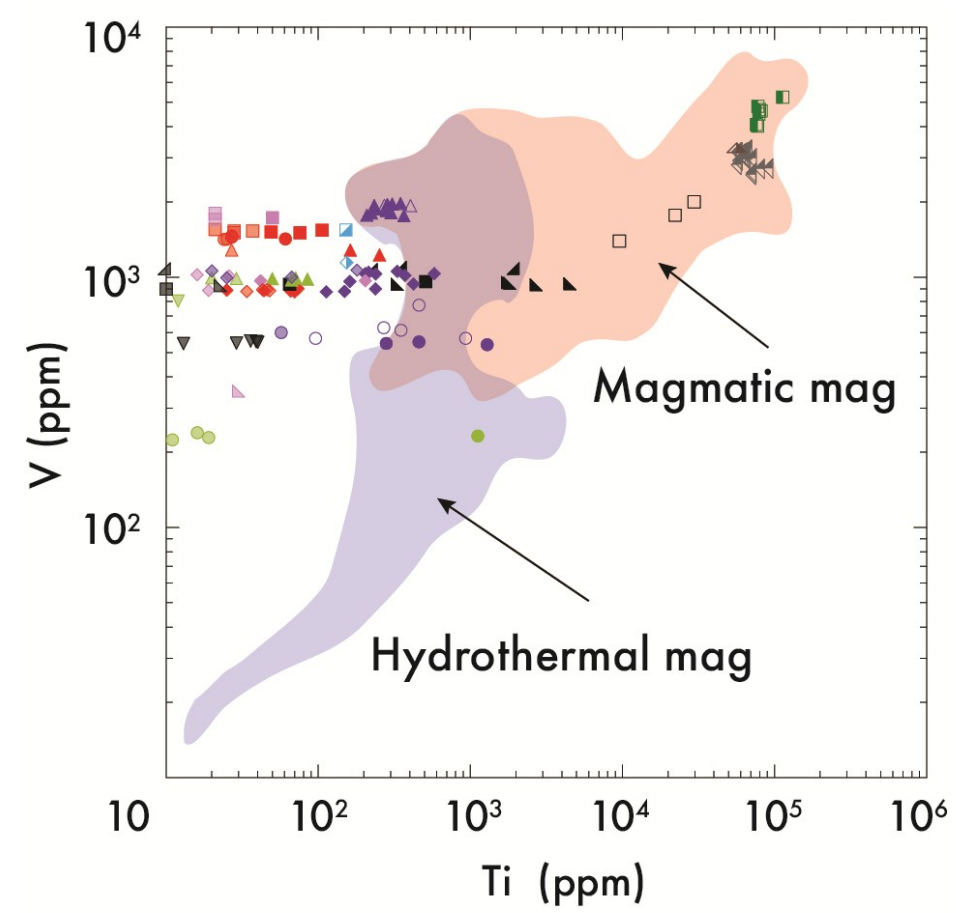

$\begin{array}{cc}\text { Kiruna FW mag } & \text { El Laco host andesite mag } \\ \nabla \text { KRN-11-03 } & 4 \text { ELL-14-02 } \\ \Delta \text { KRN-11-04 } & \Delta \text { Dare et al. 2015 } \\ \text { unaltered andesite } \\ \text { Kiruna HW mag } & \text { Lascar dacite mag } \\ \text { - KRN-11-05 } & \text { D LAS-14-07 } \\ \text { - TUV-10-03 } & \end{array}$

Kiruna felsic intrusive mag

- KRN-12-02

- KRN-12-03

- KRN-12-05

Fig. 11. V vs. Ti plot first proposed by Nadoll et al. (2015) with hydrothermal and magmatic magnetite fields drawn by Knipping et al. (2015). The plot suggests overall higher Ti and $\mathrm{V}$ concentrations in igneous magnetite with considerable overlap in Ti and $\mathrm{V}$ chemistry between hydrothermal and igneous magnetite. The symbols used for magnetite samples of the host rock and related intrusive bodies are the same for the remaining figures in this paper. The faded symbols here represent analysis of Ti that is $<$ LOD. See text for details.

Dare et al. (2014) proposed an empirical discrimination diagram of Ti vs. $\mathrm{Ni} / \mathrm{Cr}$ that shows there is a distinct chemical difference between magnetite that precipitated 
from hydrothermal fluids and magnetite that crystallized from a magmatic melt (Fig. 12). Most of our magnetite data, including the host rock magnetite data for Kiruna, had one or more of the elements required for this plot below LOD. The Kiruna and Laco Sur ore magnetite as well as most of the Kiruna host rock and related intrusive magnetite, which occurs in igneous rocks, plots within the hydrothermal magnetite field proposed by Dare et al. (2014) due to the low $\mathrm{Ti}$ and $\mathrm{Cr}$ content of the magnetite. However, magnetite from

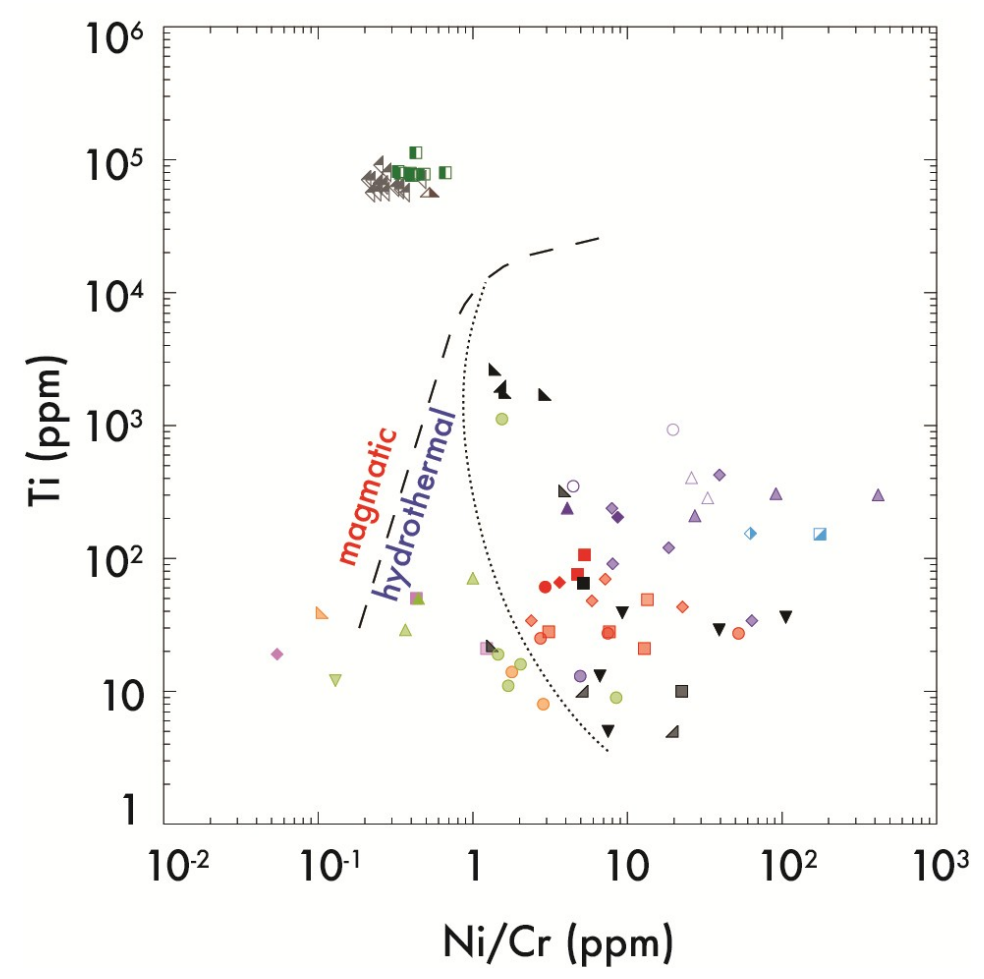

Fig. 12. Samples from this study plotted on the $\mathrm{Ti}$ vs. $\mathrm{Ni} / \mathrm{Cr}$ plot proposed by Dare at al. (2014) to discriminate between magmatic and hydrothermal environments for magnetite formation. The majority of the magnetite data from Kiruna and the ore magnetite from El Laco had either $\mathrm{Ni}, \mathrm{Cr}$ or $\mathrm{Ti}<\mathrm{LOD}$ and these analysis are plotted here as faded symbols. The dotted line, placed in this study, separates the host and intrusive magnetite in Kiruna from the ore magnetite. See text for details. 
the Kiruna host rocks and related intrusive rocks show a distinctly lower $\mathrm{Ni} / \mathrm{Cr}$ ratio compared magnetite from the Kiruna and El Laco ore. A recent detailed study of El Laco by Velasco et al. (2016) showed that massive magnetite from the stratabound ore and the disseminated magnetite related to the early alkaline-calcic alteration, and of undisputable hydrothermal origin, plot in both the magmatic and hydrothermal fields.

Trace element variations for magnetite were plotted on a multi-element diagram proposed by Dare et al. (2014) that was modified in this present study to leave out trace elements not commonly found in magnetite and not measured in this study (e.g., Zr, Ge, W, Sc, and Mo from the Kiruna analyses and Zr, Hf, Sc from the El Laco analyses) (Fig. 13). Elements are normalized to the bulk continental crust data from Rudnick and Gao (2003). This diagram shows there to be distinct trace element chemical patterns between magnetite from a magmatic origin and from magnetite that could be from a high-T or low-T hydrothermal origin. Magmatic magnetite patterns from Dare et al. (2014) are based on data from the El Laco andesite and the Bushveld complex as well as magnetite from I-type granite. The high-temperature hydrothermal $\left(500-700^{\circ} \mathrm{C}\right)$ region was defined using analytical results for magnetite from nine different IOCG deposits. The lowtemperature hydrothermal zone $\left(<500^{\circ} \mathrm{C}\right)$ is based on magnetite from iron-rich skarns, $\mathrm{Ag}-\mathrm{Pb}-\mathrm{Zn}$ veins and BIFs. Average results from each magnetite sample in the present study were used for this plot (Appendix III); this made the diagram easier to read and interpret.

The trace element patterns for the magnetite-apatite ores at Kiruna are most similar to the high-temperature hydrothermal magnetite zone (Fig. 13a). Magnetite within the host and intrusive rocks in Kiruna for the most part follows a similar trace element 

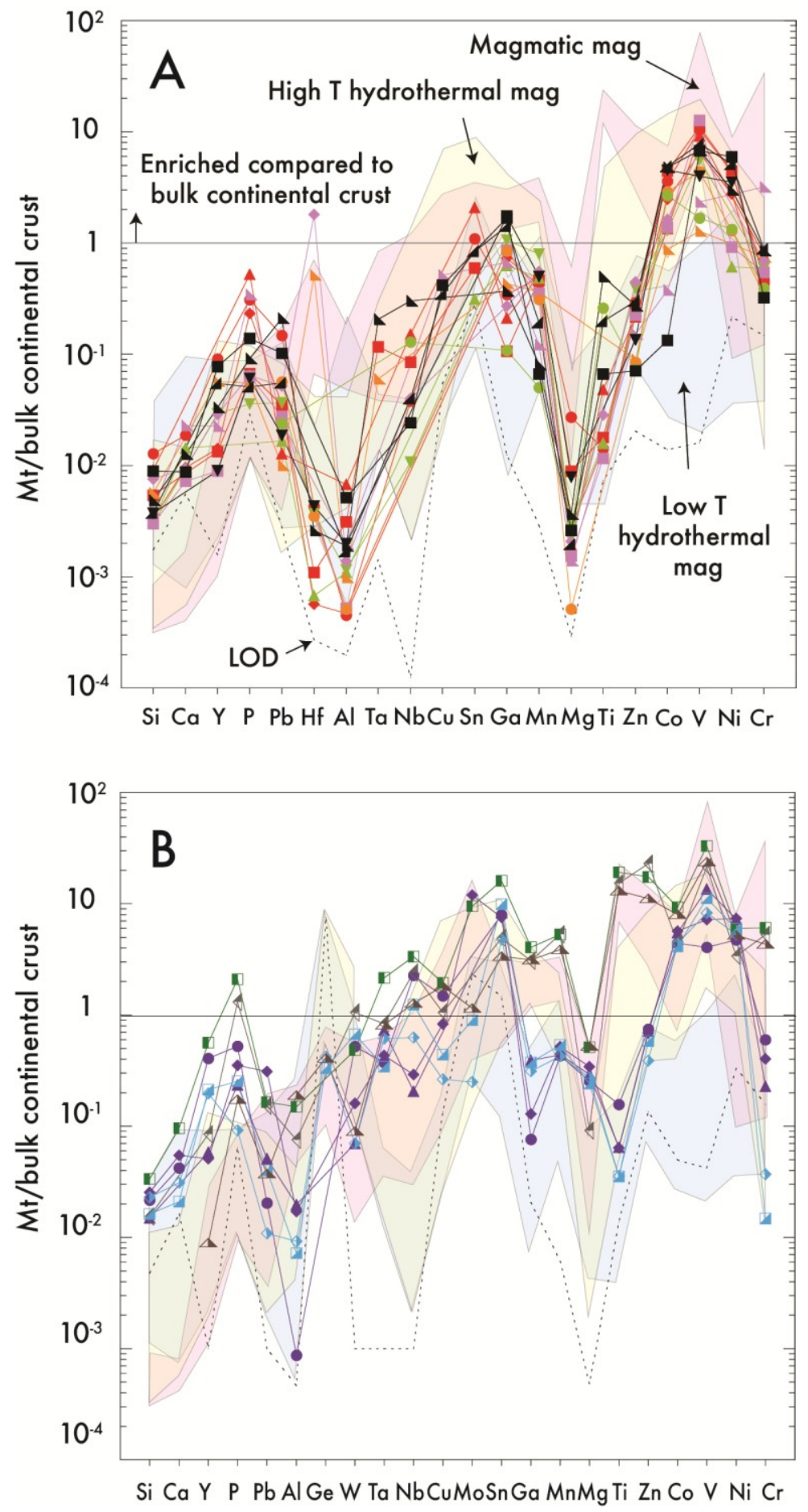

Fig. 13. Samples from this study on a multi-element variation diagram proposed by Dare et al. (2014) showing trace elements in magnetite normalized to bulk continental crust from Rudnick and Gao (2003). Zones showing the proposed compositional patterns of magnetite from magmatic (pink), high- (yellow) and low- (blue) temperature hydrothermal environments are shown. Each zone was adjusted in this study to accommodate elements that were not analyzed. See text for details. 
pattern to the ore magnetite, in the high-temperature hydrothermal zone, though with overall lower trace element concentrations than the ore magnetite. None of the host magnetite at Kiruna resembles the proposed magmatic trend even though they are hosted in volcanic rocks, except peaks in $\mathrm{Hf}$ in magnetite from the Kiirunavaara hanging wall and the syenite sill in the footwall at Kiirunavaara.

The trace element patterns for the Laco Sur ore magnetite show similar trends as the high-temperature hydrothermal pattern, with high $\mathrm{Mg}$ trending into the magmatic field and low Ga trending into the low-temperature hydrothermal field (Fig. 13b). The andesite host rock magnetite at El Laco and the Láscar dacite magnetite follow the magmatic magnetite trend. All magnetite from El Laco and Láscar analyzed in the present study, including the andesite and dacite magnetite, shows higher concentrations of $\mathrm{Si}, \mathrm{Ca}, \mathrm{Y}$ and $\mathrm{P}$ than what is typical of the magnetite zones proposed in this plot, with the volcanic dacite magnetite containing the highest concentrations of these elements.

\section{Discussion}

The trace element geochemistry of magnetite depends on the content of the element in the fluid, melt or aqueous, source and the capability of the host mineral to accept the trace element in its structure, which can depend on variables such as the temperature or the redox state. Thus, discrimination diagrams could only be used when the host mineral is not saturated in the contained element and there is no competing phases that could host it; otherwise, the trace element composition should be controlled by the partitioning coefficient $\left(\mathrm{K}_{\mathrm{D}}\right)$ between both minerals. Also, drop in the temperature or fluctuating conditions can lead to exsolution of separate phases, which also has to also be taken into account. Furthermore, the accurate use of discrimination diagrams should 
also exclude the presence of nanoinclusions, which cannot always be removed during the LA-ICPMS data reduction.

\section{The use of mineral deposit-type discrimination diagrams}

The Loberg and Horndahl (1983) diagrams (see Fig. 8) worked effectively plotting the magnetite-apatite ores within the appropriate fields. These diagrams contain very broad discrimination fields, which accounts for the chemical variation observed in the ore magnetite. In the case of the Rektorn ore, a higher Ti concentration in the hematite ore suggests that this ore body formed at higher temperatures and more reducing conditions (see Lindsley, 1976) or from a source richer in Ti. Regardless, the data suggest that this mineralization had a different genesis or a source of different composition, or both, from the other magnetite-apatite ores at Kiruna.

The Dupuis and Beaudoin (2011) diagrams (see Fig. 9) have narrow discrimination fields. The magnetite-apatite data from this study do not plot within the proposed Kiruna-type discrimination field and overlapped significantly with other deposit types such as IOCG and porphyry-Cu. There is too much overlap in magnetite chemistry from the Kiruna-type magnetite-apatite mineralization and the other types of deposits for this diagram to work effectively. For instance, if these diagrams were to be used in mineral exploration using magnetite as an indicator mineral it would be impossible to distinguish magnetite sourced from magnetite-apatite ores from magnetite from IOCG or $\mathrm{Cu}$-porphyry deposits. Thus, and based on the results from the present study, the Kiruna field needs to be significantly modified or removed from the diagram. Since many of the magnetite-apatite ore analyses plot within the IOCG field, this could have implications 
for a common connection between these two styles of mineralization, or alternatively, could reveal a flaw in the reasoning behind the rationale for these diagrams.

The Knipping et al. (2015) $\mathrm{Cr} / \mathrm{V}$ discrimination diagram was used to fingerprint how Kiruna-type deposits have distinct $\mathrm{Cr}$ and $\mathrm{V}$ contents from porphyry, IOCG, and $\mathrm{Fe}$ Ti, V deposits (see Fig. 10). The rationale behind the Kiruna-type field in this diagram is that higher $\mathrm{V}$ content relates to the high formational temperatures. The low $\mathrm{Cr}$ content of Kiruna-type magnetite is explained by its high $\mathrm{K}_{\mathrm{D}}$ into the fractionation of augite or, and deemed more likely, the high mobility of the $\mathrm{Cr}^{6+}$ into oxidized fluids that transported $\mathrm{Cr}$ out of the magnetite-apatite ore forming system. As mentioned above in the results, several of the magnetite analyses from the Kiruna and El Laco ores in this study have higher $\mathrm{Cr}$ contents than previously reported for those localities (Dare et al., 2015). Assuming the rationale behind the diagram is valid, then higher $\mathrm{Cr}$ content observed in the ore magnetite in the present study suggests $\mathrm{Cr}$, and possibly other elements that are mobile in hydrothermal fluids such as $\mathrm{Si}, \mathrm{Ca}$ and LILE, were not transported out of the system but were incorporated into the magnetite.

\section{The use of magmatic vs. hydrothermal magnetite discrimination diagrams}

Nadoll et al. (2015), further used by Knipping et al. (2015), used V and Ti concentrations to discriminate between magmatic and hydrothermal magnetite (see Fig. 11). Based on the magnetite data from the present study, and those of Velasco et al. (2016), it is clear that magnetite from the magnetite-apatite deposits has extremely variable $\mathrm{V}$ and $\mathrm{Ti}$ concentrations. Thus, many of the magnetite samples here plot outside the fields on this diagram, questioning the integrity of the plot. Dare et al. (2014) proposed another diagram that discriminates between magmatic and hydrothermal 
magnetite using $\mathrm{Ti}$ and $\mathrm{Ni} / \mathrm{Cr}$ concentrations (see Fig. 12). Although the magnetite from magnetite-apatite ores plot within the hydrothermal magnetite field, this does not necessarily verify that they formed hydrothermally, as has been shown by Velasco et al. (2016). Probably, these empirical diagrams are too simple to distinguish and the Ti and $\mathrm{Ni} / \mathrm{Cr}$ ratios do not only depend on the precipitation from silicate or aqueous fluids or needs additional constraints and/or adjustments.

Magnetite that crystallized from a melt of unique composition may contain lower Ti concentrations than is normal for igneous magnetite. The multi-element variation diagrams proposed by Dare et al. (2014) have fields that overlap significantly with each other and none of the analyses from the present study plot perfectly within one field, leaving ambiguity regarding the utility of that diagram (see Fig. 13). Furthermore, it must be considered that it is not possible to directly compare the trace element patterns between immiscible melts, such as a silicate melt and a presumable iron rich-melt, since during phase separation, the $\mathrm{K}_{\mathrm{D}}$ irregularly distributes the elements between them.

\section{Magnetite chemistry at Kiruna}

The magnetite studied from the Kiruna magnetite-apatite ores is generally very homogenous and shows few textural and chemical variations. It is strongly suggested that the original trace element chemistry of the magnetite in the Kiruna ore and their host rocks were affected by subsequent hydrothermal alteration and metamorphism. The rocks at Kiruna have undergone widespread hydrothermal alteration (Westhues et al., 2016) and up to greenschist facies metamorphism (Bergman et al., 2001); where widespread recrystallization of magnetite can occur (Dahl 1979). The X-ray maps of the Kiruna magnetite grains revealed areas of increased Si and Al that often are correlated with each 
other. These zones are blotchy and random and could likely be a result of metasomatic alteration. The high-Al domains are most prominent in the larger grains of the ore and footwall magnetite could be nanoinclusions of an Al-rich mineral or may also be the result of metasomatic alteration.

Hydrothermal titanite is widespread in the Kiruna ore (Romer et al., 1994; Storey et al., 2007) and indicates that the hydrothermal fluids were rich in Ti. Titanite has been dated to be just younger, though with overlapping error (1876 $\pm 9 \mathrm{Ma}$, Romer et al., 1994) than the volcanic rocks around Kiirunavaara (1890 \pm 90 Ma, Cliff et al., 1990). Recent in situ dating confirmed these time constraints and it is suggested that the titanite ages reflect the metasomatic alteration overlapping with the ore formation (Westhues et al., 2016).

Although the magnetite chemistry of the Kiruna rocks are very similar in most elements (see Fig. 11 and 13), the Ni/Cr vs Ti plot after Dare et al. (2014) (see Fig. 12) revealed, a distinct difference in the $\mathrm{Ni} / \mathrm{Cr}$ content of the magnetite from the magnetiteapatite ores and the host rocks/related felsic intrusive rocks: The latter have a more similar Ni/Cr content as the El Laco host rocks but with lower Ti concentrations. This may suggest that, before subsequent intensive alteration of the host rocks, primary magnetite may have had a more similar composition to the magnetite in andesite at El Laco. Because the chemistry of the magnetite studied in the rocks at Kiruna show indications of being subsequently altered by metasomatism, it is difficult to draw any conclusive arguments on how the magnetite-apatite ores formed through the utilization of magnetite discrimination diagrams. 


\section{Magnetite chemistry at EI Laco}

The magnetite from El Laco is much younger than at Kiruna and has not been affected by metamorphism, but most of it likely has undergone various degrees of hydrothermal alteration (Tornos et al., 2016). There are clear chemical differences at El Laco in the magnetite ore and magnetite from the andesite host and the dacite sample from the nearby Láscar Volcano. The andesite and dacite samples have similar trace element chemistry with signatures that plot as igneous magnetite on proposed discrimination diagrams (see Figs. 10, 11 and 12) and have clear exsolution textures common in Ti-rich magmatic magnetite crystallized in hot and reduced settings (Mehdilo and Irannajad 2010). The Láscar dacite magnetite has elevated trace element concentrations compared to the El Laco andesite magnetite. This may indicate that the source melt of the volcanic rocks at Láscar has a different composition from the El Laco volcanic rocks or certain physicochemical parameters were different such as lower $f \mathrm{O}_{2}$ of the melt at Láscar during magnetite crystallization.

The ore magnetite at El Laco shows clear zonation patterns in BSE and X-ray maps, which have also been described by previous authors (Fig. 5) (e.g., Velasco and Tornos 2011; Dare et al., 2015; Velasco et al., 2016). The centers of the magnetite crystals show elevated concentrations of Si, Ca and LILE (Fig. 7) compared to the outer regions; these elements are considered to be incompatible and highly mobile in hydrothermal environments (Dare et al., 2014; Nadoll et al., 2014). However, the cores also show elevated concentrations of $\mathrm{Mg}, \mathrm{Al}$ and $\mathrm{Mn}$, elements that are considered compatible and generally immobile in hydrothermal fluids as well as $\operatorname{HFSE}$ (Y, Nb, Ce and $\mathrm{Th}$ ), which are incompatible during partial melting but not as readily mobile in hydrothermal environments (McCulloch and Gamble 1991, Blake 1992). Also, the ore 
magnetite were reported as being "enriched" in elements that are highly mobile in hydrothermal fluids, though concentrations of these elements are not higher than was detected in the unaltered andesite magnetite or the Láscar dacite magnetite (see Fig. 13 and Appendix III).

If the El Laco ores formed through metasomatic replacement of the andesite host rocks as proposed by Dare et al. (2015), one would expect elevated LILE concentrations in the magnetite; however, the HFSE and especially incompatible elements are not readily mobile in hydrothermal fluids and one would expect them to be in lower concentrations than the LILE and not behaving the same way during magnetite crystallization. Dare et al. (2014) describes iron-rich skarn magnetite as having element concentrations and euhedral zoning similar to the El Laco magnetite. However, the elements that define growth zones in the iron-rich skarn magnetite are not enriched and depleted in the same layers, suggesting quick changes in the composition of the igneous/aqueous fluid pulses that crystallized the magnetite. Also, elements such as V and $\mathrm{Ni}$ are zoned in the iron-rich skarn magnetite (Dare et al., 2014) and this is not observed in the E1 Laco magnetite suggesting not all elements were fluctuating during magnetite growth, as would be the case during growth from hydrothermal fluids.

Looking closely at the zoning chemistry of the El Laco ore magnetite, a combination of incompatible elements, compatible elements, LILE and HFSE behave the same way during magnetite crystal growth (i.e., they are all found either elevated or depleted in the same layers). Formation of magnetite from a crystallizing iron oxide melt at El Laco is consistent with the presence of magmatic textures, the stable isotope geochemistry and the presence of melt inclusions with evidences of melt immiscibility; it 
is also difficult to envisage the circulation of iron-rich hot brines at shallow depths (Tornos et al., 2016). Thus, the chemistry of the magnetite at El Laco can be explained by magnetite crystallizing from an iron-rich melt that is initially enriched in the elements involved in the zonation patterns with periodic replenishment from the source melt during magnetite growth with less replenishment over time. Or, and more likely, the crystallization of magnetite during fluctuating redox conditions $\left(f \mathrm{O}_{2}\right)$, fluid content and temperature of the melt. As the iron-rich melt moved closer to the surface the system would have shifted from a reduced environment to an oxidized environment. In an

oxidized system there is an increase of $\mathrm{Fe}^{3+}$, which occupies octahedral sites in magnetite, inhibiting the incorporation of other elements, such as $\mathrm{Ti}$, that were present in the iron-rich melt (Buddington and Lindsley 1964). It should also be noted that spherical to spheroidal magnetite particles have been described from more friable ore than the samples used in the study, textures that can only be explained by rapid cooling of an ironrich melt (Henríquez and Martin 1978; Nyström et al., 2016).

\section{Conclusions}

After a critical evaluation of empirical magnetite discrimination diagrams using newly obtained data on the trace element composition of magnetite from precisely known geographic and geologic locations (encompassing the Kiruna and El Laco magnetiteapatite ores and their associated hydrothermally altered host rocks) the following conclusions can be drawn for practical usage in determining the environment from which magnetite crystallized (i.e., hydrothermal or magmatic):

1) Only the earlier diagrams by Loberg and Horndahl (1983), with very broad discrimination fields, allowed effectively plotting the magnetite-apatite ores within the 
appropriate field. The more recent discrimination diagrams proposed by Dupuis and Beaudoin (2011) and Knipping et al. (2015), with more constrained fields, need to be adjusted if they are to include the Kiruna-type magnetite;

2) The $\mathrm{Cr}$ content from Kiruna-type magnetite reached higher concentrations than previously reported by Knipping et al. (2015), this calls into questions the validity of the $\mathrm{Cr}-\mathrm{V}$ plot as well as conclusions drawn from using this plot to support the genetic model for magnetite-apatite deposits that is proposed by these authors;

3) The magmatic vs. hydrothermal discrimination diagram for magnetite by Knipping et al. (2015) needs modification as many of the data from the present study did not plot within either of the proposed fields;

4) The magmatic vs. hydrothermal magnetite diagram by Dare et al. (2014) had limited use because most of the data collected had non-detectable $\mathrm{Cr}, \mathrm{Ni}$, or $\mathrm{Ti}$ concentrations. The data below LOD, however, had to be plotted in order to evaluate this diagram. The indisputably igneous magnetite (e.g., El Laco andesite and Láscar dacite) effectively plotted within the magmatic magnetite field. The magnetite-apatite ores from El Laco and Kiruna and host rock magnetite at Kiruna all plot within the hydrothermal field. The host rock magnetite has distinctly lower $\mathrm{Ni} / \mathrm{Cr}$ ratio than magnetite from the magnetite-apatite ores.

5) The multi-element variation diagrams proposed by Dare et al. (2014) only work if the magnetite-apatite ores are actually of hydrothermal origin, and do not work on magnetite that has undergone subsequent metamorphism and/or metasomatic alteration such as at Kiruna. 
After reviewing the chemistry and textures of the magnetite from the Kiruna and El Laco magnetite-apatite ores and their host rocks the following conclusions can be made:

1) It is likely that the magnetite at Kiruna is largely influenced by subsequent metamorphism and/or metasomatic alteration. Whether the magnetite-apatite ores, which show hydrothermal signatures on the diagrams discussed above, originated from hydrothermal fluids or formed later through post-ore metamorphic or metasomatic alteration cannot be determined using magnetite chemistry alone; and

2) The magnetite from magnetite-apatite ores at El Laco have chemical zonations that appear similar to Fe-rich skarns (Dare et al., 2015), though there are very distinct differences in the zonation patterns. Observations of the chemical zonation patterns in the El Laco magnetite that do not correlate with iron-rich skarn magnetite include: a) The El Laco ore magnetite has zonations of compatible, LIL and HFS elements that are all elevated or depleted in the same crystal layers; and, b) some compatible elements are homogenous across the magnetite grains (i.e., V and Ni). With these observations, we propose the magnetite at El Laco is indicative of having crystallized from a volatile-rich iron-oxide melt that was fluctuating in physiochemical conditions rather than from replacement of the host rocks by pulses of hydrothermal fluids.

\section{Acknowledgements}

We would like to thank the Natural Sciences and Engineering Research Council of Canada (NSERC) discovery grant to JMH. The contribution of FT has been funded by the project SEIDI 2014 CGL2014-55949-R. Thanks to LKAB and Compañía Minera del Pacífico for help in logistics, and permission to sample and granting access to the mine 
sites. We thank the reviewers (P. Williams and N. Oliver) for thorough and constructive

criticism of the original manuscript. Thanks also to B. Lehmann for his review and editorial additions, and handling of this paper.

\section{References}

Alva-Vadivia LM, Rivas ML, Goguitchaichvili A, Urrutia-Fucugauchi J, Gonzalez JA, Morales J, Gómez S, Henríquez F, Nyström JO, Naslund RH (2003) Rock-magnetic and oxide microscopic studies of the El Laco ore deposits, Chilean Andes, and implications for magnetic anomaly modeling. International Geology Review 45:533-547

Barton MD, Johnson DA (1996) Evaporitic-source model for igneous-related Fe oxide-(REE-Cu-Au-U) mineralization. Geology 24:259-262

Barton MD, Johnson DA (2004) Footprints of Fe-oxide(-Cu-Au) systems. SEG 2004: Predictive Mineral Discovery Under Cover. Centre for Global Metallogeny, Spec Pub 33:112-116

Bergman S, Kubler L, and Martinsson O (2001) Description of regional geological and geophysical maps of northern Norrbotten County (east of the Caledonian Orogen). Sveriges Geologiska Undersokning 56:110

Blake KL (1992) The petrology, geochemistry and association to ore formation of the host rocks of the Kiirunavaara magnetite-apatite deposit, northern Sweden. PhD thesis. University of Wales College of Cardiff

Buddington AF, Lindsley DG (1964) Iron-titanium oxide minerals and synthetic equivalents. J Petrol 5(2):310-357

Chamberlain SC, Robinson GW, Lupulescu M, Morgan TC, Johnson JT, deLorraine WB (2008) Cubic and tetrahexahedral magnetite. Rocks \& Minerals 83(3):224-239. Doi: 10.3200/RMIN.83.3.224-239

Crohn PW, Moore DH (1984) The Mud Tank carbonatite, Strangways Range, central Australia. Journal of Australian Geology \& Geophysics 9:13-18

Dahl PS (1979) Comparative geothermometry based on major-element and oxygen isotope distributions in precambrian metamorphic rocks from southwestern Montana. American Mineralogist 64:12801293

Dare SAS, Barnes S-J, Beaudoin G, Méric J, Boutroy E, Potvin-Doucet C (2014) Trace elements in magnetite as petrogenetic indicators. Miner Deposita 49:785-796

Dare SAS, Barnes S-J, Beaudoin G (2015) Did the massive magnetite "lava flows" of El Laco (Chile) form by magmatic or hydrothermal processes? New contraints from magnetite composition by LA-ICPMS. Miner Deposita 50:607-617

Dupuis C, Beaudoin G (2011) Discriminant diagrams for iron oxide trace element fingerprinting of mineral deposit types. Miner Deposita 46:319-335.

Dymek RF, Owens BE (2001) Petrogenesis of apatite-rich rocks (nelsonites and oxide-apatite gabbronorites) associated with massif anorthosites: Econ Geol 96:797-815 
Edfelt A, Armstrong RN, Smith M, Martinsson O (2005) Alteration paragenesis and mineral chemistry of the Tjarrojakka apatite-rion and $\mathrm{Cu}(-\mathrm{Au})$ occurrences, Kiruna area, northern Sweden. Miner Deposita 40:409-434

Frietsch R (1978) On the magmatic origin of iron ores of the Kiruna type. Econ Geol 73:478-485

Frietsch R, Perdahl Jan-Anders (1995) Rare earth elements in apatite and magnetite in Kiruna-type iron ores and some other iron ore types. Ore Geology Reviews 9:489-510

Geijer P (1910) Igneous rocks and iron ores of Kiirunavaara, Luossavaara and Tuollavaara. Scientific and practical researches in Lapland arranged by the Luossavaara-Kiirunavaara Aktiebolag - Geology of the Kiruna district, 2: Stockholm, p. 278

Geijer P (1919) Recent developments at Kiruna, SGU, C 288, p. 23

Grigsby JD (1990) Detrital magnetite as a provenance indicator. Journal of Sedimentary Petrology 60(6):940-951

Groves DI, Bierlein FP, Meinert LD, Hitzman MW (2010) Iron oxide copper-gold (IOCG) through earths history: implications for origin, lithospheric setting, and distinction from other epigenic iron oxide deposits. Econ Geol 105:641-654

Hall JM, Fisher BE (1987) The characteristics and significance of secondary magnetite in a profile through the dike component of the Troodos, Cyprus, ophiolite. Canadian Journal of Earth Science 24:2141-2159

Hallberg A, Bergman T, Gonzalez J, Larsson D, Morris GA, Perdahl JA, Ripa M, Niiranen T, Eilu P (2012) Metallogenic areas in Sweden. Survey of Finland, Special Paper 53:139-206

Harlov DE, Andersson UB, Forster H-J, Nyström JO, Dulski P, Broman C (2002) Apatite-monazite relations in the Kiirunavaara magnetite-apatite ore, northern Sweden. Chemical Geology 191:4772

Henríquez F, Martin RF (1978) Crystal growth textures in magnetite flows and feeder dykes, El Laco, Chile, Can Miner 16:581-589

Hildebrand RS (1986) Kiruna-type deposits - their origin and relationship to intermediate subvolcanic plutons in the Great Bear magmatic zone, northwest Canada: Econ Geol 81:640-659

Hitzman MW, Oreskes N, Einaudi MT (1992) Geological Characteristics and Tectonic Setting of Proterozoic Iron-Oxide (Cu-U-Au-Ree) Deposits. Precambrian Research 58:241-287

Jochum KP, Willbold M, Raczek I, Stoll B, Herwig K (2005) Chemical characterisation of the USGS reference glasses GSA-1G, GSC-1G, GSD-1G, GSE-1G, BCR-2G, BHVO-2G and BIR-1G using EPMA, ID-TIMS, ID-ICP-MS and LA-ICP-MS. Geostandards and Geoanalytical Research 29(3):285-302

Knipping JL, Bilenker LD, Simon AC, Reich M, Barra F, Deditius AP, Wälle M, Heinrich CA, Holtz F, Munizaga R (2015) Trace elements in magnetite from massive iron oxide-apatite deposits indicate a combined formation by igneous and magmatic-hydrothermal processes. Geochim Cosmochim Acta $171: 15-38$

Lindsley DH (1976) The crystal chemistry and structure of oxide minerals as exemplified by the Fe-Ti oxides. In Oxide minerals. Mineralogical Society of America, Short Course Notes 3:L-1 to L-60 
Lindsley DH (1991) Oxide minerals: petrologic and magnetic significance. Reviews in Mineralogy, Volume 25, Stony Brook, New York, USA

LKAB (2015) Annual and sustainability report. http://www.lkab.com/en/. Accessed 30 April 2016

Loberg BEH, Horndahl A-K (1983) Ferride geochemistry of swedish precambrian iron ores. Miner Deposita 18:487-504

Martinsson O (1994) Greenstone and porphyry hosted ore deposits in northern Norbotten, NUTEK report nr 92-00752P: Luleå, p. 31.

Martinsson O (2004) Geology and metallogeny of the northern Norrbotten Fe-Cu-Au province: Society of Economic Geologists, Guidebook Series 33:131-148

Martinsson O, Billström K, Broman C, Weihed P, Wanhainen C (2016) Metallogeny of the northern Norrbotten ore province, northern fennoscandian shield with emphasis on IOCG and apatite-iron ore deposits. Ore Geology Reviews. doi: 10.1016/j.oregeorev.2016.02.011

McCulloch MT, Gamble JA (1991) Geochemical and geodynamical constraints on subduction zone magmatism. Earth and Planetary Science Letters 102:358-374

Mehdilo A, Irannajad M (2010) Applied mineralogical studies on iranian hard rock titanium deposit. Journal of Minerals \& Material Characterization \& Engineering 9(3):247-262

Mucke A, Younessi R (1994) Magnetite-Apatite Deposits (Kiruna-Type) Along the Sanandaj-Sirjan Zone and in the Bafq Area, Iran, Associated with Ultramafic and Calcalkaline Rocks and Carbonatites: Mineralogy and Petrology 50:219-244

Muller B, Axelsson MD, Bjorn O (2003) Trace elements in magnetite from Kiruna, northern Sweden, as determined by LA-ICP-MS. GFF 125:1-5

Nadoll P, Angerer T, Mauk JL, French D, and Walshe J (2014) The chemistry of hydrothermal magnetite: a review. Ore Geology Reviews 61:1-32

Naranjo JA, Henríquez F, Nyström JO (2010) Subvolcanic contact metasomatism at El Laco Volcanic Complex, Central Andes. Andean Geology 37:110-120

Naslund HR, Henríquez FJ, Nyström JO, Vivallo W, Dobbs F (2002) Magmatic iron ores and associated mineralization: examples from the Chilean High Andes and Coastal Cordillera; in Porter, T.M. (Ed.), Hydrothermal Iron Oxide Copper-Gold \& Related Deposits: A Global Perspective, PGC Publishing, Adelaide, 2:207-226

Nyström JO, Henríquez F (1994) Magmatic features of iron ores of the Kiruna type in Chile and Sweden; ore textures and magnetite geochemistry. Econ Geol 89:820-839

Nyström JO, Billström K, Henríquez F, Fallick AE, Naslund H R (2008) Oxygen isotope composition of magnetite in iron ores of the Kiruna type in Chile and Sweden. Gff 130:177-188

Nyström JO, Henríquez F, Naranjo JA, Naslund HR (2016) Magnetite spherules in pyroclastic iron ore at El Laco, Chile. Am Mineral 101:587-595

Paton C, Hellstrom J, Paul B, Woodhead J, Hergt J (2011) Iolite: Freeware for the visualisation and processing of mass spectrometric data. Journal of Analytical Atomic Spectrometry 26:2508-2518. doi: $10.1039 / \mathrm{c} 1 \mathrm{ja} 10172 \mathrm{~b}$ 
Parák T (1975) Kiruna iron ores are not 'intrusive-magmatic ores of the Kiruna type'. Econ Geol 70:12421258

Park CF (1961) A magnetite "flow" in northern Chile. Econ Geol 56:431-436

Pollard PJ (2006) An intrusion-related origin for $\mathrm{Cu}-\mathrm{Au}$ mineralization in iron-oxide-copper-gold (IOCG) provinces. Miner Deposita 41:179-187

Philpotts AR (1967) Origin of certain iron-titanium oxide and apatite rocks. Econ Geol 62:303-315

Ramanaidou E, Wells M, Belton D (2008) Mineralogical and microchemical methods for the characterization of high-grade banded iron formation-derived iron ore. SEG Reviews 15:129-156

Rhodes AL, Oreskes N (1999) Oxygen isotope composition of magnetite deposits at El Laco, Chile: evidence of formation from isotopically heavy fluids. Soc of Econ Geol, Spec Pub 7:333-351

Richards JP, Mumin AH (2013) Magmatic-hydrothermal processes within an evolving Earth: Iron oxidecopper-gold and porphyry $\mathrm{Cu} \pm \mathrm{Mo} \pm \mathrm{Au}$ deposits. Geology 41:767-770

Rudnick R, Gao S (2003) Composition of the continental crust. Treatise Geochem 3:1-64

Sabet-Mobarhan-Talab A, Alinia F, Ghannadpour S-S, Hezarkhani A (2015) Geology, geochemistry, and some genetic disscussion of the Chador-Malu iron oxide-apatite deposit, Bafq District, Central Iran. Arab J Geosci 8:8399-8418

Sillitoe RH, Burrows DR (2002) New field evidence bearing on the origin of the el laco magnetite deposit, northern Chile. Econ Geol 97:1101-1109

Sillitoe RH (2003) Iron oxide-copper-gold deposits: an Andean view. Miner Deposita 38:787-812. doi: $10.1007 / \mathrm{s} 00126-003-0379-7$

Tassi F et al. (2009) The magmatic- and hydrothermal-dominated fumarolic system at the active crater of Láscar volcano, northern Chile. Bull Volcanol 71:171-183

Tornos F, Velasco F, Hanchar JM (2016) Iron oxide melts, magmatic magnetite and superheated magmatichydrothermal systems: the El Laco deposit, Chile. Geology, 44(6):427-430

Valley PM, Fisher CM, Hanchar JM, Lam R, and Tubrett M (2010) Hafnium isotopes in zircon: A tracer of fluid-rock interaction during magnetite-apatite ("Kiruna-type") mineralization. Chemical Geology 275:208-220

Valley PM, Hanchar JM, Whitehouse MJ (2011) New insights on the evolution of the Lyon mountain granite and associated Kiruna-type magnetite-apatite deposits, Adirondack Mountains, New York State. Geosphere 7:357-389

Velasco F, Tornos F (2012) Insights on the effects of the hydrothermal alteration in the El Laco magnetite deposit (Chile). Revista de la Sociedad Española de Mineralogía 16:210-211

Westhues A, Hanchar JM, Whitehouse MJ, Martinsson O (2016) New constraints on the timing of host rock emplacement, hydrothermal alteration and iron oxide apatite mineralization in and around Kiruna, Norrbotten region, northern Sweden. Econ Geol, in press

Williams PJ, Hedenquist JW, Barton MD, Johnson DA, Fontbote L, de Haller A, Mark G, Oliver NHS, Marschik R, Thompson JFH, Goldfarb RJ, Richards JP (2005) Iron oxide copper-gold deposits; geology, space-time distribution, and possible modes of origin. Econ Geol 100:371-405 
Magnetite-apatite ore mineralization has been a subject of debate for over a century and it continues to remain unclear whether they are of hydrothermal or magmatic origin, or a combination of those two processes (e.g., Geijer, 1910; Geijer, 1919; Parák, 1975; Frietsch, 1978; Nyström and Henríquez, 1994; Dare et al., 2014; Tornos et al., 2016). My research contributes to the understanding of how magnetite-apatite ore crystallized at El Laco and Kiruna specifically and possibly other localities through interpretation of the trace element content of magnetite.

Magnetite can incorporate a wide range of trace elements, with distinctive chemical characteristics depending on the crystallizing environment in which it formed. The specific trace element characteristics of magnetite from the various crystallizing environments are not yet well known. Previous authors have proposed various empirical discrimination diagrams to delineate the magnetite chemistry from different types of deposits and crystallizing environments. My research presents new magnetite trace element geochemistry data from the magnetite-apatite deposits in Kiruna, Sweden, and El Laco, Chile, and their respective host rocks as well as magnetite from three different crystallizing environments. The magnetite chemistry was used in this study to critically evaluate the proposed discrimination diagrams for their general use and determine whether magnetite chemistry can be used to determine the crystallizing environment (i.e., hydrothermal or magmatic) of magnetite-apatite deposits. The following conclusions were drawn from this study:

1) From the mineral deposit-type magnetite discrimination diagrams tested in this study only the earlier diagrams by Loberg and Horndahl (1983), worked for effectively 
plotting the magnetite-apatite ores within the appropriate field. The more recent empirical discrimination diagrams proposed by Dupuis and Beaudoin (2011) and Knipping et al. (2015), with more tightly constrained fields, need to be modified if they are to include the Kiruna-type magnetite.

2) The magmatic vs. hydrothermal diagrams tested in this study did not help in determining the mineralizing environment of magnetite-apatite deposits. The magnetite discrimination diagram proposed by Knipping et al. (2015) needs modification as many of the data from the present study did not plot within either of the proposed fields. We believe that the magmatic vs. hydrothermal magnetite diagram by Dare et al. (2014) is too simple to distinguish the crystallizing environment of magnetite because the $\mathrm{Ti}$ and $\mathrm{Ni} / \mathrm{Cr}$ ratios do not only depend on the precipitation from silicate or aqueous fluids. The diagram was also not entirely useful since most of the magnetite analyzed has $\mathrm{Cr}$, $\mathrm{Ti}$ or Ni content at or below the LOD. The multi-element variation diagrams proposed by Dare et al. (2014) only work if the magnetite-apatite ores are actually of hydrothermal origin, and do not work on magnetite that have undergone subsequent metamorphism and/or metasomatic alteration such as at Kiruna.

3) Based on the trace element results of the magnetite in Kiruna it is likely that the grains are mostly influenced by subsequent metamorphism and/or metasomatic alteration by hydrothermal fluids because primary textures and unique chemical signatures do not appear to be present. Therefore, conclusions on the crystallizing environment of the magnetite-apatite ores in Kiruna cannot be made using the magnetite chemistry. At El Laco however, the magnetite shows internal chemical zonation that are indicative of having crystallized from a volatile-rich iron oxide melt rather than directly as a 
precipitate from hydrothermal fluids. This interpretation is based on unique differences in the chemical zonations of the magnetite-apatite ore magnetite at El Laco and the chemical zonations found in iron-rich skarn magnetite presented by Dare et al. (2014).

\section{References}

Dare SAS, Barnes S-J, Beaudoin G, Méric J, Boutroy E, and Potvin-Doucet C (2014) Trace elements in magnetite as petrogenetic indicators. Miner Deposita 49:785-796

Dupuis C, Beaudoin G (2011) Discriminant diagrams for iron oxide trace element fingerprinting of mineral deposit types. Miner Deposita 46:319-335.

Frietsch R (1978) On the magmatic origin of iron ores of the Kiruna type. Econ Geol 73:478-485

Geijer P (1910) Igneous rocks and iron ores of Kiirunavaara, Luossavaara and Tuollavaara. Scientific and practical researches in Lapland arranged by the Luossavaara-Kiirunavaara Aktiebolag - Geology of the Kiruna district, 2: Stockholm, p. 278

Geijer P (1919) Recent developments at Kiruna, SGU, C 288, p. 23

Knipping JL, Bilenker LD, Simon AC, Reich M, Barra F, Deditius AP, Wälle M, Heinrich CA, Holtz F, and Munizaga R (2015) Trace elements in magnetite from massive iron oxide-apatite deposits indicate a combined formation by igneous and magmatic-hydrothermal processes. Geochim Cosmochim Acta 171:15-38

Loberg BEH, and Horndahl A-K (1983) Ferride geochemistry of swedish precambrian iron ores. Miner Deposita 18:487-504

Nyström JO, and Henríquez F (1994) Magmatic features of iron ores of the Kiruna type in Chile and Sweden; ore textures and magnetite geochemistry. Econ Geol 89:820-839

Parák T (1975) Kiruna iron ores are not 'intrusive-magmatic ores of the Kiruna type'. Econ Geol 70:12421258 
Appendix I. Sample list with GPS location, underground level (Kiruna samples) or Elevation (El Laco and Láscar samples), rock type, mineralogy and magnetite textures.

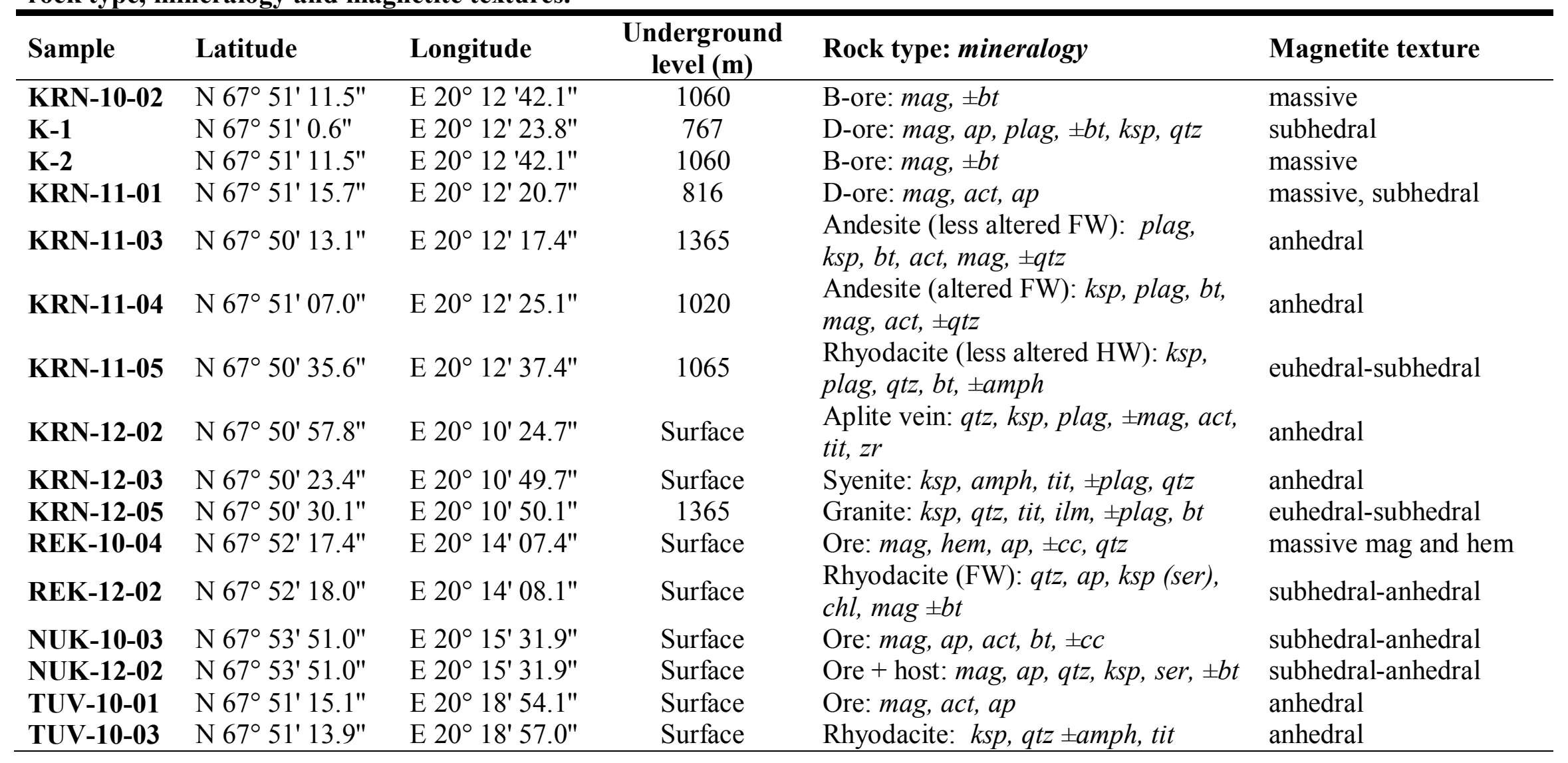


Appendix I. (continued)

\begin{tabular}{|c|c|c|c|c|c|}
\hline Sample & Latitude & Longitude & Elevation (m) & Rock type: mineralogy & Magnetite texture \\
\hline ELL-14-02 & $\mathrm{S} 23^{\circ} 49^{\prime} 5.9^{\prime \prime}$ & W $67^{\circ} 29^{\prime} 40.2^{\prime \prime}$ & 4814 & Andesite (host): plag, cpx, $\pm q t z, \operatorname{mag}$ & $\begin{array}{l}\text { anhedral, micro-ilmenite } \\
\text { exsolution in BSE }\end{array}$ \\
\hline ELL-14-04 & $\mathrm{S} 23^{\circ} 15^{\prime} 14.4^{\prime \prime}$ & W $67^{\circ} 29^{\prime} 22.2^{\prime \prime}$ & 5404 & Vuggy ore: mag, keno-mag \pm mar & $\begin{array}{l}\text { massive, euhedral lining } \\
\text { voids, extensive alteration } \\
\text { to keno-mag, } \\
\text { porous cores with growth } \\
\text { zoning }\end{array}$ \\
\hline ELL-14-06 & $\mathrm{S} 23^{\circ} 50^{\prime} 33.8^{\prime \prime}$ & W $67^{\circ} 29^{\prime} 22.2^{\prime \prime}$ & 4653 & Vein ore: $m a g \pm m a r$ & $\begin{array}{l}\text { massive and subhedral- } \\
\text { euhedral lining voids, } \\
\text { extensive alteration to } \\
\text { martite, mag growth zoning }\end{array}$ \\
\hline LAS-14-07 & $\mathrm{S} 23^{\circ} 22^{\prime}$ & $\mathrm{W} 67^{\circ} 43^{\prime}$ & base of volcano & $\begin{array}{l}\text { Dacite (Volcanic ejecta): plag, cpx, } \\
\pm q t z, \text { mag }\end{array}$ & $\begin{array}{l}\text { anhedral, some ilmenite } \\
\text { exsolution in BSE }\end{array}$ \\
\hline
\end{tabular}

Notes: KRN/K: Kiirunavaara, REK: Rektorn, NUK: Nukutusvaara, TUV: Tuollavaara, FW: footwall, HW: hanging wall; ELL: El Laco volcano, Laco Sur deposit; LAS: Láscar volcano;

Mineral abbreviations: $m a g=$ magnetite, hem=hematite, mar=martite, keno-mag=kenomagnetite, $a p=$ apatite, $b t=$ biotite, $q t=$ quartz, plag=plagioclase, $k s p=\mathrm{k}$-feldspar, $a c t=$ actinolite, $h b l=$ hornblende, $a m p h=$ amphibole, $i l m=$ ilmenite, $t i t=$ titanite, $c c=c a l c i u m$ carbonate, ser $=$ sericite, $c h l=$ chlorite, $z r=$ zircon, $c p x=$ clinopyroxene 
Appendix II. Summarized methods for EPMA Fe analysis and LA-ICPMS trace element analyses of magnetite.

\begin{tabular}{ll}
\hline EPMA & \\
\hline Model & JEOL JXA-8230 Superprobe \\
Voltage & $15 \mathrm{kV}$ \\
Current & $100 \mathrm{nA}$ \\
Spot size & $3 \mu \mathrm{m}$ \\
Peak counting time & $10 \mathrm{~s}$ \\
Background counting time & $20 \mathrm{~s}$ \\
Primary standard & Astimex magnetite \\
Secondary standards used: & Balmat, Mud Tank, and BC-28 natural magnetite \\
Element X-ray line & Fe (K $)$ \\
Analyzing crystal & LiFH \\
\hline LA-ICPMS & \\
\hline Model & Thermo-Finnigan ELEMENT XR coupled with \\
& a GeoLas 193 nm Excimer laser system \\
Pulse frequency & $8 \mathrm{~Hz}$ \\
Energy density & $3 \mathrm{~J} / \mathrm{cm}{ }^{2}$ \\
Spot size & $30-59 \mu \mathrm{m}$ depending on sample and \\
& trace element concentration. \\
Gas blank & $30 \mathrm{~s}$ \\
Signal & $60 \mathrm{~s}$ \\
Internal standard & Fe (EPMA) \\
Primary reference material & NIST-610 \\
Secondary reference & BCR-2G; Balmat, Mud Tank, BC-28 natural \\
material & magnetite \\
\hline
\end{tabular}


Appendix III. Average (mean) LA-ICP-MS (ppm) and EPMA (Fe wt \%) results for trace elements used in plots from Kiruna and EI Laco/Láscar magnetite samples. Minimum level of detection (LOD) calculated by Iolite reported for each analysis session.

\begin{tabular}{|c|c|c|c|c|c|c|c|c|c|}
\hline & $\begin{array}{c}\text { Kiruna } \\
\text { Min LOD }\end{array}$ & $\begin{array}{c}\text { KRN-10-02 } \\
\mathrm{N}=6\end{array}$ & $\begin{array}{l}\mathbf{K}-\mathbf{1} \\
\mathrm{N}=7\end{array}$ & $\begin{array}{l}\mathbf{K}-2 \\
\mathrm{~N}=9\end{array}$ & $\begin{array}{c}\text { KRN-11-01 } \\
\mathrm{N}=7\end{array}$ & $\begin{array}{c}\text { KRN-11-03 } \\
\mathrm{N}=5\end{array}$ & $\begin{array}{c}\text { KRN-11-04 } \\
\mathrm{N}=7\end{array}$ & $\begin{array}{c}\text { KRN-11-05 } \\
\mathrm{N}=2\end{array}$ & $\begin{array}{c}\text { KRN-12-02 } \\
\mathrm{N}=3\end{array}$ \\
\hline $\mathrm{Fe}$ & EPMA & 69.7 & 69.6 & 70.0 & 70.2 & 70.3 & 70.3 & 69.9 & 69.7 \\
\hline${ }^{24} \mathrm{Mg}$ & 8.20 & 764 & 249 & 78.4 & 54.4 & 64.8 & 89.5 & $<\mathrm{LOD}$ & 43.3 \\
\hline${ }^{27} \mathrm{Al}$ & 16.59 & 38.0 & 263 & 39.4 & 569 & 97.3 & 92.3 & 83.0 & 44.0 \\
\hline${ }^{29} \mathrm{Si}$ & 496.60 & 3620 & 1530 & 947 & 2590 & 850 & 908 & 1600 & 850 \\
\hline${ }^{31} \mathrm{P}$ & 16.49 & 175 & 38.0 & 132 & 297 & 20.3 & $<\mathrm{LOD}$ & 31.0 & 36.0 \\
\hline${ }^{44} \mathrm{Ca}$ & 254 & 860 & $<\mathrm{LOD}$ & 440 & $<\mathrm{LOD}$ & $<\mathrm{LOD}$ & 660 & $<\mathrm{LOD}$ & 330 \\
\hline${ }^{47} \mathrm{Ti}$ & 31.6 & 61.0 & 77.0 & 63.5 & 209 & $<\mathrm{LOD}$ & 68.3 & $<\mathrm{LOD}$ & 50.0 \\
\hline${ }^{51} \mathrm{~V}$ & 2.21 & 1439 & 1526 & 886 & 1264 & 772 & 986 & 176 & 1744 \\
\hline${ }^{52} \mathrm{Cr}$ & 19.9 & 70.0 & 63.0 & 46.7 & 105 & 79.2 & 79.7 & 101 & 73.5 \\
\hline${ }^{55} \mathrm{Mn}$ & 2.25 & 378 & 362 & 321 & 400 & 615 & 376 & 280 & 275 \\
\hline${ }^{59} \mathrm{Co}$ & 0.37 & 95.5 & 118 & 66.0 & 35.8 & 34.6 & 43.4 & 23.3 & 36.9 \\
\hline${ }^{60} \mathrm{Ni}$ & 12.8 & 256 & 261 & 163 & $<\mathrm{LOD}$ & $<\mathrm{LOD}$ & 35.9 & $<\mathrm{LOD}$ & 54 \\
\hline${ }^{63} \mathrm{Cu}$ & 1.48 & $<\mathrm{LOD}$ & $<\mathrm{LOD}$ & $<\mathrm{LOD}$ & $<\mathrm{LOD}$ & $<\mathrm{LOD}$ & $<\mathrm{LOD}$ & $<\mathrm{LOD}$ & $<\mathrm{LOD}$ \\
\hline${ }^{66} \mathrm{Zn}$ & 1.47 & 21.0 & 17.3 & 16.0 & 15.6 & 28.4 & 17.2 & 6.45 & 16.2 \\
\hline${ }^{71} \mathrm{Ga}$ & 0.20 & 5.52 & 1.70 & 11.7 & 3.40 & 17.0 & 10.0 & 6.94 & 13.8 \\
\hline${ }^{88} \mathrm{Sr}$ & 0.24 & 1.52 & 1.16 & 1.28 & $<\mathrm{LOD}$ & 2.2 & 1.16 & $<\mathrm{LOD}$ & 1.39 \\
\hline${ }^{89} \mathrm{Y}$ & 0.03 & 1.72 & 0.25 & 0.27 & $<\mathrm{LOD}$ & 0.56 & $<\mathrm{LOD}$ & 1.09 & 0.17 \\
\hline${ }^{93} \mathrm{Nb}$ & 0.06 & 0.30 & 0.68 & $<\mathrm{LOD}$ & 1.22 & 0.09 & $<\mathrm{LOD}$ & $<\mathrm{LOD}$ & $<\mathrm{LOD}$ \\
\hline${ }^{118} \mathrm{Sn}$ & 0.48 & 1.86 & 1.02 & $<\mathrm{LOD}$ & 3.55 & $<\mathrm{LOD}$ & 0.53 & $<\mathrm{LOD}$ & $<\mathrm{LOD}$ \\
\hline${ }^{140} \mathrm{Ce}$ & 0.001 & 7.57 & 0.58 & 2.67 & 0.31 & 0.24 & 0.23 & 0.10 & 0.21 \\
\hline${ }^{178} \mathrm{Hf}$ & 0.001 & 0.02 & 0.00 & 0.00 & $<\mathrm{LOD}$ & 0.01 & 0.00 & 1.91 & $<\mathrm{LOD}$ \\
\hline${ }^{181} \mathrm{Ta}$ & 0.001 & $<\mathrm{LOD}$ & 0.08 & $<\mathrm{LOD}$ & $<\mathrm{LOD}$ & $<\mathrm{LOD}$ & $<\mathrm{LOD}$ & 0.04 & $<\mathrm{LOD}$ \\
\hline${ }^{208} \mathrm{~Pb}$ & 0.03 & 1.63 & 0.38 & 0.39 & 0.14 & 0.40 & 0.18 & 0.11 & 0.31 \\
\hline${ }^{232} \mathrm{Th}$ & 0.001 & 1.23 & 0.11 & 0.57 & 0.02 & 0.01 & 0.05 & 0.10 & 0.01 \\
\hline
\end{tabular}


Appendix III. (continued)

\begin{tabular}{|c|c|c|c|c|c|c|c|c|c|}
\hline $\begin{array}{l}\text { Element } \\
\text { or } \\
\text { isotope }\end{array}$ & $\begin{array}{c}\text { KRN-12-03 } \\
\text { mag } \\
\mathrm{N}=7\end{array}$ & $\begin{array}{c}\text { KRN-12-05 } \\
\text { mag } \\
\mathrm{N}=2\end{array}$ & $\begin{array}{c}\text { TUV-10-01 } \\
\text { mag } \\
\mathrm{N}=6\end{array}$ & $\begin{array}{c}\text { TUV-10-03 } \\
\text { mag } \\
\mathrm{N}=2\end{array}$ & $\begin{array}{c}\text { NUK-10-03 } \\
\text { mag } \\
\mathrm{N}=6\end{array}$ & $\begin{array}{c}\text { NUK-12-02 } \\
\text { mag } \\
\mathrm{N}=6\end{array}$ & $\begin{array}{c}\text { REK-10-04 } \\
\text { mag } \\
N=3\end{array}$ & $\begin{array}{c}\text { REK-10-04 } \\
\text { hem } \\
\mathrm{N}=3\end{array}$ & $\begin{array}{c}\text { REK-12-02 } \\
\text { mag } \\
\mathrm{N}=6\end{array}$ \\
\hline $\mathrm{Fe}$ & 70.1 & 70.1 & 70.0 & 70.6 & 70.2 & 70.0 & 67.4 & 67.3 & 70.3 \\
\hline${ }^{24} \mathrm{Mg}$ & 58.6 & 39 & 14 & 221 & 55.0 & 103 & 72.5 & 16.6 & 71.2 \\
\hline${ }^{27} \mathrm{Al}$ & 116 & 166 & 43 & 167 & 142 & 160 & 310 & 120 & $<\mathrm{LOD}$ \\
\hline${ }^{29} \mathrm{Si}$ & 2140 & 1130 & $<\mathrm{LOD}$ & 1055 & 1060 & 1373 & 1700 & 1845 & $<\mathrm{LOD}$ \\
\hline${ }^{31} \mathrm{P}$ & 36.5 & 196 & $<\mathrm{LOD}$ & 34.5 & 29.0 & 52.0 & 53.0 & 37.2 & $<\mathrm{LOD}$ \\
\hline${ }^{44} \mathrm{Ca}$ & 430 & 1050 & $<\mathrm{LOD}$ & $<\mathrm{LOD}$ & $<\mathrm{LOD}$ & 580 & 400 & $<\mathrm{LOD}$ & $<\mathrm{LOD}$ \\
\hline${ }^{47} \mathrm{Ti}$ & 123 & $<\mathrm{LOD}$ & $<\mathrm{LOD}$ & $<\mathrm{LOD}$ & 853 & 2164 & 12419 & 4648 & 1120 \\
\hline${ }^{51} \mathrm{~V}$ & 964 & 324 & 605 & 549 & 1075 & 940 & 1327 & 605 & 232 \\
\hline${ }^{52} \mathrm{Cr}$ & 93.0 & 431 & 47 & $<\mathrm{LOD}$ & 120 & 115 & 64.0 & 92.5 & 53.0 \\
\hline${ }^{55} \mathrm{Mn}$ & 428 & 94.6 & 240 & 388 & 149 & 62.5 & 56.6 & 16.5 & 38.9 \\
\hline${ }^{59} \mathrm{Co}$ & 43.1 & 10.0 & 76.9 & 121 & 130 & 127 & 6.33 & 2.86 & 70.9 \\
\hline${ }^{60} \mathrm{Ni}$ & $<\mathrm{LOD}$ & $<\mathrm{LOD}$ & 76 & 207 & 301 & 176 & 278 & $<\mathrm{LOD}$ & 78.6 \\
\hline${ }^{63} \mathrm{Cu}$ & $<\mathrm{LOD}$ & 13.9 & $<\mathrm{LOD}$ & $<\mathrm{LOD}$ & 9.40 & $<\mathrm{LOD}$ & 136 & 5.21 & $<\mathrm{LOD}$ \\
\hline${ }^{66} \mathrm{Zn}$ & 32.2 & 11.0 & 6.10 & 9.70 & 21.6 & 19.6 & 4.43 & $<\mathrm{LOD}$ & 5.29 \\
\hline${ }^{71} \mathrm{Ga}$ & 4.36 & 10.7 & 14 & 28 & 22.7 & 5.91 & 19.6 & 3.59 & 1.74 \\
\hline${ }^{88} \mathrm{Sr}$ & 0.68 & $<\mathrm{LOD}$ & $<\mathrm{LOD}$ & 1.23 & 0.87 & 3.99 & 2.68 & 1.07 & $<\mathrm{LOD}$ \\
\hline${ }^{89} \mathrm{Y}$ & 0.55 & 0.43 & $<\mathrm{LOD}$ & 0.17 & 1.04 & 0.63 & 0.89 & 1.37 & $<\mathrm{LOD}$ \\
\hline${ }^{93} \mathrm{Nb}$ & 0.32 & $<\mathrm{LOD}$ & $<\mathrm{LOD}$ & $<\mathrm{LOD}$ & 0.32 & 2.42 & 0.73 & 1.21 & 1.03 \\
\hline${ }^{118} \mathrm{Sn}$ & $<\mathrm{LOD}$ & $<\mathrm{LOD}$ & $<\mathrm{LOD}$ & $<\mathrm{LOD}$ & 1.43 & $<\mathrm{LOD}$ & 4.73 & 2.146 & $<\mathrm{LOD}$ \\
\hline${ }^{140} \mathrm{Ce}$ & 0.46 & 2.78 & 0.05 & 0.34 & 23.7 & 3.19 & 4.76 & 5.17 & 0.10 \\
\hline${ }^{178} \mathrm{Hf}$ & 6.70 & $<\mathrm{LOD}$ & 0.01 & 0.02 & $<\mathrm{LOD}$ & 0.01 & 0.06 & 0.91 & $<\mathrm{LOD}$ \\
\hline${ }^{181} \mathrm{Ta}$ & $<\mathrm{LOD}$ & $<\mathrm{LOD}$ & $<\mathrm{LOD}$ & $<\mathrm{LOD}$ & $<\mathrm{LOD}$ & 0.14 & 0.10 & 0.24 & $<\mathrm{LOD}$ \\
\hline${ }^{208} \mathrm{~Pb}$ & 0.57 & 0.27 & 0.62 & 0.21 & 0.61 & 2.32 & 1.09 & 2.66 & 0.26 \\
\hline${ }^{232} \mathrm{Th}$ & 0.93 & 0.07 & 0.06 & 0.09 & 1.33 & 0.31 & 0.78 & 0.70 & 0.02 \\
\hline
\end{tabular}


Appendix III. (continued)

\begin{tabular}{|c|c|c|c|c|c|c|c|c|c|}
\hline & $\begin{array}{c}\text { El Laco and } \\
\text { Láscar } \\
\text { Min LOD }\end{array}$ & $\begin{array}{c}\text { ELL-14-02 } \\
\quad \mathrm{N}=17\end{array}$ & $\begin{array}{c}\text { ELL-14-04 } \\
\mathrm{N}=14\end{array}$ & $\begin{array}{c}\text { ELL-14-05 } \\
\mathrm{N}=18\end{array}$ & $\begin{array}{c}\text { ELL-14-06 } \\
\quad \mathrm{N}=20\end{array}$ & $\begin{array}{c}\text { LAS-14-07 } \\
\qquad \begin{array}{c}\mathrm{N}=9 \\
\end{array}\end{array}$ & $\begin{array}{c}\text { LAS-14-07 } \\
\qquad \begin{array}{c}\mathrm{N}=9 \\
\end{array}\end{array}$ & $\begin{array}{c}\text { Balmat } \\
\mathrm{N}=18 \\
\end{array}$ & $\begin{array}{c}\text { BC-28 } \\
\mathrm{N}=14\end{array}$ \\
\hline $\mathrm{Fe}$ & EPMA & 63.6 & 69.4 & 68.9 & 68.1 & 68 & 60.4 & 68.7 & 57.2 \\
\hline${ }^{24} \mathrm{Mg}$ & 13.6 & 2560 & 6615 & 9626 & 5157 & 3606 & 14440 & 129 & 8175 \\
\hline${ }^{27} \mathrm{Al}$ & 39.1 & 6335 & 1642 & 1437 & 109 & 117 & 12599 & 91.0 & 12294 \\
\hline${ }^{29} \mathrm{Si}$ & 1349 & 4363 & 4178 & 7161 & 4890 & 2784 & 9500 & 1240 & 2700 \\
\hline${ }^{31} \mathrm{P}$ & 36.5 & 741 & 158 & 200 & 417 & 482 & 1188 & 26.4 & 188 \\
\hline${ }^{44} \mathrm{Ca}$ & 749 & $<\mathrm{LOD}$ & $<\mathrm{LOD}$ & 2510 & 1817 & 1130 & 4407 & $<\mathrm{LOD}$ & $<\mathrm{LOD}$ \\
\hline${ }^{47} \mathrm{Ti}$ & 59.6 & 65920 & 288 & 275 & 517 & 459 & 83000 & 66 & 70656 \\
\hline${ }^{51} \mathrm{~V}$ & 5.82 & 2947 & 1882 & 996 & 586 & 604 & 4574 & 408 & 10111 \\
\hline${ }^{52} \mathrm{Cr}$ & 21.2 & 710 & 100 & 54.5 & 72.4 & 35 & 822 & 134 & 1409 \\
\hline${ }^{55} \mathrm{Mn}$ & 4.75 & 4125 & 276 & 402 & 271 & 221 & 4093 & 346 & 2370 \\
\hline${ }^{59} \mathrm{Co}$ & 1.32 & 119 & 119.11 & 151 & 111 & 107 & 248 & 18.7 & 223 \\
\hline${ }^{60} \mathrm{Ni}$ & 19.5 & 200 & 438 & 434 & 275 & 269 & 353 & n.d. & 450 \\
\hline${ }^{63} \mathrm{Cu}$ & 3.66 & 28.4 & $<\mathrm{LOD}$ & 22.4 & 36.0 & 52.5 & 52.5 & n.d. & 126 \\
\hline${ }^{66} \mathrm{Zn}$ & 9.76 & 1651 & 51.5 & 49.8 & 51.8 & 1254 & 1254 & 22101 & 337 \\
\hline${ }^{71} \mathrm{Ga}$ & 0.33 & 49.1 & 6.31 & 2.06 & 1.14 & 64.9 & 64.9 & 35.6 & 55.6 \\
\hline${ }^{72} \mathrm{Ge}$ & 9.74 & $<\mathrm{LOD}$ & $<\mathrm{LOD}$ & $<\mathrm{LOD}$ & $<\mathrm{LOD}$ & $<\mathrm{LOD}$ & $<\mathrm{LOD}$ & 440 & n.d. \\
\hline${ }^{88} \mathrm{Sr}$ & 0.32 & 1.83 & 1.59 & 1.83 & 3.01 & 0.32 & 0.32 & 0.66 & 2.66 \\
\hline${ }^{89} \mathrm{Y}$ & 0.00 & 1.61 & 1.11 & 0.97 & 5.04 & 0.00 & 0.00 & n.d. & n.d. \\
\hline${ }^{93} \mathrm{Nb}$ & $<\mathrm{LOD}$ & 19.2 & 1.54 & 2.32 & 12.1 & 0.00 & 0.00 & n.d. & 1.30 \\
\hline${ }^{95} \mathrm{Mo}$ & 1.87 & $<\mathrm{LOD}$ & 3.60 & 9.57 & $<\mathrm{LOD}$ & 1.87 & 1.87 & 322 & $<\mathrm{LOD}$ \\
\hline${ }^{118} \mathrm{Sn}$ & 2.50 & 8.37 & 14.5 & 12.8 & 13.6 & 27.4 & 27.4 & 52.4 & 1.82 \\
\hline${ }^{140} \mathrm{Ce}$ & $<\mathrm{LOD}$ & 6.64 & 1.66 & 7.81 & 36.1 & 17.9 & 17.9 & 0.07 & 0.19 \\
\hline${ }^{181} \mathrm{Ta}$ & $<\mathrm{LOD}$ & 0.58 & 0.51 & 0.30 & 0.25 & 1.51 & 1.51 & n.d. & 0.08 \\
\hline
\end{tabular}

Note: $\mathrm{N}=$ total number of analysis; $<\mathrm{LOD}=$ below level of detection; n.d., =not determined 
Appendix IV. EPMA Fe results. Spot locations are shown on BSE images of magnetite grains in Appendix VI.

\begin{tabular}{|c|c|c|c|c|c|}
\hline $\begin{array}{l}\text { Analysis } \\
\text { I.D. }\end{array}$ & Sample I.D. & $\begin{array}{l}\text { Ablation } \\
\text { Analysis }\end{array}$ & $\mathrm{FeO}$ wt. $\%$ & Fe wt. $\%$ & $\begin{array}{l}\text { Avg. Spot } \\
\text { Analysis }\end{array}$ \\
\hline $\mathrm{a}$ & KRN-10-02 & ap22a08 & 89.9 & 69.9 & 69.8 \\
\hline $\mathrm{b}$ & KRN-10-02 & ap22a08 & 89.9 & 69.9 & \\
\hline $\mathrm{c}$ & KRN-10-02 & ap22a08 & 89.5 & 69.6 & \\
\hline e & KRN-10-02 & ap22a09 & 89.9 & 69.9 & 69.8 \\
\hline $\mathrm{f}$ & KRN-10-02 & ap22a09 & 90.0 & 69.9 & \\
\hline g & KRN-10-02 & ap22a09 & 89.5 & 69.6 & \\
\hline $\mathrm{h}$ & KRN-10-02 & ap22a 10 & 89.9 & 69.9 & 69.7 \\
\hline $\mathrm{i}$ & KRN-10-02 & ap22a 10 & 89.4 & 69.5 & \\
\hline $\mathrm{j}$ & KRN-10-02 & ap22a 10 & 89.7 & 69.8 & \\
\hline $\mathrm{J}$ & KRN-10-02 & ap22a11 & 89.5 & 69.6 & 69.7 \\
\hline 1 & KRN-10-02 & ap22a11 & 89.6 & 69.7 & \\
\hline $\mathrm{n}$ & KRN-10-02 & ap22a11 & 89.8 & 69.8 & \\
\hline o & KRN-10-02 & ap $22 \mathrm{a} 12$ & 89.7 & 69.7 & 69.1 \\
\hline $\mathrm{p}$ & KRN-10-02 & ap22a 12 & 88.0 & 68.4 & \\
\hline$q$ & KRN-10-02 & ap22a13 & 89.7 & 69.7 & 69.6 \\
\hline $\mathrm{r}$ & KRN-10-02 & ap22a13 & 89.5 & 69.6 & \\
\hline $\mathrm{s}$ & KRN-10-02 & ap $22 \mathrm{a} 13$ & 89.5 & 69.6 & \\
\hline $\mathrm{a}$ & $\mathrm{K}-1$ & ap22a 14 & 89.7 & 69.7 & 69.7 \\
\hline $\mathrm{b}$ & $\mathrm{K}-1$ & & 89.9 & 69.9 & \\
\hline $\mathrm{c}$ & K-1 & ap22a16 & 89.7 & 69.7 & 69.7 \\
\hline $\mathrm{d}$ & $\mathrm{K}-1$ & ap22a 17 & 89.6 & 69.6 & 69.6 \\
\hline $\mathrm{e}$ & $\mathrm{K}-1$ & ap22a 17 & 89.3 & 69.4 & \\
\hline $\mathrm{f}$ & K-1 & ap22a 17 & 89.6 & 69.6 & \\
\hline g & $\mathrm{K}-1$ & ap $22 \mathrm{a} 25$ & 89.3 & 69.4 & 69.4 \\
\hline $\mathrm{h}$ & $\mathrm{K}-1$ & ap $22 \mathrm{a} 25$ & 89.1 & 69.2 & \\
\hline $\mathrm{i}$ & $\mathrm{K}-1$ & ap22a25 & 89.4 & 69.5 & \\
\hline $\mathrm{j}$ & $\mathrm{K}-1$ & ap22a26 & 89.5 & 69.6 & 69.7 \\
\hline $\mathrm{k}$ & $\mathrm{K}-1$ & ap $22 \mathrm{a} 26$ & 89.7 & 69.7 & \\
\hline 1 & $\mathrm{~K}-1$ & ap $22 \mathrm{a} 26$ & 89.7 & 69.7 & \\
\hline $\mathrm{m}$ & K-1 & ap $22 \mathrm{a} 27$ & 89.6 & 69.6 & 69.6 \\
\hline $\mathrm{n}$ & $\mathrm{K}-1$ & ap22a 27 & 89.7 & 69.7 & \\
\hline o & K-1 & ap22a 27 & 89.3 & 69.4 & \\
\hline $\mathrm{p}$ & K-1 & ap $22 \mathrm{a} 28$ & 89.9 & 69.8 & 69.7 \\
\hline$q$ & $\mathrm{~K}-1$ & ap22a28 & 89.7 & 69.7 & \\
\hline $\mathrm{r}$ & $\mathrm{K}-1$ & ap22a 28 & 89.4 & 69.5 & \\
\hline $\mathrm{a}$ & K-2 & ap22a30 & 89.8 & 69.8 & 69.8 \\
\hline $\begin{array}{l}a \\
b\end{array}$ & $\mathrm{~K}-2$ & ap22a30 & 89.9 & 69.9 & \\
\hline $\mathrm{c}$ & $\mathrm{K}-2$ & ap22a30 & 89.8 & 69.8 & \\
\hline $\mathrm{d}$ & $\mathrm{K}-2$ & ap22a29 & 89.9 & 69.9 & 69.8 \\
\hline e & $\mathrm{K}-2$ & ap22a29 & 89.7 & 69.7 & \\
\hline $\mathrm{f}$ & $\mathrm{K}-2$ & ap22a29 & 89.8 & 69.8 & \\
\hline
\end{tabular}


Appendix IV. (Cont.)

\begin{tabular}{|c|c|c|c|c|c|}
\hline $\begin{array}{c}\text { Analysis } \\
\text { I.D. }\end{array}$ & Sample I.D. & $\begin{array}{l}\text { Ablation } \\
\text { Analysis }\end{array}$ & FeO wt. \% & Fe wt. $\%$ & $\begin{array}{c}\text { Avg. Spot } \\
\text { Analysis }\end{array}$ \\
\hline $\mathrm{g}$ & $\mathrm{K}-2$ & ap22a31 & 90.1 & 70.0 & 70.3 \\
\hline $\mathrm{h}$ & $\mathrm{K}-2$ & ap22a31 & 90.5 & 70.3 & \\
\hline $\mathrm{i}$ & $\mathrm{K}-2$ & ap22a31 & 90.7 & 70.5 & \\
\hline $\mathrm{j}$ & $\mathrm{K}-2$ & ap22a32 & 90.3 & 70.2 & 70.1 \\
\hline $\mathrm{k}$ & $\mathrm{K}-2$ & ap22a32 & 90.2 & 70.1 & \\
\hline 1 & $\mathrm{~K}-2$ & ap22a32 & 89.9 & 69.8 & \\
\hline $\mathrm{m}$ & $\mathrm{K}-2$ & ap22a33 & 90.5 & 70.4 & 70.3 \\
\hline $\mathrm{n}$ & $\mathrm{K}-2$ & ap22a33 & 90.3 & 70.2 & \\
\hline $\mathrm{o}$ & $\mathrm{K}-2$ & ap22a33 & 90.4 & 70.2 & \\
\hline $\mathrm{p}$ & K-2 & ap22a34 & 90.4 & 70.2 & 70.3 \\
\hline $\mathrm{q}$ & $\mathrm{K}-2$ & ap22a34 & 90.5 & 70.3 & \\
\hline $\mathrm{r}$ & $\mathrm{K}-2$ & ap22a34 & 90.6 & 70.4 & \\
\hline $\mathrm{s}$ & $\mathrm{K}-2$ & ap22a42 & 89.8 & 69.8 & 69.7 \\
\hline $\mathrm{t}$ & $\mathrm{K}-2$ & ap22a42 & 89.8 & 69.8 & \\
\hline $\mathrm{u}$ & $\mathrm{K}-2$ & ap $22 \mathrm{a} 42$ & 89.6 & 69.6 & \\
\hline $\mathrm{v}$ & $\mathrm{K}-2$ & ap22a43 & 90.0 & 70.0 & 69.4 \\
\hline $\mathrm{w}$ & $\mathrm{K}-2$ & ap22a43 & 89.8 & 69.8 & \\
\hline $\mathrm{x}$ & $\mathrm{K}-2$ & ap $22 \mathrm{a} 43$ & 87.9 & 68.4 & \\
\hline $\mathrm{y}$ & $\mathrm{K}-2$ & ap22a44 & 89.6 & 69.7 & 69.9 \\
\hline $\mathrm{Z}$ & $\mathrm{K}-2$ & ap22a44 & 89.8 & 69.8 & \\
\hline $\mathrm{ZZ}$ & $\mathrm{K}-2$ & ap22a44 & 90.2 & 70.1 & \\
\hline $\mathrm{a}$ & KRN-11-01 & ap22a46 & 86.8 & 67.4 & 69.3 \\
\hline $\mathrm{b}$ & KRN-11-01 & ap22a46 & 90.4 & 70.3 & \\
\hline $\mathrm{c}$ & KRN-11-01 & ap22a46 & 90.4 & 70.3 & \\
\hline d & KRN-11-01 & ap $22 \mathrm{a} 47$ & 90.0 & 70.0 & 70.1 \\
\hline e & KRN-11-01 & ap22a47 & 90.3 & 70.2 & \\
\hline $\mathrm{f}$ & KRN-11-01 & ap22a47 & 90.2 & 70.1 & \\
\hline $\mathrm{g}$ & KRN-11-01 & ap22a48 & 90.4 & 70.2 & 70.2 \\
\hline h & KRN-11-01 & ap22a48 & 90.2 & 70.1 & \\
\hline $\mathrm{i}$ & KRN-11-01 & ap22a48 & 90.2 & 70.1 & \\
\hline $\mathrm{j}$ & KRN-11-01 & ap22a49 & 90.2 & 70.1 & 70.1 \\
\hline $\mathrm{k}$ & KRN-11-01 & ap22a50 & 90.2 & 70.1 & 70.1 \\
\hline 1 & KRN-11-01 & ap22a51 & 90.6 & 70.4 & 70.4 \\
\hline $\mathrm{m}$ & KRN-11-01 & & 89.5 & 69.6 & \\
\hline $\mathrm{n}$ & KRN-11-01 & ap22a60 & 90.2 & 70.1 & 70.1 \\
\hline o & KRN-11-01 & & 90.8 & 70.6 & \\
\hline $\mathrm{a}$ & KRN-11-03 & ap22a80 & 90.5 & 70.4 & 70.2 \\
\hline $\mathrm{b}$ & KRN-11-03 & ap22a80 & 90.4 & 70.2 & \\
\hline $\mathrm{c}$ & KRN-11-03 & ap22a80 & 90.2 & 70.1 & \\
\hline d & KRN-11-03 & ap22a81/82 & 90.2 & 70.1 & 70.4 \\
\hline $\mathrm{e}$ & KRN-11-03 & ap22a81/82 & 90.7 & 70.5 & \\
\hline
\end{tabular}


Appendix IV. (Cont.)

\begin{tabular}{|c|c|c|c|c|c|}
\hline $\begin{array}{c}\text { Analysis } \\
\text { I.D. }\end{array}$ & Sample I.D. & $\begin{array}{l}\text { Ablation } \\
\text { Analysis }\end{array}$ & FeO wt. \% & Fe wt. $\%$ & $\begin{array}{c}\text { Avg. Spot } \\
\text { Analysis }\end{array}$ \\
\hline $\mathrm{f}$ & KRN-11-03 & ap22a81/82 & 90.7 & 70.5 & \\
\hline g & KRN-11-03 & & 89.6 & 69.6 & \\
\hline $\mathrm{h}$ & KRN-11-03 & & 90.0 & 70.0 & \\
\hline $\mathrm{i}$ & KRN-11-03 & & 90.1 & 70.1 & \\
\hline $\mathrm{j}$ & KRN-11-03 & ap22a83/84 & 90.5 & 70.3 & 70.2 \\
\hline $\mathrm{k}$ & KRN-11-03 & ap22a83/84 & 90.4 & 70.3 & \\
\hline 1 & KRN-11-03 & ap22a83/84 & 90.1 & 70.1 & \\
\hline $\mathrm{a}$ & KRN-11-04 & ap22a85 & 90.4 & 70.3 & 70.3 \\
\hline $\mathrm{b}$ & KRN-11-04 & ap22a85 & 90.3 & 70.2 & \\
\hline $\mathrm{c}$ & KRN-11-04 & & 91.0 & 70.7 & \\
\hline $\mathrm{d}$ & KRN-11-04 & ap22a86 & 90.7 & 70.5 & 70.5 \\
\hline $\mathrm{e}$ & KRN-11-04 & ap22a86 & 90.8 & 70.6 & \\
\hline $\mathrm{f}$ & KRN-11-04 & ap22a86 & 90.7 & 70.5 & \\
\hline g & KRN-11-04 & ap22a87 & 90.8 & 70.6 & 70.6 \\
\hline $\mathrm{h}$ & KRN-11-04 & ap22a87 & 90.8 & 70.6 & \\
\hline $\mathrm{i}$ & KRN-11-04 & ap22a87 & 90.8 & 70.6 & \\
\hline $\mathrm{j}$ & KRN-11-04 & ap23a05 & 90.4 & 70.3 & 70.1 \\
\hline $\mathrm{k}$ & KRN-11-04 & ap23a05 & 90.3 & 70.2 & \\
\hline 1 & KRN-11-04 & ap23a05 & 89.9 & 69.9 & \\
\hline $\mathrm{m}$ & KRN-11-04 & ap23a06 & 90.4 & 70.3 & 70.2 \\
\hline $\mathrm{n}$ & KRN-11-04 & ap23a06 & 90.2 & 70.1 & \\
\hline $\mathrm{o}$ & KRN-11-04 & ap23a07 & 90.6 & 70.4 & 70.1 \\
\hline $\mathrm{p}$ & KRN-11-04 & ap23a07 & 90.1 & 70.1 & \\
\hline $\mathrm{q}$ & KRN-11-04 & ap23a07 & 89.9 & 69.9 & \\
\hline $\mathrm{r}$ & KRN-11-04 & ap23a08 & 90.0 & 70.0 & 70.1 \\
\hline $\mathrm{s}$ & KRN-11-04 & ap23a08 & 90.4 & 70.2 & \\
\hline $\mathrm{t}$ & KRN-11-04 & ap23a08 & 90.0 & 70.0 & \\
\hline $\mathrm{a}$ & KRN-11-05 & ap23a10 & 89.4 & 69.5 & 69.6 \\
\hline $\mathrm{b}$ & KRN-11-05 & ap23a10 & 89.6 & 69.6 & \\
\hline $\mathrm{c}$ & KRN-11-05 & ap23a10 & 89.7 & 69.7 & \\
\hline $\mathrm{d}$ & KRN-11-05 & & 89.8 & 69.8 & \\
\hline $\mathrm{e}$ & KRN-11-05 & & 88.9 & 69.1 & \\
\hline $\mathrm{f}$ & KRN-11-05 & & 89.7 & 69.7 & \\
\hline $\mathrm{g}$ & KRN-11-05 & ap23a09 & 90.4 & 70.3 & 70.1 \\
\hline $\mathrm{h}$ & KRN-11-05 & ap23a09 & 90.1 & 70.1 & \\
\hline $\mathrm{i}$ & KRN-11-05 & ap23a09 & 90.1 & 70.1 & 69.8 \\
\hline $\mathrm{a}$ & KRN-12-02 & ap23a12 & 90.0 & 70.0 & \\
\hline $\mathrm{b}$ & KRN-12-02 & ap23a12 & 90.1 & 70.0 & \\
\hline $\mathrm{c}$ & KRN-12-02 & ap23a12 & 89.5 & 69.6 & 70.0 \\
\hline d & KRN-12-02 & ap23a11 & 90.3 & 70.2 & \\
\hline $\mathrm{e}$ & KRN-12-02 & ap23a11 & 89.9 & 69.9 & \\
\hline
\end{tabular}


Appendix IV. (Cont.)

\begin{tabular}{|c|c|c|c|c|c|}
\hline $\begin{array}{c}\text { Analysis } \\
\text { I.D. }\end{array}$ & Sample I.D. & $\begin{array}{l}\text { Ablation } \\
\text { Analysis }\end{array}$ & FeO wt. $\%$ & Fe wt. $\%$ & $\begin{array}{c}\text { Avg. Spot } \\
\text { Analysis }\end{array}$ \\
\hline $\mathrm{f}$ & KRN-12-02 & ap23a11 & 89.9 & 69.9 & 69.8 \\
\hline g & KRN-12-02 & ap23a13 & 89.9 & 69.9 & \\
\hline $\mathrm{h}$ & KRN-12-02 & ap23a13 & 90.0 & 70.0 & \\
\hline $\mathrm{i}$ & KRN-12-02 & ap23a13 & 89.6 & 69.7 & 70.0 \\
\hline $\mathrm{a}$ & KRN-12-03 & ap23a25 & 90.0 & 70.0 & \\
\hline $\mathrm{b}$ & KRN-12-03 & & 90.4 & 70.3 & 70.0 \\
\hline $\mathrm{c}$ & KRN-12-03 & ap23a26 & 90.1 & 70.0 & 70.1 \\
\hline d & KRN-12-03 & ap23a14 & 90.3 & 70.2 & \\
\hline $\mathrm{e}$ & KRN-12-03 & ap23a14 & 90.0 & 70.0 & \\
\hline $\mathrm{f}$ & KRN-12-03 & ap23a14 & 90.2 & 70.1 & 70.2 \\
\hline g & KRN-12-03 & ap23a27 & 90.4 & 70.3 & \\
\hline $\mathrm{h}$ & KRN-12-03 & ap23a27 & 90.5 & 70.4 & \\
\hline $\mathrm{i}$ & KRN-12-03 & ap23a27 & 90.1 & 70.0 & 70.1 \\
\hline $\mathrm{j}$ & KRN-12-03 & ap23a28 & 90.2 & 70.1 & \\
\hline $\mathrm{k}$ & KRN-12-03 & ap23a28 & 90.3 & 70.2 & \\
\hline 1 & KRN-12-03 & ap23a28 & 90.2 & 70.1 & 70.4 \\
\hline $\mathrm{m}$ & KRN-12-03 & ap23a29 & 90.9 & 70.7 & \\
\hline $\mathrm{n}$ & KRN-12-03 & ap23a29 & 90.7 & 70.5 & \\
\hline o & KRN-12-03 & ap23a29 & 90.2 & 70.1 & 70.3 \\
\hline $\mathrm{p}$ & KRN-12-03 & ap23a30 & 90.4 & 70.3 & \\
\hline$q$ & KRN-12-03 & ap23a30 & 90.6 & 70.4 & \\
\hline $\mathrm{r}$ & KRN-12-03 & ap23a30 & 90.1 & 70.0 & 70.0 \\
\hline $\mathrm{a}$ & KRN-12-05 & ap23a31 & 90.3 & 70.2 & \\
\hline $\mathrm{b}$ & KRN-12-05 & ap23a31 & 89.9 & 69.9 & \\
\hline $\mathrm{c}$ & KRN-12-05 & ap23a31 & 90.0 & 69.9 & 70.1 \\
\hline e & KRN-12-05 & ap23a40 & 90.2 & 70.1 & \\
\hline $\mathrm{f}$ & KRN-12-05 & ap23a40 & 90.0 & 69.9 & \\
\hline $\mathrm{g}$ & KRN-12-05 & ap23a40 & 90.5 & 70.3 & \\
\hline $\mathrm{h}$ & KRN-12-05 & & 90.2 & 70.1 & \\
\hline $\mathrm{i}$ & KRN-12-05 & & 90.0 & 69.9 & \\
\hline $\mathrm{j}$ & KRN-12-05 & & 90.3 & 70.2 & \\
\hline $\mathrm{a}$ & TUV-10-03 & & 90.4 & 70.3 & \\
\hline $\mathrm{b}$ & TUV-10-03 & & 90.0 & 69.9 & \\
\hline $\mathrm{c}$ & TUV-10-03 & & 90.2 & 70.1 & \\
\hline $\mathrm{d}$ & TUV-10-03 & ap23a61 & 90.2 & 70.1 & 70.0 \\
\hline e & TUV-10-03 & ap23a61 & 89.7 & 69.8 & \\
\hline $\mathrm{f}$ & TUV-10-03 & ap23a61 & 90.3 & 70.2 & \\
\hline $\mathrm{g}$ & TUV-10-03 & & 90.4 & 70.3 & \\
\hline $\mathrm{h}$ & TUV-10-03 & & 90.0 & 70.0 & \\
\hline $\mathrm{i}$ & TUV-10-03 & & 88.3 & 68.6 & \\
\hline $\mathrm{j}$ & TUV-10-03 & ap23a63 & 89.8 & 69.8 & 69.4 \\
\hline
\end{tabular}


Appendix IV. (Cont.)

\begin{tabular}{|c|c|c|c|c|c|}
\hline $\begin{array}{l}\text { Analysis } \\
\text { I.D. }\end{array}$ & Sample I.D. & $\begin{array}{l}\text { Ablation } \\
\text { Analysis }\end{array}$ & FeO wt. \% & Fe wt. $\%$ & $\begin{array}{c}\text { Avg. Spot } \\
\text { Analysis }\end{array}$ \\
\hline $\mathrm{k}$ & TUV-10-03 & ap23a63 & 90.3 & 70.2 & \\
\hline 1 & TUV-10-03 & ap23a63 & 89.8 & 69.8 & \\
\hline $\mathrm{m}$ & TUV-10-03 & ap23a63 & 87.1 & 67.7 & \\
\hline $\mathrm{a}$ & TUV-10-01 & ap22a67 & 90.5 & 70.4 & 70.3 \\
\hline $\mathrm{b}$ & TUV-10-01 & ap22a67 & 90.3 & 70.2 & \\
\hline $\mathrm{c}$ & TUV-10-01 & ap22a67 & 90.7 & 70.5 & \\
\hline d & TUV-10-01 & ap22a68 & 90.7 & 70.5 & 70.5 \\
\hline $\mathrm{e}$ & TUV-10-01 & ap22a68 & 90.6 & 70.4 & \\
\hline $\mathrm{f}$ & TUV-10-01 & ap22a68 & 90.8 & 70.6 & \\
\hline $\mathrm{g}$ & TUV-10-01 & ap22a69 & 91.2 & 70.9 & 70.5 \\
\hline $\mathrm{h}$ & TUV-10-01 & ap22a69 & 90.5 & 70.4 & \\
\hline $\mathrm{i}$ & TUV-10-01 & ap22a69 & 90.6 & 70.4 & \\
\hline $\mathrm{j}$ & TUV-10-01 & ap22a77 & 90.9 & 70.7 & 70.7 \\
\hline $\mathrm{k}$ & TUV-10-01 & ap22a77 & 91.0 & 70.8 & \\
\hline 1 & TUV-10-01 & ap22a77 & 91.1 & 70.8 & \\
\hline $\mathrm{m}$ & TUV-10-01 & & 91.0 & 70.7 & \\
\hline $\mathrm{n}$ & TUV-10-01 & & 90.5 & 70.4 & \\
\hline o & TUV-10-01 & & 90.8 & 70.6 & \\
\hline $\mathrm{a}$ & NUK-10-03 & ap23a41 & 90.0 & 70.0 & 70.0 \\
\hline $\mathrm{b}$ & NUK-10-03 & ap23a41 & 89.6 & 69.7 & \\
\hline $\mathrm{c}$ & NUK-10-03 & ap23a41 & 90.5 & 70.3 & \\
\hline $\mathrm{d}$ & NUK-10-03 & ap23a42 & 90.6 & 70.4 & 70.6 \\
\hline $\mathrm{e}$ & NUK-10-03 & ap23a42 & 90.8 & 70.6 & \\
\hline $\mathrm{f}$ & NUK-10-03 & ap23a42 & 90.8 & 70.6 & \\
\hline g & NUK-10-03 & ap23a43 & 90.1 & 70.0 & 70.1 \\
\hline $\mathrm{h}$ & NUK-10-03 & ap23a43 & 90.3 & 70.2 & \\
\hline $\mathrm{i}$ & NUK-10-03 & ap23a43 & 90.1 & 70.0 & \\
\hline $\mathrm{j}$ & NUK-10-03 & ap23a44 & 89.1 & 69.3 & 69.9 \\
\hline $\mathrm{k}$ & NUK-10-03 & ap23a44 & 90.3 & 70.2 & \\
\hline 1 & NUK-10-03 & ap23a44 & 90.5 & 70.3 & \\
\hline $\mathrm{m}$ & NUK-10-03 & ap23a45 & 90.3 & 70.2 & 70.2 \\
\hline $\mathrm{n}$ & NUK-10-03 & & 90.5 & 70.4 & \\
\hline o & NUK-10-03 & ap23a46 & 90.1 & 70.1 & 70.1 \\
\hline $\mathrm{a}$ & NUK-12-02 & ap23a47 & 90.0 & 70.0 & 69.9 \\
\hline $\mathrm{b}$ & NUK-12-02 & ap23a47 & 90.2 & 70.1 & \\
\hline $\mathrm{c}$ & NUK-12-02 & ap23a47 & 89.6 & 69.7 & \\
\hline d & NUK-12-02 & ap23a48 & 89.8 & 69.8 & 69.8 \\
\hline $\mathrm{e}$ & NUK-12-02 & ap23a48 & 89.7 & 69.7 & \\
\hline $\mathrm{f}$ & NUK-12-02 & ap23a48 & 89.9 & 69.9 & \\
\hline g & NUK-12-02 & ap23a49 & 90.3 & 70.2 & 69.9 \\
\hline $\mathrm{h}$ & NUK-12-02 & ap23a49 & 89.7 & 69.7 & \\
\hline
\end{tabular}




\begin{tabular}{|c|c|c|c|c|c|}
\hline $\begin{array}{c}\text { Analysis } \\
\text { I.D. }\end{array}$ & Sample I.D. & $\begin{array}{l}\text { Ablation } \\
\text { Analysis }\end{array}$ & FeO wt. \% & Fe wt. $\%$ & $\begin{array}{c}\text { Avg. Spot } \\
\text { Analysis }\end{array}$ \\
\hline $\mathrm{i}$ & NUK-12-02 & ap23a49 & 89.7 & 69.7 & \\
\hline $\mathrm{j}$ & NUK-12-02 & ap23a59 & 90.2 & 70.1 & 70.1 \\
\hline $\mathrm{k}$ & NUK-12-02 & & 90.1 & 70.0 & \\
\hline 1 & NUK-12-02 & ap23a58 & 90.3 & 70.2 & 70.2 \\
\hline $\mathrm{m}$ & NUK-12-02 & ap23a60 & 90.2 & 70.1 & 70.2 \\
\hline $\mathrm{n}$ & NUK-12-02 & ap23a60 & 90.1 & 70.0 & \\
\hline o & NUK-12-02 & ap23a60 & 90.5 & 70.3 & \\
\hline $\mathrm{a}$ & REK-10-01 & ap23a64 & 86.8 & 67.5 & 67.4 \\
\hline $\mathrm{b}$ & REK-10-01 & ap23a64 & 86.7 & 67.4 & \\
\hline $\mathrm{c}$ & REK-10-01 & ap23a64 & 86.7 & 67.4 & \\
\hline $\mathrm{d}$ & REK-10-01 & ap23a65 & 86.7 & 67.4 & 67.5 \\
\hline $\mathrm{e}$ & REK-10-01 & ap23a65 & 87.1 & 67.7 & \\
\hline $\mathrm{f}$ & REK-10-01 & ap23a65 & 86.6 & 67.3 & \\
\hline g & REK-10-01 & ap23a66 & 86.3 & 67.1 & 67.0 \\
\hline $\mathrm{h}$ & REK-10-01 & ap23a66 & 86.2 & 67.0 & \\
\hline $\mathrm{i}$ & REK-10-01 & ap23a66 & 85.9 & 66.8 & \\
\hline $\mathrm{j}$ & REK-10-01 & ap23a67 & 86.6 & 67.3 & 67.2 \\
\hline $\mathrm{k}$ & REK-10-01 & ap23a67 & 86.6 & 67.3 & \\
\hline 1 & REK-10-01 & ap23a67 & 86.4 & 67.1 & \\
\hline $\mathrm{m}$ & REK-10-01 & ap23a68 & 86.4 & 67.2 & 67.3 \\
\hline $\mathrm{n}$ & REK-10-01 & ap23a68 & 86.8 & 67.5 & \\
\hline $\mathrm{o}$ & REK-10-01 & ap23a68 & 86.7 & 67.4 & \\
\hline $\mathrm{a}$ & REK-10-04 & ap22a61 & 84.3 & 65.5 & 64.6 \\
\hline $\mathrm{b}$ & REK-10-04 & ap22a61 & 82.1 & 63.8 & \\
\hline $\mathrm{c}$ & REK-10-04 & ap22a62 & 82.1 & 63.9 & 64.8 \\
\hline $\mathrm{d}$ & REK-10-04 & ap22a62 & 84.6 & 65.7 & \\
\hline $\mathrm{e}$ & REK-10-04 & ap22a63 & 89.5 & 69.6 & 68.5 \\
\hline $\mathrm{f}$ & REK-10-04 & ap22a63 & 85.0 & 66.1 & \\
\hline $\mathrm{g}$ & REK-10-04 & ap22a63 & 89.9 & 69.9 & \\
\hline $\mathrm{h}$ & REK-10-04 & ap22a64 & 90.3 & 70.2 & 70.3 \\
\hline $\mathrm{i}$ & REK-10-04 & ap22a64 & 90.5 & 70.4 & \\
\hline $\mathrm{j}$ & REK-10-04 & ap22a64 & 90.6 & 70.4 & \\
\hline $\mathrm{k}$ & REK-10-04 & ap22a66 & 90.6 & 70.4 & 70.4 \\
\hline 1 & REK-10-04 & ap22a65 & 91.2 & 70.9 & 68.6 \\
\hline $\mathrm{m}$ & REK-10-04 & ap22a65 & 85.3 & 66.3 & \\
\hline $\mathrm{n}$ & REK-10-04 & ap22a66 & 90.0 & 70.0 & 70.0 \\
\hline $\mathrm{o}$ & REK-10-04 & ap22a65 & 84.7 & 65.9 & \\
\hline $\mathrm{a}$ & REK-12-02 & ap23a76 & 90.7 & 70.5 & 70.5 \\
\hline $\mathrm{b}$ & REK-12-02 & ap23a76 & 90.7 & 70.5 & \\
\hline $\mathrm{c}$ & REK-12-02 & ap23a76 & 90.7 & 70.5 & \\
\hline $\mathrm{d}$ & REK-12-02 & ap23a77 & 90.0 & 70.0 & 70.0 \\
\hline
\end{tabular}


Appendix IV. (Cont.)

\begin{tabular}{cccccc}
$\begin{array}{c}\text { Analysis } \\
\text { I.D. }\end{array}$ & Sample I.D. & $\begin{array}{c}\text { Ablation } \\
\text { Analysis }\end{array}$ & FeO wt. \% & Fe wt. \% & $\begin{array}{c}\text { Avg. Spot } \\
\text { Analysis }\end{array}$ \\
\hline e & REK-12-02 & ap23a77 & 90.2 & 70.1 & \\
f & REK-12-02 & ap23a77 & 89.9 & 69.9 & 70.3 \\
g & REK-12-02 & ap23a78 & 90.4 & 70.2 & \\
h & REK-12-02 & ap23a78 & 90.6 & 70.4 & 70.2 \\
i & REK-12-02 & ap23a78 & 90.2 & 70.1 & \\
j & REK-12-02 & ap23a79 & 90.5 & 70.3 & 70.4 \\
k & REK-12-02 & ap23a79 & 90.1 & 70.1 & 70.6 \\
l & REK-12-02 & ap23a79 & 90.4 & 70.3 & \\
m & REK-12-02 & ap23a81 & 90.6 & 70.4 & \\
n & REK-12-02 & ap23a80 & 90.9 & 70.6 &
\end{tabular}


Appendix IV. (Cont.)

\begin{tabular}{|c|c|c|c|c|c|}
\hline $\begin{array}{c}\text { Analysis } \\
\text { I.D. }\end{array}$ & Sample I.D. & $\begin{array}{l}\text { Ablation } \\
\text { Analysis }\end{array}$ & FeO wt. \% & Fe wt. $\%$ & $\begin{array}{c}\text { Avg. Spot } \\
\text { Analysis }\end{array}$ \\
\hline 1 & ELL-14-02 & no05b09 & 83.4 & 64.9 & 62.6 \\
\hline 2 & ELL-14-02 & no05b09 & 75.4 & 58.6 & \\
\hline 3 & ELL-14-02 & no05b09 & 82.9 & 64.5 & \\
\hline 4 & ELL-14-02 & no05b10 & 79.1 & 61.5 & 61.5 \\
\hline 5 & ELL-14-02 & no05b10 & 80.7 & 62.7 & \\
\hline 6 & ELL-14-02 & no05b10 & 77.6 & 60.3 & \\
\hline 7 & ELL-14-02 & no05b11 & 81.3 & 63.2 & 62.8 \\
\hline 8 & ELL-14-02 & no05b11 & 80.2 & 62.4 & \\
\hline 9 & ELL-14-02 & no05b11 & 81.0 & 63.0 & \\
\hline 10 & ELL-14-02 & no05b12 & 85.0 & 66.0 & 65.6 \\
\hline 11 & ELL-14-02 & no05b12 & 85.4 & 66.4 & \\
\hline 12 & ELL-14-02 & no05b12 & 82.8 & 64.4 & \\
\hline 13 & ELL-14-02 & no05b15 & 85.0 & 66.1 & 65.3 \\
\hline 14 & ELL-14-02 & no05b15 & 84.6 & 65.8 & \\
\hline 15 & ELL-14-02 & no05b15 & 82.5 & 64.1 & \\
\hline 16 & ELL-14-02 & no05b16 & 81.0 & 63.0 & 63.4 \\
\hline 17 & ELL-14-02 & no05b16 & 83.8 & 65.1 & \\
\hline 18 & ELL-14-02 & no05b16 & 79.8 & 62.0 & \\
\hline 19 & ELL-14-02 & no05b17 & 82.2 & 63.9 & 64.1 \\
\hline 20 & ELL-14-02 & no05b17 & 79.7 & 61.9 & \\
\hline 21 & ELL-14-02 & no05b17 & 85.4 & 66.4 & \\
\hline 22 & ELL-14-02 & no05b18 & 83.0 & 64.5 & 63.9 \\
\hline 23 & ELL-14-02 & no05b18 & 82.1 & 63.8 & \\
\hline 24 & ELL-14-02 & no05b18 & 81.6 & 63.4 & \\
\hline 25 & ELL-14-02 & no05b21 & 80.6 & 62.6 & 64.2 \\
\hline 26 & ELL-14-02 & no05b21 & 80.4 & 62.5 & \\
\hline 27 & ELL-14-02 & no05b21 & 86.8 & 67.4 & \\
\hline 28 & ELL-14-02 & no05b22 & 67.8 & 52.7 & 59.4 \\
\hline 29 & ELL-14-02 & no05b22 & 80.7 & 62.7 & \\
\hline 30 & ELL-14-02 & no05b22 & 80.9 & 62.9 & \\
\hline 31 & ELL-14-02 & no05b23 & 78.4 & 60.9 & 62.4 \\
\hline 32 & ELL-14-02 & no05b23 & 81.6 & 63.4 & \\
\hline 33 & ELL-14-02 & no05b23 & 80.7 & 62.7 & \\
\hline 34 & ELL-14-02 & no05b24 & 81.5 & 63.3 & 64.2 \\
\hline 35 & ELL-14-02 & no05b24 & 85.5 & 66.5 & \\
\hline 36 & ELL-14-02 & no05b24 & 80.6 & 62.7 & \\
\hline 37 & ELL-14-02 & no05b26/27 & 81.2 & 63.1 & 62.5 \\
\hline 38 & ELL-14-02 & no05b26/27 & 79.5 & 61.8 & \\
\hline 1 & ELL-14-04 & no05d05 & 83.0 & 64.5 & 65.9 \\
\hline 2 & ELL-14-04 & no05d05 & 86.6 & 67.3 & \\
\hline 3 & ELL-14-04 & no05d06 & 87.0 & 67.6 & 66.9 \\
\hline 4 & ELL-14-04 & no05d06 & 85.3 & 66.3 & \\
\hline
\end{tabular}


Appendix IV. (Cont.)

\begin{tabular}{|c|c|c|c|c|c|}
\hline $\begin{array}{c}\text { Analysis } \\
\text { I.D. }\end{array}$ & Sample I.D. & $\begin{array}{l}\text { Ablation } \\
\text { Analysis }\end{array}$ & $\mathrm{FeO}$ wt. \% & Fe wt. $\%$ & $\begin{array}{c}\text { Avg. Spot } \\
\text { Analysis }\end{array}$ \\
\hline 5 & ELL-14-04 & no05d07 & 89.7 & 69.7 & 68.1 \\
\hline 6 & ELL-14-04 & no05d07 & 85.7 & 66.6 & \\
\hline 7 & ELL-14-04 & no05d07 & 87.4 & 67.9 & \\
\hline 8 & ELL-14-04 & no05d08 & 90.2 & 70.1 & 70.0 \\
\hline 9 & ELL-14-04 & no05d08 & 89.4 & 69.5 & \\
\hline 10 & ELL-14-04 & no05d08 & 90.5 & 70.3 & \\
\hline 11 & ELL-14-04 & no05d09 & 90.1 & 70.0 & 69.7 \\
\hline 12 & ELL-14-04 & no05d09 & 88.5 & 68.8 & \\
\hline 13 & ELL-14-04 & no05d09 & 90.6 & 70.4 & \\
\hline 14 & ELL-14-04 & no05d10 & 90.0 & 69.9 & 70.1 \\
\hline 15 & ELL-14-04 & no05d10 & 90.3 & 70.2 & \\
\hline 16 & ELL-14-04 & no05d11 & 90.9 & 70.6 & 70.0 \\
\hline 17 & ELL-14-04 & no05d11 & 90.2 & 70.1 & \\
\hline 18 & ELL-14-04 & no05d11 & 89.1 & 69.2 & \\
\hline 19 & ELL-14-04 & no05d12 & 90.2 & 70.1 & 70.1 \\
\hline 20 & ELL-14-04 & no05d12 & 90.0 & 69.9 & \\
\hline 21 & ELL-14-04 & no05d12 & 90.4 & 70.3 & \\
\hline 22 & ELL-14-04 & no05d13 & 90.6 & 70.4 & 70.1 \\
\hline 23 & ELL-14-04 & no05d13 & 89.7 & 69.8 & \\
\hline 24 & ELL-14-04 & no05d13 & 90.4 & 70.2 & \\
\hline 25 & ELL-14-04 & no05d14 & 90.2 & 70.1 & 70.2 \\
\hline 26 & ELL-14-04 & no05d14 & 90.5 & 70.3 & \\
\hline 27 & ELL-14-04 & no05d14 & 90.5 & 70.3 & \\
\hline 30 & ELL-14-04 & no05d17 & 90.5 & 70.3 & 69.9 \\
\hline 31 & ELL-14-04 & no05d17 & 89.9 & 69.9 & \\
\hline 32 & ELL-14-04 & no05d17 & 89.5 & 69.6 & \\
\hline 33 & ELL-14-04 & no05d18 & 90.0 & 69.9 & 69.2 \\
\hline 34 & ELL-14-04 & no05d18 & 89.2 & 69.3 & \\
\hline 35 & ELL-14-04 & no05d18 & 88.1 & 68.5 & \\
\hline 36 & ELL-14-04 & no05d19 & 90.2 & 70.1 & 69.9 \\
\hline 37 & ELL-14-04 & no05d19 & 90.4 & 70.2 & \\
\hline 38 & ELL-14-04 & no05d19 & 89.0 & 69.2 & \\
\hline 39 & ELL-14-04 & no05d 20 & 90.7 & 70.5 & 70.4 \\
\hline 40 & ELL-14-04 & no05d20 & 90.5 & 70.3 & \\
\hline 41 & ELL-14-04 & no05d20 & 90.4 & 70.3 & \\
\hline 1 & ELL-14-05 & no05c08 & 89.1 & 69.2 & 69.6 \\
\hline 2 & ELL-14-05 & no05c08 & 89.4 & 69.5 & \\
\hline 3 & ELL-14-05 & no05c08 & 90.1 & 70.0 & \\
\hline 4 & ELL-14-05 & no05c09 & 87.4 & 68.0 & 68.4 \\
\hline 5 & ELL-14-05 & no05c09 & 88.1 & 68.5 & \\
\hline 6 & ELL-14-05 & no05c09 & 88.4 & 68.7 & \\
\hline 7 & ELL-14-05 & no05c10 & 85.7 & 66.6 & 69.1 \\
\hline 8 & ELL-14-05 & no05c10 & 90.4 & 70.2 & \\
\hline 9 & ELL-14-05 & no05c10 & 90.7 & 70.5 & \\
\hline
\end{tabular}


Appendix IV. (Cont.)

\begin{tabular}{|c|c|c|c|c|c|}
\hline $\begin{array}{c}\text { Analysis } \\
\text { I.D. }\end{array}$ & Sample I.D. & $\begin{array}{l}\text { Ablation } \\
\text { Analysis }\end{array}$ & FeO wt. $\%$ & Fe wt. $\%$ & $\begin{array}{c}\text { Avg. Spot } \\
\text { Analysis }\end{array}$ \\
\hline 1 & ELL-14-06 & no05a06 & 85.9 & 66.8 & 67.4 \\
\hline 2 & ELL-14-06 & no05a06 & 86.4 & 67.1 & \\
\hline 3 & ELL-14-06 & no05a07 & 86.0 & 66.8 & 67.2 \\
\hline 4 & ELL-14-06 & no05a07 & 87.0 & 67.7 & \\
\hline 5 & ELL-14-06 & no05a07 & 86.5 & 67.3 & \\
\hline 6 & ELL-14-06 & no05a08 & 87.9 & 68.3 & 68.0 \\
\hline 7 & ELL-14-06 & no05a08 & 86.9 & 67.6 & \\
\hline 8 & ELL-14-06 & no05a08 & 87.6 & 68.1 & \\
\hline 9 & ELL-14-06 & no05a09 & 88.3 & 68.6 & 67.8 \\
\hline 10 & ELL-14-06 & no05a09 & 85.2 & 66.2 & \\
\hline 11 & ELL-14-06 & no05a09 & 88.1 & 68.5 & \\
\hline 12 & ELL-14-06 & no05a10 & 89.1 & 69.3 & 69.4 \\
\hline 13 & ELL-14-06 & no05a10 & 89.4 & 69.5 & \\
\hline 14 & ELL-14-06 & no05a10 & 89.3 & 69.4 & \\
\hline 15 & ELL-14-06 & no05a11 & 88.7 & 68.9 & 68.5 \\
\hline 16 & ELL-14-06 & no05a11 & 86.8 & 67.4 & \\
\hline 17 & ELL-14-06 & no05a11 & 88.9 & 69.1 & \\
\hline 18 & ELL-14-06 & no05a12 & 88.8 & 69.0 & 68.8 \\
\hline 19 & ELL-14-06 & no05a12 & 88.8 & 69.0 & \\
\hline 20 & ELL-14-06 & no05a12 & 87.9 & 68.3 & \\
\hline 21 & ELL-14-06 & no05a13 & 88.8 & 69.0 & 67.9 \\
\hline 22 & ELL-14-06 & no05a13 & 86.3 & 67.1 & \\
\hline 23 & ELL-14-06 & no05a13 & 87.0 & 67.6 & \\
\hline 24 & ELL-14-06 & no05a14 & 86.7 & 67.4 & 67.5 \\
\hline 25 & ELL-14-06 & no05a14 & 86.9 & 67.6 & \\
\hline 26 & ELL-14-06 & no05a14 & 86.9 & 67.5 & \\
\hline 27 & ELL-14-06 & no05a15 & 87.3 & 67.9 & 67.2 \\
\hline 28 & ELL-14-06 & no05a15 & 85.5 & 66.5 & \\
\hline 29 & ELL-14-06 & no05a15 & 86.5 & 67.2 & \\
\hline 30 & ELL-14-06 & no05a23 & 88.5 & 68.8 & 67.9 \\
\hline 31 & ELL-14-06 & no05a23 & 86.4 & 67.2 & \\
\hline 32 & ELL-14-06 & no05a23 & 87.3 & 67.8 & \\
\hline 33 & ELL-14-06 & no05a24 & 87.3 & 67.8 & 68.9 \\
\hline 34 & ELL-14-06 & no05a24 & 89.0 & 69.2 & \\
\hline 35 & ELL-14-06 & no05a24 & 89.6 & 69.7 & \\
\hline 36 & ELL-14-06 & no05a26 & 88.8 & 69.0 & 69.0 \\
\hline 37 & ELL-14-06 & no05a26 & 88.5 & 68.8 & \\
\hline 38 & ELL-14-06 & no05a26 & 89.1 & 69.2 & \\
\hline 39 & ELL-14-06 & no05a27 & 87.5 & 68.0 & 68.0 \\
\hline 40 & ELL-14-06 & no05a27 & 87.1 & 67.7 & \\
\hline 41 & ELL-14-06 & no05a27 & 88.1 & 68.4 & \\
\hline 42 & ELL-14-06 & no05a28 & 86.8 & 67.5 & 67.9 \\
\hline 43 & ELL-14-06 & no05a28 & 87.4 & 67.9 & \\
\hline 44 & ELL-14-06 & no05a28 & 88.0 & 68.4 & \\
\hline
\end{tabular}


Appendix IV. (Cont.)

\begin{tabular}{|c|c|c|c|c|c|}
\hline $\begin{array}{l}\text { Analysis } \\
\text { I.D. }\end{array}$ & Sample I.D. & $\begin{array}{l}\text { Ablation } \\
\text { Analysis }\end{array}$ & $\mathrm{FeO}$ wt. $\%$ & Fe wt. $\%$ & $\begin{array}{l}\text { Avg. Spot } \\
\text { Analysis }\end{array}$ \\
\hline 1 & ELL-14-06 & no05a06 & 85.9 & 66.8 & 67.4 \\
\hline 2 & ELL-14-06 & no05a06 & 86.4 & 67.1 & \\
\hline 3 & ELL-14-06 & no05a07 & 86.0 & 66.8 & 67.2 \\
\hline 4 & ELL-14-06 & no05a07 & 87.0 & 67.7 & \\
\hline 5 & ELL-14-06 & no05a07 & 86.5 & 67.3 & \\
\hline 6 & ELL-14-06 & no05a08 & 87.9 & 68.3 & 68.0 \\
\hline 7 & ELL-14-06 & no05a08 & 86.9 & 67.6 & \\
\hline 8 & ELL-14-06 & no05a08 & 87.6 & 68.1 & \\
\hline 9 & ELL-14-06 & no05a09 & 88.3 & 68.6 & 67.8 \\
\hline 10 & ELL-14-06 & no05a09 & 85.2 & 66.2 & \\
\hline 11 & ELL-14-06 & no05a09 & 88.1 & 68.5 & \\
\hline 12 & ELL-14-06 & no05a 10 & 89.1 & 69.3 & 69.4 \\
\hline 13 & ELL-14-06 & no05a 10 & 89.4 & 69.5 & \\
\hline 14 & ELL-14-06 & no05a 10 & 89.3 & 69.4 & \\
\hline 15 & ELL-14-06 & no05a11 & 88.7 & 68.9 & 68.5 \\
\hline 16 & ELL-14-06 & no05a11 & 86.8 & 67.4 & \\
\hline 17 & ELL-14-06 & no05a11 & 88.9 & 69.1 & \\
\hline 18 & ELL-14-06 & no05a12 & 88.8 & 69.0 & 68.8 \\
\hline 19 & ELL-14-06 & no05a12 & 88.8 & 69.0 & \\
\hline 20 & ELL-14-06 & no05a12 & 87.9 & 68.3 & \\
\hline 21 & ELL-14-06 & no05a13 & 88.8 & 69.0 & 67.9 \\
\hline 22 & ELL-14-06 & no05a 13 & 86.3 & 67.1 & \\
\hline 23 & ELL-14-06 & no05a13 & 87.0 & 67.6 & \\
\hline 24 & ELL-14-06 & no05a14 & 86.7 & 67.4 & 67.5 \\
\hline 25 & ELL-14-06 & no05a14 & 86.9 & 67.6 & \\
\hline 26 & ELL-14-06 & no05a14 & 86.9 & 67.5 & \\
\hline 27 & ELL-14-06 & no05a15 & 87.3 & 67.9 & 67.2 \\
\hline 28 & ELL-14-06 & no05a 15 & 85.5 & 66.5 & \\
\hline 29 & ELL-14-06 & no05a15 & 86.5 & 67.2 & \\
\hline 30 & ELL-14-06 & no05a23 & 88.5 & 68.8 & 67.9 \\
\hline 31 & ELL-14-06 & no05a23 & 86.4 & 67.2 & \\
\hline 32 & ELL-14-06 & no05a23 & 87.3 & 67.8 & \\
\hline 33 & ELL-14-06 & no05a24 & 87.3 & 67.8 & 68.9 \\
\hline 34 & ELL-14-06 & no05a24 & 89.0 & 69.2 & \\
\hline 35 & ELL-14-06 & no05a24 & 89.6 & 69.7 & \\
\hline 36 & ELL-14-06 & no05a26 & 88.8 & 69.0 & 69.0 \\
\hline 37 & ELL-14-06 & no05a26 & 88.5 & 68.8 & \\
\hline 38 & ELL-14-06 & no05a26 & 89.1 & 69.2 & \\
\hline 39 & ELL-14-06 & no05a27 & 87.5 & 68.0 & 68.0 \\
\hline 40 & ELL-14-06 & no05a27 & 87.0 & 67.7 & \\
\hline 41 & ELL-14-06 & no05a27 & 88.1 & 68.4 & \\
\hline 42 & ELL-14-06 & no05a28 & 86.8 & 67.5 & 67.9 \\
\hline 43 & ELL-14-06 & no05a28 & 87.4 & 67.9 & \\
\hline 44 & ELL-14-06 & no05a28 & 88.0 & 68.4 & \\
\hline
\end{tabular}


Appendix IV. (Cont.)

\begin{tabular}{|c|c|c|c|c|c|}
\hline $\begin{array}{c}\text { Analysis } \\
\text { I.D. }\end{array}$ & Sample I.D. & $\begin{array}{l}\text { Ablation } \\
\text { Analysis }\end{array}$ & FeO wt. $\%$ & Fe wt. $\%$ & $\begin{array}{c}\text { Avg. Spot } \\
\text { Analysis }\end{array}$ \\
\hline 10 & ELL-14-05 & no05c11 & 88.4 & 68.7 & 69.6 \\
\hline 11 & ELL-14-05 & no05c11 & 90.7 & 70.5 & \\
\hline 12 & ELL-14-05 & no05c11 & 89.6 & 69.7 & \\
\hline 13 & ELL-14-05 & no05c12 & 90.0 & 70.0 & 69.5 \\
\hline 14 & ELL-14-05 & no05c12 & 89.9 & 69.9 & \\
\hline 15 & ELL-14-05 & no05c13 & 88.4 & 68.7 & 68.1 \\
\hline 16 & ELL-14-05 & no $05 \mathrm{c} 13$ & 86.6 & 67.3 & \\
\hline 17 & ELL-14-05 & no05c13 & 87.7 & 68.2 & \\
\hline 18 & ELL-14-05 & no05c14 & 88.1 & 68.5 & 68.6 \\
\hline 19 & ELL-14-05 & no05c14 & 87.0 & 67.6 & \\
\hline 20 & ELL-14-05 & no05c14 & 89.5 & 69.5 & \\
\hline 21 & ELL-14-05 & no05c15 & 89.4 & 69.5 & 69.0 \\
\hline 22 & ELL-14-05 & no05c15 & 89.2 & 69.3 & \\
\hline 23 & ELL-14-05 & no05c15 & 87.5 & 68.0 & \\
\hline 24 & ELL-14-05 & no05c16 & 88.7 & 68.9 & 69.1 \\
\hline 25 & ELL-14-05 & no05c16 & 89.1 & 69.2 & \\
\hline 26 & ELL-14-05 & no0 $5 \mathrm{c} 16$ & 89.0 & 69.2 & \\
\hline 27 & ELL-14-05 & no0 $5 \mathrm{c} 17$ & 86.6 & 67.3 & 67.6 \\
\hline 28 & ELL-14-05 & no05c17 & 88.3 & 68.6 & \\
\hline 29 & ELL-14-05 & no $05 \mathrm{c} 17$ & 85.9 & 66.7 & \\
\hline 30 & ELL-14-05 & no05c18 & 85.3 & 66.3 & 67.9 \\
\hline 31 & ELL-14-05 & no05c18 & 88.9 & 69.1 & \\
\hline 32 & ELL-14-05 & no05c18 & 87.8 & 68.2 & \\
\hline 33 & ELL-14-05 & no05c22 & 87.5 & 68.0 & 68.4 \\
\hline 34 & ELL-14-05 & no05c22 & 88.1 & 68.5 & \\
\hline 35 & ELL-14-05 & no05c22 & 88.2 & 68.6 & \\
\hline 36 & ELL-14-05 & no0 $05 \mathrm{c} 23$ & 88.2 & 68.5 & 68.8 \\
\hline 37 & ELL-14-05 & no05c 23 & 87.6 & 68.1 & \\
\hline 38 & ELL-14-05 & no05c23 & 89.9 & 69.9 & \\
\hline 39 & ELL-14-05 & no05c24 & 89.1 & 69.2 & 69.5 \\
\hline 40 & ELL-14-05 & no05c 24 & 88.8 & 69.0 & \\
\hline 41 & ELL-14-05 & no05c24 & 90.3 & 70.2 & \\
\hline 42 & ELL-14-05 & no0 $5 \mathrm{c} 25$ & 89.3 & 69.4 & 69.4 \\
\hline 43 & ELL-14-05 & no05c25 & 89.4 & 69.5 & \\
\hline 44 & ELL-14-05 & no05c25 & 89.1 & 69.2 & \\
\hline 45 & ELL-14-05 & no05c26 & 87.9 & 68.4 & 69.4 \\
\hline 46 & ELL-14-05 & no05c26 & 89.8 & 69.8 & \\
\hline 47 & ELL-14-05 & no05c26 & 90.0 & 70.0 & \\
\hline 48 & ELL-14-05 & no05c27 & 88.8 & 69.0 & 69.2 \\
\hline 49 & ELL-14-05 & no0 0527 & 89.2 & 69.3 & \\
\hline 50 & ELL-14-05 & no05c28 & 88.1 & 68.5 & 68.5 \\
\hline 51 & ELL-14-05 & no05c28 & 88.2 & 68.5 & \\
\hline
\end{tabular}


Appendix IV. (Cont.)

\begin{tabular}{|c|c|c|c|c|c|}
\hline $\begin{array}{c}\text { Analysis } \\
\text { I.D. }\end{array}$ & Sample I.D. & $\begin{array}{l}\text { Ablation } \\
\text { Analysis }\end{array}$ & FeO wt. $\%$ & Fe wt. $\%$ & $\begin{array}{c}\text { Avg. Spot } \\
\text { Analysis }\end{array}$ \\
\hline 45 & ELL-14-06 & no05a18 & 89.9 & 69.9 & 69.4 \\
\hline 46 & ELL-14-06 & no05a18 & 88.3 & 68.7 & \\
\hline 47 & ELL-14-06 & no05a18 & 89.8 & 69.8 & \\
\hline 48 & ELL-14-06 & no05a19 & 89.0 & 69.1 & 69.1 \\
\hline 49 & ELL-14-06 & no05a19 & 89.0 & 69.2 & \\
\hline 50 & ELL-14-06 & no05a19 & 89.0 & 69.0 & \\
\hline 51 & ELL-14-06 & no05a20 & 85.6 & 66.5 & 67.4 \\
\hline 52 & ELL-14-06 & no05a20 & 89.0 & 69.1 & \\
\hline 53 & ELL-14-06 & no05a20 & 86.0 & 66.7 & \\
\hline 54 & ELL-14-06 & no05a21 & 89.1 & 69.2 & 68.6 \\
\hline 55 & ELL-14-06 & no05a21 & 86.6 & 67.3 & \\
\hline 56 & ELL-14-06 & no05a21 & 89.1 & 69.3 & \\
\hline 57 & ELL-14-06 & no05a22 & 85.6 & 66.5 & 66.8 \\
\hline 58 & ELL-14-06 & no05a22 & 86.2 & 67.0 & \\
\hline 59 & ELL-14-06 & no05a22 & 86.0 & 66.9 & \\
\hline 1 & LAS-14-07 & no05d 21 & 79.8 & 62.0 & 61.9 \\
\hline 2 & LAS-14-07 & $\operatorname{no} 05 \mathrm{~d} 21$ & 79.6 & 61.9 & \\
\hline 3 & LAS-14-07 & no05d 21 & 79.4 & 61.7 & \\
\hline 4 & LAS-14-07 & $\mathrm{no} 05 \mathrm{~d} 22$ & 79.7 & 61.9 & 61.8 \\
\hline 5 & LAS-14-07 & no05d22 & 79.5 & 61.8 & \\
\hline 6 & LAS-14-07 & no05d22 & 79.3 & 61.6 & \\
\hline 7 & LAS-14-07 & no05d 23 & 78.4 & 60.9 & 61.3 \\
\hline 8 & LAS-14-07 & no0 $05 \mathrm{~d} 23$ & 78.8 & 61.3 & \\
\hline 9 & LAS-14-07 & no0 $05 \mathrm{~d} 23$ & 79.4 & 61.7 & \\
\hline 10 & LAS-14-07 & no05d24 & 79.3 & 61.6 & 61.9 \\
\hline 11 & LAS-14-07 & no05d24 & 79.8 & 62.1 & \\
\hline 12 & LAS-14-07 & no05d24 & 79.8 & 62.0 & \\
\hline 13 & LAS-14-07 & no05d 27 & 79.9 & 62.1 & 58.9 \\
\hline 14 & LAS-14-07 & $\mathrm{no} 05 \mathrm{~d} 27$ & 79.2 & 61.5 & \\
\hline 15 & LAS-14-07 & $\mathrm{no} 05 \mathrm{~d} 27$ & 68.3 & 53.1 & \\
\hline 16 & LAS-14-07 & no05d30 & 79.5 & 61.8 & 61.5 \\
\hline 17 & LAS-14-07 & $\mathrm{no} 05 \mathrm{~d} 30$ & 79.4 & 61.7 & \\
\hline 18 & LAS-14-07 & no05d30 & 78.6 & 61.1 & \\
\hline 19 & LAS-14-07 & no05d33 & 80.9 & 62.9 & 62.1 \\
\hline 20 & LAS-14-07 & no05d33 & 80.1 & 62.3 & \\
\hline 21 & LAS-14-07 & no0 $0 \mathrm{~d} 33$ & 78.7 & 61.2 & \\
\hline 22 & LAS-14-07 & no05d34 & 80.0 & 62.1 & 62.3 \\
\hline 23 & LAS-14-07 & no05d34 & 79.9 & 62.1 & \\
\hline 24 & LAS-14-07 & no05d34 & 80.7 & 62.7 & \\
\hline
\end{tabular}


Appendix V. LA-ICPMS spot analysis results. Fe (wt. \%) is the mean concentrations of three or less EPMA analyses in the vicinity of LA-ICPMS spots. Spot locations are shown on BSE images of magnetite grains in Appendix VI.

\begin{tabular}{|c|c|c|c|c|c|c|c|c|c|c|c|c|c|c|c|c|c|c|}
\hline Sample & Rock type & $\begin{array}{c}\text { Grain } \\
\#\end{array}$ & $\begin{array}{c}\text { LA- } \\
\text { ICPMS } \\
\text { spot }\end{array}$ & $\begin{array}{l}\text { Fe wt. \% } \\
\text { (EPMA) }\end{array}$ & ${ }^{24} \mathrm{Mg}$ & ${ }^{27} \mathrm{Al}$ & ${ }^{29} \mathrm{Si}$ & ${ }^{31} \mathrm{P}$ & ${ }^{34} \mathrm{~S}$ & ${ }^{44} \mathrm{Ca}$ & ${ }^{47} \mathrm{Ti}$ & ${ }^{51} \mathrm{~V}$ & ${ }^{52} \mathrm{Cr}$ & ${ }^{55} \mathrm{Mn}$ & ${ }^{59} \mathrm{Co}$ & ${ }^{60} \mathrm{Ni}$ & ${ }^{63} \mathrm{Cu}$ & ${ }^{66} \mathrm{Zn}$ \\
\hline \multirow[t]{6}{*}{ KRN-10-02 } & high $\mathrm{P}$ ore & 1 & ap22a08 & 70 & 113 & & & & 140 & & & 1464 & & 352 & 94 & 269 & & 15 \\
\hline & & 1 & ap22a09 & 70 & 110 & & & & 350 & & & 1454 & 33 & 365 & 94 & 244 & & 15 \\
\hline & & 1 & ap22a10 & 70 & 2490 & 38 & 5870 & & 430 & & & 1422 & 90 & 384 & 97 & 247 & & 21 \\
\hline & & 1 & ap22a11 & 70 & 1340 & & 2870 & & & & & 1417 & & 369 & 95 & 259 & & 15 \\
\hline & & 2 & ap22a12 & 70 & 329 & & 2120 & 312 & 940 & 860 & 61 & 1426 & 87 & 426 & 96 & 255 & & 39 \\
\hline & & 2 & ap22a13 & 70 & 202 & & & 38 & 310 & & & 1449 & & 372 & 95 & 261 & & 18 \\
\hline \multirow[t]{7}{*}{$\mathrm{K}-1$} & high $\mathrm{P}$ ore & 1 & ap22a14 & 70 & 840 & 420 & 2130 & & & & & 1531 & & 364 & 120 & 270 & & 22 \\
\hline & & 1 & ap22a16 & 70 & 600 & 410 & 2840 & 42 & 320 & & 106 & 1539 & 51 & 376 & 119 & 269 & & 20 \\
\hline & & 1 & ap22a17 & 70 & 18 & & & 34 & & & 49 & 1517 & & 361 & 119 & 256 & & 14 \\
\hline & & 1 & ap22a25 & 69 & 24 & & 940 & & 260 & & & 1507 & 85 & 347 & 115 & 262 & & 15 \\
\hline & & 2 & ap22a26 & 70 & 31 & & & & & & & 1529 & & 366 & 118 & 259 & & 17 \\
\hline & & 2 & ap22a 27 & 70 & 87 & 124 & 940 & & 300 & & 76 & 1504 & 53 & 354 & 114 & 251 & & 15 \\
\hline & & 2 & ap22a28 & 70 & 143 & 99 & 800 & & & & & 1552 & & 359 & 118 & 256 & & 16 \\
\hline \multirow[t]{9}{*}{ K-2 } & low $\mathrm{P}$ ore & 1 & ap22a29 & 70 & 47 & & & 158 & 180 & 440 & 44 & 884 & & 315 & 64 & 166 & & 13 \\
\hline & & 1 & ap22a30 & 70 & 50 & 31 & 910 & & 520 & & & 878 & 70 & 318 & 64 & 167 & & 13 \\
\hline & & 1 & ap22a31 & 70 & 106 & 43 & & 106 & 430 & & & 892 & & 337 & 69 & 163 & & 19 \\
\hline & & 2 & ap22a32 & 70 & 115 & & 960 & & 540 & & & 883 & 28 & 338 & 66 & 165 & & 22 \\
\hline & & 2 & ap22a33 & 70 & 42 & & & & 170 & & 74 & 901 & & 327 & 67 & 159 & & 15 \\
\hline & & 2 & ap22a34 & 70 & 136 & 47 & 970 & & 470 & & 66 & 880 & 42 & 324 & 65 & 152 & & 12 \\
\hline & & 3 & ap22a42 & 70 & 68 & & & & 410 & & 70 & 873 & & 306 & 66 & 150 & & 17 \\
\hline & & 3 & ap22a43 & 70 & 102 & & & & 820 & & & 890 & & 310 & 65 & 158 & & 15 \\
\hline & & 3 & ap22a44 & 70 & 39 & 35 & & & 150 & & & 889 & & 313 & 63 & 181 & & 14 \\
\hline \multirow[t]{7}{*}{ KRN-11-01 } & high $\mathrm{P}$ ore & 1 & ap22a46 & 70 & 20 & & & & 360 & & 163 & 1283 & & 379 & 33 & & & 15 \\
\hline & & 1 & ap22a47 & 70 & 77 & 247 & 800 & & & & & 1284 & & 387 & 34 & & & 18 \\
\hline & & 2 & ap22a48 & 70 & 23 & 70 & & & 500 & & & 1277 & 69 & 467 & 34 & & & 20 \\
\hline & & 3 & ap22a49 & 70 & & & & & & & 254 & 1227 & 140 & 377 & 37 & & & 11 \\
\hline & & 3 & ap22a50 & 70 & & & & & 750 & & & 1250 & & 369 & 37 & & & \\
\hline & & 3 & ap22a51 & 70 & 95 & 139 & 4380 & 297 & 830 & & & 1265 & & 452 & 37 & & & 12 \\
\hline & & 3 & ap22a60 & 70 & & & & & 620 & & & 1260 & & 366 & 35 & & & 16 \\
\hline
\end{tabular}


Appendix V. (Cont.)

\begin{tabular}{|c|c|c|c|c|c|c|c|c|c|c|c|c|c|c|c|c|c|}
\hline Sample & Rock type & Grain \# & $\begin{array}{l}\text { LA- } \\
\text { ICPMS } \\
\text { spot }\end{array}$ & ${ }^{71} \mathrm{Ga}$ & ${ }^{75} \mathrm{As}$ & ${ }^{88} \mathrm{Sr}$ & ${ }^{89} \mathrm{Y}$ & ${ }^{93} \mathrm{Nb}$ & ${ }^{118} \mathrm{Sn}$ & ${ }^{139} \mathrm{La}$ & ${ }^{140} \mathrm{Ce}$ & ${ }^{141} \operatorname{Pr}$ & ${ }^{146} \mathrm{Nd}$ & ${ }^{147} \mathrm{Sm}$ & ${ }^{153} \mathrm{Eu}$ & ${ }^{157} \mathrm{Gd}$ & ${ }^{159} \mathrm{~Tb}$ \\
\hline \multirow{6}{*}{ KRN-10-02 } & high $\mathrm{P}$ ore & 1 & ap22a08 & 5.1 & 0.7 & & 0.4 & 0.1 & & 0.4 & 1.2 & 0.1 & 0.6 & 0.2 & 0.0 & & \\
\hline & & 1 & ap22a09 & 5.0 & 1.5 & & 1.0 & 0.2 & 0.8 & 1.0 & 2.5 & 0.3 & 1.4 & & & & 0.1 \\
\hline & & 1 & ap22a10 & 6.2 & 4.0 & 0.7 & 3.3 & 0.4 & 2.7 & 3.0 & 9.0 & 1.1 & 4.2 & 0.9 & & & 0.1 \\
\hline & & 1 & ap22a11 & 5.2 & 0.9 & & 0.8 & 0.2 & & 0.4 & 1.2 & 0.1 & 0.4 & & & & \\
\hline & & 2 & ap22a12 & 5.8 & 3.8 & 3.1 & 4.0 & 0.8 & 2.0 & 11.0 & 19.3 & 2.2 & 7.5 & 1.4 & 0.2 & 1.3 & 0.2 \\
\hline & & 2 & ap22a13 & 5.9 & 1.1 & 0.8 & 0.8 & 0.1 & & 9.2 & 12.3 & 0.9 & 2.5 & 0.2 & & & \\
\hline \multirow[t]{7}{*}{ K-1 } & high $\mathrm{P}$ ore & 1 & ap22a14 & 1.7 & & & 0.3 & 0.2 & & 0.3 & 0.7 & 0.1 & 0.2 & & & & \\
\hline & & 1 & ap22a16 & 1.8 & 1.6 & 1.6 & 0.3 & 0.4 & 1.1 & 1.0 & 2.0 & 0.3 & 0.6 & 0.1 & & & 0.0 \\
\hline & & 1 & ap22a17 & 1.5 & & & & & & & 0.1 & & & & & & 0.0 \\
\hline & & 1 & ap22a25 & 1.8 & & 0.4 & & & & 0.1 & 0.1 & 0.1 & 0.6 & & & & \\
\hline & & 2 & ap22a26 & 1.6 & & & & & & & 0.3 & & & & & & \\
\hline & & 2 & ap22a27 & 1.9 & & & 0.3 & 1.9 & 1.0 & 0.1 & 0.3 & 0.0 & 0.2 & 0.0 & & & \\
\hline & & 2 & ap22a28 & 1.7 & & 1.5 & 0.2 & 0.2 & & 0.2 & 0.5 & & 0.3 & 0.3 & & & \\
\hline \multirow[t]{9}{*}{ K-2 } & low $\mathrm{P}$ ore & 1 & ap22a29 & 11.5 & & 1.1 & 0.3 & & & 4.6 & 8.1 & 1.3 & 2.3 & 0.7 & 0.0 & & \\
\hline & & 1 & ap22a30 & 12.3 & 0.7 & 0.9 & 0.1 & & & 0.7 & 2.0 & 0.2 & 2.2 & & & & 0.0 \\
\hline & & 1 & ap22a31 & 11.7 & 0.9 & 3.1 & 0.4 & & & 2.3 & 2.6 & 0.2 & 1.4 & 0.2 & & & 0.1 \\
\hline & & 2 & ap22a32 & 11.7 & & 1.0 & 0.1 & & & 0.6 & 1.1 & 0.5 & 0.4 & & & & \\
\hline & & 2 & ap22a33 & 11.8 & 0.7 & 0.3 & 0.4 & & & 1.7 & 3.2 & 0.3 & 1.2 & 0.1 & & & \\
\hline & & 2 & ap22a34 & 11.4 & & 0.9 & 0.2 & & & 1.0 & 1.7 & 0.2 & 0.6 & 0.2 & & & 0.0 \\
\hline & & 3 & ap22a42 & 12.6 & & 1.0 & & & & 0.3 & 2.5 & 0.1 & 0.3 & & & & \\
\hline & & 3 & ap22a43 & 11.7 & & 2.9 & 0.3 & & & 1.2 & 2.2 & 0.2 & 0.8 & & & & \\
\hline & & 3 & ap22a44 & 10.7 & 0.6 & 0.3 & & & & 0.2 & 0.6 & 0.1 & 0.1 & & & & \\
\hline \multirow[t]{7}{*}{ KRN-11-01 } & high $\mathrm{P}$ ore & 1 & ap22a46 & 3.1 & & & & & 0.9 & 0.1 & 0.2 & & & & & & \\
\hline & & 1 & ap22a47 & 2.9 & & & & & & 0.3 & 0.5 & 0.0 & & 0.1 & & & \\
\hline & & 2 & ap22a48 & 3.2 & & & & & & & 0.0 & & 0.0 & & & & 0.0 \\
\hline & & 3 & ap22a49 & 3.8 & & & & 0.2 & 2.4 & & 0.5 & 0.0 & & & & & \\
\hline & & 3 & ap22a50 & 3.3 & & & & & & & 0.4 & & & & & & \\
\hline & & 3 & ap22a51 & 3.3 & & & & 2.2 & 7.4 & & & & & 0.1 & & & \\
\hline & & 3 & ap22a60 & 4.2 & & & & & & & & & & & & & \\
\hline
\end{tabular}


Appendix V. (Cont.)

\begin{tabular}{|c|c|c|c|c|c|c|c|c|c|c|c|c|c|c|c|c|}
\hline Sample & Rock type & Grain \# & $\begin{array}{c}\text { LA- } \\
\text { ICPMS } \\
\text { spot }\end{array}$ & ${ }^{163} \mathrm{Dy}$ & ${ }^{165} \mathrm{Ho}$ & ${ }^{166} \mathrm{Er}$ & ${ }^{169} \mathrm{Tm}$ & ${ }^{172} \mathrm{Yb}$ & ${ }^{175} \mathrm{Lu}$ & ${ }^{178} \mathrm{Hf}$ & ${ }^{181} \mathrm{Ta}$ & ${ }^{197} \mathrm{Au}$ & ${ }^{205} \mathrm{Tl}$ & ${ }^{208} \mathrm{~Pb}$ & ${ }^{232} \mathrm{Th}$ & ${ }^{238} \mathrm{U}$ \\
\hline \multirow{6}{*}{ KRN-10-02 } & high $\mathrm{P}$ ore & 1 & ap22a08 & & & & & & & & & & & 0.2 & 0.2 & 0.1 \\
\hline & & 1 & ap22a09 & 0.2 & 0.0 & 0.0 & & 0.0 & & 0.0 & & & & 0.5 & 0.7 & 0.3 \\
\hline & & 1 & ap22a10 & 0.5 & 0.1 & 0.2 & & 0.1 & & & & & & 3.7 & 2.2 & 0.4 \\
\hline & & 1 & ap22a11 & 0.1 & 0.0 & & & & & 0.0 & & & & 2.5 & 0.5 & 0.3 \\
\hline & & 2 & ap22a12 & 0.7 & 0.1 & 0.3 & 0.0 & 0.1 & 0.0 & & & & & 2.2 & 1.9 & 1.0 \\
\hline & & 2 & ap22a13 & 0.1 & 0.0 & & & & & & & & & 0.6 & 1.9 & 0.0 \\
\hline \multirow[t]{7}{*}{ K-1 } & high $\mathrm{P}$ ore & 1 & ap22a14 & & 0.0 & 0.0 & & & & & & & 0.0 & & 0.0 & 0.1 \\
\hline & & 1 & ap22a16 & & & & 0.0 & 0.0 & & 0.0 & 0.1 & & & 0.3 & 0.4 & 0.6 \\
\hline & & 1 & ap22a17 & & & & & & & & & & & & & 0.0 \\
\hline & & 1 & ap22a25 & & & & & & & & & 0.0 & & 0.1 & 0.0 & 0.0 \\
\hline & & 2 & ap $22 \mathrm{a} 26$ & & & & & & & 0.0 & & & & & 0.0 & 0.1 \\
\hline & & 2 & ap22a27 & & & 0.0 & & 0.0 & & & 0.1 & & & & 0.1 & 0.1 \\
\hline & & 2 & ap22a28 & 0.0 & 0.0 & 0.0 & & & & & & & 0.0 & 0.7 & 0.1 & 0.2 \\
\hline \multirow[t]{9}{*}{$\mathrm{K}-2$} & low $\mathrm{P}$ ore & 1 & ap22a29 & 0.2 & & 0.0 & & 0.0 & & & & & & 0.3 & 0.7 & 0.0 \\
\hline & & 1 & ap22a30 & 0.0 & & & & & & & & & 0.0 & 0.4 & 0.5 & \\
\hline & & 1 & ap22a31 & 0.1 & & 0.0 & 0.0 & & & & & & & 0.3 & 0.4 & 0.1 \\
\hline & & 2 & ap22a32 & 0.0 & & & & 0.0 & & & & & & 1.0 & 0.3 & 0.1 \\
\hline & & 2 & ap22a33 & & & & 0.0 & & & & & 0.0 & 0.0 & 0.5 & 1.4 & 0.1 \\
\hline & & 2 & ap22a34 & 0.0 & & & & & & 0.0 & & & & 0.3 & 0.5 & 0.0 \\
\hline & & 3 & ap $22 \mathrm{a} 42$ & 0.0 & & & & & & & & & 0.0 & 0.4 & 0.3 & 0.0 \\
\hline & & 3 & ap22a43 & & & & & 0.0 & & & & & & 0.1 & 1.0 & 0.1 \\
\hline & & 3 & ap22a44 & & & & & 0.0 & & & & & & 0.2 & 0.2 & 0.0 \\
\hline \multirow[t]{7}{*}{ KRN-11-01 } & high $\mathrm{P}$ ore & 1 & ap22a46 & 0.0 & & & & & & & & & & & & 0.0 \\
\hline & & 1 & ap22a47 & & & & & & & & & 0.0 & & 0.2 & 0.0 & 0.0 \\
\hline & & 2 & ap22a48 & & & & & & & & & & & 0.1 & 0.0 & \\
\hline & & 3 & ap22a49 & & & & & & & & & & & & & \\
\hline & & 3 & ap22a50 & & & & & & & & & & & & & \\
\hline & & 3 & ap22a51 & 0.0 & & & 0.1 & 1.3 & & & & & 0.0 & & & 0.6 \\
\hline & & 3 & ap22a60 & & & & & & & & & & & & & \\
\hline
\end{tabular}


Appendix V. (Cont.)

\begin{tabular}{|c|c|c|c|c|c|c|c|c|c|c|c|c|c|c|c|c|c|c|}
\hline Sample & Rock type & Grain \# & $\begin{array}{l}\text { LA- } \\
\text { ICPMS } \\
\text { spot }\end{array}$ & $\begin{array}{l}\text { Fe wt. \% } \\
\text { (EPMA) }\end{array}$ & ${ }^{24} \mathrm{Mg}$ & ${ }^{27} \mathrm{Al}$ & ${ }^{29} \mathrm{Si}$ & ${ }^{31} \mathrm{P}$ & ${ }^{34} \mathrm{~S}$ & ${ }^{44} \mathrm{Ca}$ & ${ }^{47} \mathrm{Ti}$ & ${ }^{51} \mathrm{~V}$ & ${ }^{52} \mathrm{Cr}$ & ${ }^{55} \mathrm{Mn}$ & ${ }^{59} \mathrm{Co}$ & ${ }^{60} \mathrm{Ni}$ & ${ }^{63} \mathrm{Cu}$ & ${ }^{66} \mathrm{Zn}$ \\
\hline \multirow[t]{5}{*}{ KRN-11-03 } & andesite & 1 & ap22a80 & 70 & 41 & & & & 250 & & & 803 & 85 & 585 & 35 & & & 29 \\
\hline & (LA-FW) & 1 & ap22a81 & 70 & 54 & & & & & & & 802 & 60 & 640 & 35 & & & 33 \\
\hline & & 1 & ap22a82 & 70 & 94 & 106 & 730 & 20 & 360 & & & 790 & 96 & 600 & 35 & & & 33 \\
\hline & & 2 & ap22a83 & 70 & 66 & 112 & 970 & & & & & 735 & 76 & 621 & 35 & & & 24 \\
\hline & & 2 & ap22a84 & 70 & 69 & 74 & & & & & & 731 & 79 & 627 & 33 & & & 23 \\
\hline \multirow[t]{7}{*}{ KRN-11-04 } & andesite & 1 & ap22a85 & 70 & 90 & 33 & 810 & & & & & 977 & 52 & 370 & 42 & 52 & & 20 \\
\hline & (A-FW) & 1 & ap22a86 & 71 & 31 & & & & & & & 996 & & 383 & 45 & & & 15 \\
\hline & & 1 & ap22a87 & 71 & 20 & & 620 & & 380 & & & 989 & 96 & 388 & 45 & 35 & & 12 \\
\hline & & 1 & ap23a05 & 70 & 15 & & 820 & & & & 50 & 986 & 91 & 364 & 44 & 41 & & 15 \\
\hline & & 1 & ap23a06 & 70 & 39 & & & & & & 85 & 983 & & 363 & 42 & 25 & & 17 \\
\hline & & 2 & ap23a07 & 70 & 112 & 64 & 1380 & & 460 & 660 & 71 & 992 & & 374 & 43 & 34 & & 22 \\
\hline & & 2 & ap23a08 & 70 & 320 & 180 & & & & & 67 & 976 & & 391 & 43 & 30 & & 20 \\
\hline \multirow[t]{2}{*}{ KRN-11-05 } & rhyodacite & 1 & ap23a09 & 70 & & 37 & 1600 & 31 & 390 & & & 167 & 101 & 288 & 23 & & & 7 \\
\hline & (HW) & 2 & ap23a10 & 70 & & 129 & & & 250 & & & 185 & & 272 & 24 & & & 6 \\
\hline \multirow[t]{3}{*}{ KRN-12-02 } & aplite vein & & ap23a11 & 70 & 56 & & & & & 330 & & 1801 & & 282 & 37 & 64 & & 16 \\
\hline & & & ap23a12 & 70 & & & 850 & 36 & 430 & & 50 & 1727 & 103 & 296 & 38 & 44 & & 19 \\
\hline & & & ap23a13 & 70 & 31 & 44 & & & 220 & & & 1705 & 44 & 245 & 36 & 54 & & 14 \\
\hline \multirow[t]{7}{*}{ KRN-12-03 } & syenite & 1 & ap23a14 & 70 & 77 & 116 & 2970 & 37 & 670 & & & 885 & 83 & 341 & 41 & & & 24 \\
\hline & & 1 & ap23a24 & 70 & & & & & 230 & & & 955 & & 448 & 43 & & & 32 \\
\hline & & 1 & ap23a25 & 70 & & & 1220 & & 290 & & & 943 & 68 & 417 & 42 & & & 30 \\
\hline & & 2 & ap23a27 & 70 & 19 & & & & 260 & 360 & 42 & 966 & & 438 & 43 & & & 36 \\
\hline & & 2 & ap23a28 & 70 & 123 & & 2230 & & 490 & 500 & 204 & 967 & 128 & 443 & 44 & & & 35 \\
\hline & & 3 & ap23a29 & 70 & & & & & & & & 1023 & & 440 & 44 & & & 33 \\
\hline & & 3 & ap23a30 & 70 & 16 & & & & & & & 1012 & & 472 & 44 & & & 36 \\
\hline \multirow[t]{2}{*}{ KRN-12-05 } & granite & 1 & ap23a31 & 70 & & & 1130 & 355 & 1400 & 1050 & & 296 & 437 & 87 & 12 & & 23 & 13 \\
\hline & & 2 & ap23a40 & 70 & 39 & 166 & & 36 & 350 & & & 351 & 424 & 102 & 8 & & 5 & 9 \\
\hline \multirow[t]{2}{*}{ TUV-10-03 } & rhyodacite & 1 & ap23a61 & 70 & 15 & 43 & & & 260 & & & 654 & 47 & 228 & 70 & 84 & & 5 \\
\hline & host & 2 & ap23a63 & 70 & 13 & & & & 250 & & & 555 & & 253 & 84 & 69 & & 7 \\
\hline
\end{tabular}


Appendix V. (Cont.)

\begin{tabular}{|c|c|c|c|c|c|c|c|c|c|c|c|c|c|c|c|c|c|}
\hline Sample & Rock type & Grain \# & $\begin{array}{c}\text { LA-ICPMS } \\
\text { spot }\end{array}$ & ${ }^{71} \mathrm{Ga}$ & ${ }^{75} \mathrm{As}$ & ${ }^{88} \mathrm{Sr}$ & ${ }^{89} \mathrm{Y}$ & ${ }^{93} \mathrm{Nb}$ & ${ }^{118} \mathrm{Sn}$ & ${ }^{139} \mathrm{La}$ & ${ }^{140} \mathrm{Ce}$ & ${ }^{141} \mathrm{Pr}$ & ${ }^{146} \mathrm{Nd}$ & ${ }^{147} \mathrm{Sm}$ & ${ }^{153} \mathrm{Eu}$ & ${ }^{157} \mathrm{Gd}$ & ${ }^{159} \mathrm{~Tb}$ \\
\hline \multirow[t]{5}{*}{ KRN-11-03 } & andesite & 1 & ap22a80 & 17.8 & & & & & & & & & & & & & \\
\hline & (LA-FW) & 1 & ap22a81 & 18.4 & & 0.5 & & & & 0.1 & 0.3 & 0.0 & 0.7 & & & & \\
\hline & & 1 & ap22a82 & 18.5 & & 5.7 & 0.2 & 0.1 & & 0.3 & 0.1 & & 0.0 & & & & 0.3 \\
\hline & & 2 & ap22a83 & 14.7 & & 0.3 & & & & 0.5 & 0.4 & & & 0.1 & & & \\
\hline & & 2 & ap22a84 & 15.5 & & & 0.9 & & & 0.2 & 0.2 & 0.1 & & & & & \\
\hline \multirow[t]{7}{*}{ KRN-11-04 } & andesite & 1 & ap22a85 & 9.7 & & 1.0 & & & & & & & & & & & \\
\hline & $(\mathrm{A}-\mathrm{FW})$ & 1 & ap22a86 & 10.4 & & & & & & 0.2 & & & & & & & \\
\hline & & 1 & ap22a87 & 9.5 & & & & & & & 0.2 & & 0.0 & & & & \\
\hline & & 1 & ap23a05 & 9.8 & & & & & 0.5 & & & & & & & & \\
\hline & & 1 & ap23a06 & 10.0 & & 0.8 & & & & 0.3 & 0.2 & 0.1 & & & 0.1 & & \\
\hline & & 2 & ap23a07 & 10.6 & & 1.7 & & & & 0.1 & 0.3 & 0.1 & 0.3 & 0.1 & & & \\
\hline & & 2 & ap23a08 & 10.3 & & & & & & & 0.2 & 0.0 & & & & & \\
\hline \multirow{2}{*}{ KRN-11-05 } & rhyodacite & 1 & ap23a09 & 7.9 & & & & & & & 0.1 & 0.0 & & & & & \\
\hline & (HW) & 2 & ap23a10 & 6.0 & & & 1.1 & & & 0.1 & 0.1 & & 0.2 & & & & \\
\hline \multirow[t]{3}{*}{ KRN-12-02 } & aplite vein & & ap23a11 & 14.6 & & 0.9 & & & & & 0.0 & & 0.1 & 0.1 & & & \\
\hline & & & ap23a12 & 13.0 & & 1.3 & & & & 0.2 & 0.3 & & 0.1 & & & & \\
\hline & & & ap23a13 & 14.0 & & 2.0 & 0.2 & & & 0.3 & 0.3 & & 0.4 & & & & \\
\hline \multirow[t]{7}{*}{ KRN-12-03 } & syenite & 1 & ap23a14 & 4.8 & & & 0.2 & & & 0.7 & 0.3 & & 0.2 & & & & \\
\hline & & 1 & ap23a24 & 4.5 & & & & & & 0.1 & & & & & & & \\
\hline & & 1 & ap23a25 & 4.2 & & & & & & & 0.1 & & 0.1 & & & & \\
\hline & & 2 & ap23a27 & 4.1 & & 0.7 & 0.1 & & & 0.1 & 0.1 & & 0.1 & & & & \\
\hline & & 2 & ap23a28 & 4.3 & & 0.8 & 2.2 & 0.3 & & 0.4 & 1.7 & 0.1 & & & & & 0.1 \\
\hline & & 3 & ap23a29 & 4.4 & & 0.7 & 0.1 & & & & 0.1 & & & & & & \\
\hline & & 3 & ap23a30 & 4.3 & & 0.6 & 0.1 & & & 0.1 & & & & & & & \\
\hline \multirow{2}{*}{ KRN-12-05 } & granite & 1 & ap23a31 & 10.3 & & & 0.4 & & & 1.9 & 5.2 & 0.4 & 1.5 & & 0.1 & & \\
\hline & & 2 & ap23a40 & 11.2 & & & & & & 0.4 & 0.4 & & & & & & \\
\hline \multirow[t]{2}{*}{ TUV-10-03 } & rhyodacite & 1 & ap23a61 & 14.4 & & & & & & & 0.1 & & 0.1 & & & & \\
\hline & host & 2 & ap23a63 & 12.8 & & & & & & 0.1 & & & & & & & \\
\hline
\end{tabular}


Appendix V. (Cont.)

\begin{tabular}{|c|c|c|c|c|c|c|c|c|c|c|c|c|c|c|c|c|}
\hline Sample & Rock type & Grain \# & $\begin{array}{c}\text { LA- } \\
\text { ICPMS } \\
\text { spot } \\
\end{array}$ & ${ }^{163}$ Dy & ${ }^{165} \mathrm{Ho}$ & ${ }^{166} \mathrm{Er}$ & ${ }^{169} \mathrm{Tm}$ & ${ }^{172} \mathrm{Yb}$ & ${ }^{175} \mathrm{Lu}$ & ${ }^{178} \mathrm{Hf}$ & ${ }^{181} \mathrm{Ta}$ & ${ }^{197} \mathrm{Au}$ & ${ }^{205} \mathrm{Tl}$ & ${ }^{208} \mathrm{~Pb}$ & ${ }^{232} \mathrm{Th}$ & ${ }^{238} \mathrm{U}$ \\
\hline \multirow{5}{*}{ KRN-11-03 } & andesite & 1 & ap22a80 & & & & & & & & & & & 0.1 & 0.0 & 0.0 \\
\hline & (LA-FW) & 1 & ap22a81 & & & & & & & 0.0 & & & & & 0.0 & 0.0 \\
\hline & & 1 & ap22a82 & & & & & & & & & & & 0.1 & 0.0 & 0.0 \\
\hline & & 2 & ap22a83 & 0.0 & & & & & & 0.0 & & & & & & 0.0 \\
\hline & & 2 & ap22a84 & & & & & & & & & & & 1.0 & 0.0 & 0.0 \\
\hline \multirow[t]{7}{*}{ KRN-11-04 } & andesite & 1 & ap22a85 & & & & & & & & & & & 0.3 & & \\
\hline & (A-FW) & 1 & ap22a86 & & & 0.0 & & & & 0.0 & & & & & 0.0 & 0.0 \\
\hline & & 1 & ap22a87 & & & & & & & & & & & & 0.0 & 0.0 \\
\hline & & 1 & ap23a05 & & & & & & & & & & & 0.1 & 0.0 & \\
\hline & & 1 & ap23a06 & & & & & & & & & & 0.0 & 0.1 & 0.0 & 0.0 \\
\hline & & 2 & ap23a07 & & & & 0.0 & & & & & 0.0 & 0.0 & 0.2 & 0.2 & 0.1 \\
\hline & & 2 & ap23a08 & 0.0 & & & & & & 0.0 & & & & 0.2 & 0.0 & 0.0 \\
\hline \multirow[t]{2}{*}{ KRN-11-05 } & rhyodacite & 1 & ap23a09 & & & & & & & & & & & 0.1 & & 0.0 \\
\hline & (HW) & 2 & ap23a10 & 0.2 & 0.0 & 0.2 & & 0.5 & 0.1 & 1.9 & 0.0 & & & 0.1 & 0.1 & 0.8 \\
\hline \multirow[t]{3}{*}{ KRN-12-02 } & aplite vein & & ap23a11 & & & & & & & & & & & 0.2 & 0.0 & \\
\hline & & & ap23a12 & 0.1 & & & & & & & & & & & 0.0 & 0.0 \\
\hline & & & ap23a13 & & & & & & & & & & & 0.5 & 0.0 & 0.0 \\
\hline \multirow{7}{*}{ KRN-12-03 } & syenite & 1 & ap23a14 & & & & & & & & & & & 0.4 & 0.0 & 0.1 \\
\hline & & 1 & ap23a24 & & 0.0 & & & & & & & & & & & 0.0 \\
\hline & & 1 & ap23a25 & & & & & & & & & & & & & 0.0 \\
\hline & & 2 & ap23a27 & & & & & & & & & & & 0.2 & 0.2 & \\
\hline & & 2 & ap23a28 & 0.3 & 0.1 & 0.4 & 0.1 & 1.1 & 0.3 & 6.7 & & & & 1.1 & 4.4 & 2.6 \\
\hline & & 3 & ap23a29 & & & 0.0 & & & & & & & & & 0.0 & 0.0 \\
\hline & & 3 & ap23a30 & & 0.0 & & & 0.0 & & & & & & & 0.0 & 0.0 \\
\hline \multirow[t]{2}{*}{ KRN-12-05 } & granite & 1 & ap23a31 & & & & & & & & & & & & 0.1 & \\
\hline & & 2 & ap23a40 & & & & & & & & & & & 0.3 & 0.0 & \\
\hline \multirow[t]{2}{*}{ TUV-10-03 } & rhyodacite & 1 & ap23a61 & & & & & & & & & & & 0.9 & 0.0 & 0.0 \\
\hline & host & 2 & ap23a63 & & & & & & & 0.0 & & & & 0.4 & 0.1 & \\
\hline
\end{tabular}


Appendix V. (Cont.)

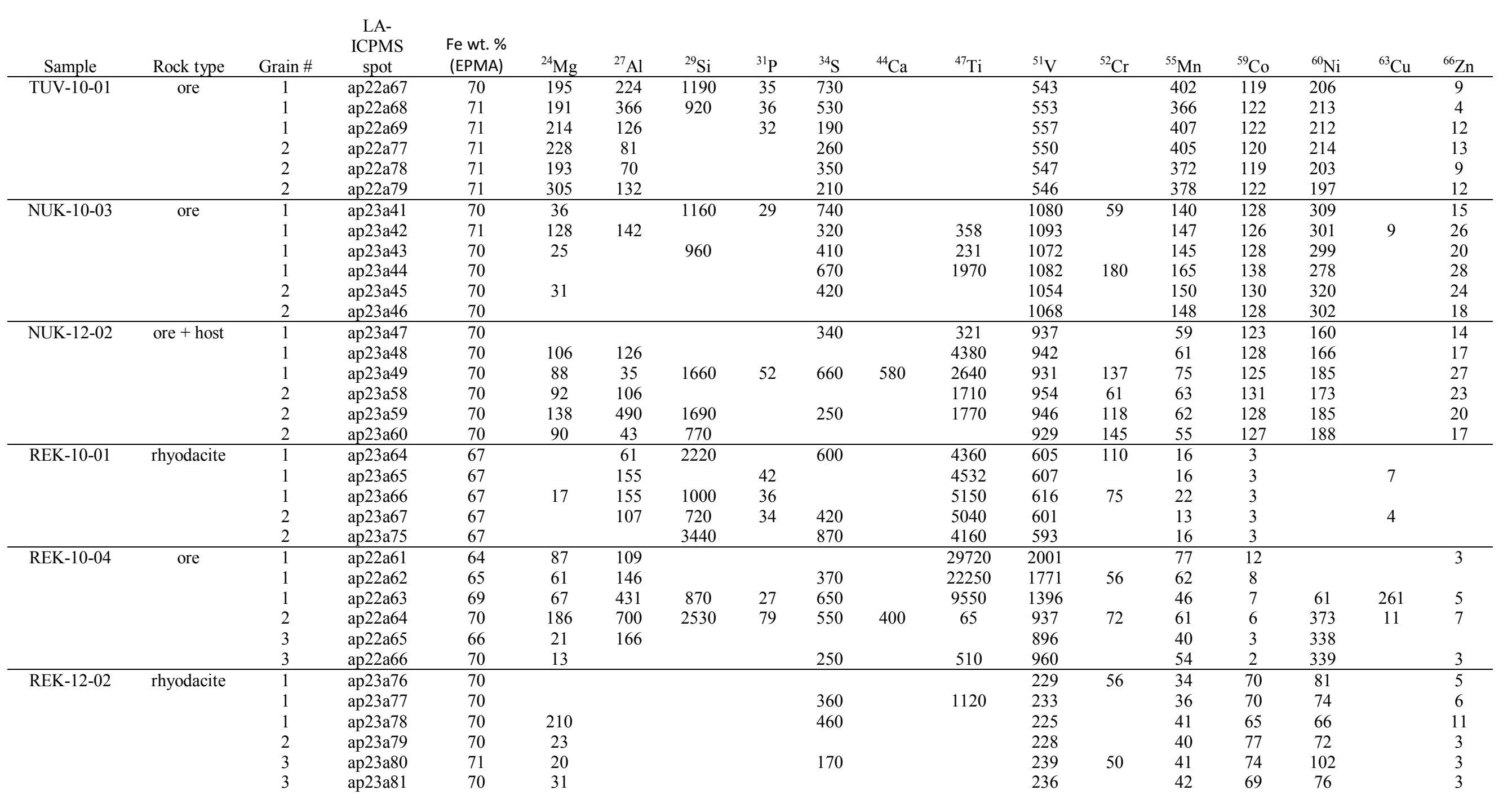


Appendix V. (Cont.)

\begin{tabular}{|c|c|c|c|c|c|c|c|c|c|c|c|c|c|c|c|c|c|}
\hline Sample & Rock type & Grain \# & $\begin{array}{c}\text { LA-ICPMS } \\
\text { spot }\end{array}$ & ${ }^{71} \mathrm{Ga}$ & ${ }^{75} \mathrm{As}$ & ${ }^{88} \mathrm{Sr}$ & ${ }^{89} \mathrm{Y}$ & ${ }^{93} \mathrm{Nb}$ & ${ }^{118} \mathrm{Sn}$ & ${ }^{139} \mathrm{La}$ & ${ }^{140} \mathrm{Ce}$ & ${ }^{141} \mathrm{Pr}$ & ${ }^{146} \mathrm{Nd}$ & ${ }^{147} \mathrm{Sm}$ & ${ }^{153} \mathrm{Eu}$ & ${ }^{157} \mathrm{Gd}$ & ${ }^{159} \mathrm{~Tb}$ \\
\hline \multirow[t]{6}{*}{ TUV-10-01 } & ore & 1 & ap22a67 & 27.2 & & & & & & 0.1 & 0.0 & 0.0 & & 0.1 & & & \\
\hline & & 1 & ap22a68 & 27.7 & & & 0.2 & & & 0.2 & 0.2 & 0.3 & & & & & \\
\hline & & 1 & ap22a69 & 28.1 & 1.4 & 2.0 & & & & & 0.3 & & & & & & \\
\hline & & 2 & ap22a77 & 28.5 & & 0.5 & & & & 0.3 & 1.0 & & & & & & \\
\hline & & 2 & ap22a78 & 27.0 & & 0.5 & 0.2 & & & & & 0.1 & 1.6 & & & & \\
\hline & & 2 & ap22a79 & 28.6 & & 2.0 & 0.1 & & & 0.2 & 0.3 & & & & & & \\
\hline \multirow[t]{6}{*}{ NUK-10-03 } & ore & 1 & ap23a41 & 20.5 & & & 0.3 & & & 0.1 & 0.4 & & 0.3 & & & & \\
\hline & & 1 & ap23a42 & 22.8 & 1.0 & 0.4 & 1.9 & & 0.9 & 1.5 & 3.9 & 0.4 & 1.9 & 0.3 & & & \\
\hline & & 1 & ap23a43 & 21.2 & & & 0.1 & 0.2 & & 0.1 & 0.3 & & & & & & \\
\hline & & 1 & ap23a44 & 28.2 & & & 1.9 & 0.4 & 2.0 & 95.0 & 137.0 & 7.4 & 18.1 & 2.1 & & & 0.2 \\
\hline & & 2 & ap23a45 & 21.8 & & 1.3 & & & & 0.3 & 0.2 & & & & & & \\
\hline & & 2 & ap23a46 & 21.6 & & & & & & 0.3 & 0.4 & 0.1 & & & & & \\
\hline \multirow{6}{*}{ NUK-12-02 } & ore + host & 1 & ap23a47 & 5.9 & & 2.5 & 0.4 & 0.3 & & 0.9 & 1.9 & 0.4 & 0.5 & & & & \\
\hline & & 1 & ap23a48 & 6.0 & 1.3 & 1.7 & 0.5 & 4.9 & & 0.6 & 1.1 & 0.1 & 0.6 & & & & \\
\hline & & 1 & ap23a49 & 6.0 & 1.7 & 5.4 & 0.8 & 2.9 & & 2.3 & 2.9 & 0.3 & 1.3 & 0.2 & 0.1 & & 0.0 \\
\hline & & 2 & ap23a58 & 6.3 & 1.3 & 5.4 & 0.9 & 1.7 & & 3.0 & 6.5 & 0.4 & 1.8 & 0.3 & & & \\
\hline & & 2 & ap23a59 & 6.1 & 1.1 & 3.9 & 0.8 & 2.2 & & 2.3 & 4.4 & 0.5 & 1.0 & & & & 0.1 \\
\hline & & 2 & ap23a60 & 5.2 & & 5.1 & 0.3 & & & 1.2 & 2.4 & 0.3 & 1.1 & 0.2 & & & 0.0 \\
\hline \multirow[t]{5}{*}{ REK-10-01 } & rhyodacite & 1 & ap23a64 & 4.2 & 15.0 & & 1.0 & 0.8 & 2.5 & 4.1 & 5.4 & 0.4 & 0.9 & & & & \\
\hline & & 1 & ap23a65 & 3.6 & 15.9 & 1.0 & 1.9 & 1.1 & 2.1 & 5.2 & 5.4 & 0.5 & 1.3 & 0.2 & & & \\
\hline & & 1 & ap23a66 & 3.3 & 36.9 & 1.0 & 2.2 & 2.2 & 1.8 & 5.5 & 6.2 & 0.5 & 1.6 & 0.4 & 0.2 & 0.7 & 0.1 \\
\hline & & 2 & ap23a67 & 3.6 & 2.9 & & 0.3 & 0.4 & 1.7 & 4.8 & 4.3 & 0.6 & 1.0 & 0.2 & & & \\
\hline & & 2 & ap23a75 & 3.3 & 27.3 & 1.2 & 1.5 & 1.6 & 2.6 & 3.3 & 4.5 & 0.6 & 0.7 & & & & 0.1 \\
\hline \multirow[t]{6}{*}{ REK-10-04 } & ore & 1 & ap22a61 & 9.6 & & & 0.1 & 0.5 & 6.0 & 0.3 & 0.3 & & & 0.1 & & & \\
\hline & & 1 & ap22a62 & 10.4 & & 1.7 & 0.2 & 0.8 & 4.8 & 0.3 & 0.7 & 0.1 & 0.6 & & & & \\
\hline & & 1 & ap22a63 & 16.7 & 3.2 & 2.2 & 1.2 & 1.3 & 3.4 & 2.2 & 3.8 & 0.4 & 1.4 & 0.2 & & & \\
\hline & & 2 & ap22a64 & 30.1 & 2.2 & 4.2 & 2.4 & & & 17.0 & 21.8 & 2.3 & 5.7 & 1.2 & 0.3 & 0.7 & 0.1 \\
\hline & & 3 & ap22a65 & 23.5 & & & & & & 0.1 & 0.5 & & & & & & \\
\hline & & 3 & ap22a66 & 27.3 & & & 0.5 & 0.2 & & 0.6 & 1.4 & 0.2 & 0.6 & & & & \\
\hline \multirow[t]{6}{*}{ REK-12-02 } & rhyodacite & 1 & ap23a76 & 1.7 & & & & & & & & & & & & & \\
\hline & & 1 & ap23a77 & 1.7 & & & & 1.0 & & & & & 0.2 & & & & \\
\hline & & 1 & ap23a78 & 1.5 & & & & & & 0.2 & 0.1 & & & & & & \\
\hline & & 2 & ap23a79 & 1.7 & & & & & & & 0.1 & & & & & & \\
\hline & & 3 & ap23a 80 & 1.8 & & & & & & & & & & & & & \\
\hline & & 3 & ap23a81 & 2.1 & & & & & & & & & & & & & \\
\hline
\end{tabular}


Appendix V. (Cont.)

LA-

ICPMS

\begin{tabular}{|c|c|c|c|c|c|c|c|c|c|c|c|c|c|c|c|c|}
\hline Sample & Rock type & Grain \# & spot & ${ }^{163}$ Dy & ${ }^{165} \mathrm{Ho}$ & ${ }^{166} \mathrm{Er}$ & ${ }^{169} \mathrm{Tm}$ & ${ }^{172} \mathrm{Yb}$ & ${ }^{175} \mathrm{Lu}$ & ${ }^{178} \mathrm{Hf}$ & ${ }^{181} \mathrm{Ta}$ & ${ }^{197} \mathrm{Au}$ & ${ }^{205} \mathrm{Tl}$ & ${ }^{208} \mathrm{~Pb}$ & ${ }^{232} \mathrm{Th}$ & ${ }^{238} \mathrm{U}$ \\
\hline \multirow[t]{6}{*}{ TUV-10-01 } & ore & 1 & ap22a67 & 0.0 & & & & 0.0 & & & & & & & 0.0 & 0.0 \\
\hline & & 1 & ap22a68 & & & & & & & & & & & 0.1 & 0.1 & 0.1 \\
\hline & & 1 & ap22a69 & & 0.0 & & & & & 0.0 & & & & 0.3 & 0.0 & 0.0 \\
\hline & & 2 & ap22a77 & & & & & & & & & & & 0.3 & 0.1 & 0.0 \\
\hline & & 2 & ap22a78 & & & & & 0.0 & & & & & & 0.3 & 0.1 & 0.0 \\
\hline & & 2 & ap22a79 & & & & & & & & & & & 0.1 & 0.3 & 0.1 \\
\hline \multirow[t]{6}{*}{ NUK-10-03 } & ore & 1 & ap23a41 & & & & 0.0 & & & & & & & 0.1 & 0.1 & \\
\hline & & 1 & ap23a42 & 0.2 & & 0.3 & & 0.3 & & & & & & 0.4 & 0.4 & 0.2 \\
\hline & & 1 & ap $23 a 43$ & & & & & & & & & & & 0.7 & 0.2 & 0.1 \\
\hline & & 1 & ap23a44 & 0.5 & 0.1 & & & & & & & & & 2.2 & 7.2 & 1.2 \\
\hline & & 2 & ap23a45 & & & & & & & & & & & 0.1 & 0.1 & 0.0 \\
\hline & & 2 & ap23a46 & & & & & & & & & & 0.0 & 0.1 & 0.0 & 0.0 \\
\hline \multirow{6}{*}{ NUK-12-02 } & ore + host & 1 & ap23a47 & 0.3 & 0.0 & & & 0.0 & & & & & & 1.1 & 0.1 & 0.2 \\
\hline & & 1 & ap23a48 & & & & & & & & 0.2 & & 0.0 & 0.7 & 0.3 & 1.9 \\
\hline & & 1 & ap23a49 & 0.2 & 0.0 & 0.1 & & & & & 0.2 & & & 3.6 & 0.6 & 1.0 \\
\hline & & 2 & ap23a58 & 0.3 & 0.0 & & & & & 0.0 & 0.1 & & & 4.2 & 0.4 & 0.8 \\
\hline & & 2 & ap23a59 & 0.3 & & 0.1 & & & & & 0.1 & & & 3.1 & 0.2 & 0.5 \\
\hline & & 2 & ap23a60 & & 0.0 & 0.1 & & & & 0.0 & & & & 1.3 & 0.3 & 0.2 \\
\hline \multirow[t]{5}{*}{ REK-10-01 } & rhyodacite & 1 & ap23a64 & & 0.1 & & & & & 0.1 & & & & 1.7 & 0.4 & 8.4 \\
\hline & & 1 & ap23a65 & 0.3 & 0.1 & 0.2 & 0.0 & 0.3 & & 2.7 & 0.3 & & 0.0 & 3.2 & 0.8 & 11.6 \\
\hline & & 1 & ap23a66 & 1.0 & 0.1 & 0.4 & & 0.2 & & 0.0 & 0.4 & & & 4.1 & 1.5 & 50.9 \\
\hline & & 2 & ap23a67 & & & 0.0 & & & & 0.1 & 0.1 & & & 1.0 & 0.2 & 1.0 \\
\hline & & 2 & ap23a75 & 0.4 & 0.1 & & & & & 1.6 & & & & 3.3 & 0.6 & 14.1 \\
\hline \multirow[t]{6}{*}{ REK-10-04 } & ore & 1 & ap22a61 & & & & & & & & 0.0 & 0.0 & & & 0.1 & 0.8 \\
\hline & & 1 & ap22a62 & & & 0.0 & & & & 0.1 & & & & 0.1 & 0.1 & 0.5 \\
\hline & & 1 & ap22a63 & 0.2 & & 0.1 & & 0.2 & 0.0 & & 0.1 & & & 2.0 & 1.4 & 5.1 \\
\hline & & 2 & ap22a64 & 0.4 & 0.1 & 0.2 & & 0.1 & & & & & & 2.6 & 2.9 & 1.3 \\
\hline & & 3 & ap22a65 & & & & & & 0.0 & & & & 0.0 & 0.1 & 0.0 & 0.1 \\
\hline & & 3 & ap22a66 & 0.1 & 0.0 & 0.1 & & & & & & & & 0.7 & 0.1 & 1.6 \\
\hline \multirow[t]{6}{*}{ REK-12-02 } & rhyodacite & 1 & ap23a76 & & & & & 0.0 & & & & & & 0.1 & & 0.0 \\
\hline & & 1 & ap23a77 & & & & & & & & & & & 0.3 & 0.0 & 0.1 \\
\hline & & 1 & ap23a78 & & & & & 0.0 & & & & & & 0.4 & 0.0 & 0.0 \\
\hline & & 2 & ap23a79 & & 0.0 & & & & & & & & & & & \\
\hline & & 3 & ap23a80 & & & 0.0 & & & & & & & & & & \\
\hline & & 3 & ap23a81 & & & 0.0 & & & & & & & & & & 0.0 \\
\hline
\end{tabular}


Appendix V. (Cont.)

\begin{tabular}{|c|c|c|c|c|c|c|c|c|c|c|c|c|c|c|}
\hline Sample & rock type & Grain \# & $\begin{array}{c}\text { LA-ICPMS } \\
\text { spot }\end{array}$ & $\begin{array}{l}\text { Fe wt. \% } \\
\text { (EPMA) } \\
\end{array}$ & ${ }^{24} \mathrm{Mg}$ & ${ }^{27} \mathrm{Al}$ & ${ }^{29} \mathrm{Si}$ & ${ }^{31} \mathrm{P}$ & ${ }^{34} \mathrm{~S}$ & ${ }^{44} \mathrm{Ca}$ & ${ }^{47} \mathrm{Ti}$ & ${ }^{51} \mathrm{~V}$ & ${ }^{52} \mathrm{Cr}$ & ${ }^{55} \mathrm{Mn}$ \\
\hline \multirow{9}{*}{ ELL-14-02 } & & 1 & no05b10 & 61 & 3310 & 6370 & 4100 & & & & 62100 & 3050 & 775 & 4690 \\
\hline & & 2 & no05b12 & 66 & 2410 & 5210 & & 142 & 680 & & 59800 & 3122 & 842 & 3570 \\
\hline & & 2 & no05b13 & 66 & 4690 & 5420 & & 1600 & & & 70900 & 2990 & 590 & 4210 \\
\hline & & 2 & no05b14 & 65 & 3430 & 4840 & 6060 & & 1370 & & 64600 & 2951 & 748 & 5040 \\
\hline & & 3 & no05b17 & 64 & 2147 & 9340 & & 1860 & 2500 & & 57300 & 3160 & 837 & 3786 \\
\hline & & 4 & no05b18 & 64 & 2516 & 1027 & & & & & 66100 & 3241 & 772 & 3915 \\
\hline & & 4 & no05b19 & 59 & 2220 & 8870 & & & 390 & & 57400 & 2926 & 739 & 3484 \\
\hline & & 4 & no05b20 & 62 & 2089 & 8980 & & & & & 64000 & 3010 & 718 & 3839 \\
\hline & & 4 & no05b21 & 64 & 2030 & 5270 & & 470 & & & 70600 & 2616 & 646 & 4372 \\
\hline \multirow{11}{*}{ ELL-14-04 } & & 1 & no05d07 & 69 & 438 & 1526 & 3600 & 253 & & & 285 & 1944 & & 23.7 \\
\hline & & 2 & no05d08 & 70 & 8580 & 1808 & & & & & 234 & 1934 & & 321 \\
\hline & & 2 & no05d09 & 70 & 8040 & 1572 & & 100 & & & 284 & 1947 & & 385.5 \\
\hline & & 2 & no05d10 & 70 & 7960 & 1601 & & & & & 278 & 1871 & & 351 \\
\hline & & 3 & no05d11 & 70 & 7250 & 1638 & 3060 & 106 & 1260 & & 239 & 1873 & 100 & 310 \\
\hline & & 3 & no05d12 & 70 & 7770 & 1737 & & 137 & & & 349 & 1967 & & 354 \\
\hline & & 3 & no05d13 & 70 & 7790 & 1626 & & 124 & & & 307 & 1961 & & 417 \\
\hline & & 3 & no05d14 & 70 & 7070 & 1613 & & 100 & & & 224 & 1804 & & 306 \\
\hline & & 4 & no05d17 & 70 & 8170 & 1645 & & & & & 301 & 1810 & & 234.5 \\
\hline & & 4 & no05d18 & 69 & 7860 & 1611 & & & & & 209 & 1771 & & 333.5 \\
\hline & & 4 & no05d19 & 70 & 11440 & 1733 & 6440 & 182 & & & 366 & 1760 & & 313 \\
\hline
\end{tabular}


Appendix V. (Cont.)

\begin{tabular}{|c|c|c|c|c|c|c|c|c|c|c|c|c|c|c|}
\hline Sample & rock type & Grain \# & $\begin{array}{c}\text { LA-ICPMS } \\
\text { spot }\end{array}$ & ${ }^{59} \mathrm{Co}$ & ${ }^{60} \mathrm{Ni}$ & ${ }^{63} \mathrm{Cu}$ & ${ }^{66} \mathrm{Zn}$ & ${ }^{71} \mathrm{Ga}$ & ${ }^{72} \mathrm{Ge}$ & ${ }^{75} \mathrm{As}$ & ${ }^{88} \mathrm{Sr}$ & ${ }^{89} \mathrm{Y}$ & ${ }^{93} \mathrm{Nb}$ & ${ }^{95} \mathrm{Mo}$ \\
\hline \multirow{15}{*}{ ELL-14-02 } & andesite host & 1 & no05b09 & 127.7 & 223 & 23.5 & 847 & 52.3 & & & & 1.72 & 14.2 & \\
\hline & & 1 & no05b10 & 123.5 & 241 & 25.5 & 2210 & 48.7 & & & & 1.23 & 13.59 & \\
\hline & & 1 & no05b11 & 123 & 305 & 31.4 & 1251 & 53.5 & & & & 1.22 & 15.1 & \\
\hline & & 2 & no05b12 & 121.5 & 281 & 35.8 & 1212 & 50.6 & & & & 1.21 & 11.99 & \\
\hline & & 2 & no05b13 & 128.4 & 274 & & 1103 & 51.5 & & & 3.1 & 2.33 & 17 & \\
\hline & & 2 & no05b14 & 124.4 & 196 & 96.1 & 1691 & 49.6 & & & 1.03 & 1.26 & 24.5 & \\
\hline & & 3 & no05b15 & 107.2 & 152 & 24.2 & 844 & 45.2 & & & & 0.98 & 19.79 & \\
\hline & & 3 & no05b16 & 114.7 & 155 & 23.9 & 1164 & 44.6 & & & 0.69 & 1.44 & 31.1 & \\
\hline & & 3 & no05b17 & 127.4 & 226 & 24 & 3060 & 57 & & & 3.29 & 4.2 & 8.9 & \\
\hline & & 4 & no05b18 & 131.1 & 188 & 19.6 & 1659 & 51.3 & & & & 1.65 & 11.44 & \\
\hline & & 4 & no05b19 & 118.9 & 176 & 23.1 & 2780 & 50.7 & & & & 1.05 & 9.57 & \\
\hline & & 4 & no 05 b20 & 126.2 & 174 & 17.8 & 1666 & 46.8 & & & & 1.55 & 10.7 & \\
\hline & & 4 & no05b21 & 101.4 & 132 & 17.6 & 1468 & 45.2 & & & 1.23 & 1.53 & 30.9 & \\
\hline & & 5 & no 05 b 22 & 101.9 & 139 & 16.9 & 1850 & 44.3 & & & & 1.4 & 37 & \\
\hline & & 5 & no05b23 & 101.4 & 140 & 18.3 & 1967 & 44.6 & & & 1.66 & 1.32 & 32.7 & \\
\hline \multirow[t]{14}{*}{ ELL-14-04 } & vuggy ore & 1 & no05d05 & 21.2 & 572 & & & 6.75 & & 27.3 & & & & \\
\hline & & 1 & no05d06 & 23.1 & 427 & & & 6.45 & & & & & & \\
\hline & & 1 & no05d07 & 16.3 & 430 & & & 6.55 & & 17.5 & & & 0.52 & 3.6 \\
\hline & & 2 & no05d08 & 147.3 & 469 & & 56 & 6.22 & & & 1.35 & & 0.81 & \\
\hline & & 2 & no05d09 & 149.4 & 414 & & 53.5 & 6.04 & & & & & & \\
\hline & & 2 & no05d 10 & 146.2 & 435 & & 37.3 & 6.12 & & & & & 0.007 & \\
\hline & & 3 & no05d 11 & 143.7 & 409 & & 46.5 & 5.86 & & & & & 0.44 & \\
\hline & & 3 & no05d12 & 150.3 & 443 & & 62.5 & 5.99 & & & & & 1.58 & \\
\hline & & 3 & no05d 13 & 146.7 & 456 & & 57.8 & 5.65 & & & & & 0.42 & \\
\hline & & 3 & no05d14 & 147.1 & 381 & & 50 & 5.49 & & & & & 0.55 & \\
\hline & & 4 & no05d 17 & 144 & 418 & & 60.5 & 7.1 & & & & & 0.19 & \\
\hline & & 4 & no05d 18 & 144.3 & 463 & & 53.8 & 6.11 & & & & & 0.27 & \\
\hline & & 4 & no05d19 & 143 & 424 & & 42.5 & 7.84 & & & 1.52 & 1.99 & 8.27 & \\
\hline & & 4 & no0 $05 \mathrm{~d} 20$ & 144.9 & 397 & & 46.4 & 6.23 & & & 1.9 & 0.23 & 3.92 & \\
\hline
\end{tabular}


Appendix V. (Cont.)

LA-

ICPMS

\begin{tabular}{|c|c|c|c|c|c|c|c|c|c|c|c|c|c|c|c|}
\hline Sample & rock type & Grain \# & spot & ${ }^{107} \mathrm{Ag}$ & ${ }^{115} \mathrm{In}$ & ${ }^{118} \mathrm{Sn}$ & ${ }^{121} \mathrm{Sb}$ & ${ }^{138} \mathrm{Ba}$ & ${ }^{140} \mathrm{Ce}$ & ${ }^{181} \mathrm{Ta}$ & ${ }^{184} \mathrm{~W}$ & ${ }^{197} \mathrm{Au}$ & ${ }^{205} \mathrm{Tl}$ & ${ }^{208} \mathrm{~Pb}$ & ${ }^{232} \mathrm{Th}$ \\
\hline \multirow{16}{*}{ ELL-14-02 } & andesite & 1 & no05b09 & & & 6.93 & & & 2.57 & 0.46 & & & & & \\
\hline & host & 1 & no05b10 & & & 6.8 & & 13.2 & 7.22 & 0.39 & 1.87 & & & 1.79 & 0.51 \\
\hline & & & & & 0.20 & & & & & & & & & & \\
\hline & & 1 & no05b11 & & 1 & 10.2 & & & 3.24 & 0.72 & 0.125 & & 0.015 & & 0.136 \\
\hline & & 2 & no05b12 & 0.013 & & 10.4 & & & 2.69 & 0.32 & 0.024 & & & 0.48 & 0.044 \\
\hline & & 2 & no05b13 & & & 17.8 & & 20.1 & 9.6 & & 0.32 & & & 1 & 0.061 \\
\hline & & 2 & no05b14 & & & 6.34 & & 24.8 & 10 & 0.6 & 4.39 & & 0.02 & 3.48 & 1.38 \\
\hline & & 3 & no05b15 & & & 5.95 & & & 3.01 & 0.5 & & & & 0.52 & \\
\hline & & 3 & no05b16 & & & 6.77 & & 12.4 & 16.8 & 0.84 & 2.6 & & & 3.06 & 0.93 \\
\hline & & 3 & no05b17 & & & & & & 11.9 & 0.79 & & & & & 0.056 \\
\hline & & 4 & no05b18 & & & 6.51 & & & 1.82 & 0.6 & & & & & \\
\hline & & 4 & no05b19 & & & 7.8 & & & 3.08 & 0.39 & 0.121 & & & & 0.178 \\
\hline & & 4 & no05b20 & & & 7.5 & & & 0.72 & 0.33 & & & & & \\
\hline & & 4 & no05b21 & & & 8.9 & & 2.35 & 8.3 & 0.71 & 0.23 & & 0.016 & & 0.4 \\
\hline & & 5 & no05b22 & & & 6.9 & & 1.12 & 8.51 & 0.93 & 0.24 & & & 1.18 & 0.4 \\
\hline & & 5 & no05b23 & & & & & 11.6 & 10.2 & & 0.57 & & 0.008 & 1.89 & 0.84 \\
\hline \multirow[t]{14}{*}{ ELL-14-04 } & vuggy & 1 & no05d05 & & & 17.7 & & 5.1 & 0.61 & & 4.02 & & & 0.57 & 0.018 \\
\hline & ore & 1 & no05d06 & & & 14.4 & & 2.77 & 0.082 & & & & 0.009 & & \\
\hline & & 1 & no05d07 & & & 15.5 & & 2.32 & 0.56 & & 4.2 & & & & 0.026 \\
\hline & & 2 & no05d08 & & & 15.2 & & 2.01 & 1.28 & & & & & & 0.83 \\
\hline & & 2 & no05d09 & & & 11.6 & & & & & & & & & 0.165 \\
\hline & & 2 & no05d 10 & & & 14.8 & & & & & 0.07 & & & & 0.051 \\
\hline & & 3 & no05d11 & & & 12.4 & & & 0.151 & & & & & & \\
\hline & & 3 & no05d12 & & & 13.8 & & & 0.64 & & & & & & 0.49 \\
\hline & & 3 & no05d13 & & & 14 & & & & & & & 0.022 & & 0.054 \\
\hline & & 3 & no05d14 & & & 16.4 & & & 0.36 & & & & & & 0.03 \\
\hline & & 4 & no05d 17 & & & 13 & & & & & & & & & 0.015 \\
\hline & & 4 & no05d18 & & & 15.6 & & & & & & & & & 0.0059 \\
\hline & & 4 & no05d19 & & & 15.9 & & 3.03 & 7.85 & 0.7 & & & 0.006 & & 1.78 \\
\hline & & 4 & no05d20 & & & 13.3 & & 1.86 & 3.41 & 0.32 & & & & 0.56 & 0.57 \\
\hline
\end{tabular}


Appendix V. (Cont.)

LA-

ICPMS Fe wt. \%

\begin{tabular}{|c|c|c|c|c|c|c|c|c|c|c|c|c|c|c|}
\hline Sample & rock type & Grain \# & $\begin{array}{c}\text { ICPMS } \\
\text { spot }\end{array}$ & $\begin{array}{l}\text { Fe wt. \% } \\
\text { (EPMA) }\end{array}$ & ${ }^{24} \mathrm{Mg}$ & ${ }^{27} \mathrm{Al}$ & ${ }^{29} \mathrm{Si}$ & ${ }^{31} \mathrm{P}$ & ${ }^{34} \mathrm{~S}$ & ${ }^{44} \mathrm{Ca}$ & ${ }^{47} \mathrm{Ti}$ & ${ }^{51} \mathrm{~V}$ & ${ }^{52} \mathrm{Cr}$ & ${ }^{55} \mathrm{Mn}$ \\
\hline \multirow[t]{18}{*}{ ELL-14-05 } & vesicular ore & 1 & no05c08 & 70 & 13740 & 1796 & 9700 & 124 & 410 & & & 1002 & & 481 \\
\hline & & 1 & no05c09 & 68 & 14420 & 2209 & 13500 & & & 2520 & 215 & 1045 & & 532 \\
\hline & & 1 & no05c10 & 69 & 12900 & 1715 & 9300 & & & 2070 & 239 & 1030 & & 485 \\
\hline & & 1 & no05c11 & 70 & 9110 & 1099 & & & & & 162 & 960 & & 403 \\
\hline & & 2 & no05c12 & 70 & 9580 & 2240 & 8000 & 365 & 350 & & & 999 & & 245 \\
\hline & & 2 & no05c13 & 68 & 9640 & 1470 & & & & & & 1068 & & 388 \\
\hline & & 2 & no05c14 & 69 & 9060 & 1586 & 7560 & 199 & 700 & & & 1045 & 55 & 433 \\
\hline & & 2 & no05c15 & 69 & 10970 & 1474 & 5720 & & & & & 1059 & & 470 \\
\hline & & 3 & no05c16 & 69 & 8980 & 1326 & 4000 & & & & 149 & 878 & & 407 \\
\hline & & 3 & no05c17 & 68 & 7800 & 1337 & 3920 & 162 & & & 238 & 898 & & 288 \\
\hline & & 3 & no05c18 & 68 & 8700 & 1478 & 4400 & & & & 113 & 873 & & 325 \\
\hline & & 4 & no05c22 & 68 & 12400 & 1771 & 11700 & & & 2940 & 373 & 1016 & & 494 \\
\hline & & 4 & no05c23 & 69 & 9270 & 1460 & 7710 & & 420 & & 424 & 939 & & 462 \\
\hline & & 4 & no05c24 & 69 & 10170 & 1343 & & & & & 580 & 1032 & & 485 \\
\hline & & 4 & no05c25 & 69 & 8970 & 1092 & 4170 & & & & 332 & 1056 & & 463 \\
\hline & & 5 & no05c26 & 69 & 5720 & 891 & 3410 & 170 & & & 204 & 1032 & 54 & 307 \\
\hline & & 5 & no05c27 & 69 & 6450 & 746 & & & & & & 1000 & & 304.2 \\
\hline & & 5 & no05c28 & 68 & 5390 & 838 & & 182 & & & & 996 & & 267 \\
\hline \multirow[t]{10}{*}{ ELL-14-06 } & vein ore & 1 & no05a06 & 67 & 3400 & 167 & & 297 & 720 & & 350 & 614 & 65 & 261 \\
\hline & & 1 & no05a07 & 67 & 2640 & 206 & 4110 & 843 & 320 & & 270 & 630 & & 209 \\
\hline & & 1 & no05a08 & 68 & 5420 & 106 & 2720 & 417 & 650 & & & 602 & & 260.6 \\
\hline & & 1 & no05a09 & 68 & 7610 & 77 & 6750 & 318 & & 1730 & 460 & 553 & & 362 \\
\hline & & 1 & no05a10 & 69 & 8840 & & 6390 & 171 & 640 & 1980 & & 561 & 132 & 406.7 \\
\hline & & 1 & no05a11 & 68 & 6150 & & & 132 & & & & 578 & & 311.5 \\
\hline & & 1 & no05a12 & 69 & 7220 & & 6470 & 330 & 780 & 1780 & & 586 & 57 & 340 \\
\hline & & 1 & no05a13 & 68 & 5820 & 79 & 4910 & 253 & 680 & & & 638 & & 315.8 \\
\hline & & 1 & no05a14 & 67 & 422 & 83 & 2120 & 96 & 1380 & & 460 & 774 & & 39.3 \\
\hline & & 1 & no05a 15 & 67 & 4040 & & & 295 & 1140 & & & 666 & 54 & 304.3 \\
\hline
\end{tabular}


Appendix V. (Cont.)

\begin{tabular}{|c|c|c|c|c|c|c|c|c|c|c|c|c|c|c|}
\hline Sample & rock type & Grain \# & $\begin{array}{l}\text { LA-ICP } \\
\text {-MS spot }\end{array}$ & ${ }^{59} \mathrm{Co}$ & ${ }^{60} \mathrm{Ni}$ & ${ }^{63} \mathrm{Cu}$ & ${ }^{66} \mathrm{Zn}$ & ${ }^{71} \mathrm{Ga}$ & ${ }^{72} \mathrm{Ge}$ & ${ }^{75} \mathrm{As}$ & ${ }^{88} \mathrm{Sr}$ & ${ }^{89} \mathrm{Y}$ & ${ }^{93} \mathrm{Nb}$ & ${ }^{95} \mathrm{Mo}$ \\
\hline \multirow{18}{*}{ ELL-14-05 } & vesicular ore & 1 & no05c08 & 176 & 426 & & & 1.7 & & & 1.4 & 1.2 & 3.6 & \\
\hline & & 1 & no05c09 & 162 & 416 & & 63 & 2.7 & & & 2.9 & 1.6 & 3.7 & \\
\hline & & 1 & no05c10 & 163 & 446 & & 52.6 & 2.3 & & & 1.6 & 1.2 & 3.4 & \\
\hline & & 1 & no05c11 & 160 & 483 & & 36.8 & 1.9 & & & & & 0.02 & \\
\hline & & 2 & no05c12 & 159 & 447 & 39 & 38.9 & 1.7 & & & 2.4 & & 1.9 & 8.5 \\
\hline & & 2 & no05c13 & 168 & 462 & & 58 & 3.4 & & & & 0.7 & 2.1 & \\
\hline & & 2 & no05c14 & 163 & 441 & 23 & 67 & 3.2 & & & 2.3 & 2.8 & 3.2 & \\
\hline & & 2 & no05c15 & 149 & 419 & & 49.9 & 1.7 & & & & 0.46 & 1.6 & \\
\hline & & 3 & no05c16 & 141 & 408 & & 31.8 & 1.5 & & & & 0.47 & 1.6 & \\
\hline & & 3 & no05c17 & 153 & 414 & 31 & 40.1 & 1.7 & & & 1.7 & 0.69 & 2.8 & \\
\hline & & 3 & no05c18 & 149 & 459 & 14 & 34.5 & 2.1 & & & 1.2 & 0.93 & 1.9 & \\
\hline & & 4 & no05c22 & 133 & 400 & & 66 & 2.2 & & & 2.0 & 1.43 & 3.5 & \\
\hline & & 4 & no05c23 & 138 & 434 & & 65 & 1.7 & & & 1.2 & 0.94 & 3.5 & \\
\hline & & 4 & no05c24 & 129 & 409 & & & & & & & 0.52 & 2.1 & \\
\hline & & 4 & no05c 25 & 131 & 421 & & 55 & & & & & 0.53 & 1.1 & \\
\hline & & 5 & no05c26 & 155 & 467 & 14 & 39.2 & 1.4 & & & 1.8 & 0.42 & 1.1 & 10 \\
\hline & & 5 & no05c27 & 136 & 451 & & & 1.9 & & & & & 1.7 & \\
\hline & & 5 & no05c28 & 143 & 403 & 13 & & 1.7 & & & 1.9 & 0.55 & 2.2 & 9.8 \\
\hline \multirow[t]{10}{*}{ ELL-14-06 } & vein ore & 1 & no05a06 & 113 & 290 & 13 & 55 & & & & & 0.73 & 0.36 & \\
\hline & & 1 & no05a07 & 95 & 281 & & 54.8 & & & 11 & 1.9 & 6.2 & 10 & \\
\hline & & 1 & no05a08 & 107 & 291 & 15 & 38.9 & & & & & 0.6 & 1.54 & \\
\hline & & 1 & no05a09 & 122 & 256 & & 60.4 & 1.4 & & 31 & 4.3 & 9.96 & 21.2 & \\
\hline & & 1 & no05a 10 & 126 & 273 & & 52.3 & 0.9 & & 26 & 4.0 & 8.23 & 17.7 & \\
\hline & & 1 & no05a11 & 116 & 243 & & 47.7 & & & 8.3 & 1.1 & 1.37 & 3.85 & \\
\hline & & 1 & no05a 12 & 120 & 263 & & 58.7 & 1.26 & & 22 & 3.4 & 6.63 & 13.0 & \\
\hline & & 1 & no05a13 & 110 & 256 & & 54 & 0.66 & & 17 & 2.3 & 4.91 & 11.7 & \\
\hline & & 1 & no05a14 & 64 & 265 & & & & & & & 0.41 & 1.99 & \\
\hline & & 1 & no05a15 & 110 & 235 & & 47 & 0.56 & & & & 0.54 & 1.3 & \\
\hline
\end{tabular}


Appendix V. (Cont.)

LA-

\begin{tabular}{|c|c|c|c|c|c|c|c|c|c|c|c|c|c|c|c|}
\hline Sample & rock type & Grain \# & $\begin{array}{l}\text { LA- } \\
\text { ICPMS spot }\end{array}$ & ${ }^{107} \mathrm{Ag}$ & ${ }^{115} \mathrm{In}$ & ${ }^{118} \mathrm{Sn}$ & ${ }^{121} \mathrm{Sb}$ & ${ }^{138} \mathrm{Ba}$ & ${ }^{140} \mathrm{Ce}$ & ${ }^{181} \mathrm{Ta}$ & ${ }^{184} \mathrm{~W}$ & ${ }^{197} \mathrm{Au}$ & ${ }^{205} \mathrm{Tl}$ & ${ }^{208} \mathrm{~Pb}$ & ${ }^{232} \mathrm{Th}$ \\
\hline \multirow[t]{18}{*}{ ELL-14-05 } & vesicular & 1 & no05c08 & & & 15.9 & & 1.23 & 10.7 & 0.53 & & & & & 0.49 \\
\hline & ore & 1 & no05c09 & & & 13.7 & & 2.13 & 11.49 & & & & & & 1.25 \\
\hline & & 1 & no $05 \mathrm{c} 10$ & & & 14.4 & & 1.63 & 8.1 & & & & & 0.76 & 0.54 \\
\hline & & 1 & no05c11 & 0.1 & & 13.9 & & & & & & & 0.009 & & \\
\hline & & 2 & no05c12 & & & 13.9 & & 3.17 & 2.85 & & & & 0.061 & 4.6 & 1.39 \\
\hline & & 2 & no05c13 & & & 13.5 & & 2.67 & 3.36 & & & & & 2.02 & 1.45 \\
\hline & & 2 & no05c14 & & & 15.6 & & 1.99 & 56.2 & & & & & 3.84 & 8.3 \\
\hline & & 2 & no05c15 & & & 9.8 & & & 2.95 & & & & & & 0.134 \\
\hline & & 3 & no05c16 & & & 10 & & & 1.33 & & & & & & 0.048 \\
\hline & & 3 & no05c17 & & & 12.7 & & 3.95 & 3.56 & & & & & 2.55 & 1.29 \\
\hline & & 3 & no05c18 & & & 13.5 & & 1.83 & 3.81 & & & & & 0.93 & 1.06 \\
\hline & & 4 & no05c22 & & & 12.2 & & 1.55 & 9.8 & & & & & & 1.2 \\
\hline & & 4 & no05c23 & & & 12.4 & & 1.09 & 5.22 & & & & & & 0.92 \\
\hline & & 4 & no05c24 & 0.037 & & & 0.26 & & 4.72 & 0.07 & & & & 0.185 & 0.18 \\
\hline & & 4 & no05c25 & & & 9.8 & & & 1.93 & & & & & & \\
\hline & & 5 & no05c26 & & & 10.6 & & 3.93 & 2.88 & & & & & 8.9 & 0.5 \\
\hline & & 5 & no05c27 & & & 15.9 & & & 0.78 & & 0.16 & & 0.012 & 4.65 & 0.9 \\
\hline & & 5 & no $05 \mathrm{c} 28$ & & & 10.3 & & 2.74 & 3.04 & & & & & 5.8 & 1.34 \\
\hline \multirow[t]{10}{*}{ ELL-14-06 } & vein ore & 1 & no05a06 & & & 12.7 & & & 17.4 & & & & & & 0.034 \\
\hline & & 1 & no05a07 & & & 13.9 & & 2.58 & 24.2 & & 0.53 & & & 0.31 & 13 \\
\hline & & 1 & no05a08 & & & 13.3 & & 0.94 & 6.8 & & & & 0.007 & & 1.53 \\
\hline & & 1 & no05a09 & & 0.211 & 13.22 & 3.86 & 5.17 & 68.9 & 0.36 & 0.8 & & & & 35.7 \\
\hline & & 1 & no05a10 & & & 11.7 & 4 & 4.23 & 53.9 & 0.17 & 0.65 & & & & 29.8 \\
\hline & & 1 & no05a11 & & & 11.9 & & 1.55 & 13.7 & & 0.075 & & & & 6.74 \\
\hline & & 1 & no05a12 & & & 12.84 & & 3.42 & 55.2 & 0.27 & 0.48 & & & 0.197 & 22.14 \\
\hline & & 1 & no05a13 & & 0.17 & 13.11 & & 2.54 & 30.5 & 0.15 & 0.45 & & & & 15.6 \\
\hline & & 1 & no05a14 & & & 12.84 & & & 2.44 & & & & & & 0.292 \\
\hline & & 1 & no05a15 & & & 14.01 & & & 4.72 & & & & & & 0.157 \\
\hline
\end{tabular}


Appendix V. (Cont.)

\begin{tabular}{|c|c|c|c|c|c|c|c|c|c|c|c|c|c|c|}
\hline Sample & rock type & $\begin{array}{c}\text { Grain } \\
\#\end{array}$ & $\begin{array}{c}\text { LA-ICPMS } \\
\text { spot }\end{array}$ & $\begin{array}{l}\text { Fe wt. \% } \\
\text { (EPMA) }\end{array}$ & ${ }^{24} \mathrm{Mg}$ & ${ }^{27} \mathrm{Al}$ & ${ }^{29} \mathrm{Si}$ & ${ }^{31} \mathrm{P}$ & ${ }^{34} \mathrm{~S}$ & ${ }^{44} \mathrm{Ca}$ & ${ }^{47} \mathrm{Ti}$ & ${ }^{51} \mathrm{~V}$ & ${ }^{52} \mathrm{Cr}$ & ${ }^{55} \mathrm{Mn}$ \\
\hline \multirow[t]{10}{*}{ ELL-14-06 } & vein ore & 2 & no05a18 & 69 & 9200 & & 7490 & 85 & 280 & 2750 & 1290 & 538.4 & & 399.3 \\
\hline & & 2 & no05a19 & 69 & 8160 & 56 & 6790 & 327 & & 1570 & & 521 & & 348.4 \\
\hline & & 2 & no05a20 & 67 & 5940 & & 4800 & 220 & & & 280 & 545 & & 291 \\
\hline & & 2 & no05a21 & 69 & 4950 & 82 & 5950 & 404 & 730 & & & 555 & & 234 \\
\hline & & 2 & no05a22 & 67 & 2120 & 74 & 3300 & 500 & 970 & & & 541 & & 149 \\
\hline & & 3 & no05a 23 & 68 & 2265 & 156 & 3350 & 920 & 500 & 1130 & 930 & 570 & & 150.3 \\
\hline & & 3 & no05a24 & 69 & 5440 & & 2430 & 71 & & & 96 & 570 & & 313.3 \\
\hline & & 3 & no05a26 & 69 & 6700 & & 5770 & 570 & 650 & 1780 & & 550 & 54 & 303 \\
\hline & & 3 & no05a 27 & 68 & 1979 & 113 & & 1262 & 1230 & & & 571 & & 168.7 \\
\hline & & 3 & no05a 28 & 68 & 4820 & & & 830 & 800 & & & 557 & & 250.1 \\
\hline \multirow[t]{8}{*}{ LAS-14-07 } & pyroclastic & 1 & no05d 21 & 61 & 13430 & 13710 & & 2140 & 650 & 5500 & 79800 & 4683 & 747 & 4345 \\
\hline & dacite & 1 & no05d 22 & 61 & 13680 & 13350 & & 2940 & 770 & 5960 & 79100 & 4605 & 811 & 4304 \\
\hline & & 1 & $\operatorname{no} 05 \mathrm{~d} 23$ & 60 & 13450 & 13690 & & 500 & 910 & 1760 & 79000 & 4496 & 773 & 4174 \\
\hline & & 1 & no05d24 & 61 & 13790 & 13550 & & 291 & 640 & & 81600 & 4631 & 847 & 4309 \\
\hline & & 2 & no05d 27 & 57 & 15080 & 7650 & & & & & 11320 & 5250 & 795 & 3930 \\
\hline & & 3 & no05d 30 & 61 & 14780 & 10850 & & 70 & & & 77800 & 4820 & 771 & 3907 \\
\hline & & 4 & no0 $0 \mathrm{~d} 33$ & 61 & 15320 & 15000 & 9500 & & & & 75900 & 4080 & 916 & 3816 \\
\hline & & 4 & no05d34 & 61 & 15990 & 12990 & & & 550 & & 77600 & 4030 & 914 & 3955 \\
\hline
\end{tabular}


Appendix V. (Cont.)

\begin{tabular}{|c|c|c|c|c|c|c|c|c|c|c|c|c|c|c|}
\hline Sample & rock type & $\begin{array}{c}\text { Grain } \\
\#\end{array}$ & $\begin{array}{c}\text { LA-ICPMS } \\
\text { spot }\end{array}$ & ${ }^{59} \mathrm{Co}$ & ${ }^{60} \mathrm{Ni}$ & ${ }^{63} \mathrm{Cu}$ & ${ }^{66} \mathrm{Zn}$ & ${ }^{71} \mathrm{Ga}$ & ${ }^{72} \mathrm{Ge}$ & ${ }^{75} \mathrm{As}$ & ${ }^{88} \mathrm{Sr}$ & ${ }^{89} \mathrm{Y}$ & ${ }^{93} \mathrm{Nb}$ & ${ }^{95} \mathrm{Mo}$ \\
\hline \multirow[t]{10}{*}{ ELL-14-06 } & vein ore & 2 & no05a18 & 117.1 & 299 & & 63 & 1.12 & & 24.2 & 4.24 & 7.42 & 17.8 & \\
\hline & & 2 & no05a19 & 121.6 & 307 & & 55.6 & 1.36 & & 39.2 & 5.26 & 10.36 & 26.5 & \\
\hline & & 2 & no05a20 & 112.6 & 301 & & 38 & 1.97 & & 28.2 & 3.35 & 7.34 & 15.5 & \\
\hline & & 2 & no05a21 & 111 & 297 & & & 0.9 & & 16.3 & 3.16 & 5.69 & 14.5 & \\
\hline & & 2 & no05a22 & 103.9 & 250 & & 49.7 & 0.93 & & 19.4 & 1.98 & 5.47 & 15.6 & \\
\hline & & 3 & no05a23 & 108.3 & 334 & & 61 & 1.24 & & 13.2 & 3.15 & 5.31 & 18 & \\
\hline & & 3 & no05a24 & 159 & 279 & & 54.2 & & & 6.5 & 1.42 & 2.55 & 5.84 & \\
\hline & & 3 & no05a26 & 114.2 & 266.6 & 40 & 47.8 & 1.33 & & 26.8 & 4.21 & 9.02 & 25.1 & \\
\hline & & 3 & no05a27 & 68.1 & 249 & & 50.6 & & & 9.9 & 1.73 & 3.42 & 9.22 & \\
\hline & & 3 & no05a 28 & 124 & 255 & 76 & 44 & & & 17 & 2.76 & 4.63 & 11.1 & \\
\hline \multirow[t]{8}{*}{ LAS-14-07 } & pyroclastic & 1 & no05d 21 & 264.3 & 496 & 54.6 & 1127 & 68 & & & 6.8 & 19.4 & 20.2 & 5.8 \\
\hline & dacite & 1 & no0 $0 \mathrm{~d} 22$ & 264.5 & 320 & 54.9 & 1151 & 70.4 & & & 8.6 & 26.1 & 20.1 & \\
\hline & & 1 & no0 $05 \mathrm{~d} 23$ & 252.6 & 263 & 50.9 & 1087 & 63.9 & & & 4.2 & 5.8 & 19.3 & \\
\hline & & 1 & no0 $5 \mathrm{~d} 24$ & 263.8 & 279 & 48.7 & 1009 & 67.8 & & & & 1.06 & 20.5 & 4.9 \\
\hline & & 2 & no05d27 & 214.8 & 340 & 50.1 & 1309 & 52.9 & & & & 1.24 & 99.3 & 13.1 \\
\hline & & 3 & no0 $0 \mathrm{~d} 30$ & 236 & 373 & 63.3 & 1665 & 66.4 & & & & & 5.35 & 6.7 \\
\hline & & 4 & no05d33 & 246.6 & 368 & 51.3 & 1408 & 68.1 & & & 11 & & 14.1 & \\
\hline & & 4 & no05d34 & 242 & 382 & 46.2 & 1277 & 61.6 & & & & & 15.3 & \\
\hline
\end{tabular}


Appendix V. (Cont.)

LA-

\begin{tabular}{|c|c|c|c|c|c|c|c|c|c|c|c|c|c|c|c|}
\hline Sample & rock type & Grain \# & ICPMS spot & ${ }^{107} \mathrm{Ag}$ & ${ }^{115} \mathrm{In}$ & ${ }^{118} \mathrm{Sn}$ & ${ }^{121} \mathrm{Sb}$ & ${ }^{138} \mathrm{Ba}$ & ${ }^{140} \mathrm{Ce}$ & ${ }^{181} \mathrm{Ta}$ & ${ }^{184} \mathrm{~W}$ & ${ }^{197} \mathrm{Au}$ & ${ }^{205} \mathrm{Tl}$ & ${ }^{208} \mathrm{~Pb}$ & ${ }^{232} \mathrm{Th}$ \\
\hline \multirow[t]{10}{*}{ ELL-14-06 } & vein ore & 2 & no05a18 & & & 13.8 & & 4.16 & 48.7 & 0.233 & 0.28 & & & & 24.4 \\
\hline & & 2 & no05a19 & & 0.198 & 16.71 & 4.97 & 5.51 & 68.3 & 0.35 & 0.65 & & & & 34.5 \\
\hline & & 2 & no05a20 & & & 15.4 & & 4.23 & 51 & & 0.31 & & & & 26.7 \\
\hline & & 2 & no05a21 & & & 12.66 & 2.27 & 4.18 & 40.8 & 0.24 & 0.59 & & & 0.25 & 23.3 \\
\hline & & 2 & no05a22 & & 0.245 & 14.2 & & 2.41 & 50.6 & & 0.38 & & 0.0025 & & 24.2 \\
\hline & & 3 & no05a23 & & 0.149 & 17.2 & & 6.3 & 48.4 & & 0.42 & & & & 21.8 \\
\hline & & 3 & no05a24 & & & 10.5 & & 1.61 & 17.07 & 0.164 & 0.081 & 0.06 & & & 9.09 \\
\hline & & 3 & no05a26 & & 0.153 & 12.8 & 3.44 & 5.71 & 57.7 & 0.31 & 0.47 & & & & 31.5 \\
\hline & & 3 & no05a27 & & & 14.8 & & 3.43 & 25.2 & & 0.08 & & & & 12.14 \\
\hline & & 3 & no05a28 & & & 13.8 & & 3.81 & 36.7 & & 0.3 & & 0.005 & & 18.26 \\
\hline \multirow[t]{8}{*}{ LAS-14-07 } & pyroclastic & 1 & no05d21 & & & 27.6 & & & 44.8 & 0.81 & 0.32 & & & & 3.49 \\
\hline & dacite & 1 & no05d22 & & & 27.4 & & 1.57 & 61.8 & 0.78 & 0.36 & & & & 4.63 \\
\hline & & 1 & no05d 23 & & & 25 & & & 13.9 & 0.91 & 0.58 & & & & 0.99 \\
\hline & & 1 & no05d24 & & & 25.2 & & & 3 & 1 & 0.52 & & & & 0.34 \\
\hline & & 2 & no05d27 & & 0.9 & 41 & & 1.46 & 0.52 & 5.92 & 1.36 & & & & 1.41 \\
\hline & & 3 & no05d30 & & & 26.2 & & & 0.68 & 0.26 & & & 0 & & 0.061 \\
\hline & & 4 & no05d33 & & 0.6 & 24.2 & & 51 & 0.65 & 0.86 & 0.24 & & & 1.81 & 0.24 \\
\hline & & 4 & no05d34 & & 0.57 & 22.2 & & & & 1.54 & 0 & & 0 & & 0.13 \\
\hline
\end{tabular}


Appendix VI. LA-ICPMS and EPMA spot analysis locations on BSE images for Kiruna and El Laco magnetite

KRN-10-02 map

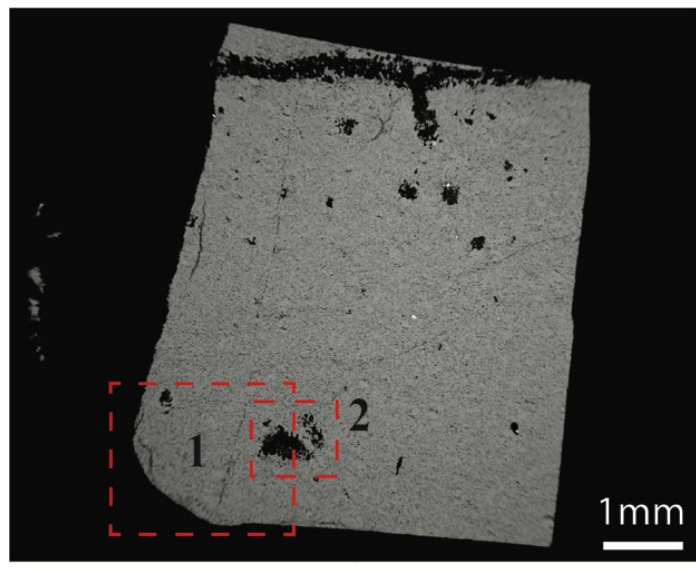

KRN-10-02(2)

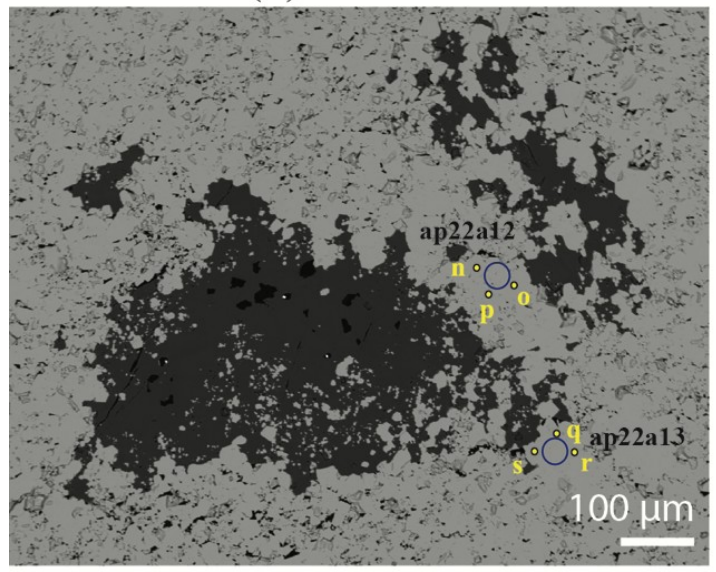

$\mathrm{K}-1(1)$

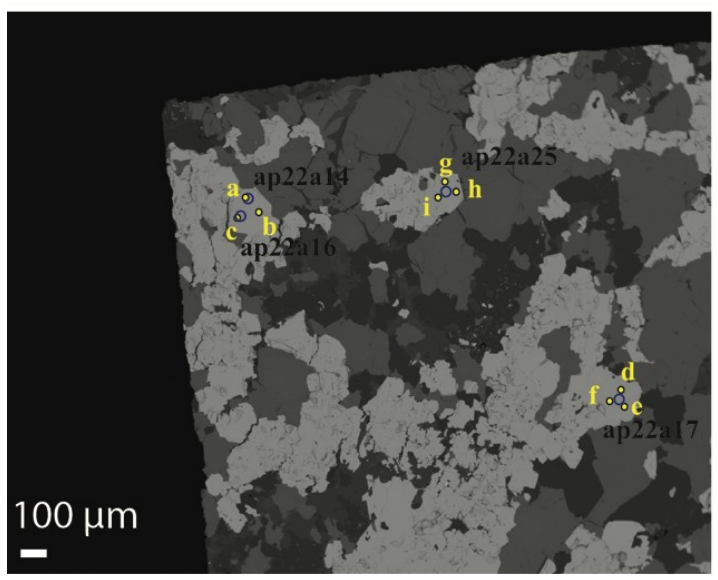

KRN-10-02(1)

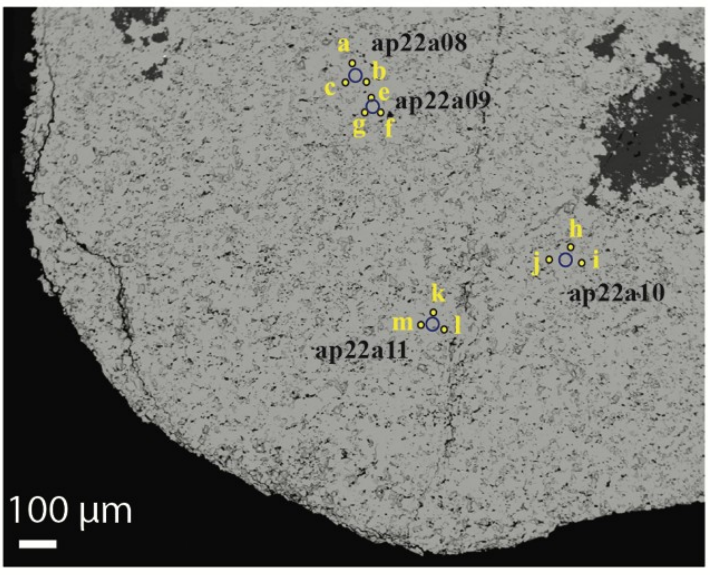

K-1 map

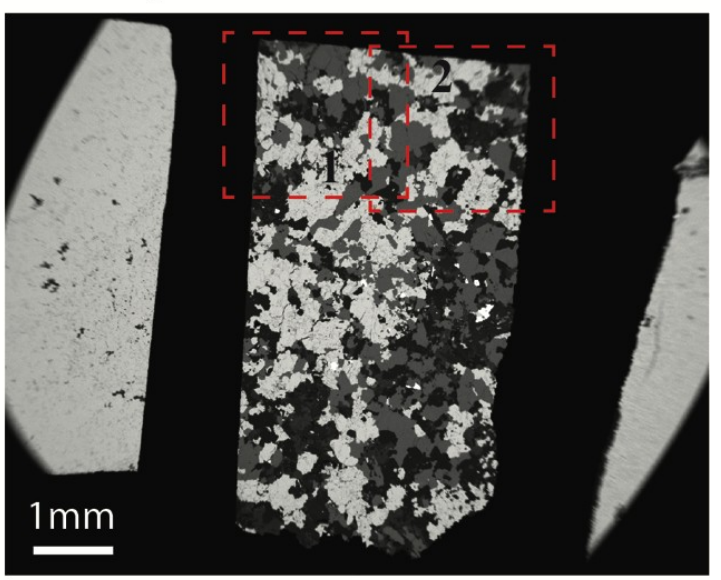

$\mathrm{K}-1(2)$

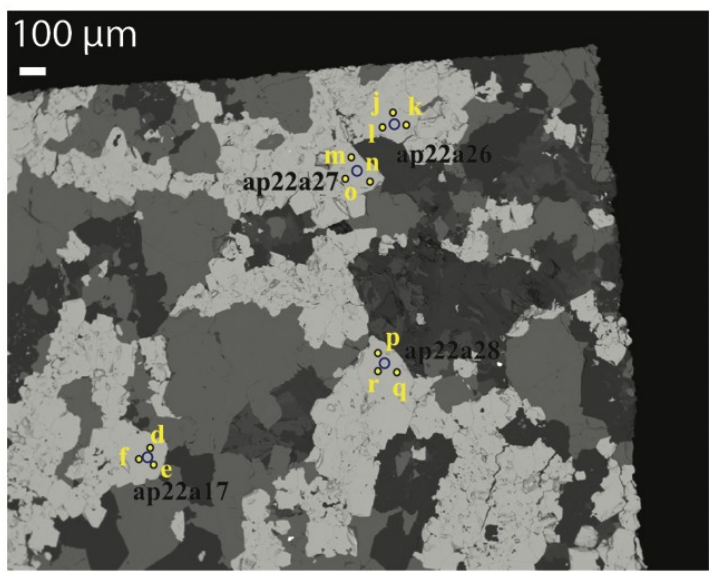


Appendix VI. (Cont.)

K-2 map

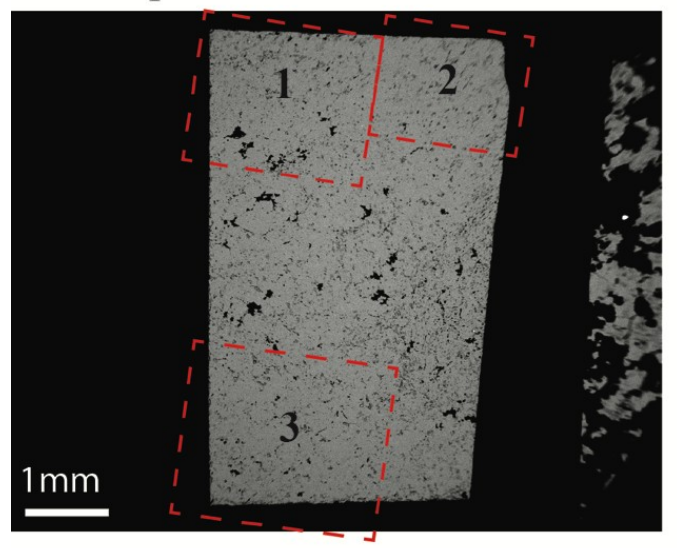

K-2(2)

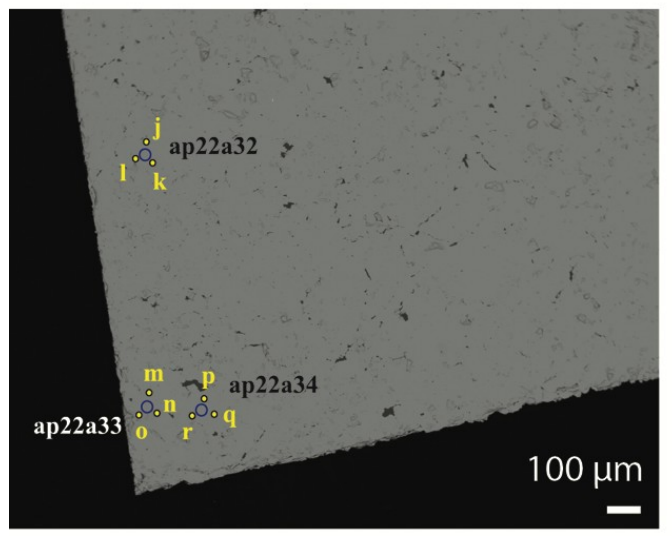

K-2(1)

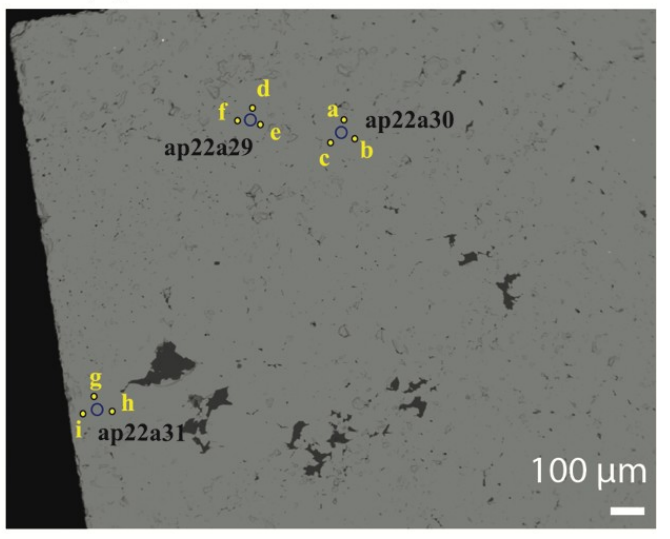

K-2(3)

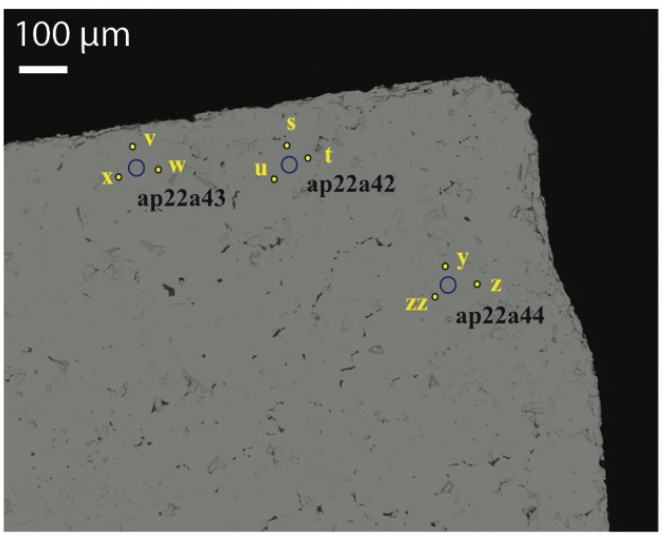


Appendix VI. (Cont.)

KRN-11-01 map

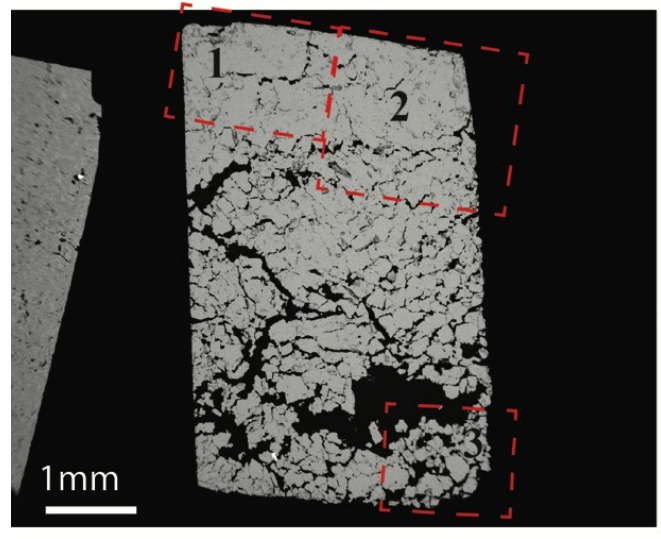

KRN-11-01(2)

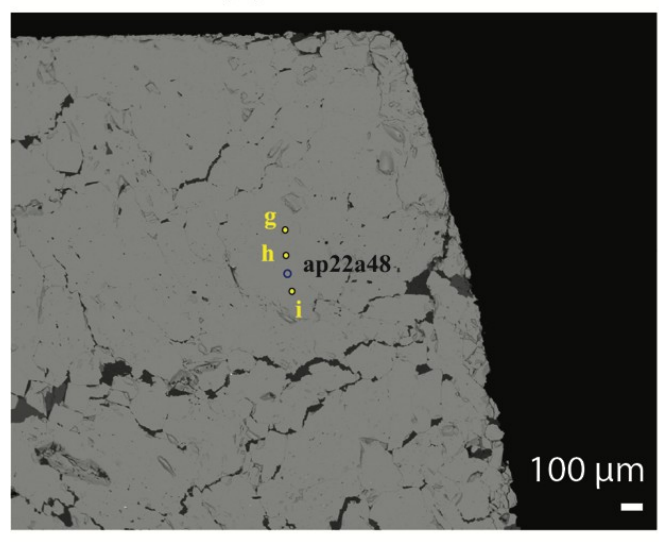

KRN-11-01(1)

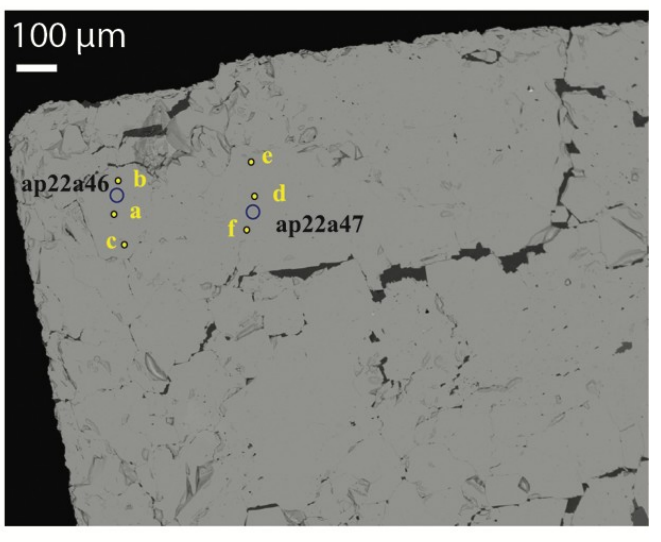

KRN-11-01(3)

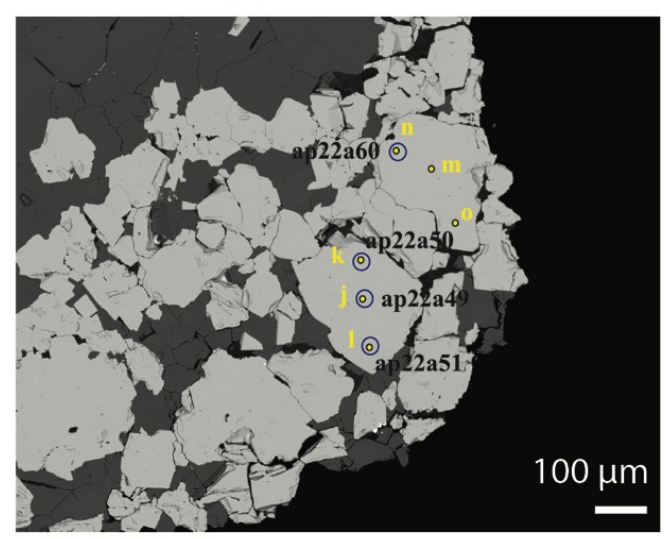


Appendix VI. (Cont.)

KRN-11-03 map

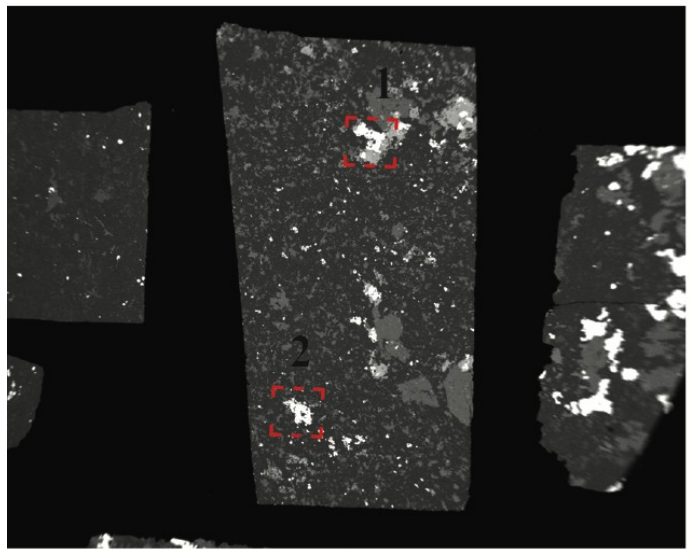

KRN-11-03(2)

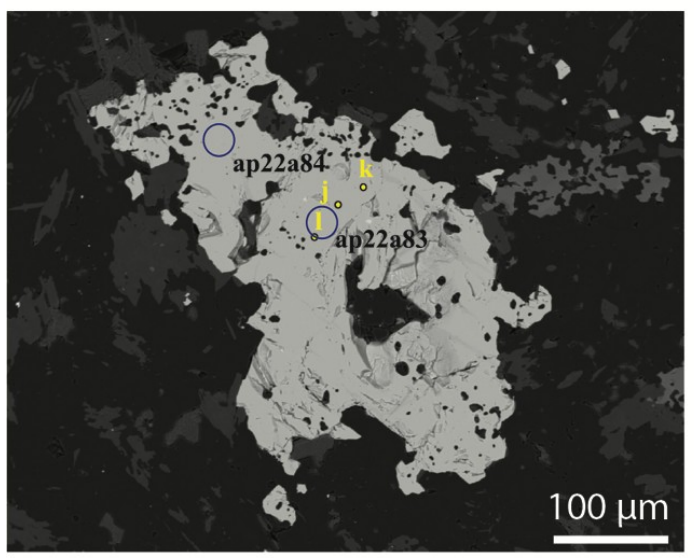

KRN-11-04(1)

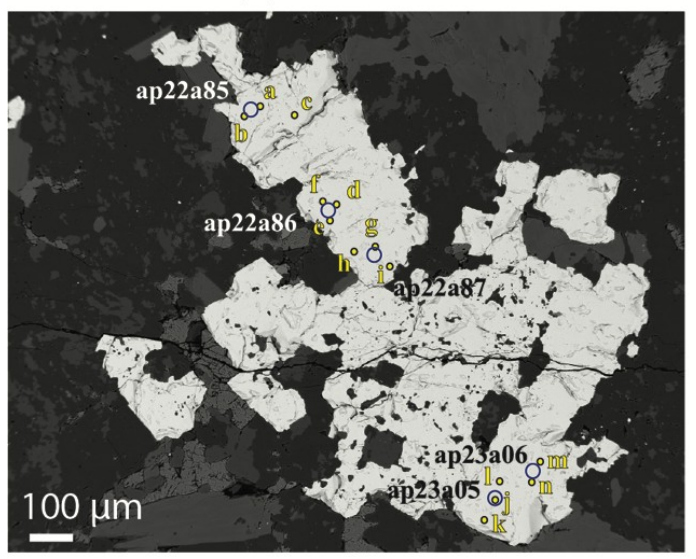

KRN-11-03(1)

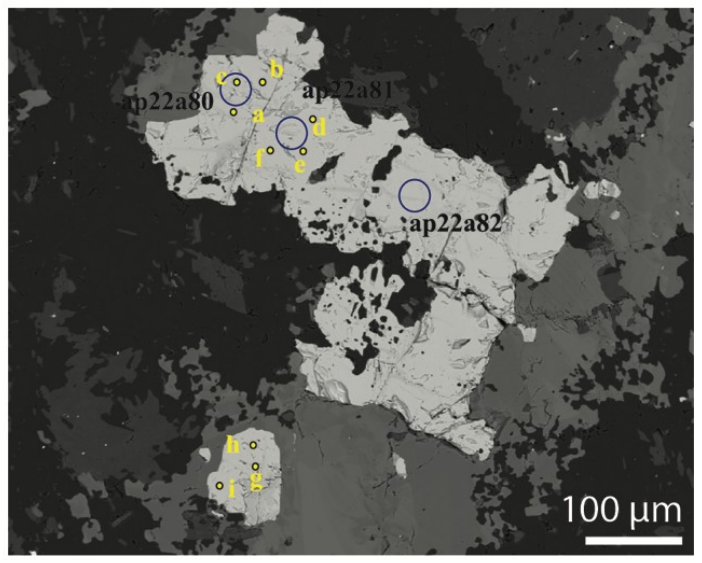

KRN-11-04 map

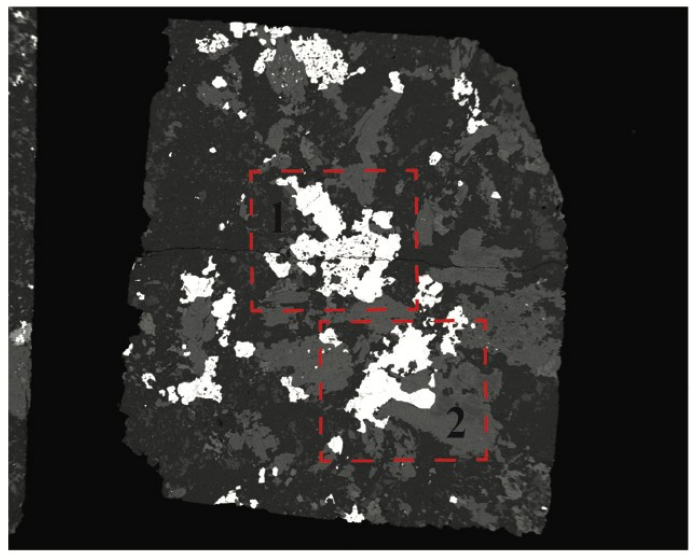

KRN-11-04(2)

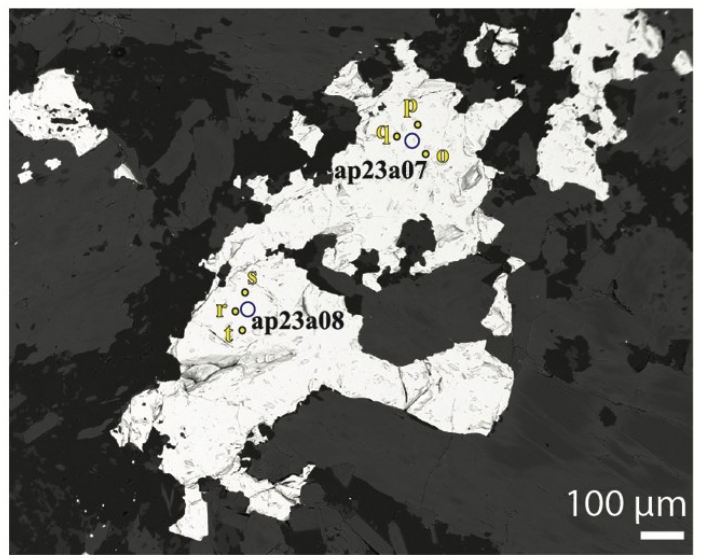


Appendix VI. (Cont.)
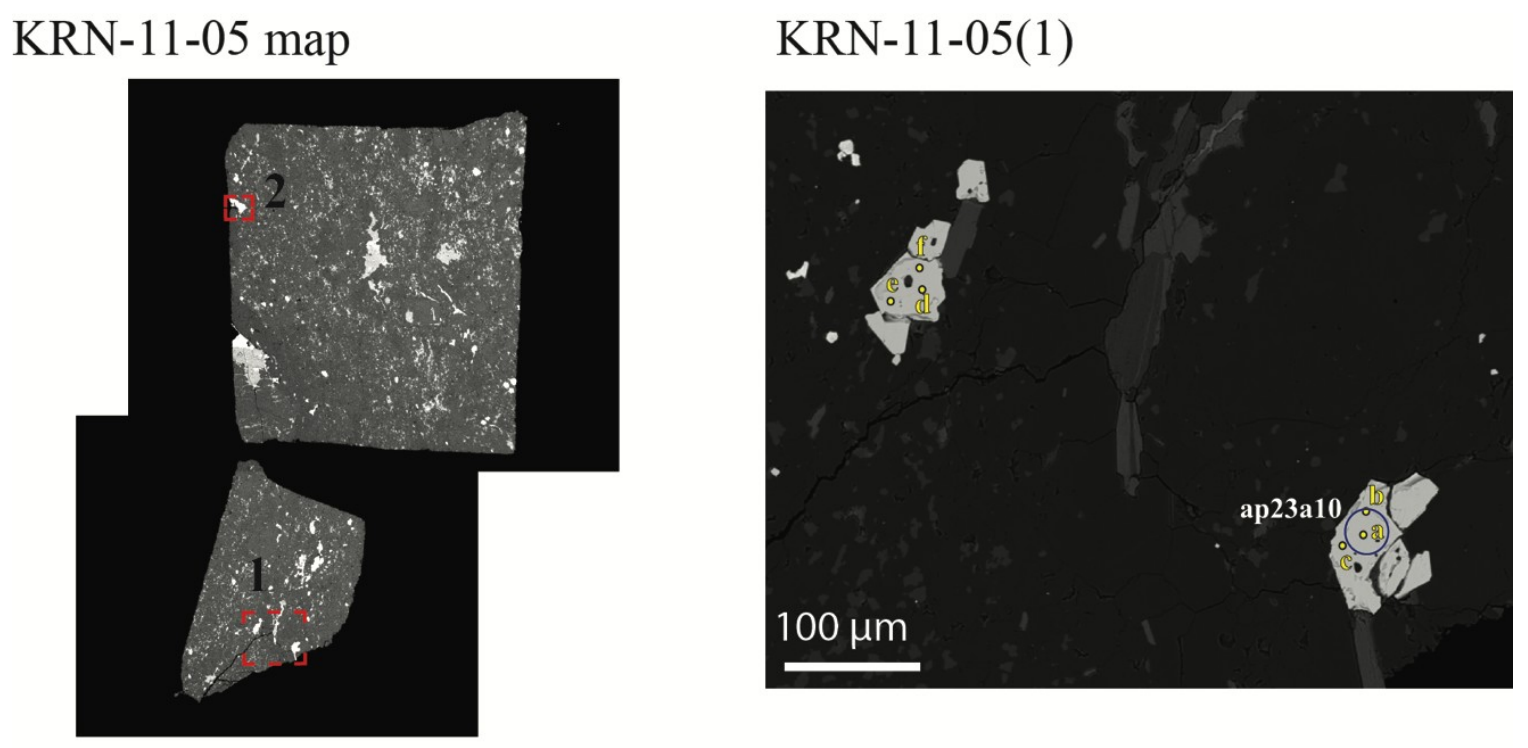

KRN-11-05(2)

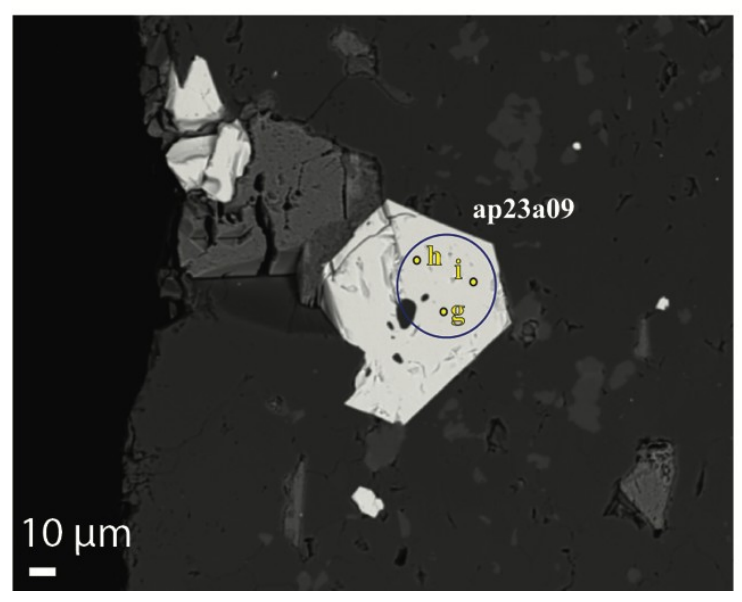


Appendix VI. (Cont.)

KRN-12-02 map

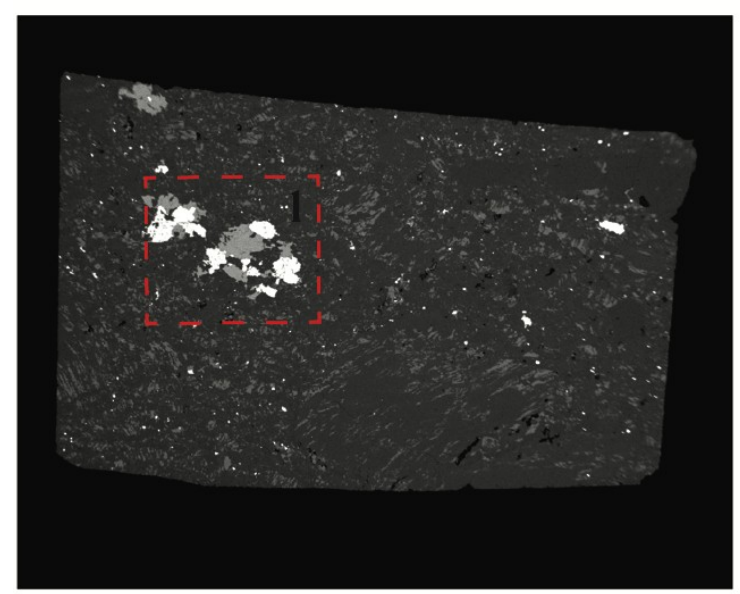

KRN-12-03 map

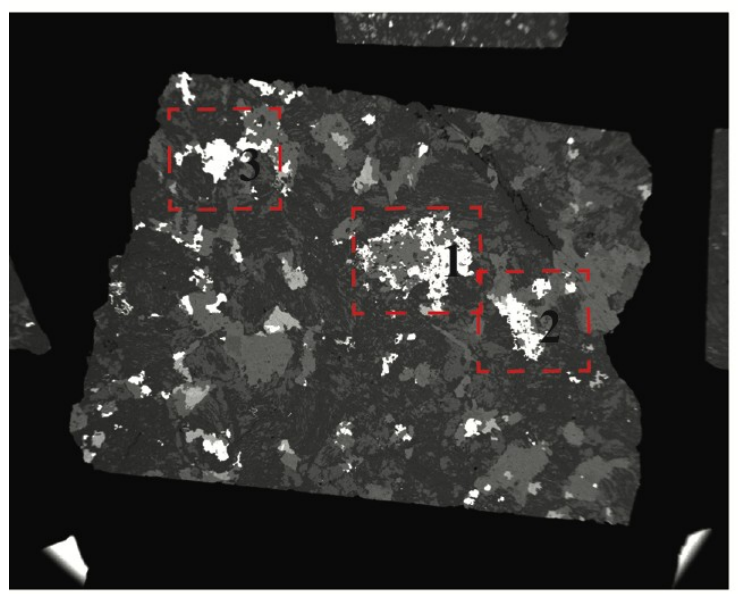

KRN-12-03(2)

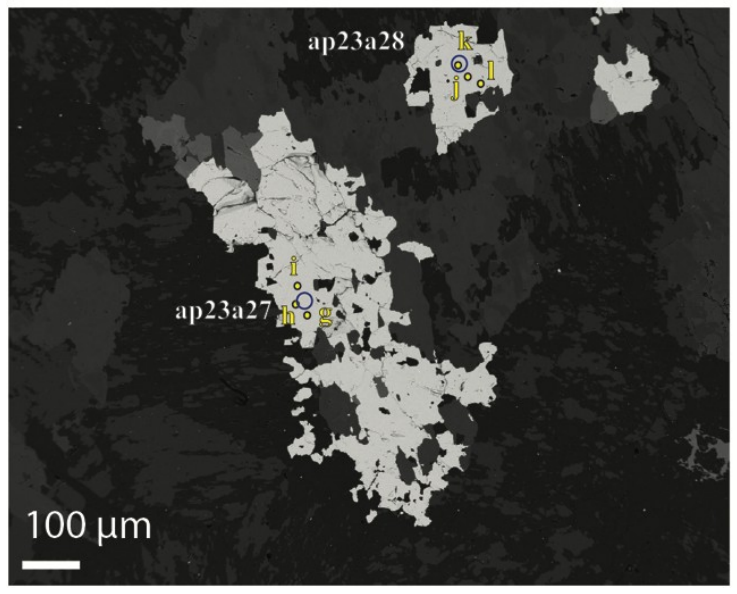

KRN-12-02

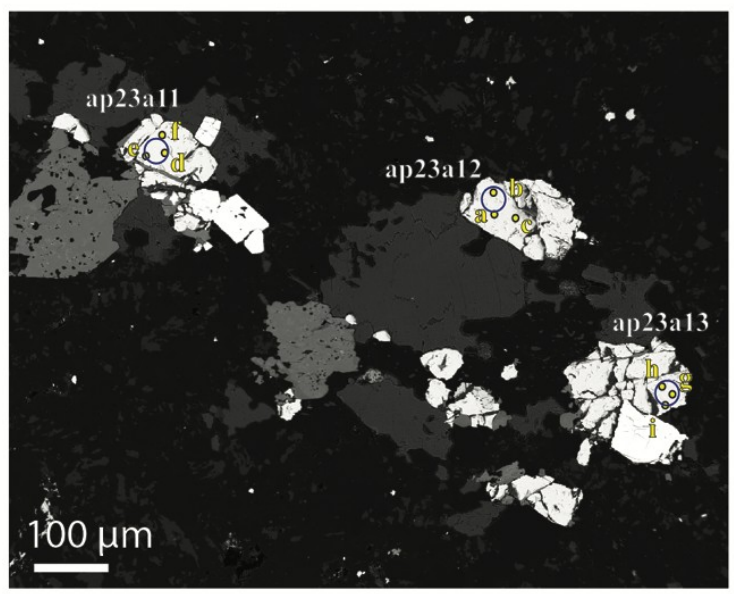

KRN-12-03(1)

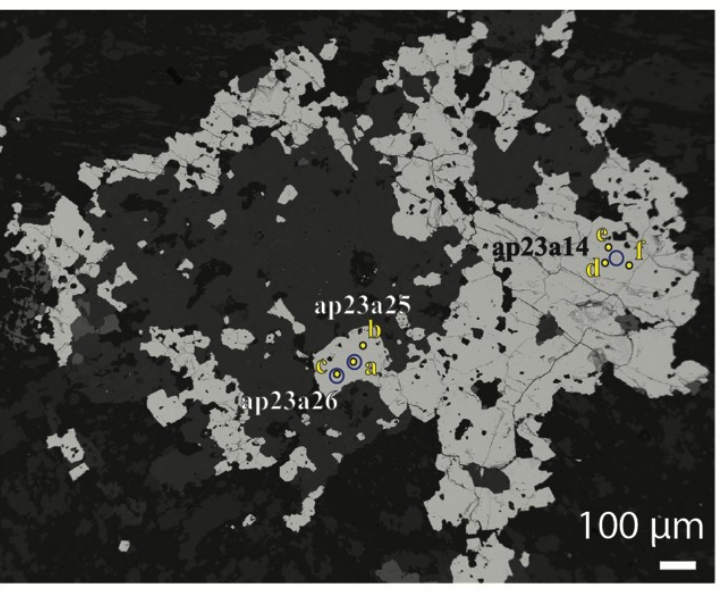

KRN-12-03(3)

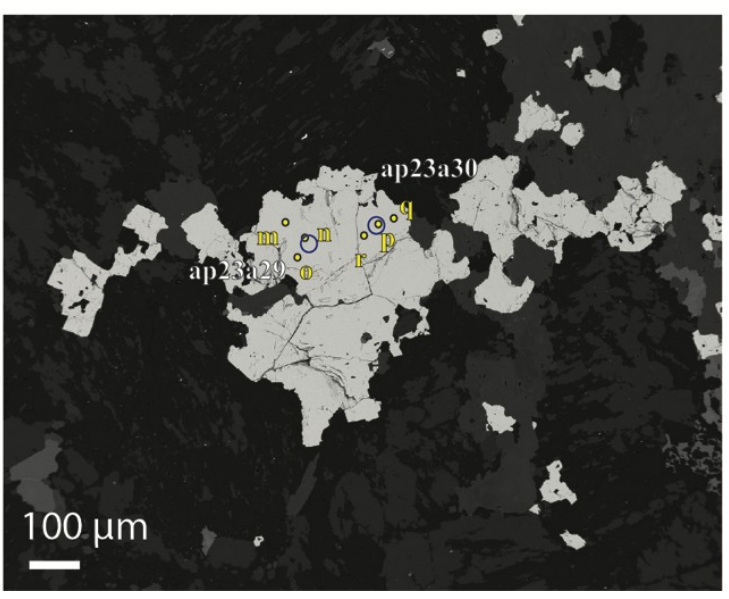


Appendix VI. (Cont.)

KRN-12-05 map

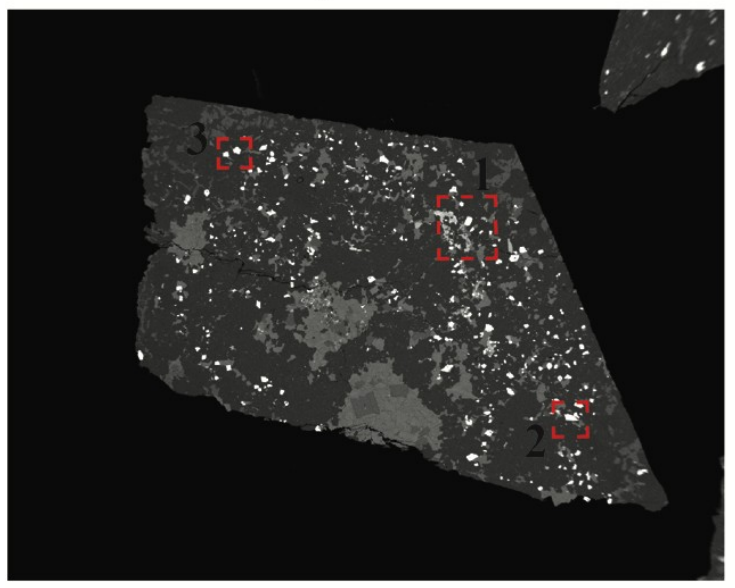

KRN-12-05(2)

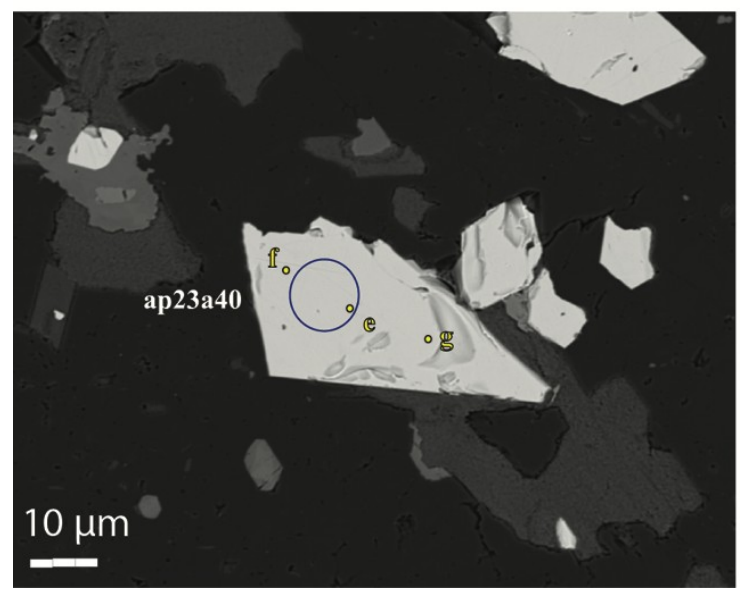

KRN-12-05(1)

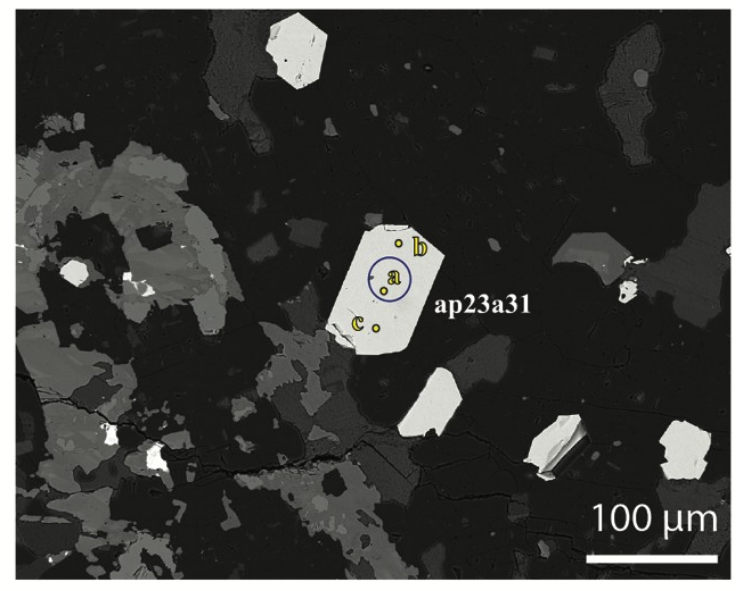

KRN-12-05(3)

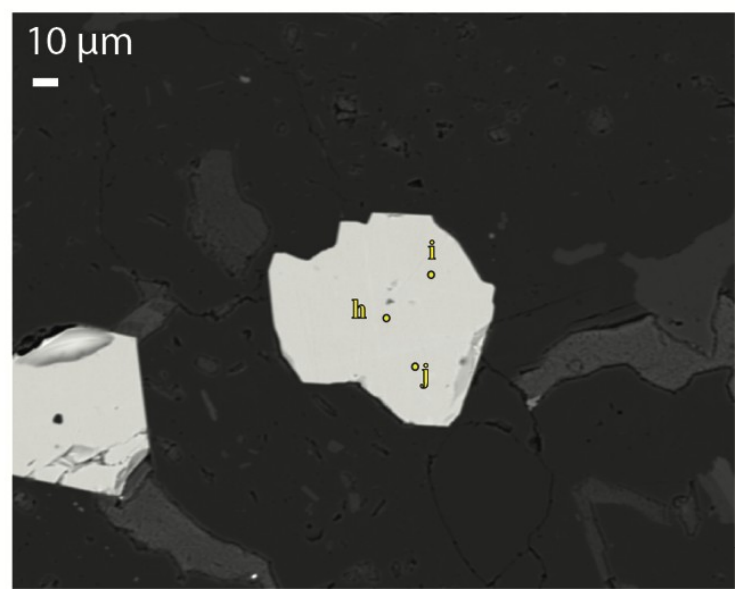


Appendix VI. (Cont.)

TUV-10-03_map(1)

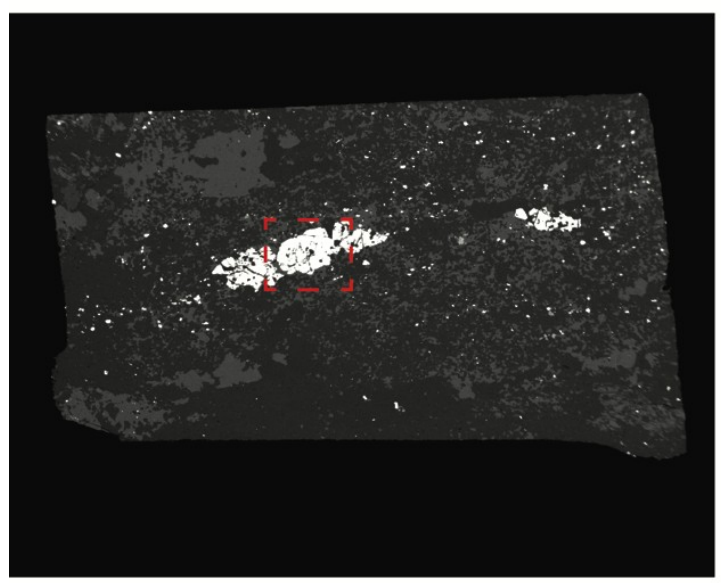

TUV-10-03(1)

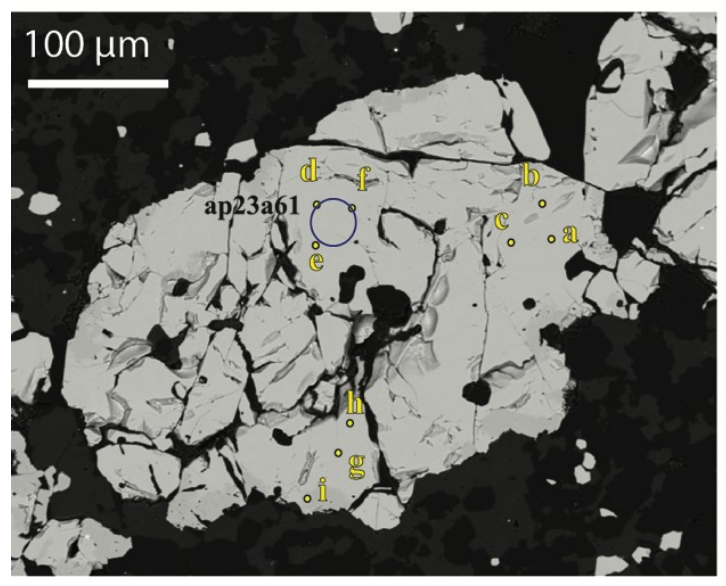

TUV-10-03_map(2)

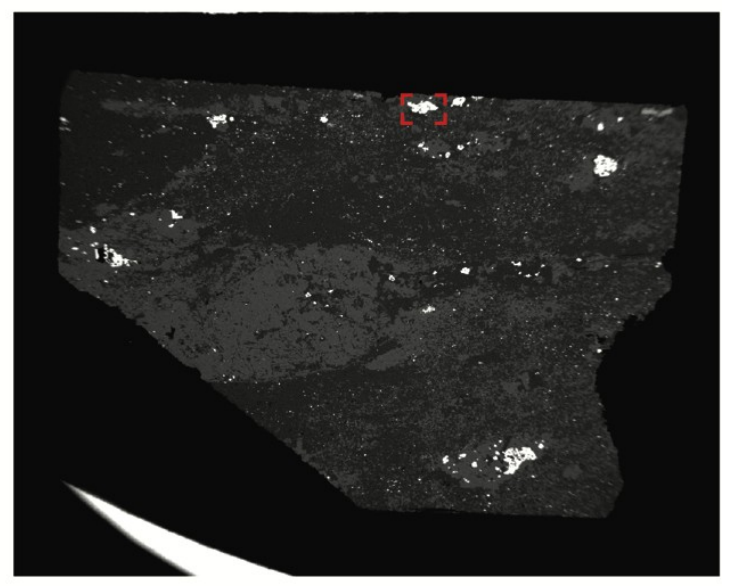

TUV-10-03(2)

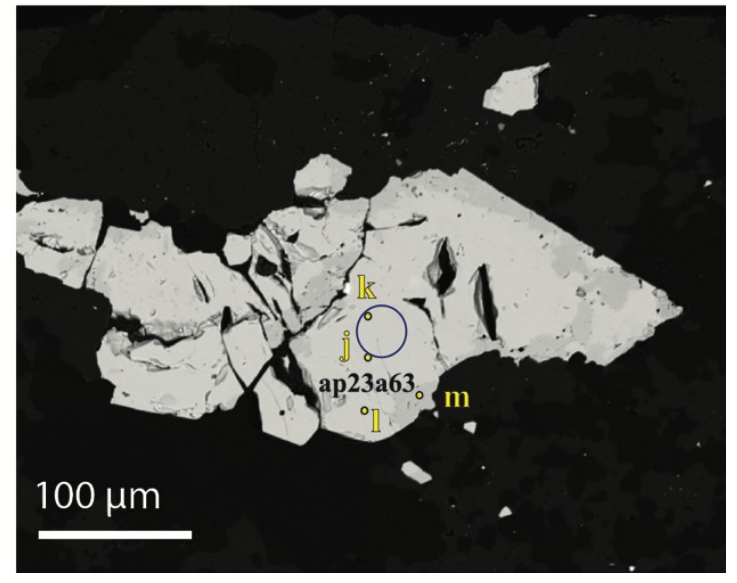


Appendix VI. (Cont.)

TUV-10-01 map

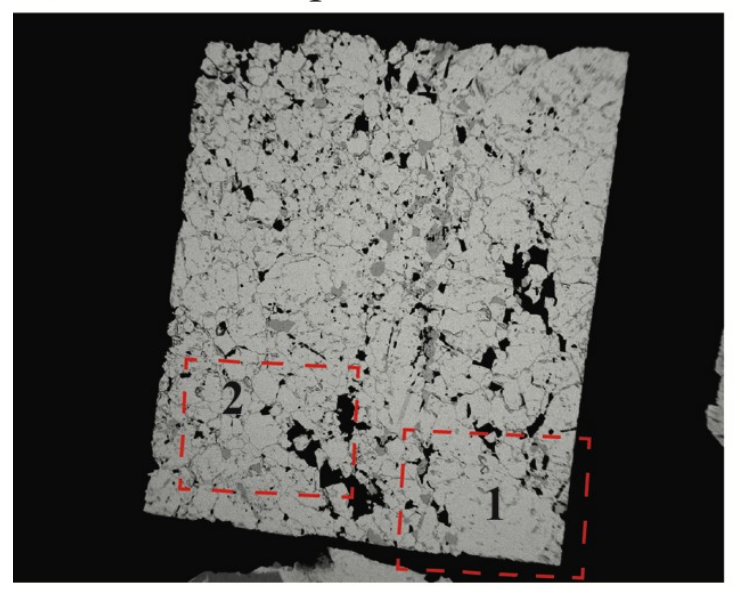

TUV-10-01(2)

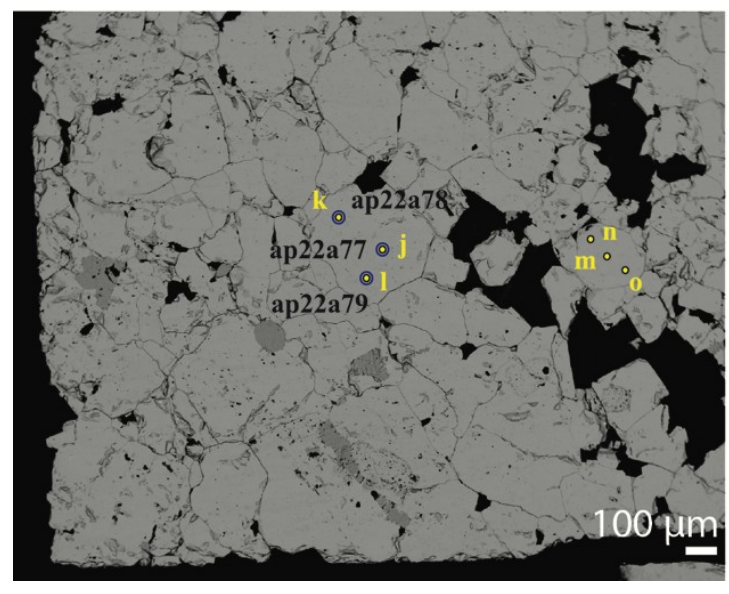

TUV-10-01(1)

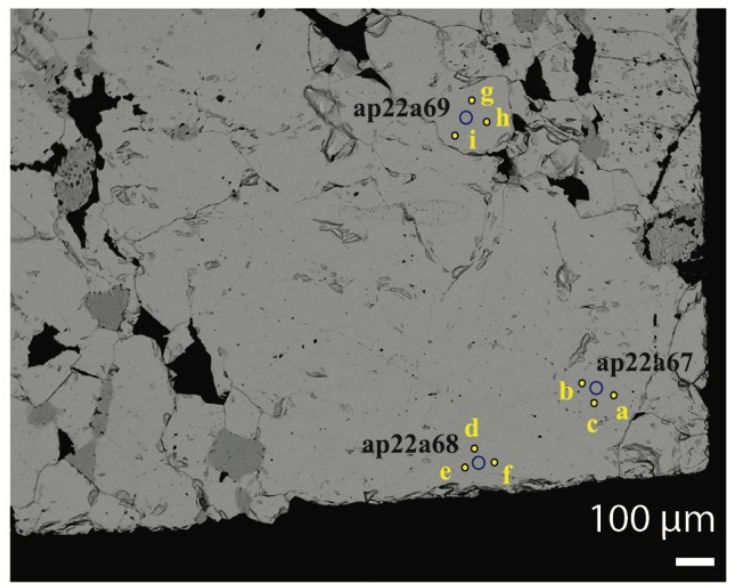


Appendix VI. (Cont.)

NUK-10-03 map

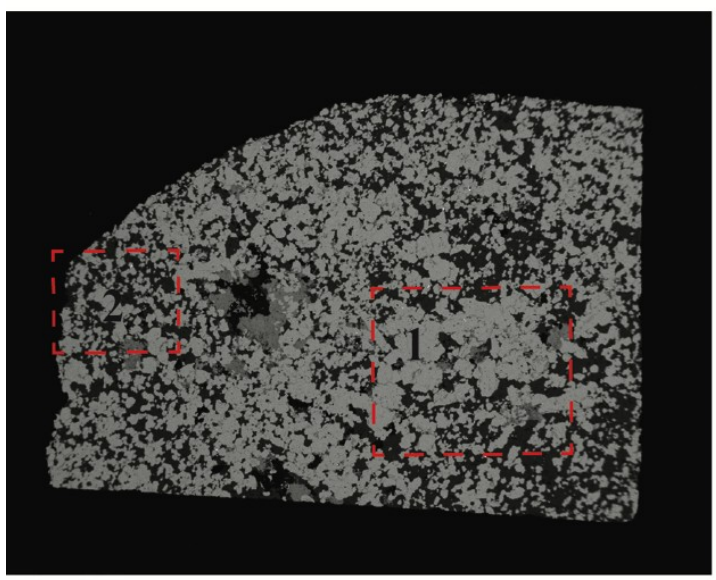

NUK-10-03(3)

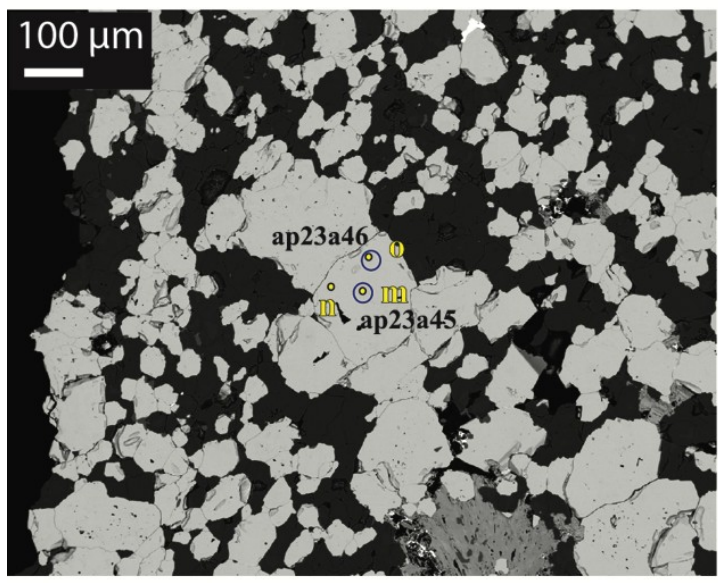

NUK-12-02(1)

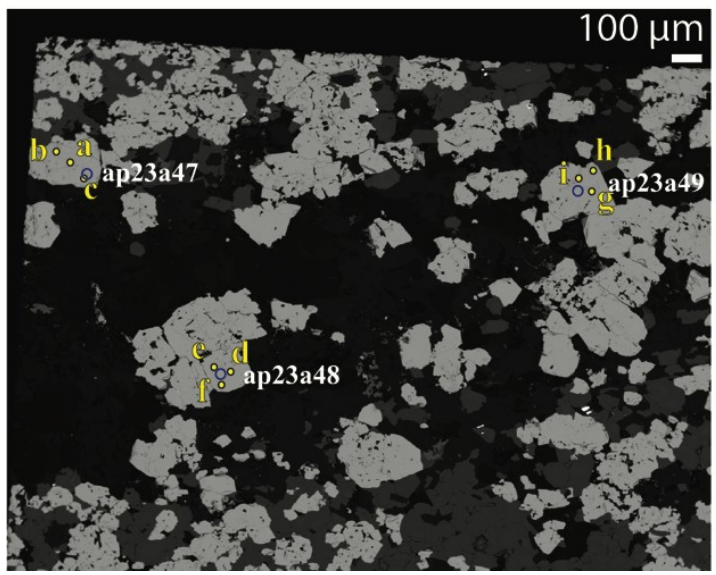

NUK-10-03(1)

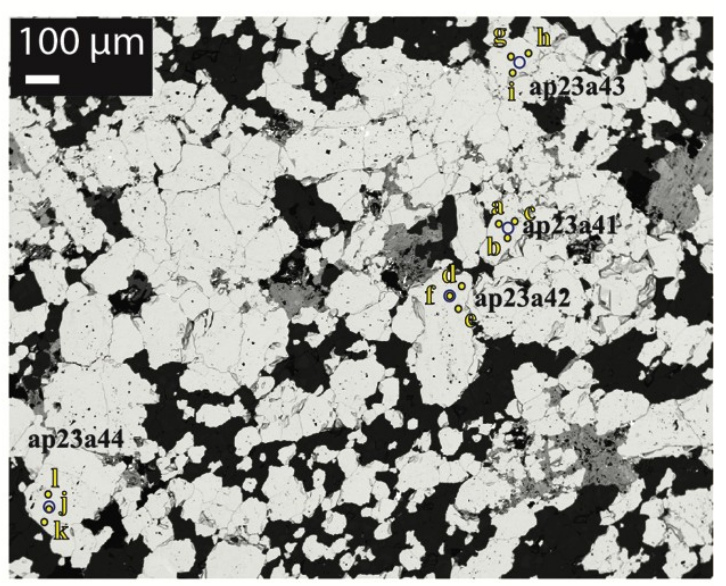

NUK-12-02 map

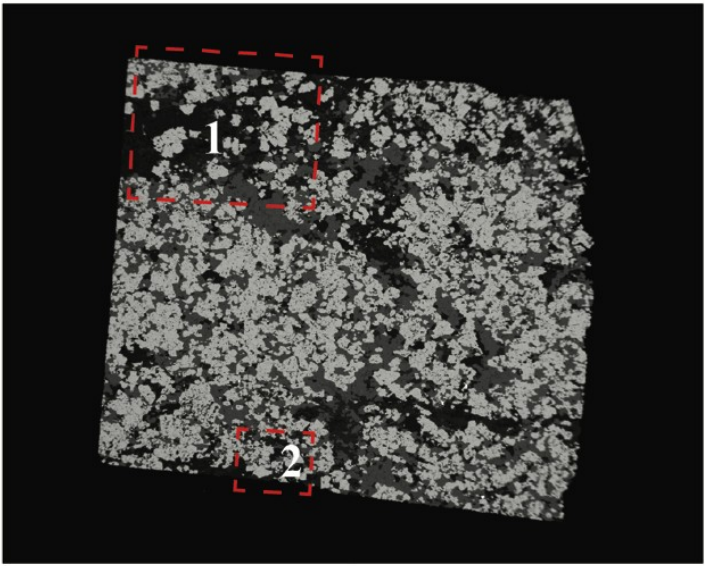

NUK-12-02(2)

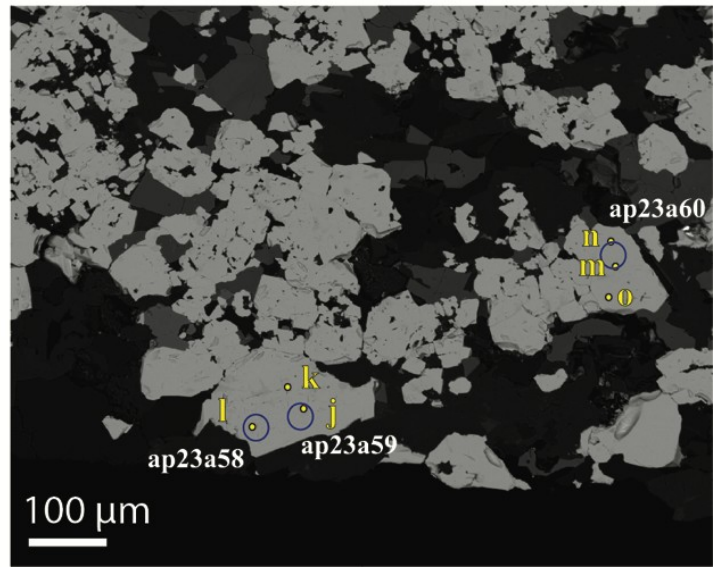


Appendix VI. (Cont.)

REK-10-01 map

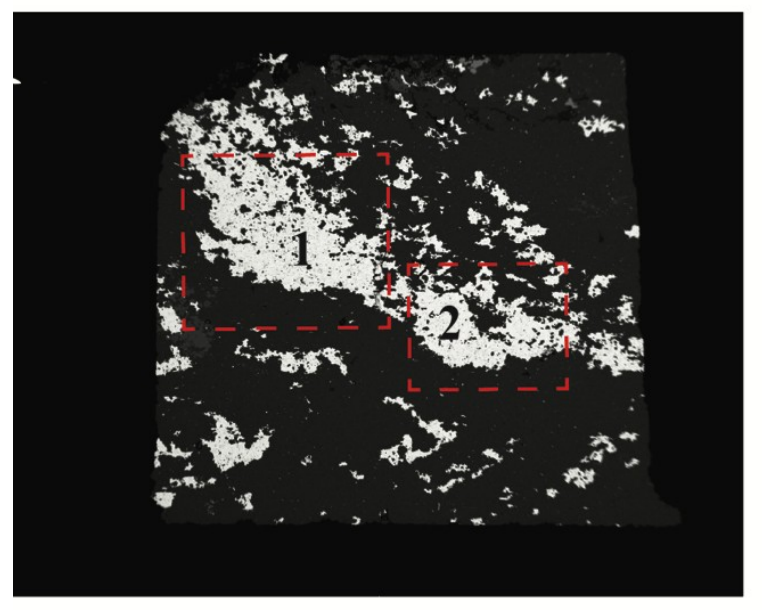

REK-10-01(1)

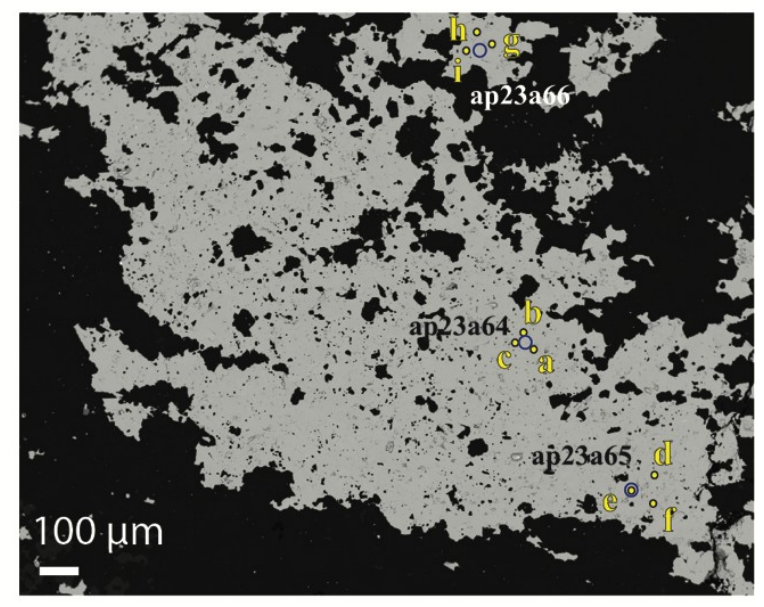

REK-10-01(2)

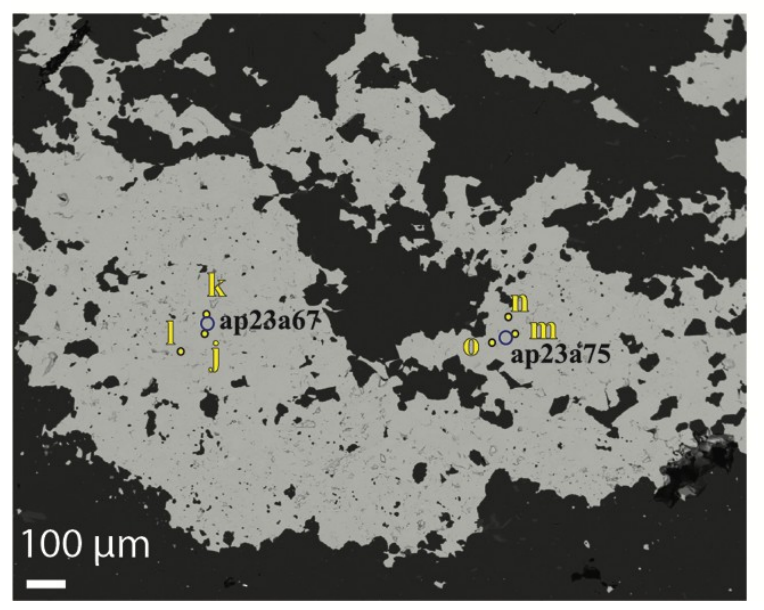


Appendix VI. (Cont.)

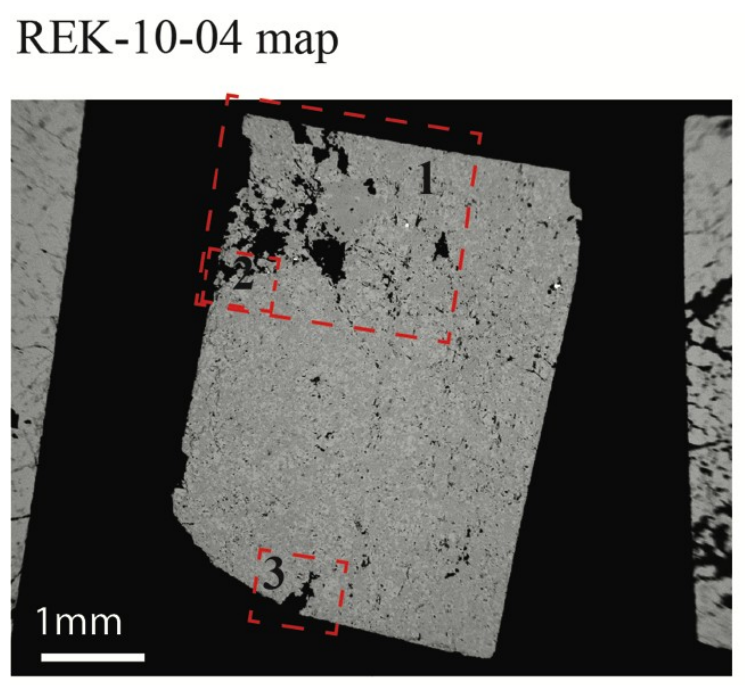

REK-10-04(1)
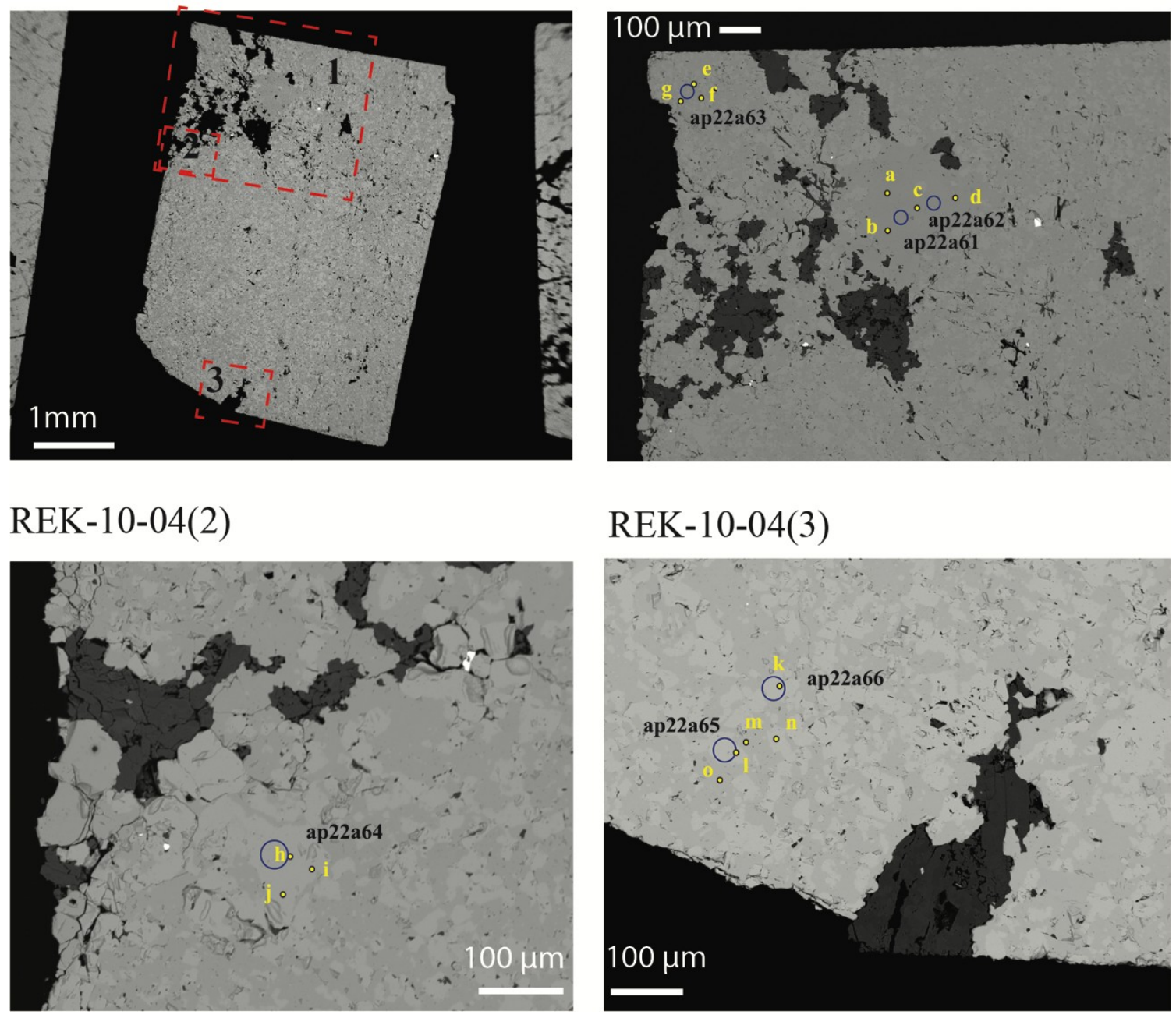

REK-10-04(3)

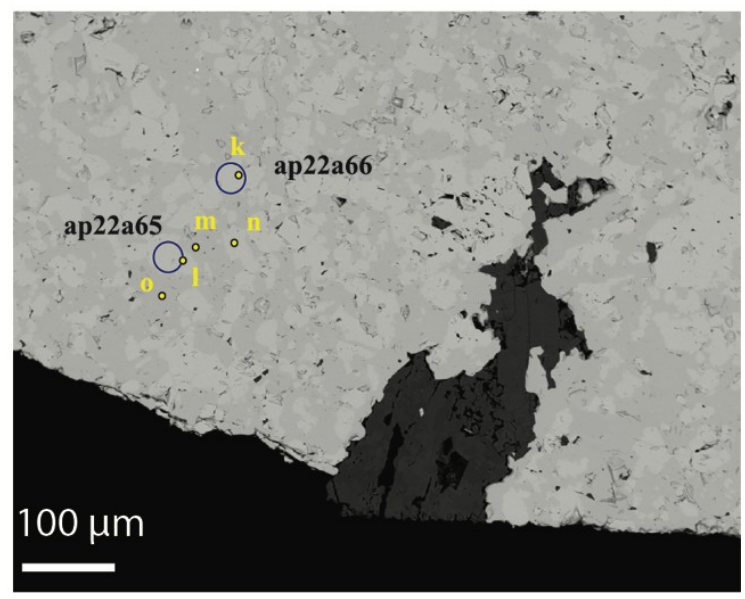


Appendix VI. (Cont.)

REK-12-02 map

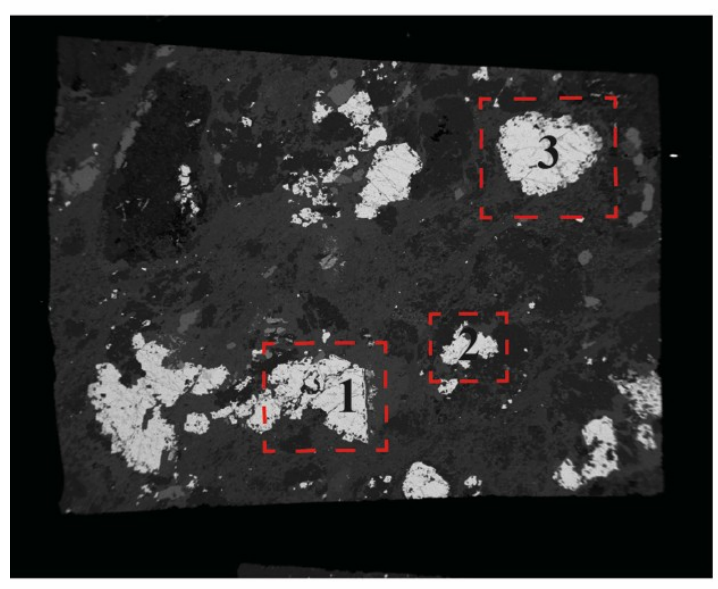

REK-12-02(2)

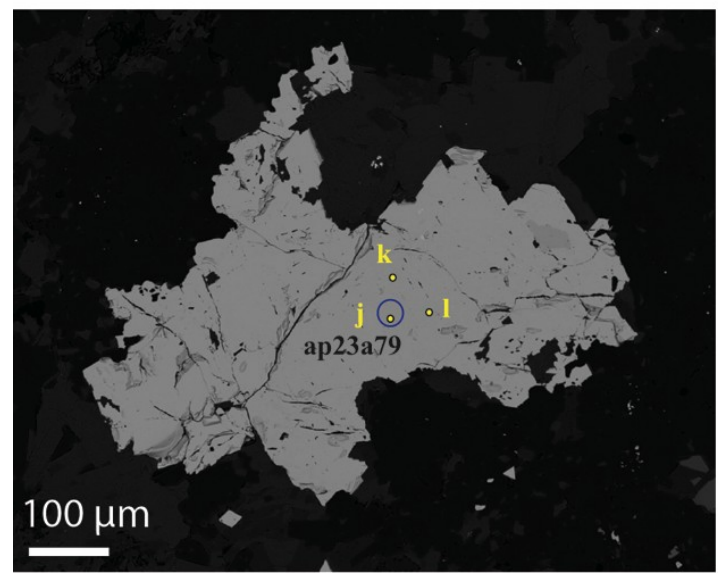

REK-12-02(1)

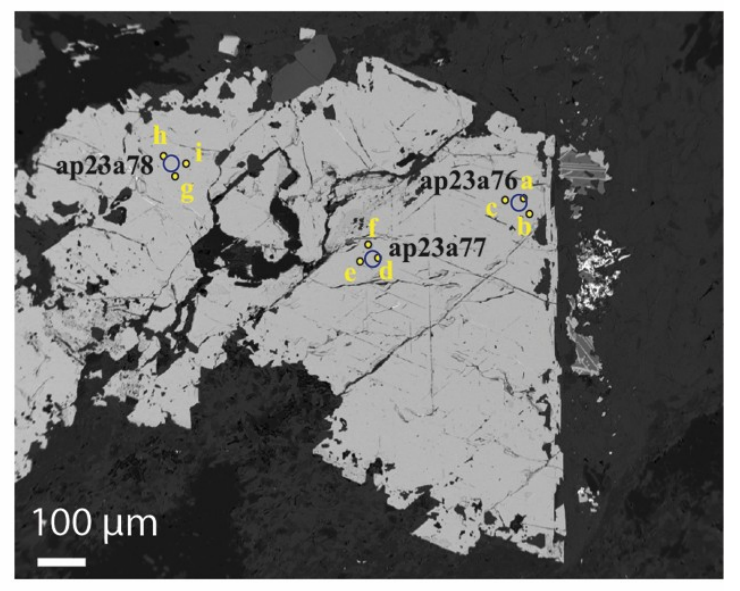

REK-12-02(3)

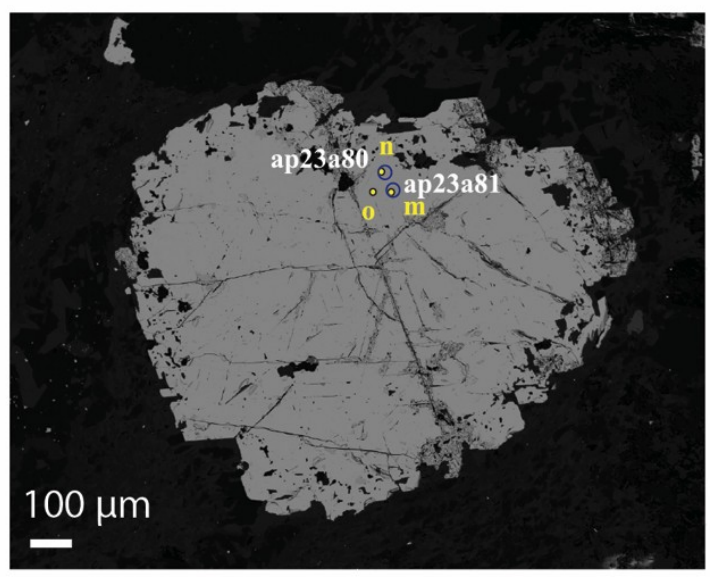


Appendix VI. (Cont.)

ELL-14-02 map

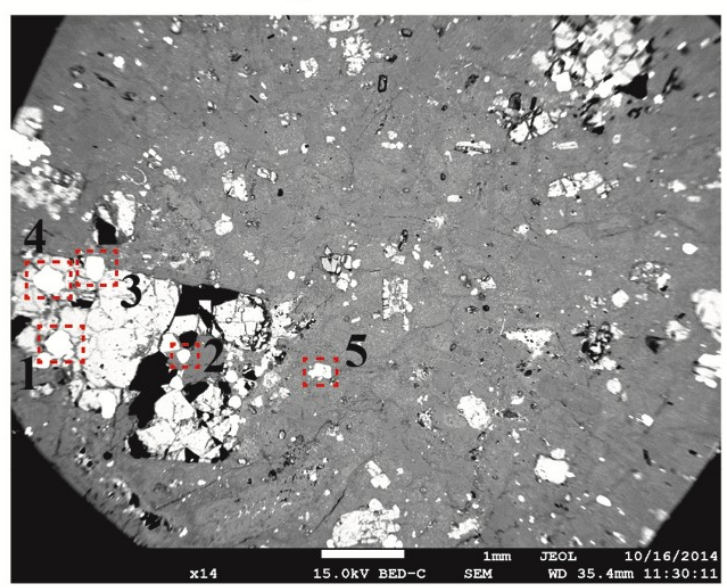

ELL-14-02 (2)

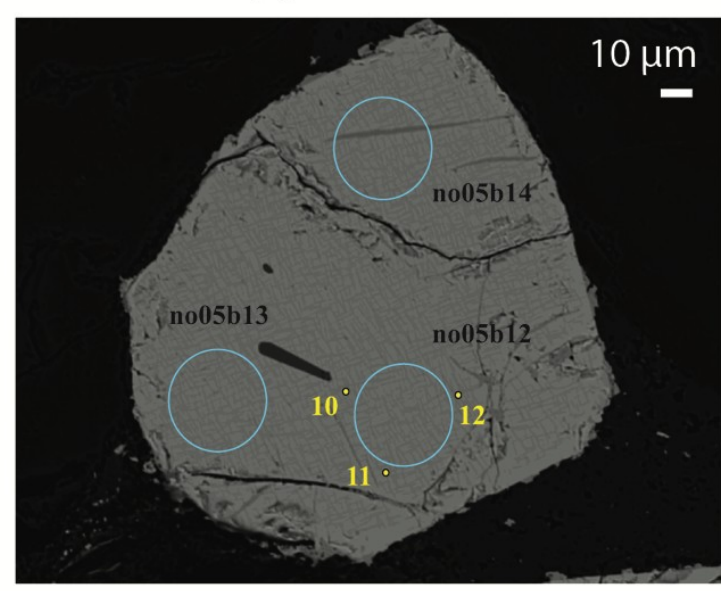

ELL-14-02 (4)

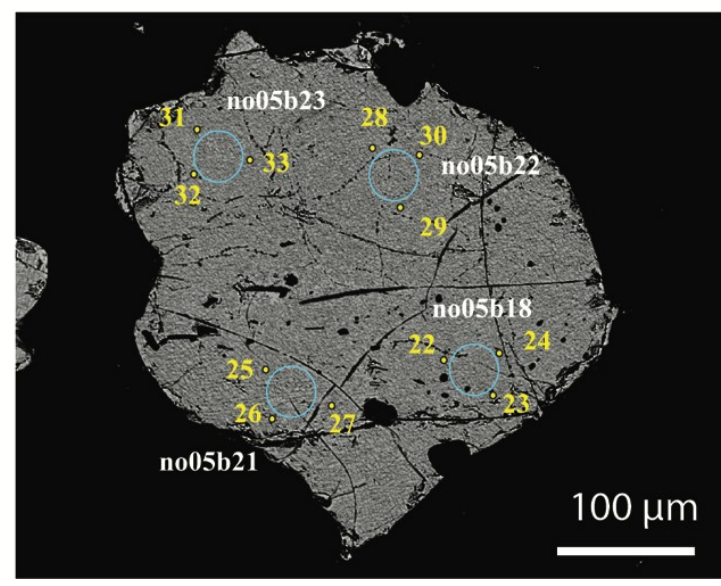

ELL-14-02 (1)

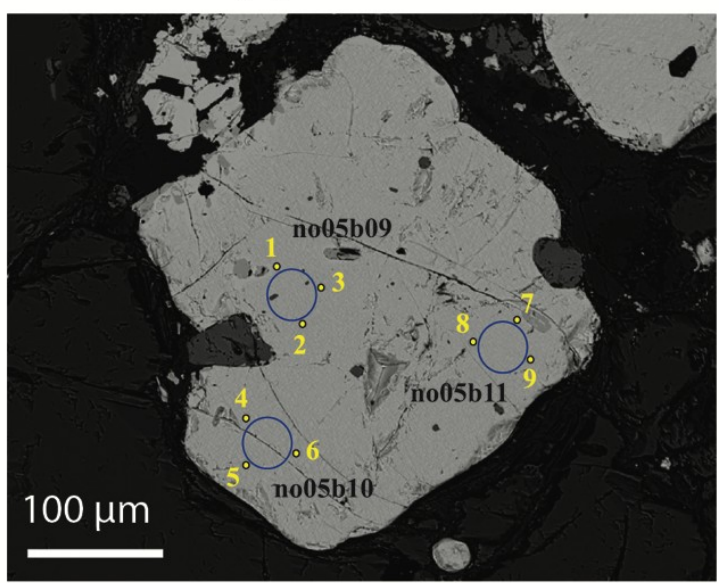

ELL-14-02 (3)

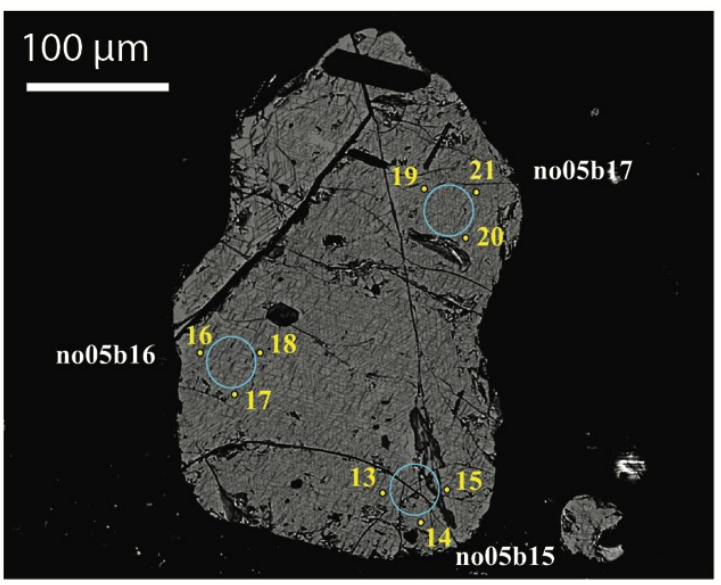

ELL-14-02 (5)

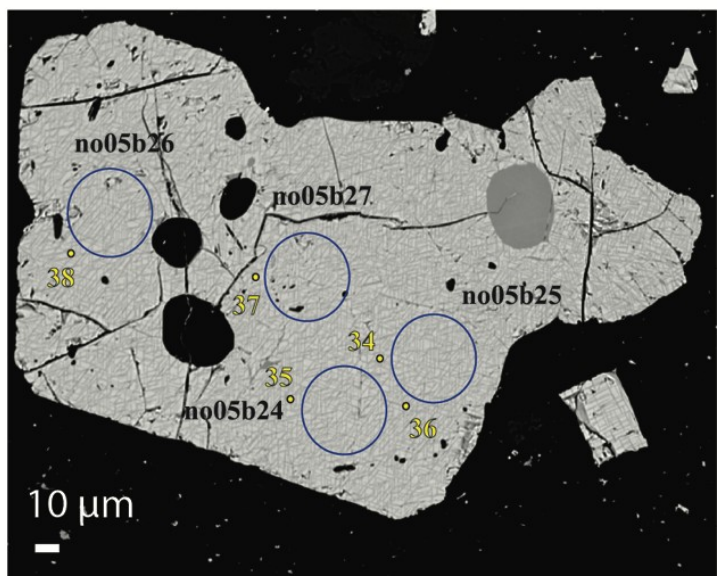


Appendix VI. (Cont.)

ELL-14-04 map

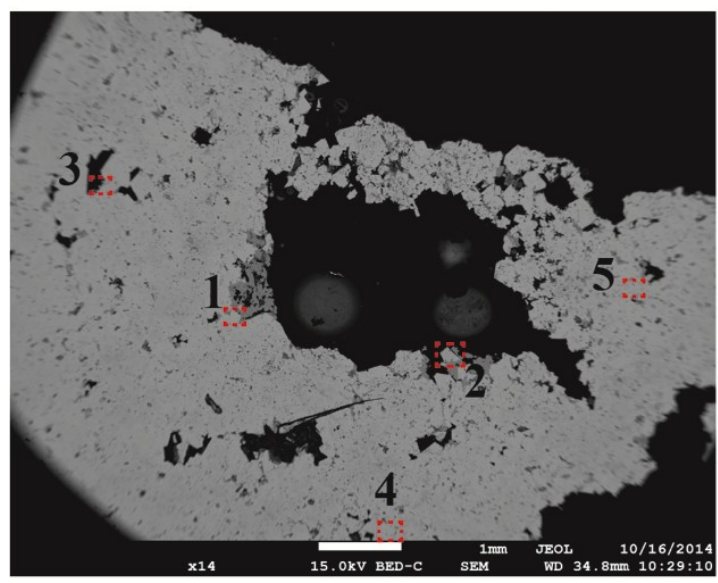

ELL-14-04 (2)

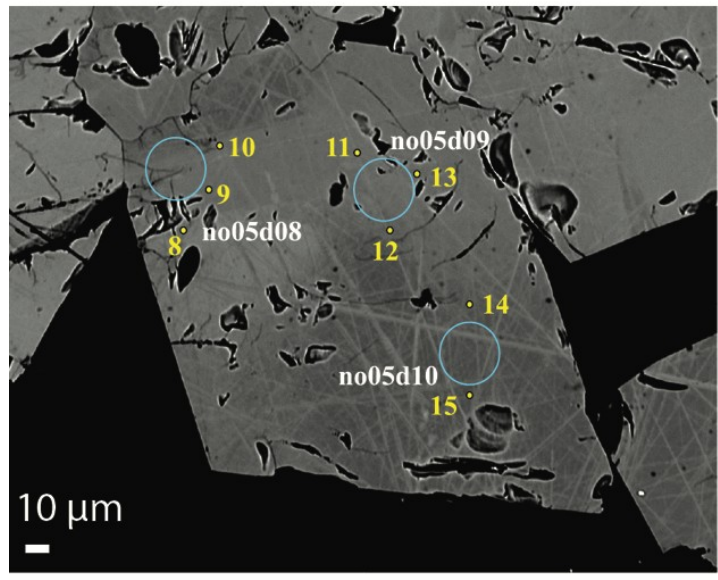

ELL-14-04 (4)

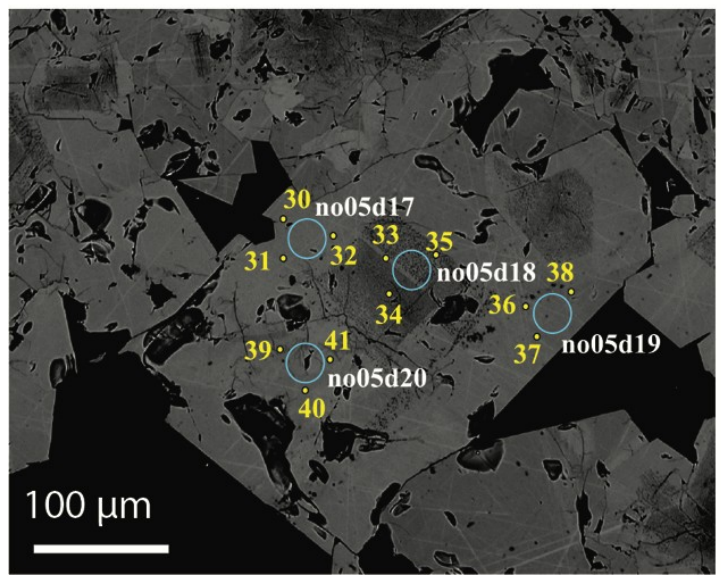

ELL-14-04 (1)

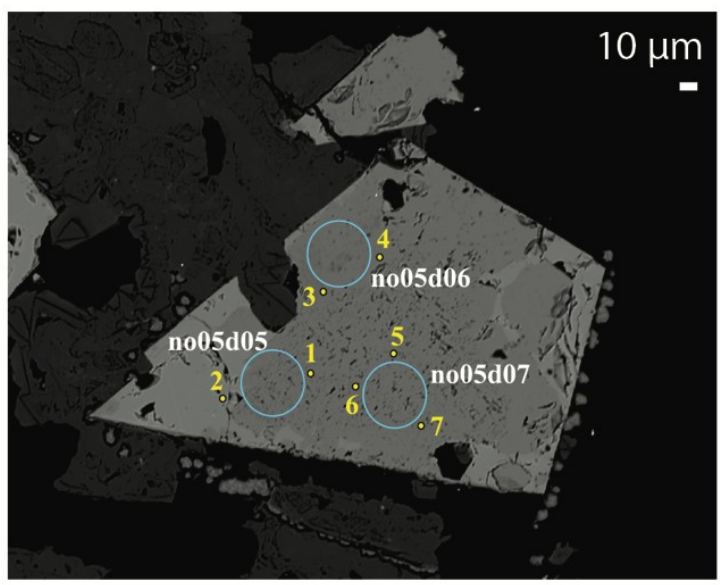

ELL-14-04 (3)

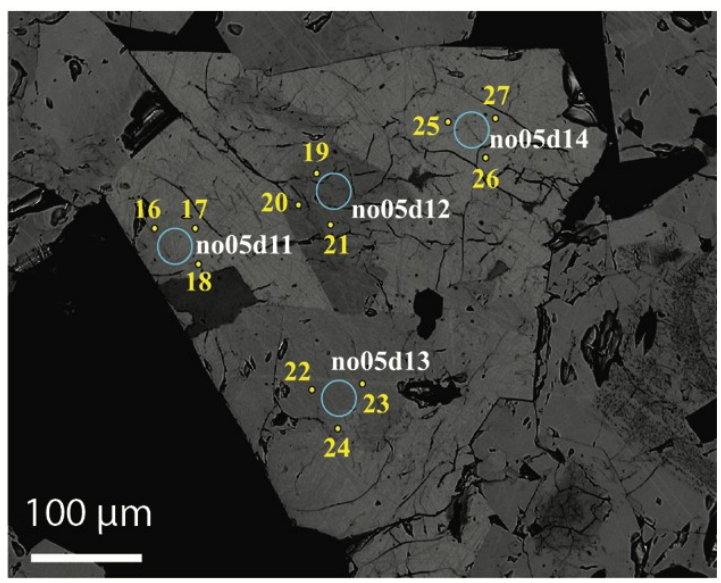


Appendix VI. (Cont.)

ELL-14-05 map

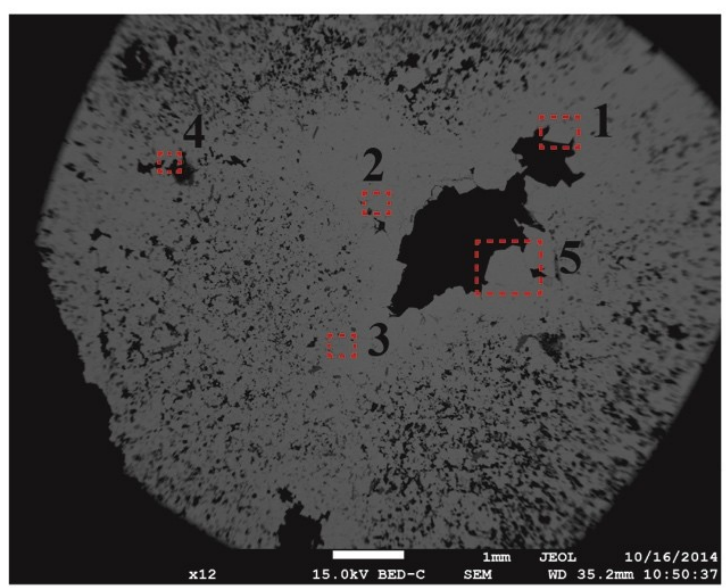

ELL-14-05 (2)

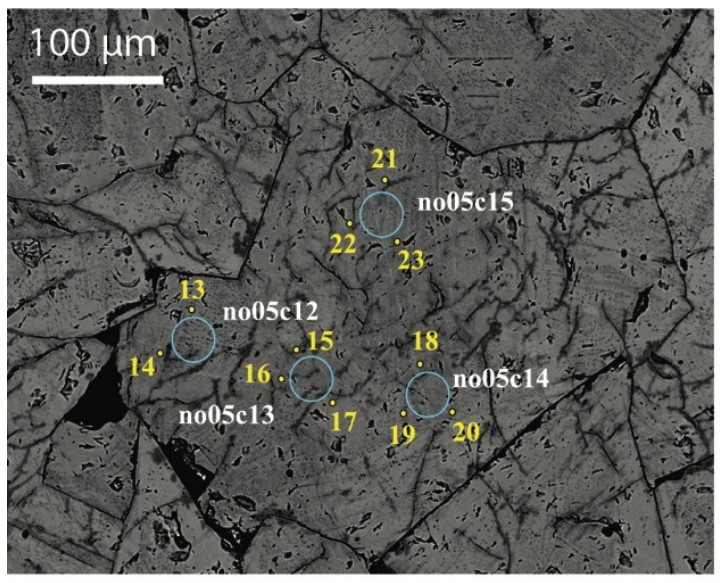

ELL-14-05 (4)

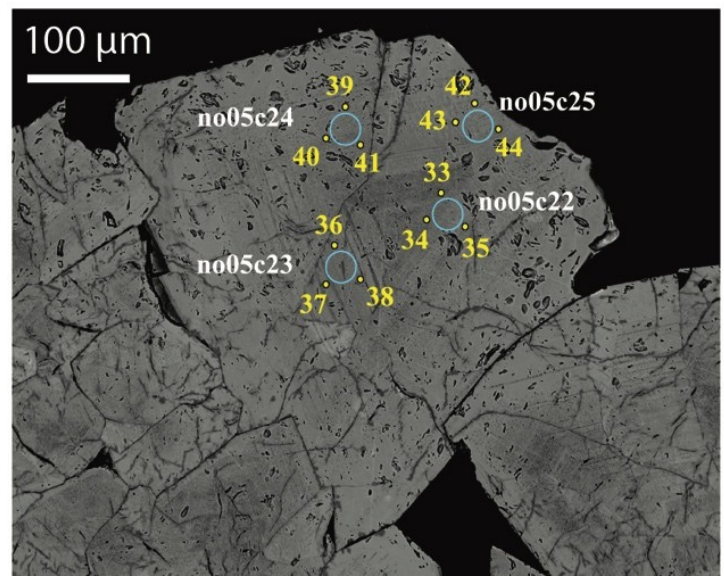

ELL-14-05 (1)

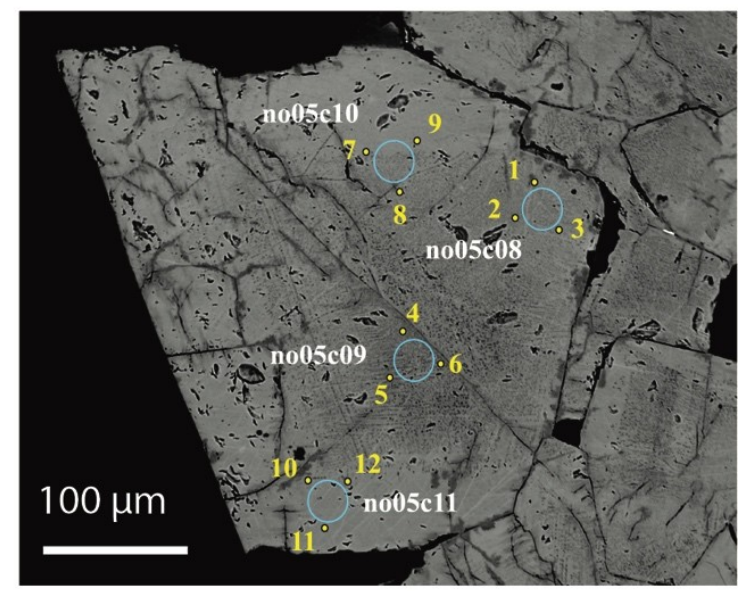

ELL-14-05 (3)

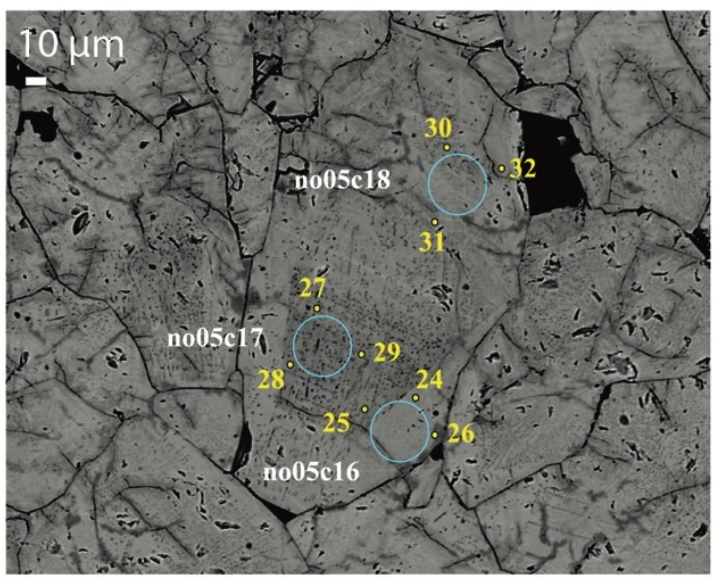

ELL-14-05 (5)

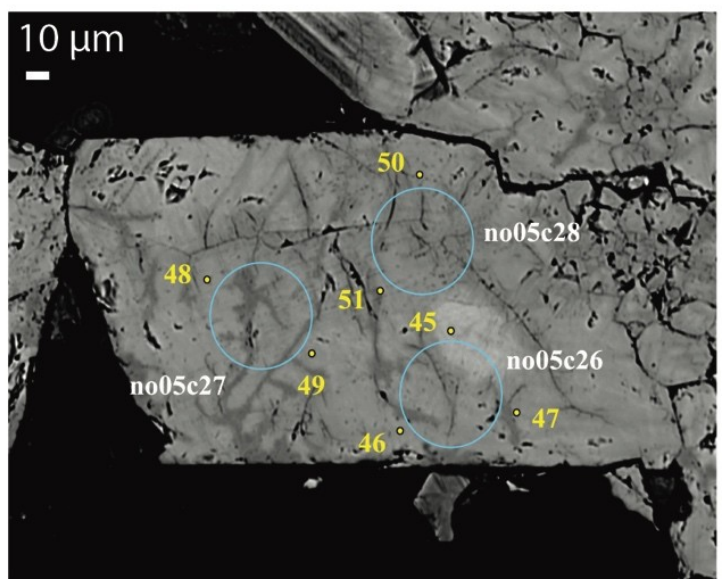


Appendix VI. (Cont.)

ELL-14-06 map

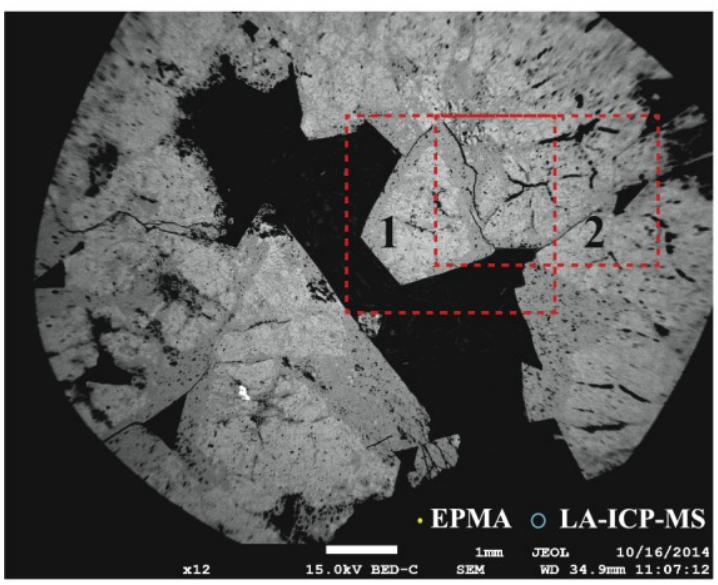

ELL-14-06 (2)

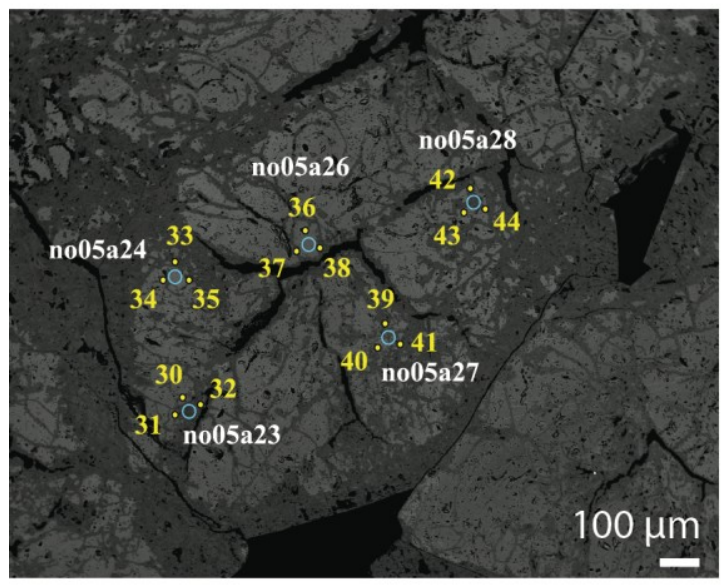

ELL-14-06 (1)

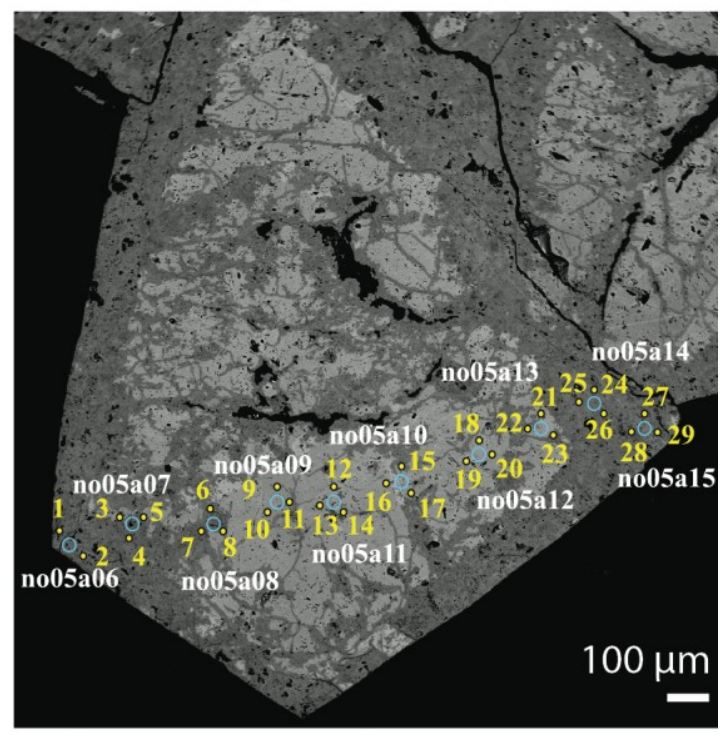

ELL-14-06 (3)

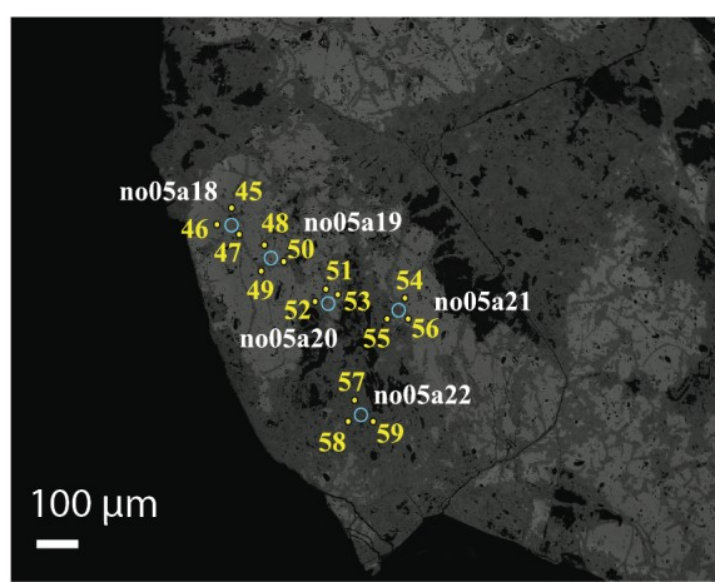


Appendix VI. (Cont.)

LAS-14-07 map

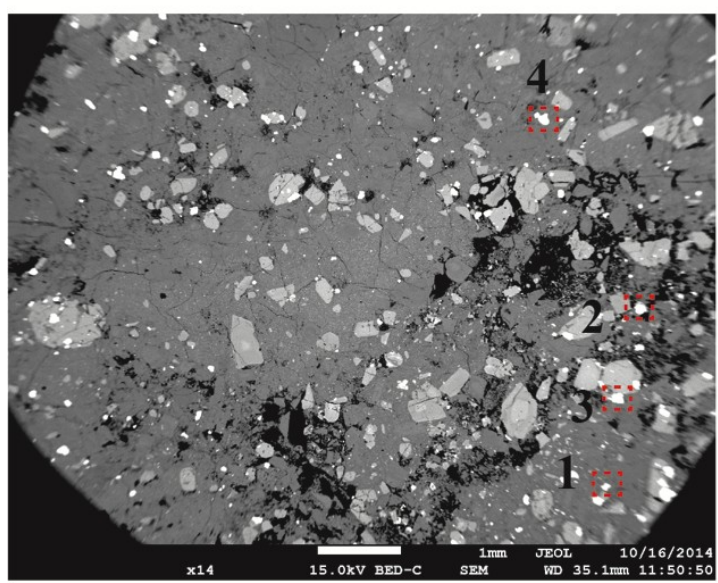

LAS-14-07 (2)

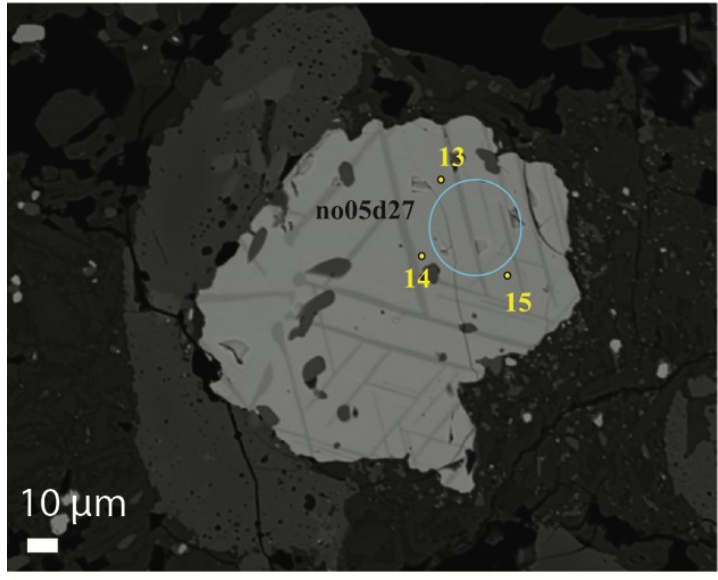

LAS-14-07 (4)

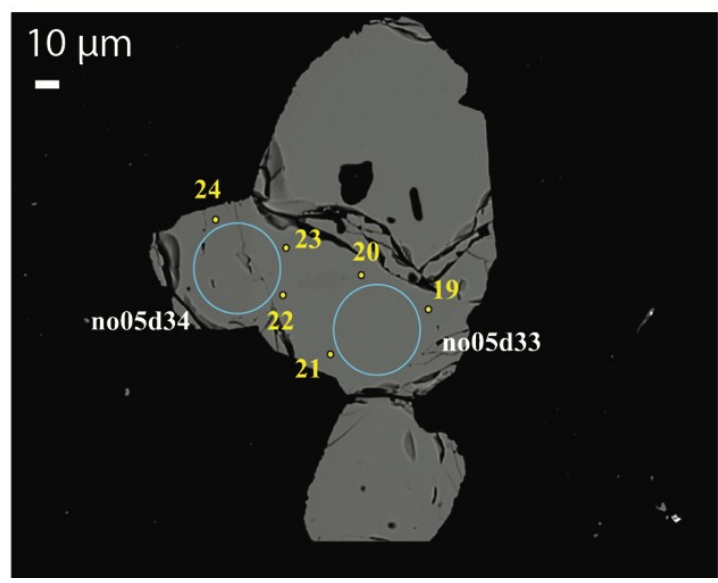

LAS-14-07 (1)

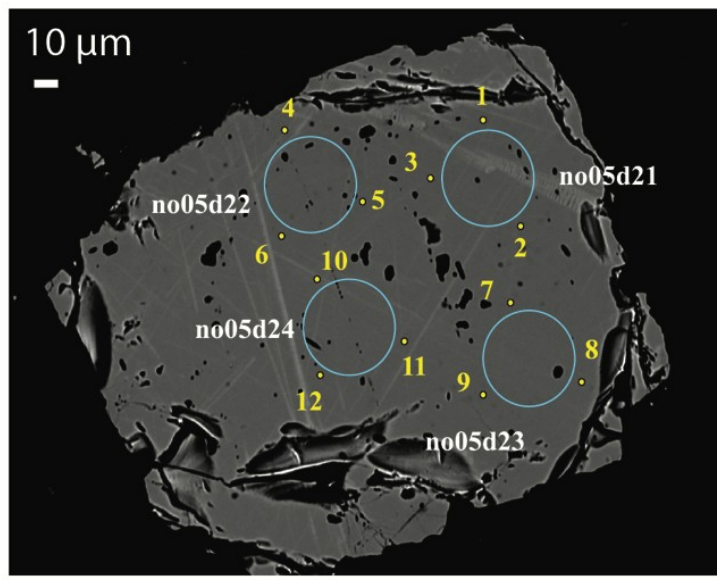

LAS-14-07 (3)

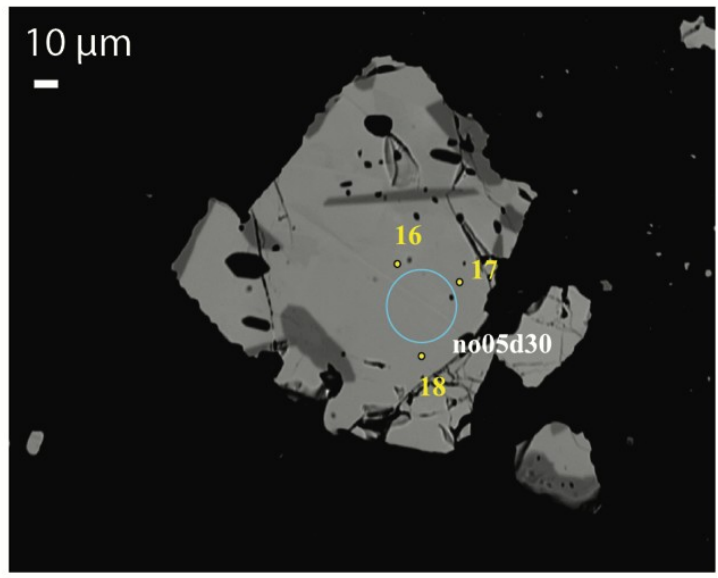


Appendix VII. LA-ICPMS spot analysis results for Mud Tank, Balmat and Bushveld magnetite. Fe (wt\%) is the mean concentrations of three or less EPMA analyses in the vicinity of LA-ICPMS spots.

\begin{tabular}{|c|c|c|c|c|c|c|c|c|c|c|c|c|c|c|c|c|}
\hline Sample & Rock Type & $\begin{array}{l}\text { Fe wt.\% } \\
\text { (EPMA) }\end{array}$ & ${ }^{24} \mathrm{Mg}$ & ${ }^{27} \mathrm{Al}$ & ${ }^{29} \mathrm{Si}$ & ${ }^{31} \mathrm{P}$ & ${ }^{34} \mathrm{~S}$ & ${ }^{44} \mathrm{Ca}$ & ${ }^{47} \mathrm{Ti}$ & ${ }^{51} \mathrm{~V}$ & ${ }^{52} \mathrm{Cr}$ & ${ }^{55} \mathrm{Mn}$ & ${ }^{59} \mathrm{Co}$ & ${ }^{60} \mathrm{Ni}$ & ${ }^{63} \mathrm{Cu}$ & ${ }^{66} \mathrm{Zn}$ \\
\hline \multirow{15}{*}{ Mudtank } & Carbonatite & & & & & & & & & & & & & & & \\
\hline & Mag & 68 & 1017 & 789 & 980 & 47 & 550 & & 2109 & 14170 & 193 & 276 & 124 & 657 & 4.4 & 407 \\
\hline & & 68 & 966 & 760 & 280 & 35 & 90 & & 2194 & 13960 & 87 & 289 & 123 & 664 & 11.5 & 365 \\
\hline & & 68 & 1002 & 699 & 240 & 7 & 100 & & 2213 & 13890 & 137 & 277 & 121 & 615 & 0.21 & 377 \\
\hline & & 68 & 962 & 716 & 230 & 10 & 450 & 100 & 2245 & 13710 & 94 & 276 & 118 & 611 & & 358 \\
\hline & & 68 & 941 & 737 & 230 & 14 & 290 & & 2229 & 13700 & 71 & 273 & 124 & 655 & 3.1 & 397 \\
\hline & & 68 & 901 & 708 & 1220 & 19 & 840 & & 2098 & 13740 & 168 & 260 & 121 & 630 & 1.8 & 376 \\
\hline & & 68 & 907 & 657 & 160 & & 640 & & 1789 & 13450 & 83 & 242 & 119 & 624 & & 331 \\
\hline & & 68 & 915 & 714 & 790 & 8.4 & 560 & 40 & 2017 & 13730 & 156 & 252 & 118 & 623 & & 354 \\
\hline & & 67 & 1138 & 672 & 530 & 9 & 420 & 100 & 3690 & 12640 & 112 & 426 & 117 & 606 & & 408 \\
\hline & & 68 & 1162 & 713 & 20 & 4 & 250 & 10 & 4760 & 13130 & 45 & 455 & 120 & 617 & 0.05 & 406 \\
\hline & & 67 & 1136 & 727 & 940 & & 250 & & 3662 & 13170 & 202 & 416 & 125 & 647 & & 512 \\
\hline & & 67 & 1096 & 688 & 110 & 24 & 210 & & 3310 & 13240 & 83 & 381 & 122 & 635 & & 475 \\
\hline & & 67 & 1100 & 724 & 610 & 8 & 520 & 140 & 3470 & 13120 & 94 & 401 & 123 & 637 & & 551 \\
\hline & & 68 & 44.1 & & 340 & 20 & 400 & 220 & 80 & 548 & 123 & 373 & 17 & & & 25060 \\
\hline \multirow[t]{6}{*}{ Balmat } & MVT Zn & 69 & 70 & & 710 & 19 & 370 & 140 & 65 & 594 & 134 & 350 & 19 & & & 23480 \\
\hline & Vein Mag & 68 & 40 & & 240 & 10 & 180 & 140 & 45 & 592 & 57 & 353 & 18 & & & 24850 \\
\hline & & 68 & 47 & & 230 & 7.9 & 230 & & 34 & 638 & 89 & 289 & 17 & & & 22820 \\
\hline & & 69 & 37 & & 1330 & 26 & 830 & 120 & 48 & 593 & 216 & 251 & 17 & & & 22570 \\
\hline & & 69 & 44 & & 140 & 2 & 20 & & 45 & 635 & 33 & 304 & 18 & & & 23700 \\
\hline & & 69 & 33 & & 1040 & 15 & 860 & 90 & 2 & 288 & 158 & 217 & 16 & & & 20980 \\
\hline
\end{tabular}


Appendix VII. (Cont.)

\begin{tabular}{|c|c|c|c|c|c|c|c|c|c|c|c|c|c|c|c|c|}
\hline Sample & Rock Type & $\begin{array}{l}\text { Fe wt.\% } \\
\text { (EPMA) }\end{array}$ & ${ }^{24} \mathrm{Mg}$ & ${ }^{27} \mathrm{Al}$ & ${ }^{29} \mathrm{Si}$ & ${ }^{31} \mathrm{P}$ & ${ }^{34} \mathrm{~S}$ & ${ }^{44} \mathrm{Ca}$ & ${ }^{47} \mathrm{Ti}$ & ${ }^{51} \mathrm{~V}$ & ${ }^{52} \mathrm{Cr}$ & ${ }^{55} \mathrm{Mn}$ & ${ }^{59} \mathrm{Co}$ & ${ }^{60} \mathrm{Ni}$ & ${ }^{63} \mathrm{Cu}$ & ${ }^{66} \mathrm{Zn}$ \\
\hline \multirow[t]{6}{*}{ Balmat } & MVT Zn Vein & 68 & 46 & & 820 & 6 & 700 & 200 & 64 & 443 & 84 & 615 & 21 & & & 27890 \\
\hline & Mag & 69 & 44 & & 310 & 16 & 510 & 70 & 12 & 4 & & 435 & 22 & & & 25420 \\
\hline & & 69 & 50 & & 80 & 12 & 260 & & 54 & 372 & 70 & 549 & 20 & & & 27090 \\
\hline & & 69 & 750 & 91 & 1920 & 27 & 490 & 190 & 23 & 220 & 267 & 434 & 20 & & & 22820 \\
\hline & & 69 & 44 & & 970 & 26 & 350 & 140 & 17 & 280 & 185 & 445 & 19 & & & 22480 \\
\hline & & 69 & 198 & & 1120 & 23 & 280 & 30 & 37 & 289 & 199 & 456 & 20 & & & 24240 \\
\hline \multirow{14}{*}{$\begin{array}{l}\text { Bushveld } \\
\text { (BC-28) }\end{array}$} & layered mafic & 57 & 6770 & 9100 & 3200 & 84 & 1960 & 290 & 70000 & 10530 & 1458 & 2381 & 182 & 326 & 99 & 262 \\
\hline & intrusion Mag & 58 & 5280 & 9430 & 200 & 188 & 600 & 130 & 85900 & 14280 & 1670 & 2690 & 230 & 318 & 477 & 307 \\
\hline & & 57 & 7770 & 4810 & 1360 & 21 & 1860 & 220 & 69100 & 9760 & 1498 & 2395 & 180 & 458 & 72 & 193 \\
\hline & & 57 & 6650 & 4980 & 1800 & 14 & 2260 & 320 & 75600 & 11730 & 1660 & 2540 & 178 & 261 & 89 & 242 \\
\hline & & 58 & 7930 & 5220 & & 35 & 1930 & & 74600 & 11210 & 1282 & 2717 & 394 & 112 & 102 & 268 \\
\hline & & 57 & 7230 & 4920 & 1660 & 9 & 1580 & 100 & 73100 & 10110 & 1494 & 2423 & 105 & 395 & 175 & 214 \\
\hline & & 57 & 5050 & 4500 & 2170 & 31 & 810 & 30 & 73100 & 10430 & 1396 & 2362 & 193 & 389 & 101 & 150 \\
\hline & & 57 & 5140 & 5550 & 4180 & 65 & 1010 & & 73600 & 11610 & 1502 & 2605 & 166 & 326 & 5 & 287 \\
\hline & & 58 & 11020 & 21140 & 1250 & 18 & 590 & & 64900 & 8410 & 1277 & 1986 & 290 & 572 & & 475 \\
\hline & & 56 & 10490 & 20910 & 120 & 15 & 320 & & 63500 & 8430 & 1237 & 1959 & 286 & 549 & & 451 \\
\hline & & 57 & 10380 & 19030 & 390 & 7 & 300 & & 66800 & 8820 & 1274 & 2312 & 307 & 596 & 10 & 425 \\
\hline & & 58 & 9870 & 20030 & 330 & 15 & 180 & & 67390 & 8680 & 1355 & 2318 & 309 & 578 & & 460 \\
\hline & & 57 & 11050 & 23320 & 130 & 19 & 230 & & 64700 & 8600 & 1312 & 2182 & 297 & 567 & 0 & 540 \\
\hline & & 57 & 9820 & 19170 & 590 & 20 & 170 & 70 & 66890 & 8950 & 1313 & 2306 & 290 & 570 & 7 & 443 \\
\hline
\end{tabular}


Appendix VII. (Cont.)

\begin{tabular}{|c|c|c|c|c|c|c|c|c|c|c|c|c|c|c|}
\hline Sample & Rock Type & ${ }^{71} \mathrm{Ga}$ & ${ }^{75} \mathrm{As}$ & ${ }^{88} \mathrm{Sr}$ & ${ }^{89} \mathrm{Y}$ & ${ }^{93} \mathrm{Nb}$ & ${ }^{118} \mathrm{Sn}$ & ${ }^{139} \mathrm{La}$ & ${ }^{140} \mathrm{Ce}$ & ${ }^{141} \mathrm{Pr}$ & ${ }^{146} \mathrm{Nd}$ & ${ }^{147} \mathrm{Sm}$ & ${ }^{153} \mathrm{Eu}$ & ${ }^{157} \mathrm{Gd}$ \\
\hline \multirow{14}{*}{ Mudtank } & Carbonatite & & & & & & & & & & & & & \\
\hline & Mag & 28 & 0.82 & 0.86 & 0.14 & 0.15 & 7 & 0.41 & 1.43 & 0.04 & 0.31 & 0.03 & 0.07 & 0.33 \\
\hline & & 26 & 0.07 & 2.40 & 0.16 & 0.11 & 7 & 0.34 & 0.55 & 0.07 & 0.13 & 0.01 & 0.08 & 0.36 \\
\hline & & 26 & 0.16 & 0.03 & 0.06 & 0.01 & 7 & 0.07 & 0.14 & 0.06 & 0.01 & & 0.02 & 0.35 \\
\hline & & 26 & & 1.10 & 0.01 & 0.09 & 7 & 0.04 & 0.11 & 0.02 & 0.10 & 0.02 & 0.06 & 0.40 \\
\hline & & 28 & 0.05 & 1.70 & 0.16 & 0.31 & 8 & 0.47 & 0.49 & 0.13 & 0.11 & 0.06 & 0.04 & 0.56 \\
\hline & & 26 & 0.13 & 0.60 & 0.11 & 1.32 & 8 & 0.34 & 0.38 & 0.05 & 0.13 & 0.01 & 0.02 & 0.56 \\
\hline & & 26 & & 0.45 & 0.03 & & 7 & 0.10 & 0.18 & 0.06 & 0.03 & 0.09 & 0.07 & 0.52 \\
\hline & & 27 & 0.01 & & & 0.01 & 7 & 0.12 & 0.07 & 0.01 & 0.15 & 0.10 & 0.07 & 0.25 \\
\hline & & 25 & 0.12 & & 0.06 & 0.03 & 10 & 0.02 & 0.04 & 0.02 & 0.02 & 0.02 & 0.03 & 0.03 \\
\hline & & 26 & 0.00 & & 0.04 & 0.04 & 10 & 0.04 & 0.02 & 0.03 & 0.04 & 0.01 & 0.03 & \\
\hline & & 27 & 0.42 & 0.09 & 0.08 & 0.03 & 10 & 0.04 & 0.00 & 0.02 & 0.01 & 0.02 & 0.05 & 0.22 \\
\hline & & 27 & 0.24 & 0.09 & 0.02 & 0.02 & 9 & 0.01 & 0.06 & 0.02 & 0.05 & 0.02 & 0.03 & \\
\hline & & 27 & & & & 0.03 & 9 & & 0.01 & 0.02 & 0.03 & & 0.03 & \\
\hline \multirow[t]{7}{*}{ Balmat } & MVT Zn Vein & 47 & 0.26 & 0.08 & 0.02 & 0.09 & 64 & 0.04 & 0.01 & & 0.03 & 0.03 & 0.03 & 0.08 \\
\hline & Mag & 47 & 2.28 & 0.20 & 0.02 & 0.05 & 61 & 0.08 & 0.02 & 0.02 & 0.05 & & 0.01 & 0.16 \\
\hline & & 46 & 0.07 & 0.04 & 0.09 & 0.03 & 65 & 0.07 & 0.04 & 0.05 & 0.18 & 0.01 & 0.02 & 0.08 \\
\hline & & 35 & 0.60 & 0.05 & 0.04 & 0.02 & 71 & 0.08 & 0.06 & 0.01 & 0.09 & 0.03 & 0.03 & 0.35 \\
\hline & & 36 & 0.51 & 0.13 & 0.06 & 0.05 & 70 & 0.07 & 0.00 & 0.03 & 0.15 & 0.01 & 0.02 & 0.35 \\
\hline & & 34 & 0.62 & & 0.05 & 0.08 & 71 & 0.06 & 0.00 & 0.03 & & 0.01 & 0.03 & 0.54 \\
\hline & & 32 & 1.11 & 0.02 & 0.02 & 0.09 & 46 & 0.05 & 0.01 & 0.00 & 0.03 & 0.47 & 0.03 & 0.27 \\
\hline
\end{tabular}




\section{Appendix VII. (Cont.)}

\begin{tabular}{|c|c|c|c|c|c|c|c|c|c|c|c|c|c|c|}
\hline Sample & Rock Type & ${ }^{71} \mathrm{Ga}$ & ${ }^{75} \mathrm{As}$ & ${ }^{88} \mathrm{Sr}$ & ${ }^{89} \mathrm{Y}$ & ${ }^{93} \mathrm{Nb}$ & ${ }^{118} \mathrm{Sn}$ & ${ }^{139} \mathrm{La}$ & ${ }^{140} \mathrm{Ce}$ & ${ }^{141} \operatorname{Pr}$ & ${ }^{146} \mathrm{Nd}$ & ${ }^{147} \mathrm{Sm}$ & ${ }^{153} \mathrm{Eu}$ & ${ }^{157} \mathrm{Gd}$ \\
\hline \multirow{7}{*}{ Balmat } & MVT Zn Vein & & & & & & & & & & & & & \\
\hline & Mag & 31 & 3.33 & & 0.06 & 0.05 & 63 & 0.03 & 0.07 & 0.02 & 0.01 & 0.00 & 0.08 & \\
\hline & & 19 & 0.59 & & 0.08 & 0.05 & 7 & 0.05 & 0.03 & 0.07 & 0.02 & & 0.02 & \\
\hline & & 36 & 0.12 & 0.90 & 0.03 & 0.02 & 53 & 0.02 & 0.02 & 0.04 & 0.09 & & 0.08 & \\
\hline & & 53 & 3.16 & 0.41 & & 0.05 & 46 & 0.06 & 0.03 & 0.01 & & 0.05 & 0.02 & \\
\hline & & 44 & 0.43 & 0.16 & & 0.03 & 48 & 0.02 & 0.02 & 0.05 & 0.07 & & 0.04 & \\
\hline & & 49 & 3.78 & & & 0.04 & 51 & & 0.02 & 0.06 & 0.00 & 0.01 & 0.02 & \\
\hline \multirow{14}{*}{$\begin{array}{c}\text { Bushveld } \\
\text { (BC-28) }\end{array}$} & layered mafic & 52 & 0.09 & 2.93 & 0.17 & 1.29 & 2 & 0.20 & 0.12 & 0.09 & & & 0.02 & 0.33 \\
\hline & intrusion Mag & 68 & & 6.00 & 0.17 & 2.37 & 2 & 0.22 & 0.27 & 0.07 & & & 0.17 & 1.80 \\
\hline & & 54 & & 1.09 & 0.02 & 1.30 & 1 & 0.07 & 0.03 & 0.01 & & 0.02 & 0.03 & 0.44 \\
\hline & & 66 & & 2.16 & 0.02 & 1.69 & 2 & 0.09 & 0.20 & 0.04 & 0.05 & 0.06 & 0.07 & 0.77 \\
\hline & & 66 & & 3.23 & & 1.39 & 1 & 0.16 & 0.08 & 0.07 & 0.03 & 0.11 & 0.09 & 0.40 \\
\hline & & 65 & & 1.93 & 0.04 & 1.33 & 1 & 0.00 & 0.04 & 0.09 & 0.01 & 0.01 & 0.08 & 0.28 \\
\hline & & 51 & 0.21 & 1.19 & 0.02 & 1.52 & 2 & 0.05 & 0.05 & 0.02 & 0.03 & 0.13 & 0.02 & 0.04 \\
\hline & & 67 & & 2.93 & 0.11 & 1.47 & 2 & 0.16 & 0.27 & 0.04 & 0.23 & & 0.03 & 1.07 \\
\hline & & 47 & 0.25 & 1.40 & 0.08 & 1.05 & 2 & 0.02 & 0.01 & 0.04 & 0.07 & 0.01 & 0.02 & \\
\hline & & 47 & 0.15 & 3.60 & 0.03 & 1.01 & 2 & 0.36 & 0.12 & 0.06 & 0.02 & 0.02 & 0.04 & \\
\hline & & 48 & 0.11 & 0.37 & 0.07 & 0.92 & 2 & 0.08 & 0.04 & 0.04 & 0.09 & 0.02 & 0.03 & \\
\hline & & 48 & 0.07 & & 0.05 & 0.85 & 2 & 0.06 & 0.05 & 0.08 & 0.32 & & 0.02 & 0.12 \\
\hline & & 50 & 0.01 & 1.30 & 0.02 & 1.01 & 2 & 0.11 & 0.01 & 0.06 & 0.15 & 0.01 & 0.09 & 0.25 \\
\hline & & 49 & & 4.20 & 0.02 & 1.00 & 2 & 0.08 & 0.06 & 0.06 & 0.03 & 0.01 & 0.01 & 0.28 \\
\hline
\end{tabular}




\section{Appendix VII. (Cont.)}

\begin{tabular}{|c|c|c|c|c|c|c|c|c|c|c|c|c|c|c|c|}
\hline Sample & Rock Type & ${ }^{159} \mathrm{~Tb}$ & ${ }^{163}$ Dy & ${ }^{165} \mathrm{Ho}$ & ${ }^{166} \mathrm{Er}$ & ${ }^{169} \mathrm{Tm}$ & ${ }^{172} \mathrm{Yb}$ & ${ }^{175} \mathrm{Lu}$ & ${ }^{178} \mathrm{Hf}$ & ${ }^{181} \mathrm{Ta}$ & ${ }^{197} \mathrm{Au}$ & ${ }^{205} \mathrm{Tl}$ & ${ }^{208} \mathrm{~Pb}$ & ${ }^{232} \mathrm{Th}$ & ${ }^{238} \mathrm{U}$ \\
\hline \multirow[t]{13}{*}{ Mudtank } & Carbonatite Mag & 0.02 & 0.00 & 0.00 & 0.00 & 0.00 & 0.00 & & & 0.01 & & 0.01 & 0.71 & 0.06 & 0.04 \\
\hline & & 0.00 & 0.04 & 0.00 & 0.01 & 0.01 & & 0.02 & & 0.02 & & 0.00 & 0.56 & 0.05 & 0.05 \\
\hline & & 0.00 & 0.01 & 0.00 & 0.01 & 0.03 & 0.01 & & 0.01 & 0.01 & 0.05 & 0.01 & 0.06 & 0.11 & \\
\hline & & 0.00 & 0.04 & 0.00 & 0.00 & 0.01 & 0.00 & 0.01 & 0.01 & 0.00 & 0.02 & 0.01 & 0.11 & 0.12 & 0.00 \\
\hline & & 0.02 & 0.01 & 0.00 & 0.01 & 0.00 & 0.03 & 0.00 & 0.02 & 0.03 & 0.02 & & 0.50 & 0.00 & 0.07 \\
\hline & & 0.01 & 0.00 & 0.00 & 0.00 & 0.01 & 0.03 & 0.02 & 0.00 & 0.07 & & & 0.39 & 0.33 & 0.11 \\
\hline & & 0.00 & 0.01 & 0.00 & & 0.01 & 0.01 & 0.01 & 0.01 & 0.00 & & 0.01 & 0.06 & & \\
\hline & & 0.03 & 0.00 & 0.00 & 0.00 & 0.01 & 0.00 & 0.01 & 0.00 & 0.02 & & 0.01 & 0.09 & 0.02 & \\
\hline & & 0.00 & & 0.00 & 0.01 & 0.00 & 0.01 & 0.01 & 0.01 & 0.01 & 0.10 & & 0.04 & & 0.01 \\
\hline & & 0.03 & 0.00 & 0.00 & 0.01 & 0.01 & & 0.01 & 0.02 & 0.01 & & 0.00 & 0.03 & & \\
\hline & & 0.05 & 0.01 & 0.00 & 0.02 & 0.01 & 0.02 & 0.01 & & 0.02 & & 0.00 & 0.05 & & \\
\hline & & 0.02 & 0.01 & 0.01 & 0.01 & 0.01 & 0.02 & 0.01 & 0.01 & 0.03 & & 0.00 & 0.03 & 0.01 & \\
\hline & & 0.01 & & & 0.00 & 0.02 & 0.01 & 0.01 & 0.00 & 0.04 & & 0.00 & 0.04 & 0.00 & 0.00 \\
\hline \multirow[t]{7}{*}{ Balmat } & MVT Zn Vein & 0.00 & 0.01 & 0.00 & & 0.00 & & 0.00 & 0.00 & 0.02 & & & 0.09 & 0.01 & 0.00 \\
\hline & Mag & 0.02 & 0.01 & & & 0.01 & & 0.00 & 0.01 & 0.01 & 0.02 & 0.01 & 0.91 & 0.01 & \\
\hline & & 0.03 & 0.00 & 0.00 & & 0.01 & 0.01 & 0.00 & & 0.01 & & 0.00 & 0.06 & 0.26 & \\
\hline & & 0.02 & 0.02 & 0.00 & & 0.01 & 0.00 & 0.00 & 0.00 & 0.02 & & & 0.25 & 0.02 & 0.00 \\
\hline & & 0.01 & 0.01 & 0.00 & & & & 0.01 & 0.00 & 0.01 & & & 0.09 & & \\
\hline & & 0.01 & 0.01 & & 0.08 & & 0.03 & & & 0.02 & 0.06 & & 0.05 & 0.00 & \\
\hline & & 0.01 & 0.01 & 0.01 & 0.00 & 0.00 & 0.03 & 0.01 & 0.01 & 0.02 & & 0.00 & 0.20 & 0.01 & \\
\hline
\end{tabular}




\section{Appendix VII. (Cont.)}

\begin{tabular}{|c|c|c|c|c|c|c|c|c|c|c|c|c|c|c|c|}
\hline Sample & Rock Type & ${ }^{159} \mathrm{~Tb}$ & ${ }^{163} \mathrm{Dy}$ & ${ }^{165} \mathrm{Ho}$ & ${ }^{166} \mathrm{Er}$ & ${ }^{169} \mathrm{Tm}$ & ${ }^{172} \mathrm{Yb}$ & ${ }^{175} \mathrm{Lu}$ & ${ }^{178} \mathrm{Hf}$ & ${ }^{181} \mathrm{Ta}$ & ${ }^{197} \mathrm{Au}$ & ${ }^{205} \mathrm{Tl}$ & ${ }^{208} \mathrm{~Pb}$ & ${ }^{232} \mathrm{Th}$ & ${ }^{238} \mathrm{U}$ \\
\hline \multirow[t]{6}{*}{ Balmat } & MVT Zn Vein & 0.01 & 0.03 & 0.00 & 0.00 & 0.00 & 0.00 & 0.01 & & 0.01 & 0.02 & 0.02 & 0.83 & & \\
\hline & Mag & 0.03 & & 0.00 & 0.01 & 0.02 & 0.00 & 0.00 & 0.01 & 0.01 & & 0.01 & 0.05 & & \\
\hline & & 0.01 & 0.02 & 0.00 & 0.00 & 0.01 & & 0.01 & 0.00 & 0.01 & & & 0.03 & 0.00 & 0.00 \\
\hline & & 0.02 & 0.00 & 0.00 & & 0.01 & 0.01 & 0.01 & & 0.02 & 0.02 & 0.01 & 0.46 & 0.02 & 0.00 \\
\hline & & 0.02 & 0.01 & 0.02 & 0.00 & 0.01 & 0.01 & 0.00 & & 0.01 & & & 0.05 & 0.01 & 0.00 \\
\hline & & 0.01 & & 0.00 & 0.01 & 0.00 & 0.02 & 0.01 & 0.00 & 0.02 & & 0.00 & 0.63 & 0.00 & 0.02 \\
\hline \multirow{14}{*}{$\begin{array}{c}\text { Bushveld } \\
\text { (BC-28) }\end{array}$} & layered mafic & & & 0.00 & & & 0.01 & & 0.03 & 0.04 & 0.28 & 0.08 & 0.91 & & \\
\hline & intrusion Mag & 0.01 & & 0.01 & 0.02 & 0.02 & 0.05 & 0.12 & 0.18 & 0.18 & 0.33 & 0.02 & 1.68 & & \\
\hline & & & & 0.01 & & 0.01 & 0.01 & & 0.14 & 0.15 & & 0.01 & 0.32 & & \\
\hline & & 0.05 & & 0.00 & 0.07 & 0.01 & & & 0.15 & 0.11 & 0.23 & 0.01 & 1.53 & & \\
\hline & & 0.02 & 0.05 & 0.03 & & 0.00 & 0.07 & 0.04 & 0.08 & 0.09 & & 0.02 & 0.51 & & 0.01 \\
\hline & & 0.01 & 0.01 & 0.00 & & 0.01 & 0.03 & 0.01 & 0.32 & 0.09 & & & 0.37 & & 0.00 \\
\hline & & & 0.02 & 0.00 & & 0.02 & 0.02 & 0.01 & 0.14 & 0.11 & & & 0.45 & & \\
\hline & & 0.03 & 0.03 & 0.02 & & 0.06 & 0.02 & 0.02 & 0.05 & 0.06 & & 0.01 & 1.17 & & \\
\hline & & 0.01 & 0.01 & 0.01 & 0.02 & 0.01 & & 0.01 & 0.47 & 0.08 & & 0.00 & 0.04 & 0.04 & 0.21 \\
\hline & & 0.02 & 0.02 & 0.00 & & 0.02 & 0.03 & 0.02 & 0.61 & 0.05 & & & 0.07 & 0.03 & 0.02 \\
\hline & & 0.01 & 0.02 & 0.00 & 0.00 & 0.00 & 0.06 & 0.01 & 0.47 & 0.09 & & & 0.06 & 0.18 & 0.00 \\
\hline & & 0.02 & 0.02 & 0.00 & 0.01 & 0.01 & & 0.01 & 0.63 & 0.07 & & & 0.02 & 0.00 & 0.00 \\
\hline & & 0.02 & 0.01 & 0.01 & & 0.00 & 0.04 & 0.02 & 0.41 & 0.08 & & 0.00 & 0.07 & 0.02 & 0.01 \\
\hline & & 0.00 & 0.04 & 0.02 & 0.01 & 0.01 & 0.01 & 0.01 & 0.53 & 0.05 & & & 0.10 & 0.05 & \\
\hline
\end{tabular}


Appendix VIII. LA-ICPMS spot analysis results (ppm) for BCR-2G glass during the Kiruna and El Laco analyses.

\begin{tabular}{|c|c|c|c|c|c|c|c|}
\hline Element & Kiruna & E1 Laco & MUN Long term & Element & Kiruna & El Laco & MUN Long term \\
\hline${ }^{24} \mathrm{Mg}$ & 19662 & 22984 & 17318 & ${ }^{140} \mathrm{Ce}$ & 47.3 & & 51.2 \\
\hline${ }^{29} \mathrm{Si}$ & $2.55 \mathrm{E}+05$ & $2.89 \mathrm{E}+05$ & $2.54 \mathrm{E}+05$ & ${ }^{141} \operatorname{Pr}$ & 5.73 & & 6.44 \\
\hline${ }^{31} \mathrm{P}$ & 1175 & 1316 & 643.99 & ${ }^{146} \mathrm{Nd}$ & 24.9 & & 27.8 \\
\hline${ }^{44} \mathrm{Ca}$ & 45972 & 54324 & 42317 & ${ }^{147} \mathrm{Sm}$ & 5.75 & & 6.30 \\
\hline${ }^{47} \mathrm{Ti}$ & 12021 & 13740 & 35.58 & ${ }^{153} \mathrm{Eu}$ & 1.79 & & 1.87 \\
\hline${ }^{51} \mathrm{~V}$ & 405 & 457 & 15714 & ${ }^{157} \mathrm{Gd}$ & 5.78 & & 6.24 \\
\hline${ }^{52} \mathrm{Cr}$ & 32.2 & 21.7 & 408 & ${ }^{159} \mathrm{~Tb}$ & 0.90 & & 0.94 \\
\hline${ }^{55} \mathrm{Mn}$ & 1586 & 1815 & & ${ }^{163} \mathrm{Dy}$ & 5.43 & & 6.10 \\
\hline${ }^{59} \mathrm{Co}$ & 37.1 & 42.3 & 1825 & ${ }^{165} \mathrm{Ho}$ & 1.13 & & 1.23 \\
\hline${ }^{60} \mathrm{Ni}$ & 5.88 & 18.5 & 36.0 & ${ }^{166} \mathrm{Er}$ & 2.99 & & 3.43 \\
\hline${ }^{63} \mathrm{Cu}$ & 17.1 & 19.3 & 12.0 & ${ }^{169} \mathrm{Tm}$ & 0.44 & & 0.49 \\
\hline${ }^{66} \mathrm{Zn}$ & 131 & 153 & 26.0 & ${ }^{172} \mathrm{Yb}$ & 2.85 & & 3.38 \\
\hline${ }^{75} \mathrm{As}$ & 1.10 & 1.06 & 156 & ${ }^{175} \mathrm{Lu}$ & 0.43 & & 0.48 \\
\hline${ }^{88} \mathrm{Sr}$ & 304 & 360 & & ${ }^{178} \mathrm{Hf}$ & 4.35 & & 4.57 \\
\hline${ }^{89} \mathrm{Y}$ & 28.8 & 35.4 & 326 & ${ }^{181} \mathrm{Ta}$ & 0.67 & 0.76 & 0.76 \\
\hline${ }^{93} \mathrm{Nb}$ & 9.98 & 11.8 & 32.3 & ${ }^{197} \mathrm{Au}$ & 0.58 & & \\
\hline${ }^{118} \mathrm{Sn}$ & 2.02 & 2.00 & 12.0 & ${ }^{208} \mathrm{~Pb}$ & 9.94 & 10.9 & 11.4 \\
\hline${ }^{138} \mathrm{Ba}$ & & 694 & & ${ }^{232} \mathrm{Th}$ & 5.31 & 6.39 & 5.80 \\
\hline${ }^{139} \mathrm{La}$ & 23.2 & & 24.6 & ${ }^{238} \mathrm{U}$ & 1.65 & & 1.62 \\
\hline
\end{tabular}

